
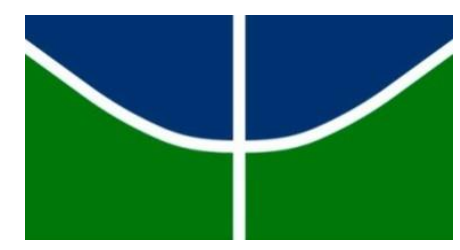

Universidade de Brasília

Departamento de Línguas Estrangeiras e Tradução

Programa de Pós-Graduação em Linguística Aplicada

\author{
LÍGIA SOARES SENE
}

\title{
OBJETIVOS E MATERIALIDADES DO ENSINO DE PORTUGUÊS COMO LÍNGUA DE ACOLHIMENTO: UM ESTUDO DE CASO
}

Dissertação de mestrado apresentada ao Programa de Pós-Graduação em Linguística Aplicada, Departamento de Línguas Estrangeiras e Tradução, Instituto de Letras, Universidade de Brasília, como requisito parcial à obtenção do título de Mestre em Linguística Aplicada, Área de concentração Língua e Cultura na Competência Comunicativa.

ORIENTADORA: Profa. Dra. Lucia Maria de Assunção Barbosa

Brasília 


\section{LÍGIA SOARES SENE}

\section{OBJETIVOS E MATERIALIDADES DO ENSINO DE PORTUGUÊS COMO LÍNGUA DE ACOLHIMENTO: UM ESTUDO DE CASO}

Dissertação de mestrado apresentada ao Programa de Pós-Graduação em Linguística Aplicada, Departamento de Línguas Estrangeiras e Tradução, Instituto de Letras, Universidade de Brasília, como requisito parcial à obtenção do título de Mestre em Linguística Aplicada, Área de concentração Língua e Cultura na Competência Comunicativa.

ORIENTADORA: Profa. Dra. Lucia Maria de Assunção Barbosa 


\section{OBJETIVOS E MATERIALIDADES DO ENSINO DE PORTUGUÊS COMO LÍNGUA DE ACOLHIMENTO: UM ESTUDO DE CASO}

Dissertação de mestrado apresentada ao Programa de Pós-Graduação em Linguística Aplicada, Departamento de Línguas Estrangeiras e Tradução, Instituto de Letras, Universidade de Brasília, como requisito parcial à obtenção do título de Mestre em Linguística Aplicada, Área de concentração Língua e Cultura na Competência Comunicativa

Aprovada por:

Profa. Dra. Lucia Maria de Assunção Barbosa - Universidade de Brasília (Orientadora)

Profa. Dra. Rosane de Sá Amado - Universidade de São Paulo (Examinador Externo)

Prof. Dr. Augusto César Luitgards Moura Filho - Universidade de Brasília (Examinador Interno)

Profa. Dra. Mirelle Amaral de São Bernardo - Instituto Federal Goiano (Examinador Suplente) 
Dedico a todo(a)s aquele(a)s que deixam suas terras, seus afetos, em busca de vida, de paz, de sonhos e de amor. 


\section{AGRADECIMENTOS}

Agradeço à minha fonte eterna de inspiração e amor, meus pais Maria Lúcia e Valter. Aos meus queridos irmãos e irmãs. Aos meus pequenos anjos Gabriela e João Pedro. À minha amada avó Lourdes pelo exemplo de força. Ao meu nego, Danilo, pelo amor e incentivo.

À minha estimada orientadora Profa. Dra. Lucia Barbosa pelo acolhimento, incentivo, aprendizagens, oportunidade e confiança. Muitíssimo obrigada!

A todo(a)s meus/minhas aprendentes por terem me ensinado tanto ao longo dessa caminhada no Módulo Acolhimento.

À Coordenação de Aperfeiçoamento de Pessoal de Nível Superior (CAPES) pela concessão de bolsa de estudo.

A todos do IMDH, especificamente à Irmã Rosita, pela oportunidade de viver intensamente os dias nesse Instituto, obtendo experiências incríveis.

Ao grupo Demonstre Amor Amando, sobretudo à Maria Carolina Sayão e sua família por todo o carinho, disponibilidade e amor.

A toda a equipe do Módulo Acolhimento e a todo(a)s o(a)s professore(a)s, coordenadora e secretário(a)s do NEPPE, especificamente à Alice Piauilino pela amável recepção e pela alegria diária.

À escola Coup de Pouce pela experiência de acolhimento como imigrante, que influenciou (in) diretamente na motivação de realizar esse trabalho.

Aos professores do PGLA, à secretaria e aos colegas de curso. De maneira especial, ao professor Dr. Augusto César Luitgards Moura Filho pela atenção dispensada a este trabalho e pelas discussões riquíssimas sobre ele.

À Mirelle Amaral, Veronica Gonzalez e Giuliano Castro pelas conversas enriquecedoras que iluminaram esse trabalho. 
À professora Rosane Sá Amado por ter aceitado o convite para esta banca. À professora Ana Lúcia Silva Souza pela contribuição durante a qualificação.

À minha amada amiga Ingrid pela força, pelas descobertas, pela companhia diária, pelos risotos, pelos cafés e açaís, pelas buzanisses, pelas risadas e por todo o amor.

Ao meu passarinho luz, Marco Nagoa, por toda caminhada, parceria, viagens, leituras e abraços de amor.

À minha mais animada amiga, Natalia Rangel, por toda a ajuda, toda companhia e pela sincera amizade.

Ao querido amigo Rogério, pela amizade, por todos os queijos e doces e por me receber com tanto cuidado e amor em Brasília.

Às minhas amigas Paula, Julia, Luísa e Priscila por terem me acolhido em Brasília, tornando os meus dias nessa cidade ainda mais felizes e divertidos.

Ao meu amigo Ananji por todo o cuidado, por todas as gentilezas e divertida companhia.

À minha poeta Ana Teresa pelo incentivo, pela paciência, pela companhia, pelas poesias no riso e no corpo, por toda ternura.

Aos meus querido(a)s amigo(a)s Francano(a)s e Uberlandensses que sempre me trazem vida e muitas alegrias. 


\section{AUTOTOMIA}

Em perigo, a holotúria se divide em duas: com uma sua metade se entrega à voracidade do mundo, com a outra foge.

Desintegra-se violentamente em ruína e salvação, em multa e prêmio, no que foi e no que será.

No meio do corpo da holotúria se abre um abismo com duas margens subitamente estranhas.

Em uma margem a morte, na outra a vida. Aqui o desespero, lá o alento

Se existe balança, os pratos não oscilam.

Se existe justiça, é esta.

Morrer só o necessário, sem exceder a medida. Regenerar quanto for preciso da parte que restou.

Também nós, é verdade, sabemos nos dividir. Mas somente em corpo e sussurros interrompido Em corpo e poesia.

De um lado a garganta, do outro o riso, leve, logo sufocado.

Aqui o coração pesado, lá non omnis moriar, três palavrinhas apenas como três penas em voo.

O abismo não nos divide. $\mathrm{O}$ abismo nos circunda.

Poema de Wislawa Szymborska 


\section{RESUMO}

Esta dissertação discorre sobre o conceito de Língua de Acolhimento, sobre as especificidades que envolvem esse ensino e sobre a composição de materialidades de ensino de língua de acordo com o modelo da Operação Global de Ensino de Línguas - OGEL. De acordo com esses conhecimentos e com a experiência docente que tive no âmbito da prática de ensino de português como Língua de Acolhimento (PLAc), a presente pesquisa teve por finalidade definir objetivos de ensino-aprendizagem dessa modalidade para uma turma de nível iniciante e, conforme essas experiências, reelaborar materialidades de ensino e analisar como tais práticas buscaram concretizar os objetivos propostos. Trata-se de um estudo de caso qualitativo, de cunho interpretativista, que apresenta objetivos de ensino de PLAc e analisa como a materialidade do material didático e dos procedimentos para experienciar a língua-alvo, destacando duas atividades nomeadas interculturais, foram desenvolvidos na turma de iniciantes (nomeada Acolher 1) do curso Módulo Acolhimento - Português para Refugiados e Imigrantes, ofertado pelo Núcleo de Ensino e Pesquisa em Português para Estrangeiros (NEPPE) da Universidade de Brasília. Para o desenvolvimento da pesquisa lancei mão dos seguintes instrumentos de coleta de dados: documentos (material didático reelaborado, textos produzidos pelos aprendentes da turma e registros de fotos); observação-participante; notas de campo e questionários mistos aplicados durante duas atividades realizadas ao longo do curso. Os resultados alcançados mostram que as materialidades analisadas buscaram efetivamente concretizar os objetivos do ensino, no entanto, em níveis diferenciados. O material didático auxiliou mais na aprendizagem e aquisição do português e no desenvolvimento de letramentos. As atividades interculturais propiciaram letramentos, interculturalidades e sentimento de acolhida. A pesquisa contou com o aporte teórico da linguística aplicada referente ao ensino de Língua Estrangeira e, especificamente, com referências ligadas ao ensino-aprendizagem da Língua de Acolhimento. Tendo em vista que, no Brasil, a especialidade de Português como Língua de Acolhimento tem, de maneira ainda incipiente, se desenvolvido e necessitado de olhares mais cuidados de profissionais da área de ensino-aprendizagem de línguas, essa pesquisa se torna relevante, uma vez que buscou promover discussões e compartilhar experiências de processos e práticas de ensino no âmbito do Português como Língua de Acolhimento.

Palavras-chave: Português como Língua de Acolhimento. Objetivos de ensino. Materialidades. 


\begin{abstract}
This dissertation discusses the concept of "host language" (Portuguese teaching for immigrants and refugees - PLAc in Portuguese initials), the specificities of this modality and the materialities of language teaching according to the model of Global Operation of Language Teaching. In reference to this knowledge and the experience I have had teaching Portuguese as host language, this research aimed to define goals for language learning in this context for beginner and, as a result, re-design classroom material in order to reach the objectives of the course. This research is a qualitative case study, using interpretive approach, which presents teaching objectives of PLAC and analyzes how the materiality of the didactic material and the procedures to experience the target language, highlighting two activities named as intercultural were developed and applied for beginner's group (called Hosting 1) in the course entitled Host Module - Portuguese for Refugees and Immigrants, offered in the Center of Education and Research in Portuguese for Foreigners of University of Brasília (Portuguese initials, NEPPE- UnB). The data collection instruments used were: documents (classroom material especially developed for the course, students' written activities and photos); participant observation; researcher notes and combined questionnaires applied during two activities developed throughout the course. The results show that the materialities analyzed tried to effectively reach the objectives of the course, but at different levels. The classroom material worked more effectively in the acquisition of the language and in literacy development. The intercultural activities provided literacy, intercultural communication and a welcoming feeling. This research has the theoretical contribution of the Applied Linguistics for foreign language acquisition, and, more specifically, to those related to "host language". Considering that teaching Portuguese as host language modality is still very new in Brazil, it needs a more professional and careful accountability from teachers, thus this research becomes relevant, since it promotes debates and shares experiences for the betterment of the area.
\end{abstract}

Key-words: Portuguese as "host language". Teaching objectives. Classroom materialities. 


\section{LISTA DE FIGURAS}

Figura 1 - Síntese do contexto e fatores do ensino-aprendizagem da língua de acolhimento, baseada nas colocações de Oliveira (2010) e Barbosa (2016) 35

Figura 2 - Síntese dos objetivos e motivações do público-aprendente em aprender

e adquirir a língua de acolhimento .37

Figura 3 - Modelo Ampliado da Operação Global do Ensino de Língua .............................39

Figura 4 - Objetivos do ensino-aprendizagem para a turma do Acolher 1 ........................... 81

Figura 5 - Exercícios estruturais - Módulo Apresentação ……............................................. 86

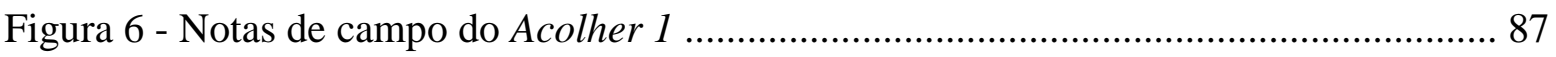

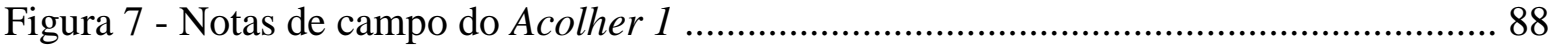

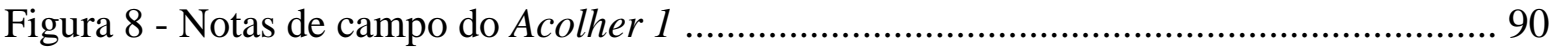

Figura 9 - Módulo Trabalho - textos dos aprendentes - Biografia ...................................... 91

Figura 10 - Módulo Trabalho - textos dos aprendentes - Anúncio e E-mail .........................96

Figura 11 - Módulo Trabalho - textos dos aprendentes - Curriculum Vitae .........................99

Figura 12 - Módulo Trabalho - textos dos aprendentes- Anúncio e E-mail ...........................102

Figura 13 - Planejamentos das Atividades Interculturais ...................................................105

Figura 14 - Registro Confraternização Chá\&Prosa .............................................................107

Figura 15 - Registro Confraternização Chá\&Prosa ............................................................... 110

Figura 16 - Registro Confraternização Chá\&Prosa ............................................................. 110

Figura 17 - Registro Confraternização Chá\&Prosa ............................................................. 110

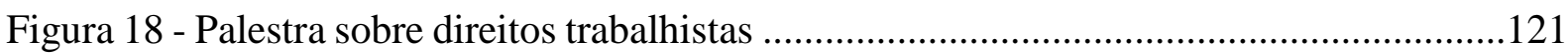

Figura 19 - Registro Elaboração do curriculum e portfólio - Desperta Profissional ............ 122

Figura 20 - Registro Elaboração do curriculum e portfólio - Desperta Profissional ............ 122 


\section{LISTA DE QUADROS}

Quadro 1 - Panorama da pesquisa: objetivo, perguntas, fonte de consulta, instrumentos de coleta e procedimento de análise .21

Quadro 2 - Resumo dos paradigmas de acordo com Laville \& Dionne (1999) .....................52

Quadro 3 - Razões da vinda para o Brasil......................................................................62

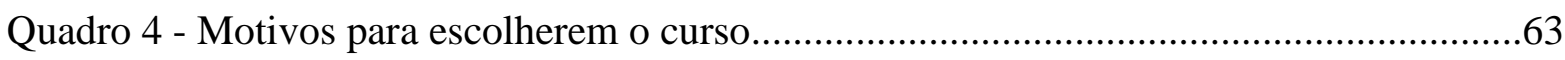

Quadro 5 - Objetivo após fazer o curso........................................................................63

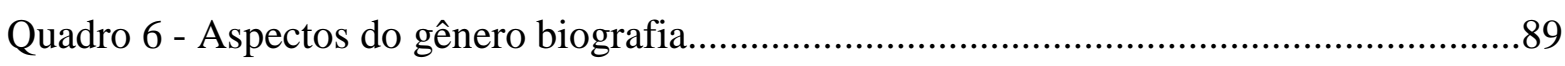

Quadro 7 - Aspectos do gênero anúncio e classificado.......................................................94

Quadro 8 - Aspectos do gênero e-mail..............................................................................95

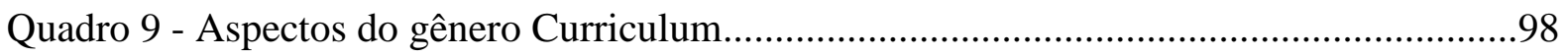

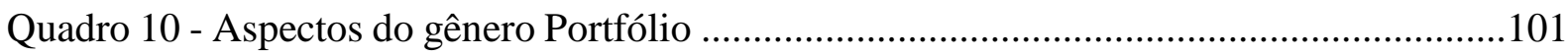

Quadro 11 - Respostas das questões de múltipla escolha - Chá \&Prosa .................................112

Quadro 12 - $1^{\text {a }}$ Categoria: Aprendizagem e aquisição de português........................................114

Quadro 13 - $2^{\text {a }}$ Categoria: Reconhecimento de letramento e aprendizagens............................115

Quadro 14 - $3^{\text {a }}$ Categoria: Efeitos e reflexões interculturais.................................................116

Quadro 15 - $4^{\text {a }}$ Categoria: Sentimento de acolhimento....................................................... 117

Quadro 16 - 5 Categoria: Percepções da atividade............................................................118

Quadro 17 - Respostas das questões de múltipla escolha - Despertar Profissional...............123

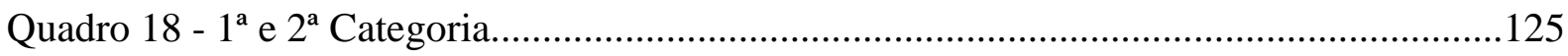

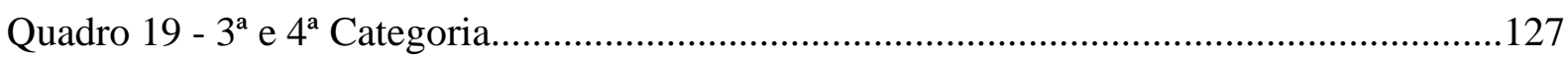

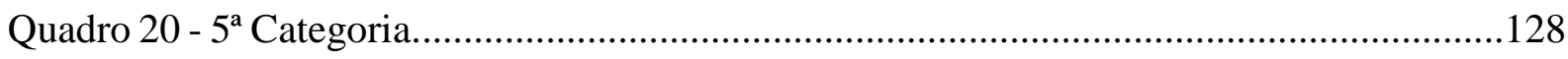




\section{LISTA DE GRÁFICOS}

Gráfico 1 - Nacionalidades da turma do Acolher 1 .........................................................61

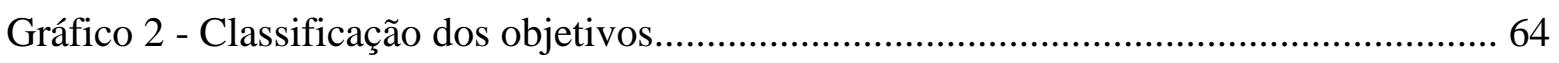

Gráfico 3 - Nacionalidades presentes no Chá\&Prosa ....................................................... 108

Gráfico 4 - Nacionalidades presentes no Despertar Profissional.........................................119 


\section{LISTA DE ABREVIATURAS E SIGLAS}

ACNUR - Alto Comissariado das Nações Unidas para Refugiados

CNIg - Conselho Nacional de Imigração

CONARE - Conselho Nacional para Refugiados

DF - Distrito Federal

DFTRANS - Transporte Urbano do Distrito Federal

FAP - Fundação de Apoio à Pesquisa do Distrito Federal

IMDH - Instituto Migrações e Direitos Humanos

L2 - Segunda Língua

LA - Linguística Aplicada

LE - Língua Estrangeira

NEPPE - Núcleo de Ensino e Pesquisa em Português para Estrangeiros

OBMigra - Observatório das Migrações Internacionais

PL2 - Português como Segunda Língua

PLA - Português como Língua Adicional

PLAc - Português como Língua de Acolhimento

PLE - Português como Língua Estrangeira

PLH - Português como Língua de Herança

PPGLA - Programa de Pós-Graduação em Linguística Aplicada

UnB - Universidade de Brasília 


\section{SUMÁRIO}

CAPÍTULO I: APRESENTAÇÃO DO ESTUDO..........................................................15

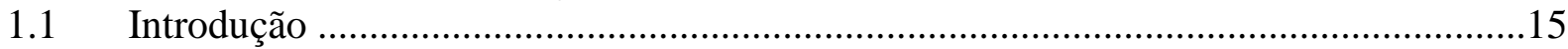

1.1.1 Breve panorama sobre imigração e refúgio no Brasil....................................................16

1.2 Justificativa e relevância da pesquisa ……………………..........................................19

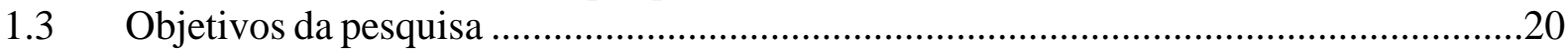

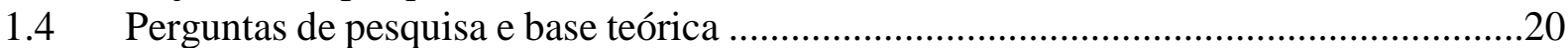

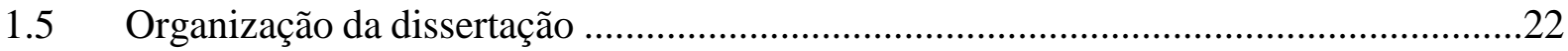

\section{CAPÍTULO II: FUNDAMENTAÇÃO TEÓRICA .....................................................23}

2.1 O ensino-aprendizagem de português como língua estrangeira (PLE) e suas

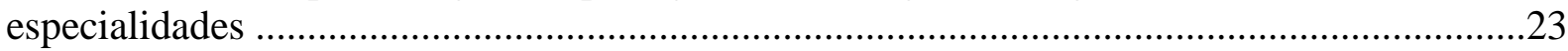

2.2 Português como língua de acolhimento.......................................................................26

2.2.1 Especificidades do ensino-aprendizagem de português para refugiados e

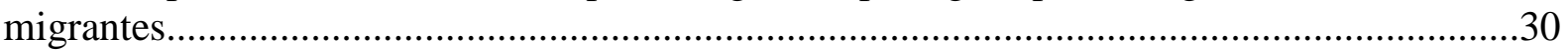

2.2.2 Síntese do contexto e dos fatores do ensino-aprendizagem de língua de

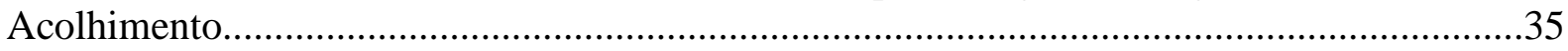

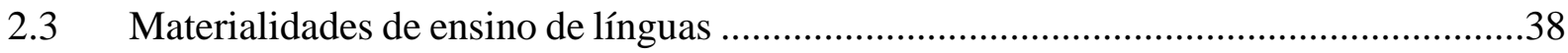

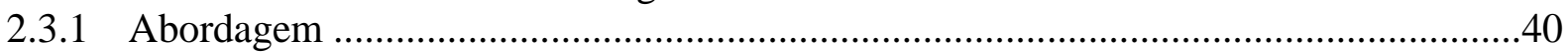

2.3.2 Planejamento de ensino …………………………............................................41

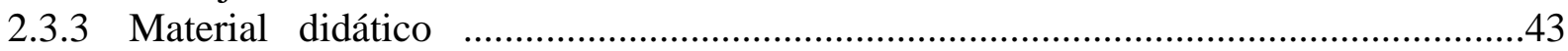

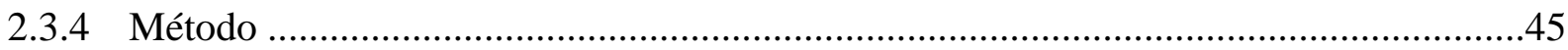

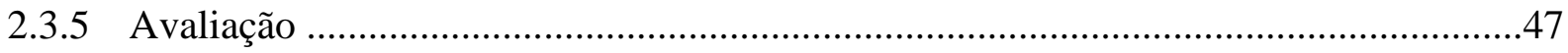

2.3.6 Formação docente do professor de português como língua estrangeira .........................48

CAPÍTULO III: METODOLOGIA DA PESQUISA .......................................................52

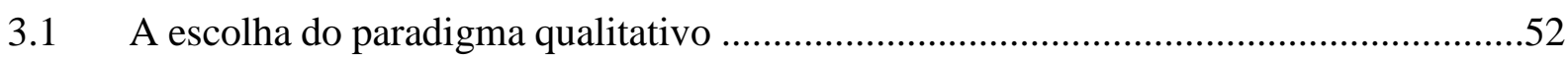

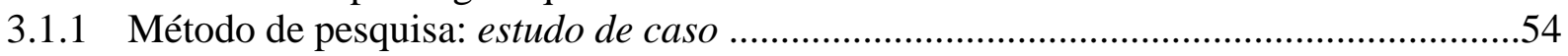

$3.2 \quad$ O contexto da pesquisa ...............................................................................................

3.2.1 O cenário da pesquisa Módulo Acolhimento: curso de português para

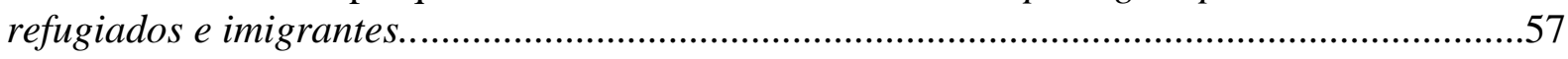

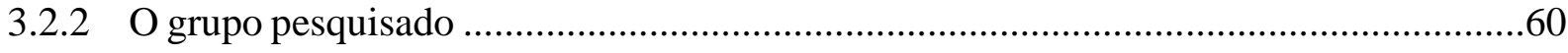

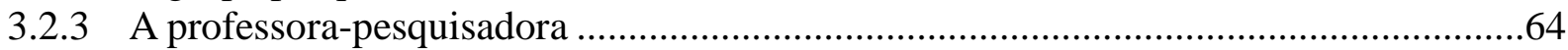

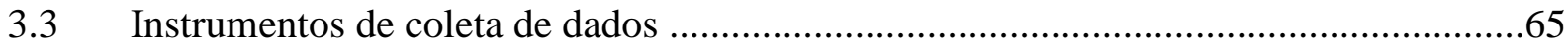

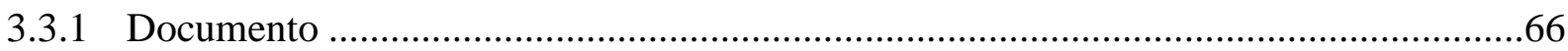

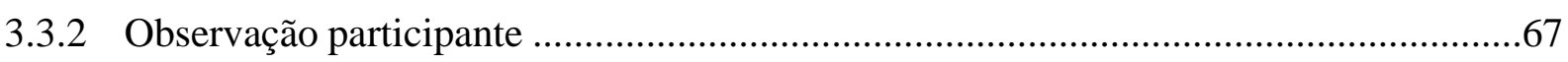

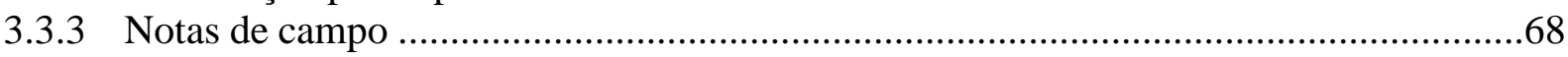

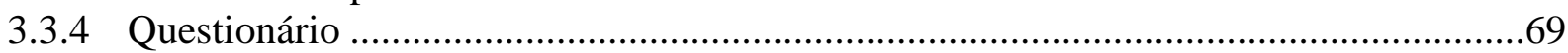

3.4 Procedimentos de coleta de dados .........................................................................

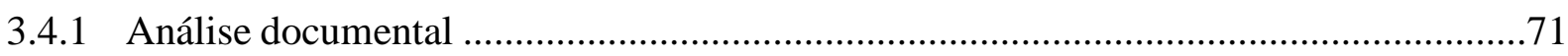

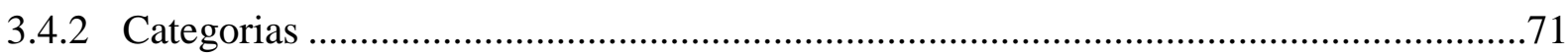

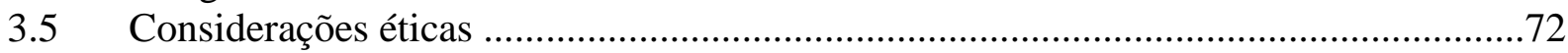


4.1 Objetivos propostos para o ensino de português como língua de acolhimento para a turma do Acolher 1 .

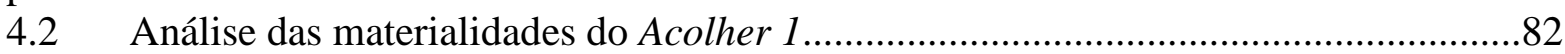

4.2.1 Descrição do material didático do Módulo Acolhimento ............................................82

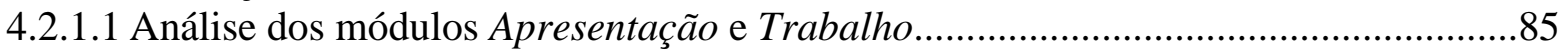

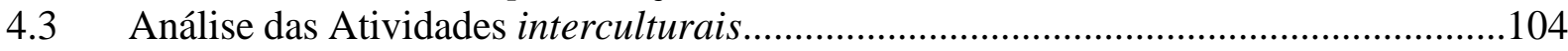

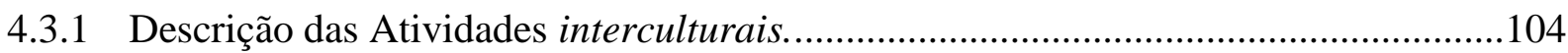

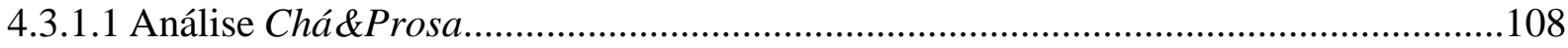

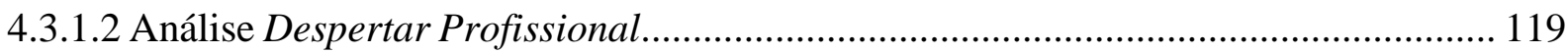

\section{CAPÍTULO V: CONSIDERAÇÕES FINAIS ...................................................... 130}

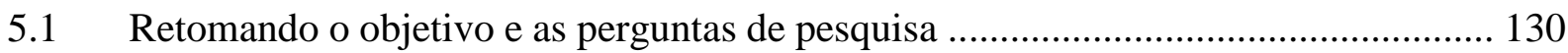

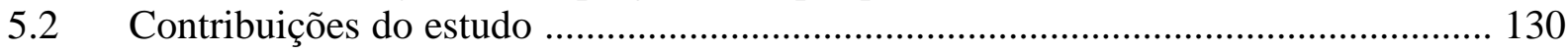

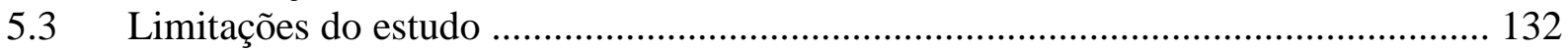

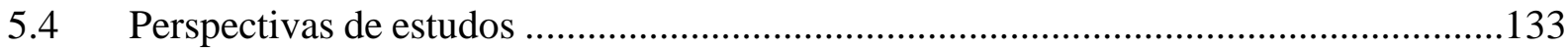

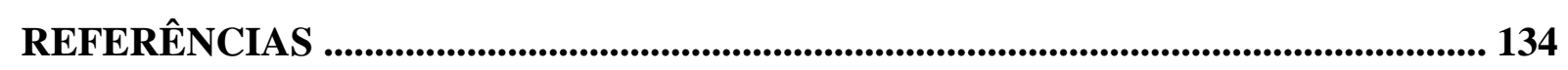

APÊNDICE A - Módulo Apresentação ……................................................................. 143

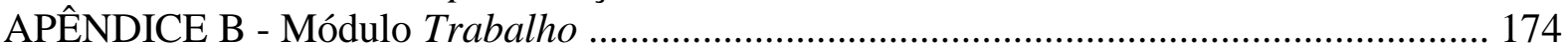

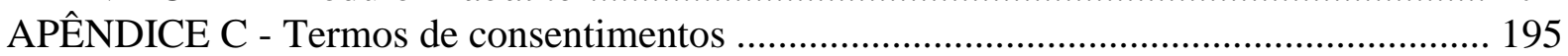

APÊNDICE D - Questionário- Perfil da turma do Acolher 1 .............................................. 197

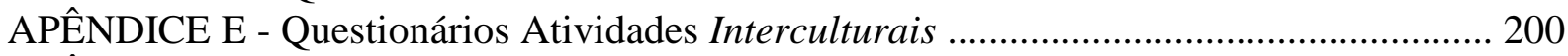

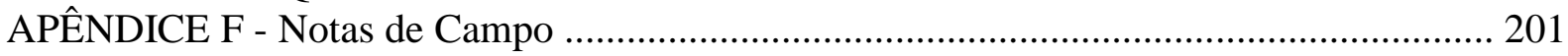




\section{CAPÍTULO I: APRESENTAÇÃO DO ESTUDO}

\section{Introdução}

A pesquisa relatada nesta dissertação está inserida na área da Linguística Aplicada, configurando-se como uma pesquisa qualitativa, sob a modalidade de estudo de caso. Esse estudo teve por finalidade definir objetivos do ensino-aprendizagem de português como língua de acolhimento (PLAc) e, de acordo com tais objetivos, reelaborar materialidades de ensino, especificamente o material didático e os procedimentos para experienciar o português.

A pesquisa foi desenvolvida em uma turma de nível iniciante (nomeada Acolher 1 ) do curso Módulo Acolhimento - Português para Refugiados e Imigrantes ${ }^{l}$. Esse curso Módulo Acolhimento $^{2}$ é ofertado pelo Núcleo de Ensino e Pesquisa em Português para Estrangeiros (NEPPE) da Universidade de Brasília (UnB), em parceria com o Instituto de Migrações e de Direitos Humanos (IMDH) e com o Alto Comissariado das Nações Unidas para Refugiados (ACNUR).

As motivações iniciais para a realização desta pesquisa surgiram após a inserção desta pesquisadora, como professora regente da turma de nível iniciante - Acolher 1, no curso Módulo Acolhimento, durante o período de dois anos. Durante essa minha experiência, pude observar e experimentar sucessos e insucessos em cada curso ofertado. Essas experiências instigaram-me a aprofundar estudos e leituras nesse âmbito de ensino-aprendizagem de língua em contexto migratório e a refletir e a rever os objetivos de ensino que propomos no Módulo Acolhimento e as materialidades de ensino que elaboramos.

A cada oferta de curso são redefinidos os objetivos de ensino e, de acordo com esses, é feita a reelaboração das materialidades de ensino. Esse processo tem sido contínuo no curso, pois a cada experiência, a cada leitura, a cada observação em sala de aula, são percebidas novas demandas e especificidades. Tendo em vista que o objetivo é oferecer um ensino que possa efetivamente atender a essas especificidades e demandas do público-aprendente, respeitando o contexto de ensino, conduzimos uma prática reflexiva e sujeita a mudanças, quando necessário.

Diante do exposto, neste estudo, com o intuito e desejo de contribuir com a área de ensino de português para refugiados e imigrantes, apresento e analiso um pouco da minha prática docente em PLAc e dos processos de ensino-aprendizagem nesse âmbito de ensino que têm sido realizado no curso Módulo Acolhimento.

\footnotetext{
${ }^{1}$ Informações mais descritivas sobre o curso serão apresentadas no capítulo metodológico.

${ }^{2}$ Ao longo do texto utilizarei apenas Módulo Acolhimento para me referir ao curso.
} 
Saliento que a escrita desta dissertação será conduzida na primeira pessoa do singular, por respeito à experiência densamente vívida desta professora-pesquisadora e por materializar a crença de que, por meio desse tipo de narrativa, eu consiga dar mais vivacidade às experiências, às vivências, às aprendizagens e aos conhecimentos adquiridos durante toda a trajetória da pesquisa aqui relatada.

Para melhor compreender o contexto em que está inserida esta pesquisa, faço uma breve discussão sobre os recentes processos imigratórios no Brasil e sobre o reflexo desses no ensinoaprendizagem de português como língua de acolhimento. Logo em seguida à contextualização, apresento a motivação para a realização da pesquisa e sua relevância, assim como os objetivos de pesquisa, as perguntas norteadoras e a organização desse trabalho.

\subsubsection{Breve panorama sobre imigração e refúgio no Brasil}

O fenômeno de imigração no território brasileiro não é um fato novo. Ele fez parte do processo de formação do povo, da cultura e da economia brasileira. No entanto, em cada época, o processo imigratório se configura de forma diferenciada e conforme afirma Paulo Sérgio de Almeida (2006), Presidente do Conselho Nacional de Imigração (CNIg), em todas as épocas as migrações apresentam desafios para os países, para as sociedades locais ou regionais e para a comunidade internacional.

Diante das conflitos humanitários que o mundo atualmente vive em decorrência de guerras, crises econômicas, tragédias naturais e outros infortúnios que afetam o cenário mundial, tem havido um crescente fluxo migratório para o Brasil. Em consequência do conflito mundial de 1939-1945, o Brasil flexibilizou a política de entrada de estrangeiros, em razão dos refugiados e deslocados do conflito, como afirmam Zamberlam et al (2014).

Desde então, o Brasil começou a ter uma postura mais aberta de acolhimento aos imigrantes e aos refugiados. Essa postura mais receptiva do Brasil pode ser notada nas políticas de acolhimento, como nas ocasiões em que o Brasil ${ }^{3}$ assinou tratados internacionais de Direitos Humanos e fez parte da Convenção das Nações Unidas, de 1951, sobre o Estatuto dos Refugiados e no seu Protocolo de 1967.

O País promulgou a Lei 9.474 de 1997, adotando nesta a definição ampliada de refugiado estabelecida na Declaração de Cartagena de 1984, que considera "violação

\footnotetext{
${ }^{3}$ O Brasil foi o primeiro país do Cone Sul a ratificar a Convenção de 1951, relativa ao estatuto dos refugiados, e a promulgar, em 1997, uma Lei Nacional de Refúgio, a Lei 9474/97.
} 
generalizada de direitos humanos" como uma das causas de reconhecimento da condição de refugiado.

A Lei Federal n. 9.474/97 assegura que:

Art. $1^{\circ}$ Será reconhecido como refugiado todo indivíduo que:

I - devido a fundados temores de perseguição por motivos de raça, religião, nacionalidade, grupo social ou opiniões políticas encontre-se fora de seu país de nacionalidade e não possa ou não queira acolher-se à proteção de tal país;

II - não tendo nacionalidade e estando fora do país onde antes teve sua residência habitual, não possa ou não queira regressar a ele, em função das circunstâncias descritas no inciso anterior;

III - devido a grave e generalizada violação de direitos humanos, é obrigado a deixar seu país de nacionalidade para buscar refúgio em outro país. ${ }^{4}$

Segundo os dados divulgados ${ }^{5}$ pelo Comitê Nacional para os Refugiados (CONARE), do balanço realizado até Abril de 2016, o Brasil possui 28.670 solicitações de refúgio, sendo a maioria dos solicitantes oriundos da África, da Ásia (inclusive Oriente Médio) e do Caribe.

Até a divulgação desses dados, o Brasil concedeu refúgio a 8.863 pessoas, de 79 nacionalidades distintas (71,8\% deles são homens). De acordo com os dados, os principais grupos são compostos por nacionais da Síria (2.298), Angola (1.420), Colômbia (1.100), República Democrática do Congo (968) e Palestina (376).

A nacionalidade haitiana, segundo os dados do CONARE, aparece como a que mais solicita refúgio, no entanto, os nacionais do Haiti desde janeiro de 2012 têm recebido a concessão do visto humanitário, devido ao agravamento das condições de vida da população haitiana em consequência do terremoto sucedido em 12 de janeiro de 2010. Esse visto pode ser solicitado na Embaixada do Brasil em Porto Príncipe, a capital haitiana. Essa categoria especial de proteção foi criada pelo Itamaraty e pelo Ministério da Justiça.

Esse visto humanitário concedido aos nacionais do Haiti, de acordo com Almeida (2016), em entrevista concedida ao Portal Brasil, é "uma medida humanitária que evita a violação de direitos na travessia irregular pela fronteira terrestre e, ao mesmo tempo, ordena esse tipo de migração" ${ }^{6}$. No entanto, Charleaux (2010) argumenta que esse visto humanitário

\footnotetext{
BRASIL. Lei n. 9.474, de 22 de julho de 1997. Disponível em: < http://www.planalto.gov.br/ccivil_03/Leis/L9474.htm>. Acesso em: 10 jan. 2017.

${ }^{5}$ Os dados divulgados no site do CONARE estão disponíveis em

<http://www.acnur.org/portugues/recursos/estatisticas/dados-sobre-refugio-no-brasil/>. Acesso em: 14 de jan.2017.

6 Disponível em: <http://www.brasil.gov.br/cidadania-e-justica/2016/09/governo-prorroga-visto-humanitariopara-haitianos>. Acesso em: 14 jan. 2017.
} 
"é um instrumento polêmico, pois embora facilite a entrada de pessoas em condição vulnerável, nega a elas a condição de refugiados a qual alguns dos solicitantes poderiam ter direito" ". As opiniões são diversas, a depender do viés de análise. Esse visto humanitário está em vigor até outubro de 2017.

Dessa maneira, os nacionais do Haiti não recebem o direito e nem o status de refugiados, mas de imigrantes. E isso tem repercussões em vários sentidos, pois há diferenças tanto em direitos quanto em sentido na caracterização de um migrante e de um refugiado.

Os nacionais sírios também recebem, desde 2013, o visto humanitário, em decorrência de a Síria estar em guerra há cinco anos. O visto pode ser solicitado nas embaixadas brasileiras localizadas nos países vizinhos à Síria. No entanto, segundo as informações do Jornal NEXO, quando os sírios chegam ao Brasil, eles trocam esse visto humanitário pelo status de refugiados.

Faço questão de retomar e discorrer sobre a diferença que há na caracterização de um migrante e de um refugiado. De acordo as informações publicadas no site do Instituto Migrações e Direitos Humanos - IMDH, o migrante é aquele que saí do seu país de origem em busca de melhorias na vida profissional, educacional, ou por outras razões pessoais, no entanto, está sob proteção de seu país de origem e pode voltar a esse quando quiser ${ }^{8}$.

Um refugiado é aquele que precisou sair ou mesmo fugir do seu país de origem em consequência de conflitos armados ou de perseguições. Essa pessoa estará protegida pelo direito internacional (Alto Comissariado das Nações Unidas para Refugiados - ACNUR e outras organizações) e, uma vez reconhecido como refugiado, não pode voltar ao seu país de origem.

A diferença em termos e sentidos reflete diretamente nos direitos e nos status do migrante, no entanto, o acolhimento para ambos deve proceder de maneira semelhante, pois segundo Barbosa e Ruano (2016, p. 362), “dificilmente alguém deixa seu país de origem, seus familiares, se não houver, um motivo muito forte para tal, que muitas vezes passa pela própria sobrevivência".

Conforme as pesquisas realizadas pelo Observatório das Migrações Internacionais OBMIGRA, pelo IMDH e pelas observações que tenho realizado em sala de aula com aprendentes ${ }^{9}$ imigrantes e refugiados, a maioria dessas pessoas encontra-se em condições de

\footnotetext{
${ }^{7}$ JORNAL NEXO. Disponível em: < https://www.nexojornal.com.br/expresso/2016/05/10/Os-refugiados-que-oBrasil-acolhe-um-balan\%C3\%A7o-de-2010-a-2015>. Acesso em: 10 jan. 2017.

8 INSTITUTO MIGRAÇÕES E DIREITOS HUMANOS (IMDH). Disponível em: <http://www.migrante.org.br/migrante/>. Acesso em: 10 jan. 2017.

${ }^{9} \mathrm{O}$ termo "aprendente" utilizado nesta dissertação, segundo Almeida Filho $(2014$, p.20) refere-se "aquele que está posto no processo de aprender uma nova língua". Optei pelo uso desse termo, ao invés de aluno, pois ele traz o sentido desse individuo estar em um contínuo processo de aprendizagem da língua e fazer parte desse processo como protagonista. No entanto, também utilizarei estudante para evitar tantas repetições.
} 
vulnerabilidade. Essa vulnerabilidade está relacionada à fragilidade social, econômica, psicológica e física que as afeta. No entanto, essa condição pode ser modificada a medida que esses imigrantes e refugiados conseguem se integrar a sociedade que os acolhe.

Saliento que o sentindo de integrar mencionado aqui não é sinônimo de assimilação. Refiro-me a integrar, no sentido proposto, em notas de rodapé, por Albuquerque, Gabriel e Anunciação (2016, p.362), como um processo dialógico para construção e negociação de sentidos, ou seja, integrar refere-se a "aquele que consegue agir de maneira autônoma, reflexiva e participativa em sua comunidade".

Para possibilitar ou facilitar essa integração do imigrante e refugiado na comunidade receptora e converter essa condição de vulnerabilidade em que se encontram, Albuquerque, Gabriel e Anunciação (2016) discorrem que é preciso e fundamental oferecer a esses indivíduos acesso a recursos materiais (bens de consumo) e a recursos simbólicos (língua, educação e amizade), pois "quanto maior o acesso a recursos materiais e simbólicos, maior o acesso a poder e a privilégios" (ALBUQUERQUE, GABRIEL e ANUNCIAÇÃO, 2016, p. 363).

Tendo isso em vista, é necessário que o Brasil e a sociedade brasileira, além da postura aberta a acordos, tratados e leis, desenvolva mais políticas de acolhimento interno para possibilitar e assegurar a esses indivíduos o acesso a bens materiais e simbólicos, de maneira que os auxilie a (re)construir suas vidas na sociedade brasileira e para que eles, efetivamente, se sintam acolhidos, na prática.

\subsection{Justificativa e relevância da pesquisa}

Considerando essa necessidade de oferecer aos imigrantes e refugiados acesso a bens materiais e simbólicos para contribuir e auxiliar no processo de integração à sociedade brasileira, essa pesquisa se torna relevante, uma vez que se propôs a investigar como promover o acesso ao bem simbólico da língua, por meio do processo de ensino-aprendizagem de português como língua de acolhimento.

Para Ançã (2003, p. 2-3) a aquisição da língua do país para o qual migrou é uma das vias poderosas para promover "a integração social, para a igualdade de oportunidades e para o exercício da plena cidadania". Sabemos que isso não se constitui uma garantia, mas uma possibilidade para que esses recém-chegados consigam, por meio da aquisição da língua do país, se comunicarem, se expressarem, compreenderem as práticas socioculturais, agirem e se movimentarem socialmente na nova comunidade, criarem redes de amizade, se defenderem, transitarem entre culturas, terem acesso a melhores oportunidades de trabalho e educação, assim 
como se sentirem seguros e acolhidos, pois, quando rompida a barreira linguística, as tensões e os desconfortos provenientes do processo e do contexto migratório poderão ser de certa maneira amenizados ou mesmo compartilhados na nova sociedade de acolhimento.

Durante minha docência no âmbito de ensino-aprendizagem de português para refugiados e imigrantes, observei e ouvi muitos relatos de aprendentes que retratavam que a maior dificuldade ou mesmo o maior obstáculo que eles tinham para conseguir agir de maneira autônoma na sociedade brasileira era a barreira linguística.

Essas observações e relatos me motivaram a realizar pesquisas nesse âmbito de ensinoaprendizagem de língua em contexto migratório, a fim de investigar de que maneira pode-se planejar e oferecer um ensino do português a esses recém-chegados no Brasil, que leve em consideração as especificidades que há nesse contexto e que promova uma aprendizagem e aquisição do português de maneira significativa e eficaz, isto é, que seja capaz de auxiliar os aprendentes a se movimentarem e agirem linguística, cultural, territorial e socialmente na sociedade brasileira.

Dessa forma, acredito que esse trabalho torna-se importante, pois objetiva contribuir para promover uma acolhida mais humanitária a esses imigrantes e refugiados, por meio do ensino-aprendizagem de português (bem simbólico), e também por contribuir para a consolidação da especialidade de português como língua de acolhimento no Brasil.

\subsection{Objetivo da pesquisa}

O intuito da pesquisa relatada nesta dissertação consiste em definir objetivos do ensinoaprendizagem de português como língua de acolhimento para uma turma de nível iniciantes (Acolher 1) e, de acordo com esses objetivos, reelaborar as materialidades de ensino, especificamente o material didático e os procedimentos para experienciar o português.

\subsection{Perguntas de pesquisa e base teórica}

A fim de alcançar esse objetivo, exponho as perguntas de pesquisa que nortearam esta investigação: 
1. Quais são os objetivos do ensino-aprendizagem de português para a turma do Acolher 1 no Módulo Acolhimento?

2. Como o material didático e os procedimentos para experienciar a língua buscaram atender aos objetivos propostos?

O quadro a seguir sintetiza o percurso proposto para esse estudo:

Quadro 1- Panorama da pesquisa: objetivo, perguntas, fonte de consulta, instrumentos de coleta e procedimento de análise

\begin{tabular}{|l|l|l|l|}
\hline \multicolumn{4}{|c|}{ OBJETIVO DA PESQUISA } \\
$\begin{array}{l}\text { Definir objetivos do ensino-aprendizagem de português como língua de acolhimento e, de acordo } \\
\text { com esses, reelaborar materialidades de ensino, especificamente o material didático e os } \\
\text { procedimentos para experienciar o português. }\end{array}$ \\
\hline $\begin{array}{l}\text { PERGUNTAS DE PESQUISA } \\
\text { Fontes de } \\
\text { informação }\end{array}$ & $\begin{array}{l}\text { Instrumentos de } \\
\text { coleta de dados }\end{array}$ & $\begin{array}{c}\text { Procedimento de } \\
\text { análise }\end{array}$ \\
\hline $\begin{array}{l}\text { Quais são os objetivos do } \\
\text { ensino-aprendizagem de } \\
\text { português para a turma do } \\
\begin{array}{l}\text { Acolher 1 no Módulo } \\
\text { Acolhimento? }\end{array}\end{array}$ & $\begin{array}{l}\text { Literatura } \\
\text { especializada, } \\
\text { experiência empírica } \\
\text { professora- } \\
\text { pesquisadora) }\end{array}$ & $\begin{array}{l}\text { Literatura } \\
\text { especializada } \\
\text { observação } \\
\text { participante }\end{array}$ & Teórico \\
\hline $\begin{array}{l}\text { Como o material didático e os } \\
\text { procedimentos para experienciar } \\
\text { a língua buscaram atender aos } \\
\text { objetivos propostos para o } \\
\text { ensino-aprendizagem do } \\
\text { português? }\end{array}$ & $\begin{array}{l}\text { Material didático, } \\
\text { avaliações, } \\
\text { procedimentos em } \\
\text { sala de aula }\end{array}$ & $\begin{array}{l}\text { Questionários, textos } \\
\text { produzidos pelos } \\
\text { alunos, observação } \\
\text { participante }\end{array}$ & $\begin{array}{l}\text { Categorização, } \\
\text { Tabulação de dados } \\
\text { e análise } \\
\text { documental }\end{array}$ \\
\hline
\end{tabular}

Fonte: Elaborado pela autora

Para o desenvolvimento desse trabalho, contei com leituras de estudos, pesquisas, teorias, teses de doutorado, dissertações de mestrado e também com informações obtidas em sites oficiais do governo brasileiro, entrevistas e publicações relacionadas com o contexto de imigração e refúgio.

Além dessas leituras, faço questão de ressaltar a importância das conversas informais que tive durante o desenvolvimento da pesquisa com professore(a)s e pesquisadore(a)s no âmbito do ensino do português como língua estrangeira. 
As informações e publicações disponibilizadas por sites oficiais: do ACNUR, IMDH, CONARE, OBMIGRA e também sites de notícias e artigos tais como Portal Brasil e Nexo Jornal contribuíram para a contextualização do panorama de imigração e refúgio no Brasil.

Para construção da fundamentação teórica, analisei textos sobre: o Ensino do Português como Língua Estrangeira (José Carlos Paes de Almeida Filho, 1992, 2013; Rosane de Sá Amado, 2013; Vilson J. Leffa, 1988, Jasone Cenoz 2008), o Conceito de ensino de Língua de Acolhimento e as especificidades desse ensino-aprendizagem (Maria Helena Ançã, 2003, 2004; Maria José Grosso, 2010; Ana Maria Oliveira, 2010; Marta Alexandra Calado Santos da Silva Cabete, 2010; Hervé Adami, 2009; Mirelle Amaral de São Bernardo, 2013, 2014, 2016; Lúcia Maria de Assunção Barbosa, 2013, 2014, 2016;), a Elaboração de materialidades de ensino (José Carlos Paes de Almeida Filho, 1994, 1996, 1997, 2011, 2012, 2013; Vilson J. Leffa, 2003; Márcio Luiz Corrêa Vilaça, 2009, 2009; Elizabeth Maria Fontão do Patrocínio, 1997; Matilde V. R. Scaramucci, 1993, 1997, 2006, Nelson Viana, 1997), as Práticas de letramentos (Guilherme Rios, 2016; Brian Vincent Street, 2012; Izabel Magalhães, 2015), a Interculturalidade no ensino de línguas (Rosângela Zanatta, 2009; Edleise Mendes, 2010; Claire Kramsch, 2009), a Formação docente de Português como Língua Estrangeira (José Carlos Paes de Almeida Filho, 2012; Vilson J. Leffa, 2001; Maurice Tardif, 2003; Paulo Freire, 2008).

Deram à luz para a condução da metodologia de pesquisa, os estudos e teorias de Chizzotti (2006), Laville \& Dionne, J (1999), Denzin \& Lincoln (2006), Freebody (2003), Stake (1994), André (1995/2001), Marconi e Lakatos (2003), Yin (2001), Moura filho (2005) e Merriam (1998), dentre outros citados para a descrição dos instrumentos de coleta de dados e análises desses.

\subsection{Organização da dissertação}

Esta dissertação, com o intuito de investigar e discorrer sobre os objetivos propostos, assim como responder às perguntas de pesquisa, se estruturou em cinco partes: Introdução, Fundamentação teórica, Metodologia da pesquisa, Análise e discussão de dados e Considerações finais. 


\section{CAPÍTULO II: FUNDAMENTAÇÃO TEÓRICA}

Neste capítulo apresento teorias e reflexões sobre o conceito de língua de acolhimento e as especificidades evidenciadas nesse processo de ensino-aprendizagem. Esse embasamento teórico deu luz à presente pesquisa, possibilitando compreender, identificar, contrapor, explicar e refletir sobre o trabalho que desenvolvi, na condição de professora e pesquisadora, no âmbito das práticas de ensino-aprendizagem de português como língua de acolhimento no curso Módulo Acolhimento: português para refugiados e imigrantes.

\subsection{O ensino-aprendizagem de português como língua estrangeira (PLE) e suas especialidades}

O português como língua estrangeira no Brasil não é algo novo, pois desde a colonização, por volta de 1500 , o português foi imposto pelos colonizadores aos nativos do Brasil, dessa forma, o português era uma língua do estrangeiro que se tornou, com a vinda da família portuguesa, a língua oficial do país.

Embora o idioma tenha chegado na forma de língua estrangeira, a área conhecida como Português Língua Estrangeira (PLE), na modalidade brasileira, ainda é recente, no entanto, de acordo com Costa; D’Andrea e Santana (2009) essa área vem recebendo cada vez mais espaço e atenção especial de professores e pesquisadores,

No Brasil, segundo Amado (2013), o ensino de português como língua estrangeira (PLE) tem se apresentado da seguinte maneira:

\footnotetext{
um crescente movimento nas últimas décadas, com a criação de cursos de PLE em escolas de idiomas e de cursos de extensão à comunidade acadêmica nas universidades. Os primeiros, contudo, voltam-se, majoritariamente, a um público de trabalhadores de grandes empresas e suas famílias; já os últimos prestam um serviço para alunos intercambistas e professores visitantes que, via de regra, permanecem de um a dois anos no Brasil. Há também os cursos voltados aos turistas que chegam ao país para os eventos do cenário esportivo, a Copa de 2014 e as Olimpíadas de 2016. São, portanto, públicos com necessidades específicas de aprendizado nos contextos em que se comunicarão em português. (AMADO, 2013, p.05).
}

Como apresentado pela por Amado, as ofertas de cursos de português para estrangeiros no Brasil têm aumentado, fato que vem influenciando e colaborando para que a área de PLE receba mais atenção, contudo, a formação docente de PLE ainda é algo recente nas Universidades brasileiras. 
Como frisado por Amado (2013), o interesse pelo português parte, muitas vezes, de necessidades específicas de aprendizado, dessa forma, temos dentro desse grande sistema de português como língua estrangeira (PLE) diversas especialidades de ensino e aprendizagem, tais como o português como segunda língua (L2/LS), português como língua de herança (PLH), português como língua adicional (PLA) e, a mais recentemente, o português como língua de acolhimento (PLAc), dentre outras que existem e vão surgindo.

Ter o conhecimento dessas especialidades, sobretudo quando se trata do profissional de línguas, é importante, pois cada ensino-aprendizagem engendra dinâmicas e processos de ensino diferentes e específicos que refletem, de acordo com Almeida Filho (2013), na abordagem, no planejamento de curso/aula, no material didático e na avaliação de proficiência da língua-alvo.

Pela ótica de teorias e pesquisas desenvolvidas dentro da Linguística Aplicada (LA), todas as especialidades mencionadas estão dentro da área de português como língua estrangeira e têm em comum a aquisição ou aprendizagem de uma outra língua, que não seja a língua materna.

No entanto, elas se diferenciam na concepção e no contexto que cada processo de ensino-aprendizagem apresenta. Vale ressaltar que há uma vasta discussão acerca das nomenclaturas mencionadas com compreensões que ora se assemelham ora se distanciam, não entrando em um consenso geral. Tendo isso em vista, discorrerei brevemente sobre as definições que, no meu ponto de vista, melhor serviram-me para elucidar o conceito de cada especialidade.

Para a compreensão dos aspectos que distinguem segunda língua de língua estrangeira, tomo o conceito e exemplo dado por Leffa (1988), que, de maneira didática, nos explica:

\footnotetext{
temos o estudo de uma segunda língua no caso em que a língua estudada é usada fora da sala de aula em que vive o aluno (exemplo: situação do aluno brasileiro que foi estudar francês na França). Temos língua estrangeira quando a comunidade não usa a língua estudada na sala de aula (exemplo: situação do aluno que estuda inglês no Brasil). (LEFFA, 1988, p. 212).
}

De acordo com Leffa, segunda língua é a língua não materna aprendida ou adquirida em um processo de imersão, isto é, onde a língua é usada pela comunidade, como língua estrangeira é a língua não materna aprendida em um ensino formal ou não, não sendo essa língua usada pela comunidade.

Além da compreensão oferecida por Leffa, há outras perspectivas sobre segunda língua, como, por exemplo, a de Souto, Além, Brito e São Bernardo (2014) que dissertam que a segunda 
língua também pode ser aquela que é tida como língua oficial do país, mas que não é muito utilizada pela sociedade mais formal, como exemplo, citam o caso do guarani no Paraguai, que é preterido em relação à língua espanhola e ainda, conforme relatam as pesquisadoras, "o guarani por ser oficial é ensinado na escola somente até o terceiro ano do fundamental I, o que a criança aprende depois é no meio em que está inserida, ou seja, família e sociedade. Assim essa língua passa a ser a segunda" (SOUTO, ALÉM, BRITO E SÃO BERNARDO, 2014, p.893).

O português como língua de herança, segundo Almeida Filho (2010) 10 "se caracteriza como um contexto em que o Português e a cultura (brasileira, no nosso caso) são ensinados a filhos de brasileiros imigrados no exterior”. A língua de herança, conforme Almeida Filho \& Schmitz (1998) definem no Glossário de Linguística Aplicada (GLOSSA) ${ }^{11}$, é ensinada com o intuito de fortalecer e preservar o patrimônio cultural.

O português como língua adicional também chamada por alguns teóricos e pesquisadores de L3 se relaciona ao ensino-aprendizagem de uma terceira língua não-nativa. Segundo Cenoz (2008), esse ensino-aprendizagem acontece em contextos bilíngues e multilíngues, nos quais, devido a razões históricas ou políticas, são utilizadas duas ou mais línguas, destacando que "também é comum no caso de indivíduos que precisam se comunicar em várias línguas e em escolas onde são ensinadas duas ou mais línguas estrangeiras” (CENOZ, 2008, p.219, tradução minha). ${ }^{12}$

E, por fim, o português como língua de acolhimento, especialidade que norteia a pesquisa aqui relatada, cujo sentido concerne ao ensino-aprendizagem de português como língua de acolhida em contextos migratórios como, por exemplo, para refugiado(a)s e para população de imigrantes que se encontram em condição de vulnerabilidade.

Cabete (2010) citando Baetriz Soto Aranda e Mohamed El- Madkouri (2006), diz que o conceito de língua de acolhimento "relaciona-se com a sociedade que recebe o indivíduo e que se refere a um tipo de segunda língua (L2) adquirida num contexto migratório" (2010, p.67). Trata-se do ensino-aprendizagem de uma segunda língua ou de uma terceira língua em contexto de imersão que, no entanto, se diferencia, de acordo com Oliveira (2010), de qualquer outro ensino tradicional de uma segunda língua, tanto pelo contexto migratório quanto pela necessidade do(a)s aprendentes. Essas diferenças aqui tratadas como especificidades serão

\footnotetext{
${ }^{10}$ ALMEIDA FILHO, José Carlos P. Entrevista. Disponível em < http://www.sala.org.br> Acesso em: 20. dez.2016.

${ }^{11}$ Disponível em: <http://glossario.sala.org.br>. Acesso em: 14 jan. 2017.

12 Trecho original: "it is also common in the case of individuals who need to communicate in several languages and in schools where two or more foreign languages are taught" (CENOZ, 2008, p.219).
} 
melhor discutidas na seção 2.2.1. Passo a seguir à discussão sobre o conceito de língua de acolhimento.

\subsection{Português como língua de acolhimento}

O termo língua de acolhimento, conforme apresenta Cabete (2010), desenvolveu-se em Portugal a partir de 2001 com os cursos de português direcionados exclusivamente a imigrantes adultos. Esses cursos estavam inseridos no programa Portugal Acolhe, criado pelo Estado português.

Tanto Portugal quanto o Brasil foram e são constituídos por processos migratórios que mudaram e mudam conforme os tempos e as circunstâncias mundiais, no entanto, Portugal em teorias e estudos sobre a língua de acolhimento, tem tomado frente e sido referência para nós pesquisadore(a)s brasileiro(a)s.

Acredito que isso acontece tanto por possuirmos em comum a língua portuguesa quanto por apresentarmos processos migratórios semelhantes, tal qual o recebimento de migrantes em condição de vulnerabilidade e refugiado(a)s.

Gostaria de ressaltar que não estou desconsiderando a existência de outros estudos sobre o tema, tais como os estudos franceses de Adami (2009) relacionados à formação linguística dos imigrantes, no entanto, para este trabalho no âmbito de definições dos conceitos e desenvolvimento da língua, como língua de acolhimento, as portuguesas Grosso, Oliveira e Cabete nos auxiliaram diante da necessidade de compreender, e, até mesmo redimensionar o conceito de língua de acolhimento, trabalho esse realizado pelas brasileiras Barbosa e São Bernardo.

Essa ampliação na compreensão do conceito de língua de acolhimento, proposto pelas autoras supracitadas, será apresentado ao longo desta seção e tomado como norte para o desenvolvimento desse trabalho, além disso, temos também a pesquisadora brasileira Amado, que traz reflexões, relatos e pesquisas pertinentes ao contexto desse conceito e de trabalhos desenvolvidos, no Brasil, nesse âmbito de ensino-aprendizagem.

Como mencionado brevemente na seção 2.2, a língua de acolhimento está ligada ao contexto migratório. Grosso (2010), sintetizando o conceito de língua de acolhimento explica:

o conceito de língua de acolhimento aproxima-se da definição dos conceitos de língua estrangeira e língua segunda, embora se distinga de ambos. É um conceito que geralmente está ligado ao contexto de acolhimento, expressão que se associa ao contexto migratório, mas que, sendo geralmente um público adulto, aprende o 
português não como língua veicular de outras disciplinas, mas por diferentes necessidades contextuais, ligadas muitas vezes à resolução de questões de sobrevivência urgentes, em que a língua de acolhimento tem de ser o elo de interação afetivo (bidirecional) como primeira forma de integração (na imersão linguística) para uma plena cidadania democrática. (GROSSO, 2010, p 74).

Quando Grosso pontua que a língua de acolhimento se aproxima e ao mesmo tempo, ultrapassa o conceito de língua estrangeira e língua segunda, compreendo que essa aproximação se dá, respectivamente, pelo fato de ser um ensino-aprendizagem de uma língua não-nativa e pela aprendizagem e aquisição dessa língua se desenvolver em um processo de imersão, ou seja, no país de acolhida. No entanto, ultrapassa esses conceitos, pois a língua de acolhimento apresenta especificidades que estão ligadas ao contexto migratório, ao público e às necessidades e motivações de aprendizagem e aquisição da língua.

Embasada nas leituras que tenho realizado e pela própria experiência de trabalho nesse âmbito de ensino, discorro brevemente sobre alguns fatores e atravessamentos envoltos nesse ensino.

Relacionados ao contexto, de acordo com Barbosa e São Bernardo (2013), destaco a tensão do movimento migratório, a condição de vulnerabilidade (social, psicológica e econômica) em que esses indivíduos se encontram ao chegarem a um país novo, no qual, muitas vezes, não gostariam de estar (menciono o refugiado (a) que, por fatores externos, é obrigado(a) a deixar o seu país e procurar um refúgio em outro país), o choque cultural que muitos migrantes enfrentam, por apresentarem culturas e costumes distintos do país de acolhida e as inúmeras dificuldades, em consequência da barreira linguística, de se comunicarem, de compreenderem as práticas socioculturais, de agirem e de se movimentarem socialmente na nova comunidade.

No que concerne ao público-aprendente, conforme observei durante o trabalho realizado no curso Módulo Acolhimento, constitui-se de um público diverso, heterogêneo, multilíngue, multicultural, multifacetado, com diferentes perfis e níveis de escolaridade, assim como maneiras distintas de aprender e com bagagens de vivências culturais diversas. ${ }^{13}$

E referente às necessidades e às motivações de aprendizagem e de aquisição da língua, recorro ao que Grosso (2010) nos aponta sobre essas estarem ligadas a questões de sobrevivência, de necessidade urgente de conseguirem se movimentar socialmente no novo país e, assim, suprirem as necessidades básicas, como conseguir um emprego, alugar uma casa, ir ao médico, entre outras ações imprescindíveis à sobrevivência.

\footnotetext{
${ }^{13}$ Ressalto que essas percepções foram feitas durante as aulas e também por meio de um questionário que normalmente aplicamos no primeiro ou segundo dia de aula. Esse questionário tem por objetivo conhecer um pouco sobre o perfil do público-aprendente. O modelo desse questionário por ser consultado do Apêndice D Questionário - Perfil da turma do Acolher 1, p. 197.
} 
Além disso, nesse contexto de ensino, não se pode deixar de considerar a necessidade e o desejo de ser acolhido(a) e a motivação ou mesmo a precisão de fazer parte da nova sociedade e de se integrar socialmente no país de acolhimento.

Tendo em vista os fatores e atravessamentos que envolvem esse ensino-aprendizagem, devemos refletir, de acordo com Barbosa (2016), em palestra proferida nos Diálogos do Observatório "Migrações e Deslocamentos na América Latina"14, sobre o que o ensinoaprendizagem da língua de acolhimento QUER e o que ele PODE?

Partindo do próprio termo "acolhimento" compreendo, primeiramente, que o ensinoaprendizagem dessa língua QUER “acolher, alojar, asilar, acomodar e recolher” (BARBOSA e SÃO BERNARDO, 2017, no prelo), isto é, ser "refúgio em casa, forte, cidade, praça" (ANÇA, 2004), além disso, acredito que esse ensino quer inserir, incluir esses indivíduos na nova sociedade.

Para Ançã (2003, p. 2-3), conforme mencionado na seção 1.2, aquisição da língua de acolhimento (a língua do país para o qual migrou) é uma das vias poderosas para promover "a integração social, para a igualdade de oportunidades e para o exercício da plena cidadania", no entanto, sublinho que isso é o que se quer e almeja, não sendo, portanto, uma garantia, pois há outros fatores e variáveis que influenciam nesse processo e devem ser levados em conta, tais como o "prisma emocional e subjetivo da língua e à relação conflituosa presente no contato inicial do imigrante com a sociedade de acolhimento", como trazem Barbosa e São Bernando (2017, no prelo).

Esse aspecto relativo ao prisma emocional e à relação conflituosa, colocados por Barbosa e São Bernardo (2017, no prelo) ampliou o conceito ${ }^{15}$ de língua de acolhimento, de maneira que o redimensiona. De acordo com a perspectiva dessas autoras, o prisma emocional e a relação conflituosa estão relacionados, muitas vezes, com a situação de vulnerabilidade social, econômica e psicológica em que se encontram os migrantes quando chegam a um país estrangeiro.

É importante frisar que essa vulnerabilidade e tensão de emoções devem ser levadas em conta ao se planejar e conduzir o ensino-aprendizagem da língua como acolhimento, pois isso interfere, de acordo com Barbosa e São Bernando (2017, no prelo), em toda a dinâmica em que

\footnotetext{
${ }^{14}$ Essa palestra fez parte das atividades do Curso de Extensão Migrações Internacionais na América Latina, realizado no dia 02 de junho, às $15 \mathrm{~h}$, na Fundação Darcy Ribeiro da Universidade de Brasília. A palestra foi direcionada a discorrer sobre Ensino de português e integração do imigrante: o que quer e o que pode essa língua? ${ }^{15}$ Essa ampliação do conceito se concretizou por meio de verbete "língua de acolhimento" - elaborado por BARBOSA, Lucia Maria de Assunção e SÃO BERNARDO, Mirelle Amaral - que será publicado no Dicionário das Migrações Internacionais", pela Editora UnB (Editora da Universidade de Brasília), em 2017, como parte das publicações do Observatório das Imigrações Internacionais (ObMigra).
} 
se desenvolve esse ensino, tais como no papel e na formação do(a) professor(a) que atua nesse contexto, no planejamento das aulas, no material didático e, acrescento também, no processo avaliativo. Essa dinâmica de ensino-aprendizagem será melhor abordada nas seções seguintes.

Retomando a questão do que o ensino-aprendizagem da língua de acolhimento QUER, Barbosa (2016) salienta que esse ensino quer e deve aumentar a autoestima do grupo, valorizar as culturas que chegam ao país de acolhida, interessar-se por essas culturas, dar visibilidades às culturas e também reconhecer os seus limites, isto é, muitas vezes, o que esse ensino quer e deseja propiciar nem sempre é possível ou mesmo alcançado e isso deve ser reconhecido.

No que tange àquilo que o ensino-aprendizagem da língua de acolhimento PODE, embasada em Barbosa (2016), compreendo que esse poder é o de acolher e amenizar o conflito e as tensões do processo migratório, propiciar modos de se exprimir; estabelecer ou possibilitar a comunicação com os nativos; auxiliar no transitar entre culturas, e no compreender e interpretar as práticas socioculturais vinculadas à sociedade de acolhida, contribuindo para conceder autonomia aos aprendentes para poderem movimentar e agir socialmente como para se defenderem contra pré-conceitos, racismo e discriminações.

Considero relevante destacar esse poder da língua de acolhimento, pois ela pode ou poderá colaborar para a alteração das representações negativas que a população da sociedade de acolhida tem ou faz sobre as diferentes culturas que chegam ao país. Assim, essa língua tem o poder de nos tornar melhores, como sociedade, capazes de compreender o quanto podemos nos enriquecer com as trocas culturais que o contato com os imigrantes propicia.

Além disso, esse ensino-aprendizagem da língua, conforme tenho observado durante o meu trabalho nesse contexto de ensino, pode facilitar ou promover a integração desse imigrante na sociedade envolvente, a criação de redes de amizades, pode possibilitar um crescimento profissional (acesso a melhores oportunidades de trabalho e educação), ou ter uma segurança e conforto, já que, com o domínio da língua do país, as tensões e desconfortos poderão ser amenizados.

O ensino-aprendizagem dessa língua pode também colaborar para que o(a)s migrantes construam processos de ressignificação ou mesmo re-existência, uma vez que aprender/adquirir uma língua forja identidades, ou seja, em consonância com o que afirma Rajagopalan (2003, p.41) “a identidade de um indivíduo se constrói na língua e através dela”. E nesse contexto, a ressignificação e re-existência se tornam processos importantes e necessários para alguns aprendentes.

Assim, considerando o contexto de ensino, o público, as necessidades e as motivações dos aprendentes, bem como o que quer e o que pode o ensino-aprendizagem da língua de 
acolhimento, disserto sobre algumas especificidades que devem e/ou podem ser consideradas ao conduzir esse ensino.

Saliento que as especificidades que apresento, na seção a seguir, estão relacionadas ao ensino-aprendizagem da língua como acolhimento, foram identificadas por meio das leituras que realizei de estudos, teorias e pesquisas voltadas a esse âmbito de ensino de língua em contexto migratório e também através da experiência que tive durante o tempo de trabalho como professora do nível Acolher 1, no curso Módulo Acolhimento: curso de português para refugiados e imigrantes. Portanto, as especificidades estão localizadas no contexto de trabalho mencionado, podendo divergir de outros contextos.

\subsubsection{Especificidades do ensino-aprendizagem de português para refugiados e migrantes}

Considerando-se o conceito, as discussões apresentadas acerca da língua de acolhimento, assim como o contexto, o público-aprendente e os focos de interesses e motivações que envolvem esse ensino-aprendizagem, apresento, nesta seção, algumas especificidades que devem ser consideradas para conduzir essa modalidade de ensino.

De acordo com Cabete (2010), tem sido alvo de reflexão por vários autores o fato de o processo de ensino-aprendizagem de uma língua por migrantes ser ou não diferente do processo de ensino-aprendizagem por outros grupos de aprendentes. Pela perspectiva de Oliveira (2010), esse ensino se diferencia profundamente de qualquer outro ensino tradicional de uma segunda língua, pois ele apresenta fatores que são específicos do contexto de migração e integração que refletem diretamente no ensino e na aquisição da língua.

Oliveira (2010, p.11) ainda aponta que neste contexto "os fatores sociopsicológicos desempenham um papel tanto ou mais importantes do que o desenvolvimento psicolinguístico". Ela discorre que as situações sociais e psicológicas que a maior parte dos migrantes adultos enfrentam na nova sociedade devem ser levadas em conta nesse processo de ensinoaprendizagem. Algumas dessas situações citadas pela autora são: a perda do estatuto social e as redes sociais que tinham e o ambiente familiar, assim como a experiência de declínio social, o problema econômico que muitos migrantes passam, o constrangimento social, a discriminação e, por vezes, os preconceitos e racismos que esses indivíduos enfrentam na nova sociedade.

Diante desses fatores sociais e psicológicos que envolvem esse contexto de ensinoaprendizagem, Oliveira conclui (2010) que: 
os programas de aquisição da segunda língua para adultos migrantes, na linha do que temos defendido, devem ter em conta as necessidades da língua de origem e a situação mental e psicossocial do migrante. É obvio que o ensino de uma segunda língua em contexto migrante difere profundamente de qualquer outro ensino tradicional de uma segunda língua. (OLIVEIRA, 2010, p.12).

A autora, ao afirmar que os ensinos se diferem, cita três especificidades do ensino e dos níveis a atingir que devem ser consideradas no contexto de migração. As especificidades são:

- a aquisição da segunda língua do migrante tem lugar em contextos tão variados como a sala de aula ou o meio que o envolve;

- a aprendizagem da segunda língua tem lugar num ambiente de maior pressão social, legal, económica, etc, do que num contexto normal de aprendizagem. Têm necessidades linguísticas precisas, dependendo das necessidades e exigências práticas da sociedade em que estão integrados. Por este motivo, há que ter em conta, no ensino da língua segunda, as situações comunicativas específicas nos vários contextos psicossociais e psicolinguísticos;

- a natureza multilíngue em situação de sala de aula. Tradicionalmente, falávamos de grupos homogéneos; com grupos de migrantes, a base linguística (uma ou mais línguas, nem sempre adquiridas correctamente, com eventual iliteracia), o contexto linguístico (o uso de diferentes línguas em casa e fora da sala de aula) e a motivação ou pressão para aprender uma língua difere do contexto de aprendizagem de uma língua estrangeira. (OLIVEIRA, 2010, p. 12).

Destaco que as especificidades apontadas por Oliveira puderam ser evidenciadas durante a experiência que tive no curso Módulo Acolhimento, na qual contribuí para redefinir e ampliar os objetivos de ensino e reelaborar as materialidades: o planejamento, o material didático, os métodos e procedimentos e avaliações.

A primeira especificidade referente aos variados contextos em que o migrante pode adquirir a língua-alvo pôde ser observada no próprio desenvolvimento das aulas, quando os aprendentes solicitavam vocabulários, verbos, expressões, nomes de objetos que pertenciam e eram utilizados em diferentes contextos, sobretudo, em circunstâncias cotidianas, tais como em meios referentes a trabalho, a saúde, a parte administrativa, a alimentos, dentre outras situações rotineiras.

Tendo em vista essas solicitações feitas em sala de aula, nota-se que de fato os imigrantes, por necessidades variadas, seja para conseguir um emprego, para ir ao médico, para fazer compras, seja para pedir ajuda ou mesmo informações, têm contato com diferentes 
contextos que possibilitam e/ou exigem uma aprendizagem e aquisição de uso real da línguaalvo $^{16}$.

À vista dessa primeira especificidade, o ensino neste cenário deve focar em atender a essa demanda de extrapolar situações de sala de aula e trabalhar com diferentes circunstâncias que os aprendentes supostamente enfrentam ou enfrentarão no dia a dia. Isto é, as dinâmicas de sala de aula, os conteúdos, os temas, os materiais, as atividades e as situações escolhidas para trabalhar o ensino-aprendizagem da língua devem ser cuidadosamente selecionados para que sejam coerentes e significativos com o uso efetivo e real da língua em aquisição.

As pesquisadoras Barbosa e São Bernardo (2014), atentas a essa primeira especificidade apontada por Oliveira (2010), instruem que esse ensino deve oferecer uma capacitação linguística necessária e diversificada para que os aprendentes possam agir em diferentes situações comunicativas. Segundo afirmam as autoras:

\footnotetext{
é essencial que um curso ofereça a capacitação linguística necessária à comunicação e aos afazeres do dia-a-dia; portanto, o desenvolvimento da competência comunicativa dos alunos - e, consequentemente, das subcompetências que a compõem, incluindo a intercultural - é de extrema importância. (BARBOSA e SÃO BERNARDO, 2014, p. 271).
}

Efetivamente, como pude observar durante as aulas no curso Módulo Acolhimento, a importância de oferecer um ensino que se norteia para o desenvolvimento da competência comunicativa e intercultural advém da necessidade de acolher as prementes demandas dos aprendentes que precisam se movimentar na nova sociedade de forma que consigam compreender e serem compreendidos, tanto no âmbito da comunicação verbal quanto no que se refere às práticas socioculturais que estão diretamente ligadas à cultura da sociedade envolvente.

Dessa maneira, segundo Grosso (2010), esse ensino precisa ser orientado para estabelecer ligação entre o agir linguístico e as situações cotidianas, isto é, ele deve ser conduzido, de acordo com a autora supracitada, "para um saber fazer que contribui para uma interação real, a vida cotidiana, as condições de vida, as convenções sociais e outras que só podem ser compreendidas numa relação bidirecional” (GROSSO, 2010, p.71). Saliento que

\footnotetext{
${ }^{16}$ Quando refiro-me a “ aprendizagem e aquisição de uso real da língua-alvo” relaciono ao desenvolvimento da competência comunicativa e intercultural que um aprendente desejosamente deve buscar ao se aprender ou adquirir uma nova língua. Isto é, deve-se desenvolver a capacidade de utilizar a língua alvo no dia-a-dia, seja em casa, no trabalho, na rua, dentre outras situações recorrentes cotidianamente.
} 
essa maneira de ensino proposta por Grosso (2010) deveria orientar não somente esse contexto de ensino, mas todos os demais referentes ao ensino de língua.

No que concerne à segunda especificidade mencionada por Oliveira (2010), referente ao fato de a aprendizagem da segunda língua se desenvolver num ambiente de maior pressão social, legal e econômica, esse é o ponto crucial que diferencia enormemente esse ensinoaprendizagem de outro ensino que não é alcançado por nenhum desses fatores. Portanto, essa especificidade deve ser considerada ao planejar e conduzir o ensino neste contexto, pois ela reflete diretamente tanto no ensino-aprendizagem quanto na aquisição da língua.

De acordo com Amado (2013, p.07) "não só os fatores linguísticos devem ser considerados. As condições psicossociais do refúgio, como alertam Villalba Martinez e Hernández (2005), podem gerar barreiras para o aprendiz da língua do país de acolhida”. Essas condições psicossociais, tanto do refúgio quanto do próprio processo de migrar para outro país, seja por distintos motivos, contribuem para tornar esse ambiente ainda mais afetado por pressão social, psicológica e econômica.

Ao que se refere a pressão psicológica, quero ressaltar, que essa, muitas vezes, tem início desde a saída desse migrante do seu país de origem e ela acaba por atravessar oceanos, idade, gênero, cultura e língua. No entanto, essa pressão acaba por se acentuar ainda mais quando esses migrantes chegam ao novo país, pois nesta fase outras preocupações se apresentam e acabam por intensificar esse fator, tais como ansiedade e necessidade de se integrar na nova sociedade, de adquirir a nova língua do país, de compreender as práticas socioculturais presentes na sociedade que o acolhe e, assim, de poder se movimentar e agir socialmente.

Muitos dos indivíduos a partir do momento que migram para outro país, seja forçadamente ou pela busca de sobrevivência, já são afetados psicologicamente pelo movimento migratório. Tenho observado no Módulo Acolhimento que alguns migrantes apresentam marcas mais visíveis de momentos e fatos trágicos, tais como os refugiados de guerra, outros com menos visibilidade, no entanto, sofrem com pressões psicológicas tão graves quanto. Além dessa pressão estar ligada à própria tensão do movimento migratório, há também outras que são destacadas por Amado (2013), tais como o afastamento dos laços familiares e linguístico-culturais.

Tendo em vista os apontamentos apresentados de Oliveira (2010) e de Amado (2013) e as observações que tenho realizado durante a minha docência nesse contexto de ensino, tenho a dizer que a pressão psicológica engloba um processo profundo e complexo que precisa de muita atenção e cuidado, tanto pelo ensino da língua quanto por profissionais da área da psicologia. 
Com relação a pressão econômica apontada por Oliveira (2010), notei, no curso Módulo Acolhimento, que essa se refere à dificuldade desses indivíduos em conseguirem recursos financeiros para poder suprir as necessidades básicas no novo país.

A questão relacionada ao trabalho, conforme minhas observações, é a mais presente entre o público-aprendente, que muitas vezes, por inúmeras dificuldades, tais como ser migrante, não ter o domínio da língua do país, não ter redes de contato, não ter como comprovar experiências de trabalho (alguns chegam sem certificados ou documentos que comprovem) e, em alguns casos, por não conseguirem validar os diplomas de ensino superior no Brasil (a validação de diploma no Brasil demanda tempo e dinheiro, o que se torna inacessível para muitos migrantes), se encontram em condições financeiras desfavoráveis.

Todos esses fatores relacionados às pressões e tensões que o público-aprendente enfrenta no processo migratório têm que ser consideradas no ensino-aprendizagem da línguaalvo, pois eles engendram dinâmicas/movimentos específicos para esse ensino, visando atender às necessidades do público-aprendente, considerando os seus atravessamentos, os seus limites, as suas recusas e as dificuldades pelas quais passam.

Oliveira (2010), ao apontar a segunda especificidade, ressalta que esse públicoaprendente tem necessidades linguísticas precisas que dependem das exigências práticas da sociedade em que estão integrados e que por esse motivo é necessário que o ensino atenda às situações comunicativas específicas que ocorrem nos diversos contextos psicossociais e psicolinguísticos. Isto é, o ensino nesse contexto tem seus fins específicos que não podem ser ignorados, ao contrário, devem ser o norte para o planejamento e elaboração das aulas, dos materiais utilizados e de toda prática.

A terceira e última especificidade citada por Oliveira (2010), está relacionada ao que já comentei na seção anterior quando tratei sobre o público-aprendente, que se caracteriza por ser um público diverso, heterogêneo, multilíngue, multicultural, multifacetado, com diferentes perfis e níveis de escolaridade e com motivações, ou tensões, para aprender línguas estrangeiras distintas daquelas de um aprendente que ambiciona aprender a língua por prazer ou mesmo por tramites turísticos ou por conhecimento.

Dessa forma, tendo ciência das especificidades descritas, acredito que a prática de ensino não pode ignorá-las, antes pelo contrário, tal prática deve levá-las em consideração e se deixar guiar por elas. Diante do conceito de língua de acolhimento e das especificidades apresentadas nesta dissertação, apresento na seção seguinte uma síntese que envolve todos esses fatores. 


\subsubsection{Síntese do contexto e dos fatores do ensino-aprendizagem de língua de acolhimento}

Considerando que para traçar ou definir objetivos de ensino, segundo Viana (1997), é preciso fazer uma "radiografia" de todo o contexto que abarca esse ensino, apresento uma síntese geral do contexto e fatores presentes no ensino-aprendizagem da língua de acolhimento, de acordo com as teorias e estudos citados nesta dissertação e com a minha experiência nesse âmbito de ensino.

Figura 1- Síntese do contexto e fatores do ensino-aprendizagem da língua de acolhimento, baseada nas colocações de Oliveira (2010) e Barbosa (2016).

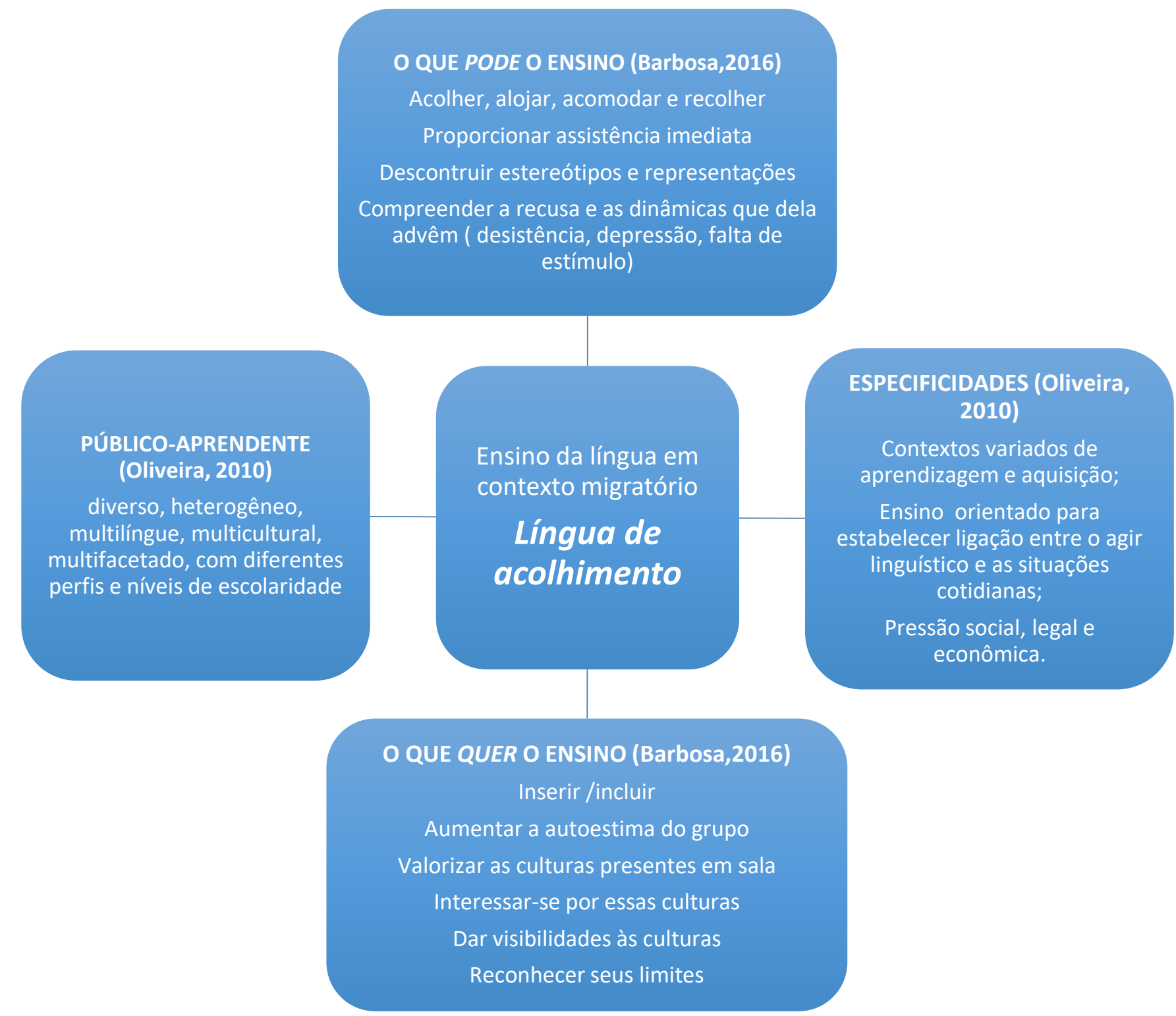

Fonte: Elaborado pela autora. 
Além de ter o conhecimento do contexto de ensino da língua de acolhimento é também fundamental investigar quais são os objetivos e as motivações que o público-aprendente tem em aprender e adquirir essa língua.

Reconheço que muitas vezes é difícil para o professor identificar quais são os objetivos dos estudantes e, mais complicado ainda, no meu ponto de vista, é conciliar os diferentes objetivos e motivações existentes em uma mesma sala de aula, pois esses podem variar a depender do fator social, do econômico, da faixa etária, do nível de escolaridade, dentre outros fatores. No entanto, essa investigação é necessária, pois colabora para construir um ensino mais interessante e eficaz para o próprio aprendente.

Atendendo a essa necessidade de ter um prévio conhecimento sobre os interesses do público-alvo e embasada pela experiência obtida no Módulo Acolhimento, e pelas teorias nesses âmbitos, faço uma discussão dos possíveis interesses que os imigrantes e refugiados têm em aprenderem e adquirirem a língua de acolhimento.

Faço uma ressalva sobre o fato de que os objetivos e as motivações podem variar a depender dos fatores citados acima, no entanto, para esse trabalho, tomo como norte os apontamentos feitos, por alguns teóricos, sobre o objetivo dos imigrantes em relação à aquisição da língua de acolhimento.

Para Adami (2009) o objetivo dos imigrantes em relação à aquisição da língua é:

o objetivo dos imigrantes, frente a situações linguareiras, aos jogos sociais e práticas muito importantes, é simples: compreender e ser compreendido. Face a esse imperativo pragmático, os outros aspectos são secundários, como o respeito às normas linguísticas notadamente. (ADAMI, 2009, p.38-39, tradução minha). ${ }^{17}$

Essa colocação de Adami corrobora as ponderações feitas por Grosso (2010) e Barbosa e São Bernardo (2013), de que aprendizagem e aquisição da língua pelo imigrante em condição migratória e de vulnerabilidade não é, muitas vezes, uma escolha, mas uma necessidade ditada pelos imperativos da vida cotidiana, pois a sua aquisição poderá possibilitar e facilitar uma integração à nova sociedade.

Tendo em vista esse objetivo, entendo que a motivação/necessidade/interesse desses imigrantes em adquirirem a língua do país para o qual migraram não se restringe, dessa forma, apenas à aprendizagem da língua e de suas regras, mas, de fato, pretende a sua aquisição, pois

\footnotetext{
17 Trecho original: "l'objectif des migrants, confrontés à des situations sociolangagières complexes, aux enjeux sociaux et pratiques três importants, est simples: comprendre et se faire comprendre. Face à cet impératif pragmatique, les autres aspects sont secondaires, comme le respect des normes linguistiques notamment". (ADAMI, 2009, p.38-39).
} 
ter o domínio da língua e conhecimentos culturais do grupo pertencente a essa língua-alvo se torna, nesse contexto, um instrumento indispensável para a própria sobrevivência.

À vista dessas considerações e da minha experiência como professora- pesquisadora de língua de acolhimento no Módulo Acolhimento, elenco alguns possíveis objetivos e motivações do público-aprendente para aprender e adquirir a língua em contexto migratório. Classifico como possíveis objetivos e motivações, pois, como mencionei anteriormente, eles podem variar a depender do público-aprendente, no entanto, diante das observações e da recolha de dados que fazemos no Módulo Acolhimento, por meio de questionários aplicados aos aprendentes em cada curso que oferecemos, esses objetivos em grande parte têm se confirmado.

Figura 2 - Síntese dos objetivos e motivações do público-aprendente em aprender e adquirir a língua de acolhimento

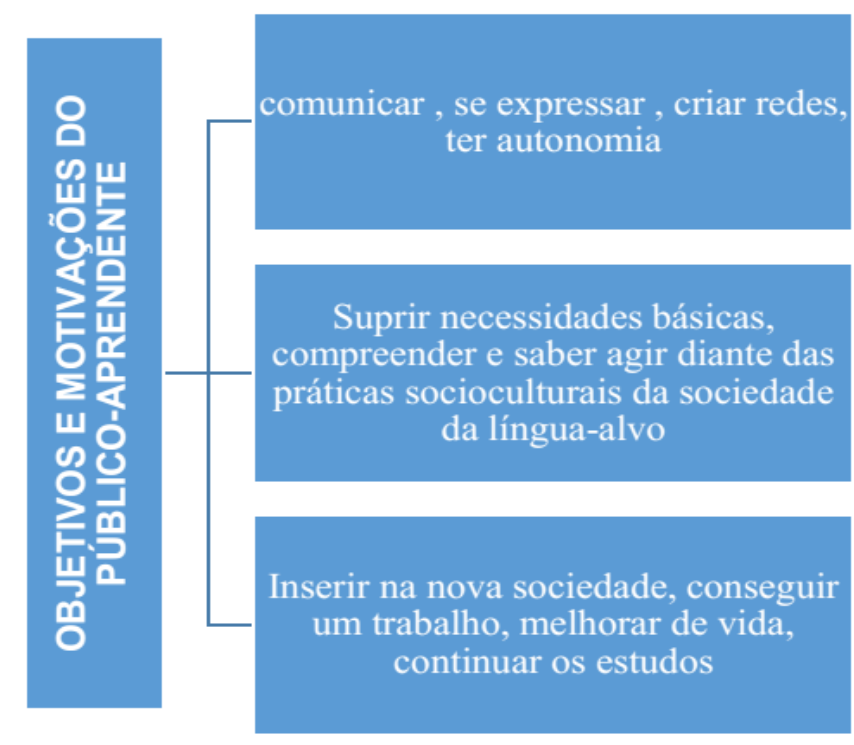

Fonte: Elaborado autora.

Diante de todos os fatores e das especificidades apresentados do contexto de ensinoaprendizagem da língua de acolhimento, dos possíveis objetivos e motivações do públicoaprendente e das concepções e instruções para a elaboração das materialidades de ensino de língua, o curso Módulo Acolhimento tem buscado desenvolver um ensino-aprendizagem de português que busca considerar e atender a todas essas condições de ensino e, para isso, tem construído e reconstruído suas próprias materialidades de ensino. 
Para construir e elaborar materialidades de ensino é preciso ter o conhecimento sobre a importância, a utilidade e a concepção dessas dentro do ensino de línguas. Dessa maneira, na próxima seção, descrevo mais detalhadamente sobre cada tipo de materialidade de ensino, conforme o modelo da Operação Global de Ensino de Línguas - OGEL.

\subsection{Materialidades de ensino de línguas}

Todo ensino, em geral, pressupõe objetivos e interesses que se implicam ou aplicam-se em um determinado contexto e para um determinado público. No ensino de línguas isso não é diferente. Para ensinar uma língua (materna, estrangeira ou segunda língua) é preciso fazer um mapeamento sobre o contexto de ensino-aprendizagem e sobre os focos de interesses e motivações dos interessados em aprenderem e adquirirem uma língua.

Tendo realizado esse mapeamento, o professor ou o profissional responsável pelo ensino poderá, então, construir ou planejar como e de que forma será desenvolvido o processo de ensino-aprendizagem da língua-alvo. Há diferentes maneiras e modelos sobre como elaborar um processo de ensino de línguas, no entanto, neste trabalho, por melhor me identificar e compreender, tomarei o modelo proposto por Almeida Filho, em $1993^{18}$.

No modelo da Operação Global de Ensino de Línguas (OGEL), o processo de ensino, de acordo com Almeida Filho (2013), é composto por quatro materialidades ou fases, tais como apresentadas a seguir: (1) o planejamento do curso, incluindo a reflexão; (2) a seleção ou produção de materiais que codificam a ação posterior das experiências; (3) a construção das aulas e de suas extensões (o método propriamente dito) e; (4) a avaliação de rendimento ou proficiência dos alunos. Para melhor visualizar e compreender o modelo da OGEL, apresento a última versão ampliada da representação gráfica proposta por Almeida Filho (2013, p. 32):

\footnotetext{
${ }^{18}$ A primeira versão publicada do modelo Operação Global de Ensino de Línguas (OGEL) foi em 1993, depois de dez ano, o autor amplia o modelo e faz uma nova publicação em 2013, no livro Dimensões Comunicativas no Ensino de Línguas (ALMEIDA FILHO, 2013). Edição comemorativa, corrigida e ampliada. Será essa versão mais atualizada que utilizarei.
} 
Figura 3 - Modelo Ampliado da Operação Global do Ensino de Língua

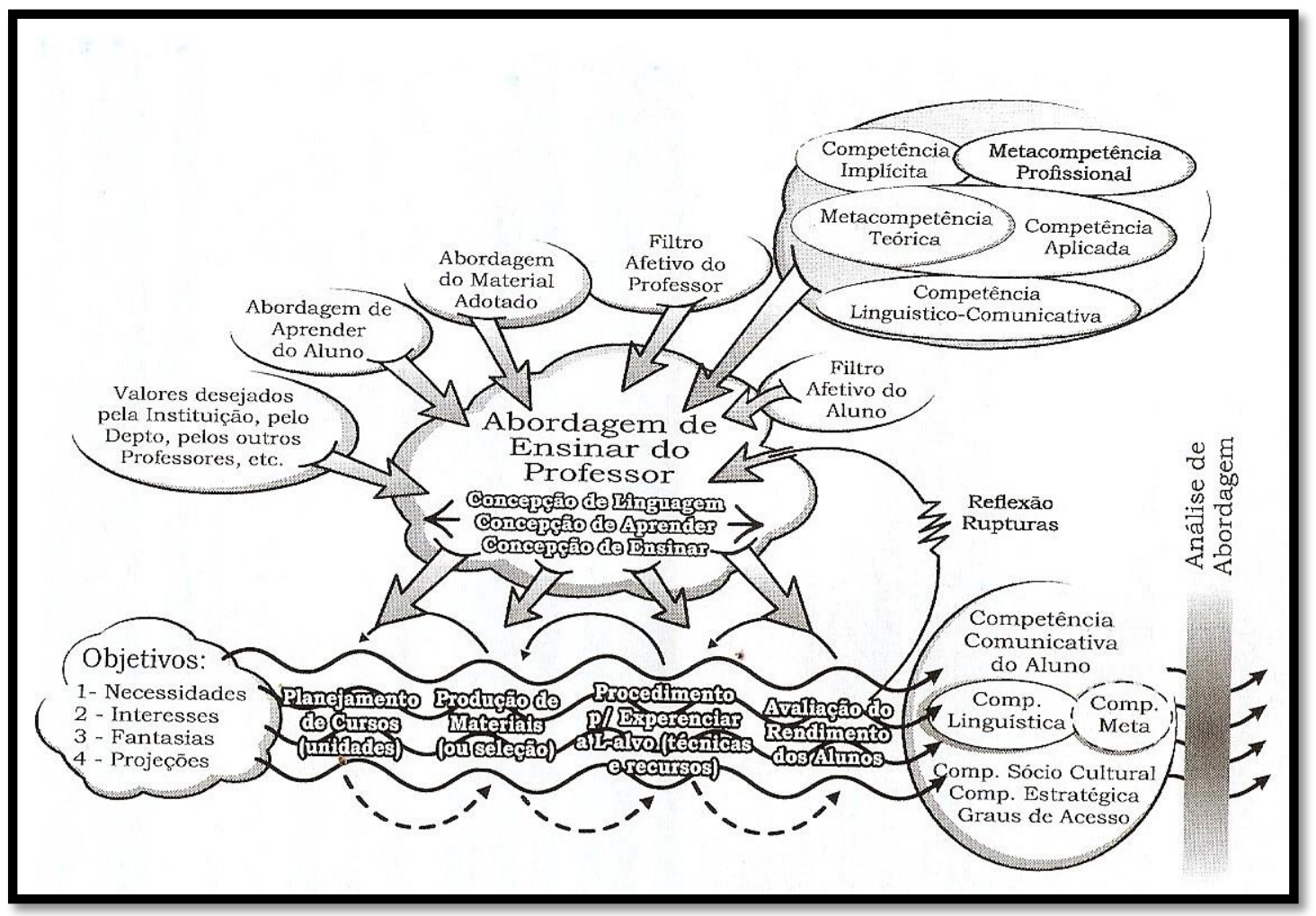

Fonte: Almeida Filho (2013, p.36)

Podemos observar, de acordo com o modelo, que a elaboração, assim como a natureza e a qualidade das quatro materialidades estão diretamente vinculadas à escolha de abordagem de ensinar do professor. Isto é, a abordagem guiará todo o processo de construção e seleção das fases/materialidades de ensinar.

Outro aspecto importante que é destacado por Almeida Filho (2013) mas que, no entanto, nesse modelo não está tão visível é sobre a ordenação das fases. Ele discorre que as fases ou materialidades podem ser trabalhadas ordenadamente (da esquerda para a direita), isto é, do planejamento à avaliação, quando se trata de um ensino novo. Já em outras situações, as alterações poderão ser iniciadas em qualquer das fases e dependendo dessas modificações serão provocados efeitos, proativo e retroativo, que contribuirão como "câmbios equilibradores" para ordenar as fases.

Dessa maneira, Almeida Filho (2013, p.31) frisa que as influências de uma etapa a outra estão previstas e orienta que "Quanto mais à direita ocorrer uma alteração mais efeito retroativo 
potencial ela possuirá sobre as dimensões anteriores. Quanto mais à esquerda maior potencial proativo conterá".

Nas próximas seções, apresento definições e características referentes às materialidades de ensino de línguas, que, conforme a OGEL, compõem o processo de ensinar línguas.

Destaco que esse conhecimento sobre o que constitui as materialidades é importante para o professor ou profissional de ensino, pois contribui para uma melhor e mais coerente construção/elaboração das materialidades.

\subsubsection{Abordagem}

A abordagem, segundo Almeida Filho (2013, p.30), pode ser compreendida, "como uma filosofia, um enfoque, uma aproximação, um tratamento, uma lida". Esse teórico realça que é a abordagem que imprime movimento e ação no processo de ensino, isto é, a abordagem é a força que norteia e dá consistência e rumo ao trabalho de ensino.

$\mathrm{Na}$ trajetória do ensino-aprendizagem de línguas há duas grandes abordagens: Abordagem Gramatical (AG) e Abordagem Comunicativa (AC). De acordo com as teorias de Almeida Filho (2011), para a abordagem gramatical (AG), o princípio organizador é a própria gramática. Esse ensino de língua será conduzido visando um aprendizado consciente da estrutura e de regras de funcionamento da língua que pressupõe, que conhecendo o funcionamento das regras da língua-alvo, o aprendente esteja preparado para fazer uso da língua de modo consciente. Nesta abordagem, o foco está na forma e seu ensino não precisa necessariamente ser contextualizado. Além disso, a abordagem gramatical deixa para segundo plano, ou até mesmo para nenhum plano, o desenvolvimento da competência comunicativa do aluno.

Ainda em consonância com o autor supracitado, para a Abordagem Comunicativa (abordagem mais recente), o princípio organizador é a comunicação construída na interação possível na língua-alvo. Esse ensino será conduzido com o objetivo de promover aquisição da língua por meio do desenvolvimento da competência comunicativa. O foco, nessa abordagem, está no sentido e seu ensino deve ser contextualizado e significativo para o(a)s aprendentes.

Há também uma terceira abordagem que se apresenta como híbrida, a qual Santos \& Almeida Filho (2012) chamam de Abordagem Gramatical Comunicativizada (AGC). De acordo com os autores, na AGC o ensino é conduzido, em primeiro plano, para obter conhecimento das regras gramaticais e, em seguida, praticá-las de maneira extensiva e controlada. Após esse momento, pode se possibilitar a prática desse conhecimento da língua com alguma liberdade 
em situações que se aproximam às propostas pela AC (SANTOS \& ALMEIDA FILHO, 2012, p.19).

A adoção ou escolha da abordagem do professor ou de um curso, conforme as perspectivas de Almeida Filho, é feita de acordo com um conjunto de disposições, de conhecimentos, de crenças, de filosofias sobre o que é linguagem humana, LE e sobre o que é aprender e ensinar uma língua-alvo que o professor ou o curso apresenta. Além disso, a escolha da abordagem deve levar em consideração a finalidade e objetivo do ensino que se pretende desenvolver.

Além dessas ponderações é importante saber, como o próprio teórico ressalta e o modelo da OGEL explicitamente registra, que a abordagem, sobretudo a do professor, pode sofrer influências de outras forças, tais como:

\footnotetext{
a abordagem de terceiros (colegas, superiores em posições fortes de liderança, autores de LDs, etc), filtros afetivos dos alunos em contato com o filtro afetivo da professora e a cultura de aprender dos alunos para orientar de maneira específica o processo ( a qualidade) do ensinar e eventualmente do aprender. (ALMEIDA FILHO, 1997, p.19).
}

Vale frisar que a escolha ou adoção de uma abordagem não se constitui como uma decisão rígida e acabada, pois ela pode se modificar durante o processo em consequência das tensões de outras forças que são mutáveis. Esse é um fato de acontecimento plausível, por isso, é importante o profissional de línguas ter o conhecimento desses processos para que saiba como lidar diante dessa situação, compreender essas mudanças para encontrar caminhos e recursos que possibilitem harmonizar as abordagens presentes dentro de uma sala de aula de modo que, na medida do possível, elas possam ser atendidas visando uma eficácia no ensinoaprendizagem.

Diante dos conhecimentos sobre a abordagem, passo para a explicação sobre o que se entende por planejamento de ensino e como elaborar um.

\subsubsection{Planejamento de ensino}

O planejamento de um ensino de línguas, de acordo com Nelson Viana (1997, p.29), constitui-se "como um processo reflexivo sobre e para a dinâmica de outro processo: o de ensino-aprendizagem de línguas".

Para Almeida Filho (1996), o planejamento representa uma operação formal de aprendizagem e ensino de língua e se caracteriza como: 


\begin{abstract}
processo ordenado e mapeado de decisões sobre inserções do conteúdo linguístico (amostras da língua-alvo, explicações, generalizações sobre aspectos sistematizáveis dessas amostras e automatizações eventuais) do tipo de processo que será engendrado no curso, e da reflexão sobre as decisões e resultados, das experiências mínimas na e sobre a língua-alvo num curso de língua apresentado em forma de unidades de ensino-aprendizagem. (ALMEIDA FILHO, 1996, p.02).
\end{abstract}

Resumidamente, no planejamento "trata-se de levantar objetivos, reconhecer direitos e deveres dos aprendizes e premeditar as unidades contendo conteúdos de ensino, processo de vivências e momentos de reflexão formadora”. (Glossário de Linguística Aplicada) ${ }^{19}$.

Tendo em vista os conceitos apresentados sobre o que é um planejamento, prossigo para as considerações sobre como elaborá-lo. Segundo Viana (1997), para a elaboração ou reelaboração de um planejamento, é necessário fazer uma "radiografia" em sentido amplo, isto é, ter conhecimento do contexto de ensino, das necessidades/interesses/motivações/ dos estudantes em aprenderem e adquirirem a língua-alvo, do número de aulas por semana, dos recursos físicos e humanos disponíveis.

Após esse mapeamento será possível estabelecer uma abordagem e assim o escopo dos objetivos do planejamento. Viana destaca que o planejamento abrange fases distintas que, interligadas, colaboram para a tarefa de organizar unidades de ensino. Essas unidades de ensino, segundo o autor, devem compor "planejamento de cursos e de currículos, e/ou a elaboração de materiais didáticos, ou ainda, a avaliação e adoção ou adaptação de materiais já prontos" (VIANA, 1997, p.29)

Outro aspecto ressaltado por Viana é sobre o planejamento a ser desenvolvido por um profissional que esteja mais diretamente ligado ao contexto de ensino, sendo este normalmente, o professor de línguas, que está inserido na realidade em que atua, sendo portanto, considerado o mais apto a desenvolver a tarefa, devido a sua proximidade com o contexto. No entanto, Viana (1997, p.36) frisa que esse profissional deve ter "um sólido embasamento acerca de pressupostos sobre ensino/aprendizagem de línguas" e conhecimentos sobre Linguística aplicada.

Diante do apresentado, elaborar ou reelaborar um planejamento de ensino/curso não é uma tarefa fácil, no entanto, necessária para que se produza um ensino coerente e significativo, além disso, Viana (1997, p.29) salienta que o planejamento se apresenta como "instrumento útil não só para a otimização do processo de ensino/aprendizagem de línguas mas também para a

19 Sociedade de Linguística Aplicada, Cultura Digital e Educação - SALA. Disponível em: <http://glossario.sala.org.br/>. Acesso em: 14 jan. 2017. 
obtenção de intravisões significativas sobre as diversas variáveis que se interligam na área educacional de língua estrangeira".

\subsubsection{Material Didático}

Tendo por base o modelo da OGEL, se elaborarmos o processo de ensino pela sequência ordenada do planejamento à avaliação, o material didático (MD), de acordo com o modelo, se encontra como a segunda materialidade no processo, sendo, portanto, produzido ou escolhido após a escolha da abordagem e a elaboração dos objetivos do planejamento. Tendo isso em vista, o material didático será elaborado ou selecionado de acordo com a abordagem adotada e com os objetivos propostos no planejamento. Dessa maneira, materiais didáticos podem ser compreendidos, segundo Almeida Filho (1994, p.44), como "codificações de experiências com uma língua-alvo organizadas em unidades de trabalho, acompanhadas ou não por notas e planos constantes de manual do professor e cadernos de exercícios".

Segundo o Glossário de Linguística Aplicada (GLOSSA), essas codificações se referem à compilação de ações ou insumos ${ }^{20}$, por meio de textos, figuras, fotos, falas, gestos, dentre outros, para experienciar a nova língua nas salas de aulas e nas suas extensões. E essas ações ou insumos serão produzidos ou selecionados conforme os objetivos estabelecidos no planejamento. Dessa maneira, os materiais didáticos, pela perspectiva de Vilaça (2009, p.07) têm a função básica de auxiliar o processo de ensino/aprendizagem, contribuindo "de formas variadas para que a aprendizagem seja bem-sucedida e, se possível, rápida, prazerosa e significativa".

Tendo em vista no que se constitui o material didático e qual a sua função, é pertinente saber como elaborar um material didático. Leffa (2003, p.15) orienta que a produção de material didático de ensino é "uma sequência de atividades que tem por objetivo criar um instrumento de aprendizagem". Essa sequência de atividades, de acordo com o autor, deve envolver pelo menos quatro momentos: (1) análise, (2) desenvolvimento, (3) implementação e (4) avaliação.

Descreverei, resumidamente, de acordo com a proposta de Leffa (2003), as etapas do processo de elaboração do material didático:

1. Análise: refere-se ao início da produção do material didático e se constitui na investigação das necessidades e objetivos do público-aprendente em aprender e adquirir a

\footnotetext{
${ }^{20}$ De acordo Glossário de Linguística Aplicada (GLOSSA), insumo é “toda manifestação de linguagem na línguaalvo que pode, eventualmente, se tornar competência comunicativa na interlíngua". Disponível em: <http://glossario.sala.org.br/>. Acesso em: 14 jan. 2017.
} 
língua-alvo. A análise deve-se atentar aos objetivos, aos anseios, às expectativas e à faixa etária dos aprendentes, assim como ao nível de conhecimento do conteúdo a ser desenvolvido.

2. Desenvolvimento: realizada a análise das necessidades, é preciso definir os objetivos. Com a definição clara dos objetivos essa etapa se direciona a selecionar os conteúdos e as atividades que serão desenvolvidos no material didático com o intuito de atender aos objetivos.

3. Implementação: essa etapa simplificadamente é o momento da aplicação do MD. Leffa se preocupou em destacar nessa etapa três situações que podem acontecer: (1) o material vai ser usado pelo próprio professor, (2) o material vai ser usado por outro professor, (3) o material vai ser usado diretamente pelo aluno sem presença de um professor. Ele alerta que cada caso solicita uma estratégia diferente de implementação. No primeiro caso "a implementação dá-se de modo intuitivo, complementada pelo professor, que, oralmente, explica aos alunos o que deve ser feito" (2003, p.34), no segundo caso, "há necessidade de instruções de como o material deve ser apresentado e trabalhado pelos alunos" (2003, p.35) e, no último caso, conforme salienta, que é o mais difícil e precisa se ter mais cuidado, há dois grandes desafios: o primeiro é estabelecer contato com o aluno oferecendo nem menos nem mais do que ele precisa e o segundo desafio é “tentar prever o que pode acontecer" (2003, p.35).

4. Avaliação: essa etapa pode ser realizada de maneira formal e informal. A primeira, de acordo com o autor, "pode ser feita por consultoria de um especialista ou por questionários e entrevistas com os alunos" (2003, p.37) e a segunda pode ser realizada, normalmente, por um único professor que aplica o material e analisa esse processo obtendo conclusões que resultaram, quando necessário, na reformulação. Leffa (2003) frisa que o objetivo da pilotagem é mostrar o que pode permanecer e o que precisa ser melhorado e isso só é possível quando o material é testado com o público-aprendente para o qual se destina.

Vale ressaltar que as etapas apresentadas de elaboração para um MD não devem ser concebidas para serem rígidas e acabadas, mas para atender, na medida do possível, aos objetivos do ensino e do público-aprendente, podendo e estando sujeitas, portanto, a sofrer modificações ou reelaborações durante o processo de aplicação do material ou mesmo ao final desse. 
Dessa maneira, o material didático não é um produto pronto e finalizado, mas um processo em contínua mudança tendo por finalidade, conforme Vilaça (2009, p.07) afirma, contribuir como mais um recursos para que a aprendizagem seja "bem-sucedida e, se possível, rápida, prazerosa e significativa".

\subsubsection{Método}

Segundo Vilaça, há variadas concepções e compreensões sobre o que é um método, as quais são concebidas de acordo com a natureza da área de pesquisa. Neste trabalho apresento a concepção proposta por pesquisadores da área da linguística aplicada. Iniciarei com a definição atribuída pelo Glossário de Linguística Aplicada (GLOSSA) que descreve método como sendo:

conjunto de procedimentos para fazer os aprendentes experienciarem a nova língua. Sob essa rubrica do método estão as técnicas que podemos reconhecer e os recursos previstos para apoiar e intensificar as experiências que se criarão nas salas de aula e nas extensões delas. (Disponível em: http://glossario.sala.org.br/).

Pela mesma perspectiva do GLOSSA, Patrocínio (1997, p.60) discorre que método é "todo o conjunto de experiências, auxiliadas ou não por recursos áudio-visuais, com e na línguaalvo, criadas e vivenciadas com o intuito de desenvolver no aprendiz competência linguísticocomunicativa dentro e fora da sala de aula". Para Almeida Filho (2010), em entrevista dada ao Portal do Professor ${ }^{21}$ explica que método "pode se referir a material didático ou a um dado conjunto de procedimentos de ensino e, ou aprendizagem propriamente ditos".

Dessa forma, diante das definições apresentadas, compreenderei método como "o conjunto de experiências vivenciadas no dia a dia da sala de aula e nas suas extensões" (PATROCÍNIO, 1997, p.61). Segundo Vilaça (2008), baseando-se nas teorias de Anthony (1963) método é desenvolvido:

\footnotetext{
na prática docente por meio de diferentes técnicas. As técnicas são, portanto, os recursos, as estratégias e as atividades práticas empregadas pelo professor, na sala de aula, para que o método atinja a sua realização concreta no contexto pedagógico. (VILAÇA, 2008, p.77).
}

Tanto Vilaça quanto outros teóricos, tais como Almeida Filho, Patrocínio, dentre outros, concordam que o método é desenvolvido por variadas técnicas que são também denominadas,

\footnotetext{
${ }^{21}$ Entrevista disponibilizada em: <http://portaldoprofessor.mec.gov.br/conteudoJornal.html?idConteudo=1068>. Acesso em: 28 dez. 2016.
} 
segundo Patrocínio (1997), de procedimentos, no entanto, a autora frisa, que nem todos os procedimentos se constituem em técnicas.

É por meio do método, escolhido de acordo com a abordagem norteadora e com os objetivos do planejamento, que seleciono, elaboro e concretizo dinâmicas de ensino tais como atividades, tarefas, jogos, dinâmicas para poder experienciar a língua-alvo durante as aulas e nas suas extensões. Essas dinâmicas de ensino são conduzidas por técnicas que envolvem certos procedimentos.

Aproveito nessa seção para destacar, de acordo com a perspectiva de Patrocínio (1997), o que se compreende por cada termo que compõe a dinâmica de ensino mencionada anteriormente. Início pelo termo "atividade" que "seria denominação geral das experiências vivenciadas dentro e fora de sala de aula" (PATROCÍNIO, 1997, p.61). Já o termo "tarefa", Patrocínio (1997, p.61), guiando-se pela concepção de Prabhu (1987), discorre que é como “um tipo de atividade que demanda que os aprendentes cheguem a um resultado a partir de uma dada informação, através de algum processo de pensamento controlado e regulado pelo professor”. Ela frisa que toda tarefa é uma atividade, porém, nem toda atividade pode ser concebida como uma tarefa. Referente ao termo “jogo”, conforme Patrocínio (1997), se caracteriza como uma atividade lúdica organizada por um conjunto de regras. Há também o termo "projeto" que é uma "atividade temática em que os aprendentes são levados a aprofundar conhecimento para apresentação posterior de um trabalho final” (PATROCÍNIO, 1997, p.61).

Dessa maneira, o professor precisa ser orientado por um método, técnicas e procedimentos para conduzir as aulas, os materiais didáticos e as dinâmicas de ensino, pois é por meio dele que as ações planejadas e codificadas para experienciar a língua-alvo são desenvolvidas e concretizadas.

Faço questão de relembrar que há diversos métodos, no entanto, conforme menciona Almeida Filho (2010), em entrevista ao Portal do Professor, “o método mais apropriado para conduzir um ensino são os de cada professor, desde que ele reconheça qual o método ele tem na prática e a qual abordagem ele pertence".

À vista disso, é importante que o professor faça um exame contínuo sobre os métodos, técnicas e procedimentos dos quais tem se utilizado para concretizar, desenvolver as dinâmicas de ensino dentro e fora de sala de aula. 


\subsubsection{Avaliação}

Avaliar, de acordo com definição dada por Scaramucci (1997, p.78) é "um meio de que dispõem o professor e a escola para a consecução de seus objetivos e contínuo aprimoramento do processo de ensino/aprendizagem”. De acordo com a autora, nesse contexto, a avalição cumpre a seguinte função:

coletar informações de forma sistemática, para tomar decisões; informações sobre a prática para a prática, e, portanto, um processo dinâmico de tomada de consciência para mudar quando necessário, para reverter, para reconsiderar, para redimensionar a ação e sua direção. (SACARAMUCCI, 1997, p.78).

Reconhecendo a importância da avaliação e a sua função é preciso refletir e planejar como a avaliação será conduzida no processo de ensino-aprendizagem, de maneira que esteja coerente com a abordagem adotada e seja eficaz para auxiliar e avaliar todo o processo de ensino-aprendizagem.

De acordo com Scaramucci (1997), há inúmeras maneiras de avaliar, que estão ligadas a determinadas visões e teorias da linguística, tais como a formalista ou estruturalista, a funcionalista e a sociolinguística-integrativa, dentre outras. Resumidamente, de acordo com autora, a formalista surgiu no começo dos anos 1960 e objetiva avaliar de maneira mais sistematizada, e separadamente, os componentes linguísticos e habilidades, por meio de testes elaborados por itens objetivos de múltipla escolha que permitem obter dados quantitativos e objetividade na correção.

A avaliação funcionalista veio ao final dos anos 1960 com o objetivo, conforme Scaramucci (1997), de propor uma avaliação com uma visão mais funcional, isto é, de modo a avaliar a função da linguagem na comunicação em situações reais, avaliar aspectos da linguagem em seu uso e não mais avaliar somente formas gramaticais.

E, por último, nos anos 1980, junto com o movimento comunicativo, desenvolveu-se a avaliação sociolinguística-integrativa que não mais enfatiza aspectos e habilidades linguísticas isoladas, mas uma combinação de habilidades. Nessa avaliação, de acordo com a autora, "os testes passam a incluir tarefas comunicativas, que exigem uma representação mais direta da língua e que tem, portanto, uma função comunicativa autêntica” (SCARAMUCCI, 1997, p. 82).

Como se pôde observar, a avaliação está diretamente ligada à abordagem de ensino. Vale destacar que, conforme as abordagens de ensino vão se modificando, as formas de avaliar 
também. Dessa maneira, de acordo Scaramucci (1997, p. 82) “não há como pensar no ensinoaprendizagem sem se pensar em avaliação”.

Considerando essa afirmação, ao propor um ensino-aprendizagem de línguas é necessário, de acordo com a abordagem adotada, planejar como esse processo avaliativo será conduzido.

Na OGEL, a avaliação é colocada como a quarta materialidade, dando a impressão de ser a última etapa a ser realizada, no entanto, Scaramucci (2006) faz uma ressalva interessante quando diz que:

\footnotetext{
a avaliação não é apenas central ao processo de ensino e de aprendizagem; é sobretudo, o elemento integrador entre os dois processos e, como tal, deve subsidiá-los desde o seu início, e, portanto, não deveria ser tratada como uma etapa final independente, como aparece em muitos modelos de ensino-aprendizagem (por exemplo, Almeida Filho, 1993). Pensar na avaliação desde o início do processo é fundamental na definição não apenas do ponto de chegada ou dos objetivos a serem alcançados, mas, sobretudo, do de partida. (SCARAMUCCI 2006, p. 52).
}

Tendo em vista a ressalva feita por Scaramucci, podemos considerar que a avaliação não é apenas um instrumento que deve ser realizado somente ao final do processo de ensino, mas deve estar presente em todas as suas etapas, seja por meio da aplicação contínua de instrumentos formais (provas, testes) ou por instrumentos informais, com a observação contínua do professor durante as aulas e suas extensões.

Dessa forma, pensar na avaliação ao conceber um ensino-aprendizagem de língua, e durante a condução desse ensino, é imprescindível, pois, ela contribuirá com todo o processo como "um mecanismo propulsor de mudanças no processo de ensino-aprendizagem" (SCARAMUCCI, 2006, p. 52).

Ter o conhecimento das materialidades proposta pela OGEL é de extrema importância para o profissional de línguas, no entanto, esse profissional precisa de uma formação e de uma prática para saber construir e conduzi-las. Na seção seguinte, discorro brevemente sobre a formação docente.

\subsubsection{Formação docente do professor de português como língua estrangeira}

Como apresentado no início desse capítulo, o ensino de português para estrangeiros no Brasil e no mundo tem ganhado visibilidade, assim como a necessidade de formação de profissionais nessa área também. 
Cotidianamente, com ênfase no ensino de línguas estrangeiras, é possível perceber o descaso que há para com essa área e para com os profissionais formados nesse âmbito. Nota-se escolas contratando pessoas que não têm formação no ensino-aprendizagem de línguas, mas que, por terem conhecimentos linguísticos e domínio de uso de uma determinada língua estrangeira, seja porque estudaram ou moraram em outro país, ou até mesmo porque são nativos da língua-alvo, acreditam poder exercer a profissão de professor de línguas. Esse descaso acaba por alargar as precariedades que ainda se apresentam no ensino-aprendizagem de línguas estrangeiras.

Por isso é necessário, primeiramente, reconhecer a necessidade de uma formação docente para o profissional de línguas e pleitear mais investimentos financeiros e políticos nessa área. A formação docente de um professor de língua normalmente se desenvolve em uma graduação de Letras (licenciatura), por meio das disciplinas: prática de ensino e estágio supervisionado.

Segundo Leffa (2001 apud MAIA \& MENDES, 2009), para se desenvolver uma boa formação docente de um professor de línguas deve-se atentar para quatro aspectos: conhecer teorias sobre o processo de ensino e aprendizagem de línguas, realizar uma prática, conduzir uma pesquisa e desenvolver uma política de atuação.

O conhecimento da teoria colabora para compreender a dimensão do que vem sendo realizado, discutido e pesquisado no domínio do ensino de línguas, possibilitando, assim, acesso a fundamentos e abordagens que apresentem inúmeras concepções de língua, linguagem, língua estrangeira, ensino e aprendizagem.

O contato com a teoria é de extrema importância para que se conheçam os constituintes da Operação Global de Ensino de Línguas (OGEL), como as diversas abordagens, as metodologias existentes, as discussões sobre os diferentes processos de ensino-aprendizagem, as políticas de educação e de atuação no ensino de línguas.

Além disso, o conhecimento teórico possibilita a construção dos saberes e a própria identidade profissional, pois, por meio dele, podemos desenvolver ideias, obtendo um respaldo teórico de outros profissionais que partilham das nossas reflexões ou então daqueles que possuem ideias diferentes. É nessa via de mão dupla, de assemelhar ou diferenciar, que construímos ou mesmo reconstruímos saberes necessários à formação docente.

À vista disso, para Leffa (2001), ter um conhecimento da teoria, ajuda a desenvolver uma política de atuação assim como uma emancipação do professor para mudar, interferir se necessário, no currículo de ensino e aprendizagem de línguas. 
A prática, de acordo com Leffa (2001), por outro lado, possibilita que os conhecimentos apreendidos na teoria possam ser aplicados, testados, vividos e, assim, concretizados ou não. Ou seja, por meio dessa prática, o aprendente poderá de modo vívido compreender o que até então ficava em uma esfera de possibilidades e discussões em sala de aula com professores e alunos. É nesse momento que a formação docente começa a se deslocar do plano do desejado e idealizado, para o do necessário e possível.

Desse modo, conforme Tardif (2003), são os saberes práticos ou experiências que possibilitarão aos profissionais de língua conceberem os modelos de excelência profissional dentro de sua profissão. Isto é, a prática não somente possibilitará validar ou não o que foi passado pelas teorias, mas também permitirá uma avaliação e mobilização de outros saberes.

No que se refere à pesquisa, que também faz parte da formação docente, é importante ressaltar que ela permite a reflexão e o entrelaçamento da prática com a teoria. É esse momento que nos proporciona uma abertura para investigar, contrapor as nossas ideias com às teorias e com a própria prática, refletir sobre a maneira como temos orientado os nossos estudos e, dessa forma, tentar aprimorá-los, além de enriquecer nossas experiências e currículos. Assim, a pesquisa é necessária para o professor que almeja uma formação docente atualizada e reflexiva ${ }^{22}$.

Essa formação docente deve contribuir para desenvolver no professor uma política de atuação, que se traduz no modo como o profissional, ou seja, o professor de línguas, desenvolverá uma consciência sobre ensinar e aprender. De acordo com Almeida Filho (2012, p. 11) "professores e alunos não ensinam e aprendem a esmo". Ou seja, todos são conduzidos a ensinar como ensinam e a aprender como aprendem, de acordo com as visões que possuem, de acordo com a cultura de ensinar e aprender que cada indivíduo possuiu ou constrói, de acordo com as suas abordagens ${ }^{23}$.

Remetendo ao conceito de Paulo Freire (1996, p.47), ensinar "não é transferir conhecimento, mas criar a possibilidade para a sua própria produção ou a sua construção". Dessa forma, ensinar uma língua não consiste somente em "despejar" ou mesmo "depositar" no aprendente conteúdos linguísticos e gramaticas, mas possibilitar um caminho significativo de conhecimento e de uso dessa língua.

\footnotetext{
${ }^{22}$ Ao me referir a uma "formação atualizada e reflexiva", tenho a dizer que essa se torna possível e necessária ao realizar uma pesquisa, pois a pesquisa propicia o contato com as novas demandas de ensino-aprendizagem, assim como possibilita, pelo próprio ato de "pesquisar", refletir sobre as nossas experiências como docente.

${ }^{23}$ Abordagem, para Almeida Filho $(1997,2012)$ é um conjunto de disposições de conhecimento conceitos de linguagem, de ensinar e de aprender.
} 
Portanto, para ensinar uma língua seja materna, estrangeira ou segunda língua é imprescindível uma formação docente, uma concepção pré-definida sobre o que é ensinar e aprender uma língua e conhecimentos sobre os processos que envolvem o ensino-aprendizagem de línguas.

Considero que as teorias e as discussões apresentadas neste capítulo teórico são relevantes para melhor conhecer, compreender e refletir sobre o contexto, as especificidades do ensino-aprendizagem da língua de acolhimento e as materialidades de ensino que compõem o modelo da OGEL. No próximo capítulo, discorro sobre a metodologia eleita como a mais adequada para conduzir esta pesquisa e apresento o contexto de pesquisa e o perfil do grupo analisado. 


\section{CAPÍTULO III: METODOLOGIA DA PESQUISA}

Neste capítulo, discorro sobre o paradigma adotado nessa pesquisa, assim como a metodologia aplicada, os instrumentos utilizados para a coleta de dados, o cenário de pesquisa, o grupo pesquisado, as informações sobre a professora-pesquisadora, o procedimento adotado para a análise de dados e as considerações éticas que guiaram os procedimentos e desenvolvimento da pesquisa relatada nesta dissertação.

\subsection{A escolha do paradigma qualitativo}

Chizzotti (2006, p.24-25), afirma que uma pesquisa deve pressupor "implicitamente ou explicitamente, uma metodologia, os pressupostos epistemológicos e a concepção de realidade que a pesquisa assume". Ou seja, para realizar uma pesquisa, de acordo com a autora, temos que pensar em quatro questões: Qual é o problema a ser pesquisado? Qual é a concepção de realidade adotada para a pesquisa? Que teoria de conhecimento melhor orientará o seu desenvolvimento? Como e quais são os métodos que conduzirão esse trabalho?

Atualmente, de um modo geral, existem dois paradigmas de pesquisa, sendo eles: quantitativo e qualitativo. A fim de descrever de forma resumida o que caracteriza os dois modelos de pesquisa, elaborei uma síntese de acordo com os escritos de Laville \& Dionne (1999).

Quadro 2 - Resumo dos paradigmas de acordo com Laville \& Dionne (1999)

\begin{tabular}{|l|l|l|}
\hline Procedimentos & \multicolumn{1}{|c|}{ Paradigma Qualitativos } & \multicolumn{1}{c|}{ Paradigma Quantitativos } \\
\hline $\begin{array}{l}\text { Objeto de } \\
\text { estudo }\end{array}$ & Seres humanos & $\begin{array}{l}\text { Experimentais, rígidos, quantitativos } \\
\text { e deterministas }\end{array}$ \\
\hline Fatos & $\begin{array}{l}\text { Não se repetem e as ações e reações não } \\
\text { são quantificáveis }\end{array}$ & Repetitivos e quantificados \\
\hline Resultados & $\begin{array}{l}\text { Relativos } \\
\text { É um ator envolvido com o objeto de } \\
\text { estudo }\end{array}$ & $\begin{array}{l}\text { Pero observador e separado do } \\
\text { objeto de estudo }\end{array}$ \\
\hline Pesquisador & \begin{tabular}{l} 
Procisos \\
\hline
\end{tabular} &
\end{tabular}

Fonte: Elaborado pela autora. 
Esses dois paradigmas de pesquisa, embora possuam berços diferentes, fazem-se presentes e podem ser aplicados tanto pelas ciências naturais quanto pelas humanas. Acerca disso, Laville \& Dionne (1999) ponderam que

\begin{abstract}
A partir do momento em que a pesquisa centra-se em um problema específico, é em virtude desse problema específico que o pesquisador escolherá o procedimento mais apto, segundo ele, para chegar à compreensão visada. Poderá ser um procedimento quantitativo, qualitativo, ou uma mistura de ambos. O essencial permanecerá: que a escolha da abordagem esteja a serviço do objeto de pesquisa, e não o contrário, com o objetivo de daí tirar, o melhor possível, os saberes desejados. (LAVILLE \& DIONNE, 1999.p.43).
\end{abstract}

Dessa forma, a escolha do modelo de pesquisa dependerá do problema e da finalidade da pesquisa, bem como, segundo Chizzotti (2006), dos pressupostos epistemológicos, da concepção de realidade que o pesquisador assume e da metodologia.

É relevante ressaltar que não há um paradigma melhor ou pior que o outro, há aquele que pode ser mais apropriado ou menos apropriado a determinada pesquisa, por isso, considero importante o pesquisador conhecer os dois paradigmas de pesquisa existentes, pois assim, poderá eleger o que melhor se aplica a sua pesquisa. Neste caso, a pesquisa aqui relatada se configurou pelo caráter qualitativo de cunho interpretativista.

A pesquisa qualitativa, conforme Denzin \& Lincoln (2006), ganha um significado diferente a cada momento histórico em que é inserida. Dessa forma, há variadas definições e descrições sobre o modelo qualitativo. No entanto, para este estudo tomei como norte a seguinte definição:

\begin{abstract}
A pesquisa qualitativa é uma atividade situada que localiza o observador no mundo. Consiste em um conjunto de práticas materiais e interpretativas que dão visibilidade ao mundo. Essas práticas transformam o mundo em uma série de representações, incluindo as notas de campo, as entrevistas, as conversas, as fotografias, as gravações e os lembretes. Nesse nível, a pesquisa qualitativa envolve uma abordagem naturalista, interpretativa, para mundo, o que significa que seus pesquisadores estudam as coisas em seus cenários naturais, tentando entender, ou interpretar, os fenômenos em termos dos significados que as pessoas a eles conferem (DENZIN \& LINCOLN, 2006, p.17).
\end{abstract}

Embasada nessa definição, a presente pesquisa se inseriu na vertente qualitativa de caráter interpretativista, pois se desenvolveu sob a concepção de uma realidade naturalista e múltipla de uma sala de aula, ou seja, em um cenário natural. Teve como objeto de estudo seres humanos (grupo de aprendentes: refugiados e imigrantes), suas relações afetivas, culturais e sociais e foi conduzida por uma epistemologia interpretativa, sujeita, dessa forma, a valores humanos. 
Além disso, a pesquisadora não foi apenas uma observadora, mas se envolveu com seu objeto de estudo, o que caracteriza, conforme Laville \& Dionne (1999), a pesquisa qualitativa. Dessa forma, esse estudo se guiou pelo modelo qualitativo de cunho interpretativista, como já destacado, por considerá-lo mais apropriado ao seu desenvolvimento.

\subsubsection{Método de pesquisa: estudo de caso}

A seleção do instrumental metodológico, segundo Marconi e Lakatos (2003) está diretamente relacionada com o problema a ser estudado, ou seja, a escolha dependerá dos diversos fatores que envolvem a pesquisa tais como: o objeto de estudo, os recursos financeiros, a equipe humana e os outros elementos que poderão surgir no campo da pesquisa. Além disso, esses autores discorrem sobre o seguinte: "nas investigações, em geral, nunca se emprega apenas um método ou uma técnica, mas todos os que forem necessários ou apropriados para determinado caso" (MARCONI e LAKATOS, 2003, p.163).

Flick (2004) também afirma que existe uma enorme variedade de métodos específicos disponíveis e que cada um parte de uma distinta premissa em busca de objetivos distintos. Assim, a escolha de cada método de pesquisa deve se fundamentar na compreensão específica de seu objeto de estudo.

Sob o abrigo do paradigma qualitativo, Chizzotti (2006) pondera que há variados métodos de pesquisa tais como: pesquisa clínica, pesquisa participativa, etnografia, pesquisa participante, pesquisa-ação, teoria fundamentada, estudos culturais, entre outros. Freebody (2003) discorre que, na pesquisa qualitativa, principalmente na área da educação, há três metodologias que podem ser empregadas: etnografia, estudo de caso e pesquisa-ação. Dessa forma, o paradigma qualitativo não elege uma única prática metodológica específica, mas a mais apropriada, haja vista, a área de estudo, o objeto a ser estudado e os fatores que o envolvem.

Para o desenvolvimento dessa pesquisa, o método estudo de caso foi escolhido como o mais apropriado para a sua condução, pois esse estudo objetiva investigar, analisar e descrever um fato em particular no contexto em que ele ocorre. Além disso, as percepções geradas desse caso podem ser estendidas a outros casos, pelo que Stake (1994, p. 243) chama de "generalizações naturalísticas". No sentido de melhor compreender o método empregado nesta pesquisa, apresento algumas características e definições atribuídas ao estudo de caso.

De acordo com André (1995/2001), são características do estudo de caso: 
(1) quando se está interessado numa instância em particular, isto é, numa determinada instituição, numa pessoa ou num específico programa ou currículo; (2) quando se deseja conhecer profundamente essa instância particular em sua complexidade, em sua totalidade; (3) quando se estiver mais interessado naquilo que está ocorrendo e no como está ocorrendo do que nos seus resultados; (4) quando se busca descobrir novas hipóteses teóricas, novas relações, novos conceitos sobre um determinado fenômeno; e (5) quando se quer retratar o dinamismo de uma situação numa forma muito próxima do seu acontecer natural (ANDRÉ, 1995/2001, p. 51-52).

Sob perspectiva de Yin (2001, p.32) o estudo de caso é "uma investigação empírica que investiga um fenômeno contemporâneo dentro de seu contexto da vida real, especialmente quando os limites entre o fenômeno e o contexto não estão claramente definidos”. Esse autor ressalta que essa investigação empírica que investiga o caso ou os casos, deve abordar questões "como" ou "por quê" relativamente ao fenômeno de interesse.

Para Merriam (1998, p 27) o estudo de caso se constitui em "uma descrição intensa, holística, bem como uma análise de um fenômeno limitado, como um programa, uma instituição, uma pessoa, um processo ou uma unidade social”. A autora ressalta que o estudo de caso tem como característica principal a delimitação do objeto de estudo, isto é, o caso em si, tendo por objetivo "descrever o fenômeno em profundidade", uma vez que o caso foi escolhido por se evidenciar em um fenômeno interessante, que motivou o pesquisador a querer ter uma compreensão mais ampla e detalhada sobre ele.

Na mesma linha de pensamento da autora supracitada, Moura filho (2005) compreende estudo de caso como sendo uma investigação detalhada de um objeto ou fenômeno, ressaltando que no caso das pesquisas educacionais o estudo de caso pode se caracterizar como sendo:

simples quanto complexo e envolver um (a) único (a) aluno (a), uma turma da escola, todas as turmas da escola e, até mesmo, o processo de mobilização da comunidade escolar com vistas à melhoria de processos de ensino-aprendizagem. (MOURA FILHO, 2005 p. 106).

Embora as definições sobre estudo de caso, muitas vezes, não entrem em consenso, as apresentadas neste estudo alinham-se, no sentindo de investigar um caso, um fenômeno em uma instância particular, de forma a analisá-lo de maneira detalhada, em complexidade e profundidade.

Freebody (2003, p.81) afirma que "pesquisadores de várias áreas profissionais e práticas usam estudo de caso como uma forma de conduzir e disseminar a pesquisa para impactar a prática, e para refinar a forma como a prática é teorizada". Além disso, o autor ressalta que os defensores da metodologia de estudo de caso destacam que professores estão sempre ensinando 
um assunto, com alunos específicos, em lugares e condições particulares que moldam significativamente a prática de ensinar e aprender.

Dessa forma, o estudo de caso possibilita, de acordo com Freebody (2003), colocar em pauta um questionamento no qual tanto pesquisadores quanto educadores podem refletir sobre pontos específicos da prática educacional. É o caso deste estudo, em que me proponho refletir e analisar sobre determinada prática que tem sido desenvolvida em um grupo específico de aprendentes de língua portuguesa em contexto de imigração e refúgio.

Para desenvolver um estudo de caso é necessário seguir procedimentos metodológicos que podem variar de acordo com os teóricos e com os objetivos do estudo, ou seja, também não há um consenso e uma padronização. Nesta dissertação, para melhor atender ao tipo de estudo de caso que me proponho desenvolver, tomo por procedimento metodológico de estudo de caso sugerido por Freebody (2003, p. 83), que o divide em cinco partes.

A primeira refere-se à definição da pergunta de pesquisa, pois é importante ter um entendimento prévio do domínio central do questionamento da pesquisa. Freebody (2003) ressalta que essa primeira fase preparatória e de definição deve também englobar uma análise inicial dos fatores políticos, históricos, culturais e pessoais que moldaram o caso em questão.

A segunda parte relaciona ao design do planejamento da coleta de registros, das informações e na especificação do tipo de caso, isto é, se esse caso é considerado representativo de uma determinada dimensão, como uma região geográfica, uma composição cultural, nível socioeconômico, etc. Esse momento serve para especificar, determinar o caso em si, como, por exemplo, se o autor menciona que o estudo pode ser de um único distrito escolar e de uma escola naquele distrito, de um professor específico, ou um pai de aluno de uma determinada comunidade. É importante definir o caso, pois cada caso pode envolver níveis múltiplos de análises, em que cada nível constitui um caso.

A terceira refere-se ao campo, a coletar os registros e armazená-los de forma precisa e sistemática, pois conforme Freebody (2003), os fragmentos de memória são desencadeados em determinados momentos durante a interpretação de dados e para recuperar tais fragmentos de forma acurada e eficiente demanda-se uma armazenagem sistemática e um sistema de recuperação de dados.

A quarta fase concerne à análise de dados, ao uso de formas variadas de coleta de dados e procedimentos analíticos. Freebody (2003, p. 83) destaca que isso é feito com o objetivo de prover ao pesquisador a oportunidade de: comparar e contrastar interpretações; expandir a relevância do projeto desenvolvendo achados e interpretações não previstas; e explorar achados que são anômalos ou em discordância com as impressões e hipóteses originais. 
E a quinta, e última fase, direciona-se ao relatório, ou seja, a reportar, compartilhar as experiências do estudo de caso de maneira coerente para o leitor.

Vale frisar que, neste estudo de caso, não foi colocada a modalidade análise documental, conforme sugerido pelos autores Bogdan \& Biklen (1998 apud MOURA FILHO, 2005, p. 111), porque não consegui encontrar estudos mais aprofundados dessa modalidade e também porque os documentos que foram utilizados neste estudo se caracterizam como um dos instrumentos de coleta de dados e não foram o foco central da pesquisa. Além disso, Moura filho (2005, p.112) ressalta "que divisão do estudo de caso em categorias é puramente didática. De fato, nada pode nos garantir que um estudo de caso seja ortodoxamente do tipo história de vida ou documental, por exemplo".

Entretanto, ressalto que neste estudo, utilizei-me de procedimentos da análise documental para tratar e interpretar as informações, visando compreender os dados gerados por esse instrumento, isto é, apropriei-me de conhecimento da análise documental para a apreensão, compreensão e análise dos documentos e não como o caso em si.

Dessa maneira, tendo em vista, o caso, os objetivos propostos na pesquisa aqui relatada, o mais adequado foi desenvolver um estudo de caso qualitativo de cunho interpretativista.

\subsection{O contexto da pesquisa}

De acordo com André (1995, p.19) os estudos de caso enfatizam "a interpretação em contexto", ou seja, uma compreensão mais completa do objeto só é possível levando em conta o contexto em que está inserido.

O contexto geral em que esta pesquisa se inseriu foi apresentado no capítulo I com o breve panorama do fluxo imigratório no Brasil. Já na próxima subseção, descrevo o contexto em que foi realizada a pesquisa relatada nesta dissertação. Esse contexto mais específico, por questões mais didáticas e para evitar repetições de termos, nomeio de cenário de pesquisa.

\subsubsection{Cenário da pesquisa: Módulo Acolhimento: curso de português para refugiados e imigrantes}

A pesquisa qualitativa à qual este estudo se refere foi realizada na cidade de Brasília, especificamente nas aulas do Acolher 1 (turma referente ao nível iniciante) do curso intitulado Módulo Acolhimento - Português para Refugiados e Imigrantes, que atende, gratuitamente, refugiados e imigrantes que se encontram em condições sociais e econômicas vulneráveis. 
O curso acontece em dois locais da cidade de Brasília, nas instalações do NEPPE, na Universidade de Brasília, no campus Darcy Ribeiro, onde a pesquisa aqui relatada se desenvolveu e, a partir de setembro de 2016, abrimos uma nova turma na região do Varjão, ${ }^{24}$ em uma escola pública: Escola Classe do Varjão.

Esse curso, como já mencionado no capítulo de introdução, é ofertado pelo Núcleo de Ensino e Pesquisa em Português para Estrangeiros (NEPPE) da Universidade de Brasília, em parceria com o Instituto de Migrações e de Direitos Humanos (IMDH), com o Alto Comissariado das Nações Unidas para Refugiados (ACNUR), com o Programa de Pósgraduação em Linguística Aplicada da Universidade de Brasília (PPGLA), com o Transporte Urbano do Distrito Federal - DFTRANS e com o curso de Design/Unb.

Essas parcerias (IMDH, ACNUR E PPGLA) colaboram com a divulgação e, quando necessário, contribuem com as atividades desenvolvidas durante o curso, oferecendo palestras e auxiliando no atendimento dos alunos. O DFTRANS, até o final de 2015, colaborou com a emissão gratuita de passe de transporte público para todos os inscritos no curso. E o curso de Design/Unb tem contribuído com propostas de diagramação para o material didático.

O Módulo Acolhimento está inserido em dois projetos de pesquisa: PROACOLHER: Português para Estrangeiros: língua-cultura e acolhimento em contexto de migrações internacionais e refúgio $(\mathrm{CnPq})$ e Português como Língua de acolhimento: inserção linguístico laboral no $\mathrm{DF}^{25}$, ambos coordenado pela Professora Doutora Lúcia Maria de Assunção Barbosa.

O curso tem sido oferecido desde agosto de 2013, e, normalmente, é ofertado uma vez no semestre, sendo sujeito a modificações, quando necessárias. Vale destacar que o curso, visando atender com mais eficiência as necessidades e demandas apresentadas pelos aprendentes, está em um contínuo processo de modificações e reelaborações, tanto no processo de ensino-aprendizagem e nas suas materialidades quanto na sua própria organização e estrutura.

Normalmente, o curso é oferecido uma vez por semestre, com calendário flexível. Até o final de 2015, o curso possuía uma carga horária de 60h, sendo organizado em três aulas por semana, com duração de 1 h40 por aula. O curso oferece três níveis: Acolher 1 (iniciantes), Acolher 2 (iniciantes, mas já têm algum conhecimento do português) e, a partir de 2016,

\footnotetext{
${ }^{24}$ Varjão é uma região administrativa do Distrito Federal brasileiro.

${ }^{25}$ Esse projeto conta com o financiamento da FAP-DF - Fundação de Apoio à Pesquisa do Distrito Federal para os anos de 2016 e 2017.
} 
abrimos a turma do Acolher 3 (aprendentes que já passaram pelos níveis anteriores ou aqueles que já estudaram o português). ${ }^{26}$

Vale ressaltar que o curso conta com uma equipe de profissionais qualificados (mestrandas e doutoras) no ensino de português para estrangeiros e com voluntários e pesquisadores de graduação que estão desenvolvendo estudos nesse âmbito de ensinoaprendizagem em contex to de imigração.

Alguns recursos, tais como pagamento de professores, espaço físico, serviços de secretária, divulgação em sites e fotocópias de materiais didáticos necessários para as aulas, são fornecidos pelo NEPPE. Neste sentido, faço questão de registrar meu reconhecimento e friso que o NEPPE tem exercido um papel social inquestionável no âmbito de ensino de língua para essa finalidade que aqui apresentamos. Contamos também com o financiamento da Fundação de Apoio à Pesquisa do Distrito Federal - FAP que custeia seis bolsistas de iniciação científica e um técnico para projeto e outras despesas menores.

Como colocado, o Módulo Acolhimento, até o final de 2015, possuía uma carga horária de 60 h. No entanto, a partir de 2016, em consequência de um problema que tivemos com um dos nossos principais e importantes parceiros, o DFTRANS, foi necessário alterar a organização do curso, reduzindo a carga horária do curso para 30h/a, distribuídas em uma aula por semana, com duração de 1h40. As aulas, nessa reorganização, foram ofertadas nas terças-feiras, das $19 \mathrm{~h}$ às $20 \mathrm{~h} 40$.

O DFTRANS é um parceiro essencial para concretização e continuidade do curso, pois ele nos auxilia com a concessão do passe livre gratuito ao nossos aprendentes. Porém, no início de 2016, por motivos de mudança no sistema da empresa do DFTRANS, os nossos estudantes não conseguiram receber o passe livre para poderem frequentar as aulas.

Dessa maneira, tivemos que, ao longo do semestre, reconfigurar a carga horária do curso, pois muitos dos aprendentes não tinham condições financeiras para arcar com as despesas de duas passagens por semana.

Esse episódio refletiu diretamente na reorganização do curso e também na frequência dos aprendentes, tivemos uma evasão enorme dos nossos aprendentes, o que será mais bem

\footnotetext{
${ }^{26}$ Ainda não temos um teste de nivelamento finalizado, ele está em processo de elaboração. O que realizamos é um mapeamento no primeiro dia de aula, por meio de um questionário (Apêndice D - Questionário - Perfil da turma do Acolher 1, p. 197, para saber qual foi o contato desse (a) aprendente com a língua portuguesa e, em seguida, uma dinâmica de apresentação oral para observar e analisar a competência comunicativa no português. Baseando-se nessas informações, fazemos um prévio nivelamento e dividimos em turmas. Essa divisão não é definitiva. Se observarmos que o (a) aprendente está em um nível não adequado, fazemos uma mudança, conforme o consentimento do(a) aprendente, ou em alguns casos, oferecemos plantões de dúvidas para auxiliar esse (a) aprendente para que possa acompanhar a turma.
} 
discorrido na próxima seção. Além disso, não se pode desconsiderar que com a diminuição da carga horária, o ensino-aprendizagem da língua também ficou prejudicado.

Como colocado pela pesquisadora São Bernardo ${ }^{27}$ (2016, p. 87), que acompanha o Módulo Acolhimento desde o seu início, o objetivo do curso é "ajudar as/os participantes a desenvolverem a Competência Comunicativa Intercultural, adquirindo competência linguística e consciência cultural crítica, evocando o pensamento crítico e ação".

Visando buscar atender a essa finalidade, a cada oferta de curso redefinimos objetivos de ensino e (re)elaboramos as materialidades de ensino.

\subsubsection{O grupo pesquisado}

A pesquisa, como já mencionado, foi realizada no curso Módulo Acolhimento Português para Refugiados e Imigrantes, nas dependências do NEPPE, especificamente na turma do Acolher 1, durante o período que compreende 21 de março a 05 de julho de 2016. A turma obteve $38 \mathrm{hs} / \mathrm{a}$, sendo essas distribuídas em $1 \mathrm{~h} 40$ por semana, nas terças-feiras, das $19 \mathrm{~h}$ às $20 \mathrm{~h} 40$.

Os/as estudantes dessa turma são refugiados e imigrantes que estão vivendo no Distrito Federal e em seu entorno. A turma recebeu um total de 45 inscritos, no entanto, em consequência da não concessão do passe livre, como comentado na seção anterior, se esvaziou e contou, ao final, com 16 estudantes que frequentaram assiduamente as aulas.

Nessa seção, apresento o perfil dos aprendentes inscritos na turma do Acolher 1. Esse perfil foi traçado por meio de um questionário aplicado no terceiro dia de aula. O questionário teve por objetivo mapear o público-aprendente, bem como investigar as nacionalidades presentes, a língua materna dos aprendentes, a idade e o sexo, o nível de escolaridade e as profissões que exerciam no país de origem, há quanto tempo estão no Brasil e quais as razões pelas quais vieram, se estão trabalhando no Brasil e quais são os motivos que os levaram a escolher o curso Módulo Acolhimento e quais os objetivos e interesse na aprendizagem e aquisição de português.

A turma era composta por 5 nacionalidades diferentes (Haiti, Gana, Egito, República Democrática do Congo e Zâmbia). Conforme os dados gerados pelos questionários havia

\footnotetext{
${ }^{27}$ Para mais informações detalhadas sobre o Módulo Acolhimento, consultar a tese de doutorado de Mirelle Amaral de São Bernardo, Português como Língua de Acolhimento: um estudo com imigrantes e pessoas em situação de refúgio no Brasil. nisponível em: $<$ https://repositorio.ufscar.br/bitstream/handle/ufscar/8126/TeseMASB.pdf?sequence=1\&isAllowed=y>. Acesso em: 07 fev. 2017.
} 
presentes 4 línguas maternas distintas (Francês, Creole, Inglês e Árabe), no entanto, saliento, de acordo com as minhas observações feitas ao longo das aulas, que havia mais línguas maternas que não foram explicitadas pelos aprendentes nos questionários, vejamos:

\section{Gráfico 1 - Nacionalidades da turma do Acolher 1}

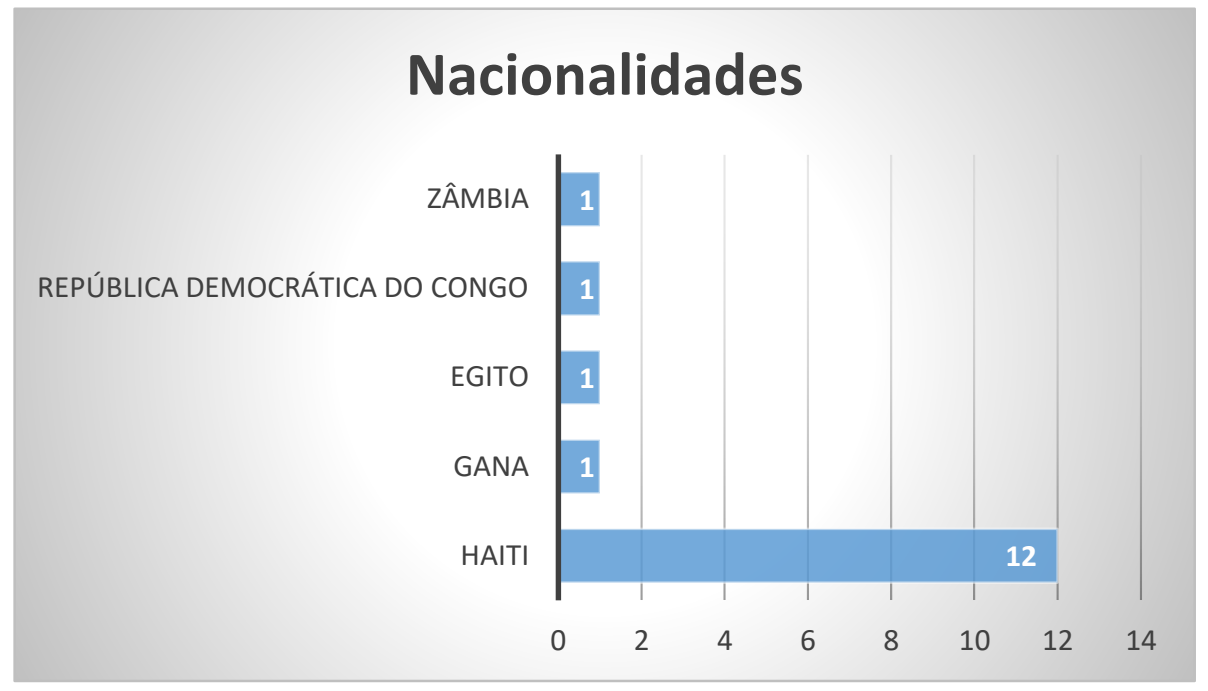

Fonte: Da análise de dados empreendida pela autora.

Do total de 16 estudantes, 14 responderam ao questionário, os outros dois estudantes estavam ausentes. Dessa forma, esse é o perfil traçado dos 14 questionários respondidos. De acordo com os questionários, havia na turma 6 participantes do sexo masculino e 8 participantes do sexo feminino. A idade dos estudantes era de 22 anos a 52 anos. Desse total de participantes, 9 eram solteiros e 5 casados.

O nível de escolaridade entre os aprendentes era de: 8 tinham o ensino médio e 6 o ensino superior. As profissões eram diversas (professor assistente da Universidade do Congo, 2 estudantes de enfermagem, 3 estudantes, recepcionista de hotel, professora de criança, secretária bilíngue, gestora de finanças de uma ONG, professor de francês, músico, técnico em agronomia, socorrista da cruz vermelha e restaurador de ruínas).

Na época, 9 responderam que estavam no Brasil de 1 a 6 meses, 3 recém-chegados e 2 estavam de 7 meses a 1 ano. De acordo com as respostas, 11 dos participantes moravam junto com a família no entorno de Brasília, nas regiões administrativas ${ }^{28}$ e 3 moravam com amigos.

\footnotetext{
${ }^{28}$ O Distrito Federal é composto atualmente por 31 Regiões Administrativas que abrigam cerca de 2,8 milhões de habitantes. As regiões administrativas são subdivisões territoriais do Distrito Federal, cujos limites físicos, estabelecidos pelo poder público, definem a jurisdição da ação governamental para fins de descentralização
} 
As principais razões da vinda para o Brasil consistiram em:

Quadro 3 - Razões da vinda para o Brasil

\begin{tabular}{|c|l|}
\hline Aprendentes & Razões de vinda ao Brasil \\
\hline $\mathbf{2}$ & refúgio \\
\hline $\mathbf{5}$ & para ter uma melhor vida \\
\hline $\mathbf{3}$ & razões profissionais \\
\hline $\mathbf{3}$ & viver com a minha família \\
\hline $\mathbf{1}$ & $\begin{array}{l}\text { conhecer um novo país e uma } \\
\text { nova cultura }\end{array}$ \\
\hline
\end{tabular}

Fonte: Da análise de dados empreendida pela autora.

Conforme os dados do Quadro 3, pode-se perceber que apenas 2 pessoas vieram ao Brasil por questões de refúgio e a maioria por questões mais pessoais, tais como profissional, viver com a família, ter uma vida melhor e conhecer um novo país. As razões podem se divergirem, no entanto, pelas minhas observações durante as aulas, a maioria dos aprendentes dessa turma se encontrava em condições de vulnerabilidade, sobretudo, a econômica, pois até o momento da aplicação do questionário, 11 aprendentes não estavam trabalhando no Brasil, enquanto 3 já haviam conseguido emprego.

Tendo em vista que há outros cursos de português para refugiados e imigrantes sendo oferecidos em Brasília e no seu entorno, inseri nesse questionário uma questão a fim de investigar os motivos que levaram esses estudantes a optarem pelo curso do Módulo Acolhimento, as respostas mostram:

administrativa e coordenação dos serviços públicos de natureza local. Esta ação é exercida por intermédio de cada administração regional. Informações disponível em: <https://pt.wikipedia.org/wiki/Regi\%C3\%A3o_Administrativa_(Distrito_Federal), acesso dia 26/11/2016>. 
Quadro 4 - Motivos para escolherem o curso

\begin{tabular}{|c|l|}
\hline Aprendentes & $\begin{array}{l}\text { Motivos que os/as estudantes escolheram o } \\
\text { curso de língua portuguesa do NEPPE: }\end{array}$ \\
\hline $\mathbf{1}$ & é mais perto de onde moro \\
\hline $\mathbf{3}$ & tem declaração de conclusão \\
\hline $\mathbf{4}$ & é na Universidade \\
\hline $\mathbf{5}$ & tem boa estrutura \\
\hline $\mathbf{4}$ & tem material em português \\
\hline $\mathbf{4}$ & tem mais horas de aula \\
\hline
\end{tabular}

Fonte: Da análise de dados empreendida pela autora.

As motivações apresentadas pelos estudantes deixam evidente que esse públicoaprendente preserva e busca por uma possível qualidade no ensino-aprendizagem do português, pois os itens assinalados se referem mais à estrutura do curso.

E, por último, apresento os objetivos e interesses que cada aprendente expressou ter em aprender e adquirir o português:

Quadro 5 - Objetivo após fazer o curso

\section{Qual é o seu objetivo após fazer este curso?}

Encontrar um emprego e comunicar bem

Uma melhor vida com a família e trabalho

Entrar na Unb ou em outra faculdade para estudar Medicina

Para falar melhor o português e para se sentir a vontade no país

Fazer parte de professional brasileiro

Prolongar os estudos superior e encontrar trabalho apenas para melhorar de vida

Achar um trabalho para atender a minhas necessidades

Trabalhar e aprender outro curso

Trabalhar no Brasil

Encontrar um trabalho para atender as minhas necessidades

Falar bem a língua portuguesa e compreender todo mundo e ir não importa onde sozinha

Continuar o meus estudos superior

Falar bem o português como um brasileiro e trabalhar também para ajudar meus amigos

Fonte: Da análise de dados empreendida pela autora.

Pelas respostas, podemos classificar os objetivos em três aspectos, tais como: 
Gráfico 2 - Classificação dos objetivos

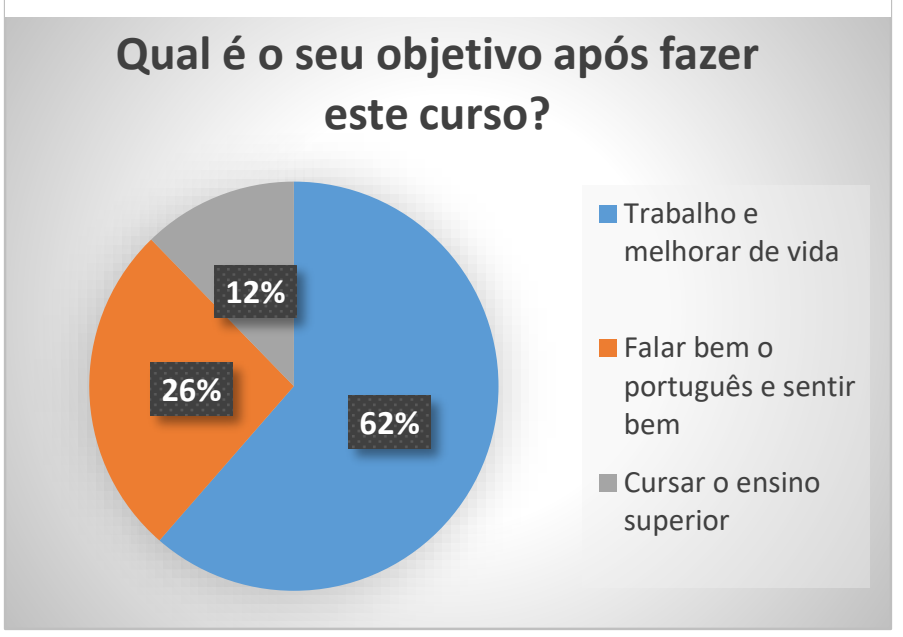

Fonte: Da análise de dados empreendida pela autora.

Esses objetivos vão ao encontro dos apontamentos feitos por Grosso (2010) e Adami (2009), quando afirmam que a motivação e interesses dos aprendentes em adquirirem a língua de acolhimento estão ligados a questões de sobrevivência urgente, para conseguir se movimentar socialmente no novo país e assim suprirem as necessidades básicas, como conseguir um emprego, compreender e ser compreendidos e em busca de melhores condições de vida.

Como se pode observar, essa turma se constitui de um público diverso, heterogêneo, multilíngue, multicultural, multifacetado, com perfis e níveis de escolaridade entre médio e superior, isto é, não tivemos nessa turma nenhum caso de analfabetismo. Esses perfis influenciariam muito no planejamento do ensino.

As motivações e os objetivos não divergem tanto, ao contrário, caminham para o mesmo propósito de terem a língua para poderem inserir-se na sociedade brasileira, seja para trabalhar, para se sentirem bem ou mesmo para continuarem os estudos. Tendo o conhecimento do grupo pesquisado, considero ser também importante, conhecer um pouco da trajetória que tenho trilhado para que possa conhecer e compreender as motivações que me levaram a realizar o presente estudo.

\subsubsection{A professora-pesquisadora}

Sou Pós-graduada em Docência no Ensino Superior pela Faculdade de Educação da Universidade Federal de Uberlândia. Graduada no curso de Letras com licenciatura plena em português/francês e demais literaturas, pela Universidade Federal de Uberlândia. Iniciei minha 
carreira profissional como professora de língua portuguesa em 2011, trabalhando com o ensino fundamental e médio em escolas particulares e públicas na cidade de Uberlândia. No entanto, desde 2009, durante a graduação, participava de projetos de pesquisa sobre o ensinoaprendizagem de português como língua estrangeira. Atuando, durante 1 ano, como participante-estagiária do projeto "Língua Portuguesa e Cultura Brasileira para Estudantes Estrangeiros-Intercâmbio" da Universidade Federal de Uberlândia.

Nesse projeto, realizávamos o acolhimento dos estudantes estrangeiros, oferecendo aulas de língua portuguesa. Foi desde esse momento que comecei a me envolver e me encantar pelo ensino-aprendizagem de português para falantes de outras línguas, no sentindo de acolhê-los no Brasil. Porém, somente em 2014 é que tive a oportunidade de me dedicar exclusivamente a esse tipo de ensino, trabalhando como professora no Núcleo de Ensino e Pesquisa em Português para Estrangeiros (NEPPE) da Universidade de Brasília.

Nesse núcleo, lecionei para os cursos regulares ofertados pelo NEPPE que atendem, em sua maioria, à comunidade estrangeira (estudantes, turistas) e funcionários do corpo diplomático de diferentes países com embaixada em Brasília. E também no curso Módulo Acolhimento - Português para Refugiados e Imigrantes, que atende gratuitamente, desde 2013, refugiados e imigrantes em situação de vulnerabilidade social.

A experiência em trabalhar em dois grupos diferenciados pelo contexto e pelas necessidades foi o que me motivou fortemente a realizar a pesquisa relatada nesta dissertação.

\subsection{Instrumentos de coleta de dados}

A coleta de dados é a fase da pesquisa que consiste em reunir dados de interesse para o desenvolvimento da pesquisa. Bogdan e Biklen (1998) explicam que o termo dados se refere

\footnotetext{
aos materiais brutos que os pesquisadores coletam do mundo que eles estão estudando; eles são as especificidades que formam a base da análise. Dados incluem materiais que as pessoas responsáveis pelo estudo gravam ativamente como as transcrições das entrevistas e as anotações de campo da observação participativa. Dados incluem também o que outros criaram e as descobertas da pesquisa, como diários, fotos, documentos oficiais e artigos de jornal. Os dados são tanto a evidência como as pistas. (BOGDAN E BIKLEN, 1998, p.106).
}

Como descrito pelos autores supracitados, os dados são tanto evidências quanto pistas e é por meio dessas que a pesquisa e a escrita se fundamentam. Por isso, a coleta de dados deve ser feita, de acordo com Bogdan e Biklen (1998), de maneira sistemática e com rigor, pois será 
por meio dos dados que o pesquisador e atores poderão pensar sobre os aspectos da vida que desejam explorar.

Segundo afirmam Marconi e Lakatos (2007, p. 165), a coleta de dados é "uma tarefa cansativa e toma, quase sempre, mais tempo do que se espera. Exige do pesquisador paciência, perseverança e esforço pessoal". Dessa forma, para que a pesquisa e sua escrita sejam salvas de especulações infundadas, é imprescindível cautela, seriedade e ética na coleta de dados.

Dentro do paradigma qualitativo, segundo Abrahão (2006, p. 221) "nenhum instrumento é suficiente por si só, mas a combinação de vários instrumentos se faz necessária para promover a triangulação de dados e perspectivas”. Reforçando essa ideia, Bogdan e Biklen (1998) ponderam que os estudos qualitativos geralmente se utilizam de uma variedade de fontes de dados.

De acordo com Yin (2001) a coleta de dados para os estudos de caso pode se basear em muitas fontes de evidências. $\mathrm{O}$ autor apresenta seis fontes importantes tais como: documentação, registros em arquivos, entrevistas, observação direta, observação participante e artefatos. Entretanto, o mesmo autor ressalta que mais importante do que a seleção dos instrumentos é o pesquisador saber como conduzir a ampla variedade de técnicas utilizadas para a coleta de dados. (YIN, 2001, p 122)

À vista disso, para o desenvolvimento dessa pesquisa utilizei-me dos seguintes instrumentos para a coleta de dados: documentos (material didático reelaborado para esse contexto e nível, textos produzidos pelos aprendentes durante as aulas e fotos captadas durante as atividades interculturais), questionários aplicados ao final das duas atividades realizadas ao decorrer do curso do Módulo Acolhimento e observações -participantes.

A seleção desses instrumentos foi feita, tendo em vista o caso a ser estudado (objetivos e perguntas de pesquisa), o contexto da pesquisa, os recursos financeiros, a disponibilidade da pesquisadora e dos atores envolvidos.

Acredito que a compreensão do que se constitui cada instrumento empregado dentro de uma pesquisa se faz relevante para melhor manuseá-lo.

\subsubsection{Documento}

O instrumento documento foi utilizado com a finalidade de analisar de que forma foram realizados os letramentos de práticas sociais e interculturalidades juntamente com a aquisição da competência linguística de português pelos aprendentes do Acolher 1. Os documentos 
empregados foram dois módulos do material didático, textos produzidos por dois aprendentes durante as aulas e fotos tiradas no decorrer das atividades interculturais.

A concepção de documento assumida neste estudo foi a proposta por Cellard (2012), que alerta que definir documento representa em si um desafio, mas que graças à história social, privilegiando uma abordagem mais globalizante, atualmente pode se ter uma noção mais ampla de documento, sendo esta:

tudo o que é vestígio do passado, tudo o que serve de testemunho, é considerado como documento ou "fonte", como é mais comum dizer, atualmente. Pode tratarse de textos escritos, mas também de documentos de natureza iconográfica e cinematográfica, ou de qualquer outro tipo de testemunho registrado, objetos de cotidiano, elementos folclóricos, etc. (CELLARD, 2012, p 296-297).

Tremblay (1968 apud Cellard 2012, p.295) ressalta que "graças ao documento, pode-se operar um corte longitudinal que favorece a observação do processo de maturação ou de evolução de indivíduos, grupos, conceitos, conhecimentos, comportamentos, mentalidade, práticas, etc". Além disso, Cellard (2012) acentua que o documento escrito constitui uma fonte extremamente preciosa para o pesquisador, pois ele permite realizar a reconstrução de memória e possibilita acrescentar a dimensão do tempo à compreensão do social.

Além disso, Cellard (2012) afirma que, no plano metodológico, a análise documental apresenta algumas vantagens significativas, pois se trata de um método de coleta de dados que elimina, em parte, a eventualidade de qualquer influência do pesquisador sobre o sujeito, pois o documento constitui um instrumento que o pesquisador não domina.

No entanto, a autora ressalta que isso também nem sempre se caracteriza como vantajoso, pois a informação do documento circula em sentindo único, ou seja, "o documento permanece surdo e o pesquisador não pode dele exigir precisões suplementares" (CELLARD, 2012, p.296). Tendo em vista isso, utilizei da observação participante para enriquecer a coleta de dados e análise desses, pois, por meio da observação participativa pude apreender informações, sensações que deram maior sentindo e validade aos dados recolhidos.

\subsubsection{Observação participante}

A observação participante, conforme mencionada acima, foi aplicada a esta pesquisa aqui relatada, para complementar os dados gerados pelos instrumentos de coleta e permitir, com detalhamento, a contextualização das informações gerada pelos dados.

Correia (2009) discorre que a observação participante é 
uma técnica de eleição para o investigador que visa compreender as pessoas e as suas atividades no contexto da ação, podendo reunir na Observação Participante, uma técnica de excelência que lhe permite uma análise indutiva e compreensiva. (CORREIA, 2009, p.31).

A observação participante, em conformidade com Correia, é realizada em contato direto, frequente e prolongado do investigador com os atores sociais, sendo assim o próprio investigador o instrumento de pesquisa. $\mathrm{O}$ autor ressalta que a observação participante é “dinâmica e envolvente" (CORREIA, 2009, p. 31).

Para a realização da pesquisa aqui relatada, utilizei-me da observação participante, pois estive em contato direto e frequente com o caso analisado, isto é, estive em contato com os aprendentes da turma do Acolher 1, uma vez que eu fui a professora da turma. Destaco que as observações participantes contribuíram fortemente para esta pesquisa ter um caráter êmico, pois a relação entre pesquisadora e o grupo analisado tornou-se mais próxima.

Dessa forma, as observações se efetivaram no decorrer das aulas do Acolher 1 e foram conduzidas de uma forma mais livre, não estruturada, sem roteiro prévio, no entanto, com objetivos delimitados, tais como investigar como os aprendentes realizavam e participavam das tarefas propostas, por meio do material didático e dos procedimentos para experienciar a línguaalvo, e como essas tarefas possibilitaram o desenvolvimento de competência linguística, letramentos de práticas sociais e interculturalidade.

Destaco que algumas observações foram registradas em notas de campo de maneira não sistematizada em um caderno da pesquisadora, as quais estão anexas no Apêndice F, página 200, desta dissertação. Foram anotadas algumas situações específicas e reflexões, não houve uma anotação descritiva e detalhada de todas as aulas.

Somente após o contato com todo o material coletado para análise dos dados gerados que a pesquisadora, em um trabalhado árduo, reconstitui as observações, as memórias e percepções tidas durante a pesquisa.

\subsubsection{Notas de campo}

Bogdan \&Biklen (1994) destacam que para ser bem-sucedido um estudo de observação participante é preciso tomar notas de campo detalhadas, precisas e extensivas. Eles afirmam que: 
Nos estudos de observação participante todos os dados são considerados notas de campo; este termo refere-se colectivamente a todos os dados recolhidos durante o estudo, incluindo as notas de campo, transcrições de entrevistas, documentos oficiais, estatísticas oficiais, imagens e outros materiais. Usamos aqui o termo no seu sentido mais estrito. (BOGDAN\&BIKLEN,1994, p. 150).

O conteúdo das notas de campo, segundo os autores supracitados, consiste em dois tipos de materiais: descritivo e reflexivo. O primeiro preocupa-se em captar uma imagem, por palavras do local, pessoas, ações e conversas observadas. O segundo consiste em apreender mais o ponto de vista do observador, as suas ideias e preocupações. (BOGDAN \& BIKLEN,1994, p. 152)

Como mencionado acima, as notas de campo, não foram sistematizadas, nem descritivas, algumas foram registradas durante o desenvolvimento da pesquisa e outras, por meio da reconstituição das observações/memórias, durante a análise dos dados gerados.

\title{
3.3.4 Questionário
}

O instrumento questionário, apesar de ser um instrumento visto por alguns pesquisadores como "frio", porque, às vezes, não permite o conhecimento das circunstâncias em que foi respondido, é um dos procedimentos que tem sido utilizado em pesquisas para obter informações, pois apresenta vantagens tais como as descritas por Dörnyei (2003):

\begin{abstract}
A principal atração dos questionários é a sua eficiência sem precedentes em termos de (a) tempo do investigador, (b) esforço do investigador e (c) recursos financeiros. Ao administrar um questionário a um grupo de pessoas, pode-se coletar uma enorme quantidade de informações em menos hora, e o investimento pessoal necessário será uma fração do que teria sido necessário para, digamos, entrevistar o mesmo número de pessoas. Além disso, se o questionário estiver bem construído, o processamento dos dados também pode ser rápido e relativamente direto, especialmente usando algum software de computador moderno. (DÖRNYEI 2003, p.09, tradução minha) ${ }^{29}$
\end{abstract}

\footnotetext{
29 Trecho original: "The main attraction of questionnaires is their unprecedented efficiency in terms of (a) researcher time, (b) researcher effort, and (c) financial resources. By administering a questionnaire to a group of people, one can collect a huge amount of information in less than an hour, and the personal investment required will be a fraction of what would have been needed for, say, interviewing the same number of people. Furthermore, if the questionnaire is well constructed, processing the data can also be fast and relatively straightforward, especially by using some modern computer software" (DÖRNYEI 2003, p.09)
} 
No contexto da pesquisa aqui relatada, o questionário se tornou um instrumento de coleta de dados apropriado, pois possibilitou atingir um número maior de participantes, foi de baixo custo financeiro e foi acessível em tempo e local a todo(a)s o(a)s participantes, uma vez que os questionários foram aplicados no dia e horário das aulas e das atividades interculturais. Além disso, os questionários puderam ser traduzidos em outras línguas (Francês e Inglês), o que colaborou para uma melhor compreensão das questões propostas aos participantes e uma melhor comunicação e expressão, pois eles puderam responder a questão aberta na língua de origem de seus países.

Dessa maneira, para o desenvolvimento deste estudo, os questionários constituíram-se em um instrumento de pesquisa válido, pois proporcionaram uma coleta de dados eficiente e proveitosa para investigar o perfil dos aprendentes do Acolher 1 e as percepções que esses obtiveram das atividades realizadas no curso.

Para este estudo, utilizei-me de questões mistas, a maior parte do questionário foi elaborada com questões fechadas, no entanto, inseri algumas questões abertas, objetivando dar a possibilidade aos respondentes de se expressarem da forma mais espontânea e real.

Como mencionado, todos os questionários aplicados nesta pesquisa foram disponibilizados em três línguas (português, inglês e francês), visando uma ética no desenvolvimento da presente pesquisa e uma melhor compreensão para os aprendentes sobre o que estava sendo investigado.

\subsection{Procedimentos de coleta de dados}

A análise de dados, de acordo com Yin (2001, p 131) consiste em "examinar, categorizar, classificar em tabelas ou, do contrário, recombinar as evidências tendo em vista proposições iniciais de um estudo".

Bogdan \& Biklen (1998) definem a análise de dados qualitativa como:

\footnotetext{
um processo sistemático de exploração e organização de entrevistas, notas de campo e outros materiais que você acumula para ampliar sua própria compreensão sobre eles e para capacitá-lo(a) a apresentar o que você descobriu para outros. A análise envolve trabalhar com os dados, organizá-los, dividi-los em unidades manejáveis, sistematizá-los, identificar padrões, descobrir o que é importante, o que é para ser aprendido e decidir o que você contará aos outros. (BOGDAN \& BIKLEN, 1998, p.157).
}

Tendo em vista a importância e necessidade de organizar a análise dos dados e conseguir assegurar uma compreensão em profundidade do fenômeno investigado, este estudo, levando 
em conta os dados gerados tais como: textos, fotos, notas de campo e respostas dos questionários, utilizo-me de procedimentos da análise documental para compreender, interpretar e analisar os documentos e da técnica da triangulação como uma alternativa para validar e unir, por meio de categorias, as informações trazidas pelos instrumentos de coleta. Toda a análise foi conduzida a fim de responder ao objetivo e às perguntas da pesquisa.

\subsubsection{Análise documental}

Cellard (2012 p. 296) alerta que o pesquisador que trabalha com documentos deve superar vários obstáculos e desconfiar de inúmeras armadilhas, antes de estar em condição de fazer uma análise em profundidade de seu material.

Ele propõe que primeiro é preciso localizar os textos pertinentes, avaliar a sua credibilidade e representatividade e verificar se o autor do documento conseguiu reportar fielmente os fatos ou apenas exprimiu percepções de uma fração particular. Além disso, o pesquisador deve compreender adequadamente o sentindo da mensagem e contentar-se com o que tiver a mão.

À vista disso, Cellard (2012) discorre que é em razão desses limites que o pesquisador terá de tomar certas precauções que facilitarão a tarefa e conferirá garantia da validade e da solidez de suas explicações. Cellard (2012) apresenta seis etapas para proceder a uma análise documental, ressaltando que a avaliação crítica constituiu a primeira etapa. As etapas propostas pela autora são: contexto, autores, interesses, confiabilidade, natureza do texto e conceitoschave.

Outro fator que deve ser levado em conta para a análise de documento é a lógica interna, o esquema ou o plano de texto. Isto é, deve-se observar os conceitos-chave presentes em um texto, avaliando sua importância e seu sentindo, de acordo com o contexto em que eles são empregados, observar se são desenvolvidas as partes de um texto.

Cellard (2012) destaca esse fator, pois afirma que esse procedimento é útil e necessário para comparar os vários documentos da mesma natureza. Foi à luz desses conhecimentos propostos por Cellard (2012) que os documentos gerados pela coleta de dados foram analisados.

\subsubsection{Categorias}

Ludke \& André (1986, p. 48) ressaltam que a etapa mais importante é a criação de categorias ou categorização dos dados. Eles destacam que "não existem normas fixas nem 
procedimentos padronizados para a criação de categorias, mas acredita-se que um quadro teórico consistente pode auxiliar uma seleção inicial mais segura e relevante".

De acordo com Bogdan \& Biklen (1998) o sistema de codificação envolve vários passos, para eles é preciso:

\begin{abstract}
percorrer os seus dados na procura de regularidades e padrões bem como de tópicos presentes nos dados e, em seguida escreve palavras e frases que representam estes mesmos tópicos e padrões. Estas palavras e frases são categorias de codificação. As categorias constituem um meio de classificar os dados descritivos que recolheu (os símbolos segundo os quais organizaria os brinquedos), de forma a que o material contido num determinado tópico possa ser fisicamente apartado do outros dados. (BOGDAN\& BIKLEN 1998, p.221).
\end{abstract}

Além disso, os autores salientam que algumas das categorias de codificação podem surgir à medida que for recolhendo os dados, dessa maneira, deve-se anotar estas categorias para utilizá-las mais tarde.

Dessa forma, a análise de dados dessa pesquisa foi conduzida partindo, a priori, de uma estratégia analítica geral, em que tomei conhecimento dos dados gerados pelos diversos instrumentos, em seguida, revisitei as perguntas de pesquisa.

A primeira pergunta constitui-se em apresentar os objetivos de ensino para a turma do Acolher 1, objetivos baseados em aportes teóricos e na minha experiência docente. A segunda pergunta fundamentou-se em analisar o material didático, módulos Apresentação e Trabalho, os procedimentos para experienciar a língua, atividades nomeadas interculturais, Chá\&Prosa e Despertar Profissional e, de acordo com os dados gerados por esses, estabeleci matrizes de categorias, o que consistiu em organizar e categorizar, por meio da triangulação dos instrumentos de coleta, as evidências encontradas nos dados gerados que respondessem à pergunta de pesquisa.

\title{
3.5 Considerações éticas
}

Considerando a importância de conduzir uma pesquisa sob princípios éticos e verossímeis, é importante aqui registrar que, nesta pesquisa, preocupei-me em informar a todos os participantes, no caso, a turma do Acolher 1, os participantes das atividades interculturais, sobre a existência da pesquisa, bem como sobre os processos e ações que seriam desenvolvidos ao longo das aulas e das atividades.

Para assegurar-me de que estavam de acordo com a participação na pesquisa e com o fato de concederem dados para ela, tais como os textos dos aprendentes, as fotos registradas e as 
respostas dos questionários, solicitei que lessem o Termo de Consentimento e, se estivessem de acordo com as condições apresentadas no documento, que o assinassem. Para garantir a compreensão por parte de todos os participantes, os termos foram disponibilizados em três línguas: português, inglês e francês. O modelo dos termos estão no APÊNDICE C - Termos de consentimentos, página 195, desta dissertação.

Dessa forma, somente foram utilizados para esse trabalho os documentos que foram autorizados pelos participantes, por meio da assinatura dos termos.

Além disso, ressalto que essa pesquisa contou com preciosas reflexões e apontamentos de amigos e profissionais no âmbito de ensino de língua. Durante a escrita, recorri a esses profissionais que solidariamente ouviram minhas dúvidas, angústias e orientaram-me para caminhos e leituras que contribuíram imensamente para a construção desta dissertação.

Dado a conhecer o caminho metodológico que a pesquisa aqui relatada percorreu, assim como o contexto e o perfil do grupo analisado, nos próximos capítulos, passo para a análise dos dados gerados durante a pesquisa e, em seguida, para as considerações finais. 


\section{CAPÍTULO IV: ANÁLISE DOS DADOS}

Neste capítulo, tendo em vista a finalidade do estudo, proponho responder às perguntas de pesquisa e que vale a pena serem retomadas aqui:

1. Quais são os objetivos do ensino-aprendizagem de português para a turma do Acolher 1 no Módulo Acolhimento?

2. Como o material didático e os procedimentos para experienciar a língua buscaram atender aos objetivos propostos?

O capítulo está organizado conforme a sequência exposta das perguntas de pesquisa: $1^{\text {a }}$ Definição dos objetivos do ensino-aprendizagem de português para a turma do Acolher 1; $2^{\mathrm{a}}$ Análise das materialidades de ensino. As materialidades destacadas neste estudo foram o material didático e os procedimentos para experienciar a língua. O material didático consistiu em dois módulos Apresentação e Trabalho e os procedimentos para experienciar o português resultaram em duas atividades nomeadas interculturais, sendo elas ChádProsa e Despertar Profissional.

Para responder à primeira pergunta, utilizei-me de aportes teóricos e da minha experiência docente de português como língua de acolhimento.

Para responder à segunda pergunta, recorri aos instrumentos de coleta de dados, módulos Apresentação e Trabalho, aos textos produzidos pelos aprendentes, às minhas observações participantes, às notas de campos, aos registros de fotos e aos questionários aplicados nas duas atividades interculturais. Para analisar os dados gerados por esses instrumentos, estabeleci categorias de acordo com os objetivos propostos na primeira pergunta e identifiquei nos dados as evidências relacionadas às categorias.

Destaco que antes das análises das materialidades, apresento uma seção fazendo descrição dessas. Essa descrição torna-se necessária para melhor compreender como as materialidades têm sido construídas no Módulo Acolhimento.

Considero relevante salientar que as análises foram realizadas por meio de uma narrativa descritiva e analítica e menos formal, indo ao encontro do que é proposto por Freebody (2003) quando sugere que o relato de um estudo de caso seja mais fluido.

Essa opção de narrativa me possibilitou expor, compartilhar e analisar as minhas percepções mais pungentes de maneira mais livre e fluida. No entanto, não deixarei de interligar de modo direto ou indireto, na medida do possível, as análises com as teorias apresentadas, até 
porque acredito que ter o conhecimento da teoria contribui para corroborar as minhas percepções e para compreender a dimensão do que tem sido realizado, discutido e pesquisado.

\subsection{Objetivos proposto para o ensino-aprendizagem de português como língua de acolhimento para turma do Acolher 1 - no Módulo Acolhimento}

Tendo em vista a concepção de língua de acolhimento, o contexto de ensinoaprendizagem, as especificidades desse ensino e os objetivos e motivações dos aprendentes precisarem da língua para conseguirem se movimentar socialmente no novo país e assim suprirem as necessidades básicas, como conseguir um emprego, alugar uma casa, ir ao médico, entre outras ações imprescindíveis à sobrevivência -, defini objetivos de ensino-aprendizagem de português para turma de nível iniciante, Acolher 1, do curso Módulo Acolhimento.

Segundo Almeida Filho (2011, p. 53) há dois tipos de ensino, o ensino da língua para aprendizagem e o ensino da língua para aquisição. Essa distinção entre aprendizagem e aquisição foi feita a partir dos estudos de Krashen nos anos 1980. Contudo, ainda hoje há teóricos e pesquisadores que preferem utilizar o termo aprendizagem de modo abrangente. Nesta pesquisa, faço a distinção entre aprendizagem e aquisição, pois considero processos distintos que demandam métodos e procedimentos diversos que influenciam na elaboração das materialidades de ensino.

O ensino da língua para a aprendizagem, de acordo com Almeida Filho (2011) se orienta para um ensino de forma mais sistêmica, direcionado ao conhecimento da estrutura e do funcionamento das regras da língua-alvo. Nesse ensino, o enunciado tem origem na língua materna, podendo conscientemente passar para a segunda língua (LEFFA, 1998).

Almeida Filho (2011) ressalta que o ensino para a aprendizagem é guiado por uma abordagem mais gramatical e requer do estudante um aprender mais consciente e atento. $\mathrm{O}$ ensino para aquisição, segundo Almeida Filho, visa a uma prática que objetiva mais a desenvolver a competência de uso da língua-alvo; a estrutura e o funcionamento são ensinados à medida que os aprendizes sinalizam a necessidade.

Leffa (1988), embora considere um refinamento a distinção entre aprendizagem e aquisição, conceitua aquisição como o "desenvolvimento informal e espontâneo da segunda língua, obtido normalmente através de situações reais, sem esforço consciente" (LEFFA, 1988, p. 03). Na aquisição, conforme Leffa (1998), o enunciado se origina diretamente na segunda língua. A abordagem que normalmente norteia esse ensino é a abordagem comunicativa e 
segundo Almeida Filho (2011) esse ensino demanda do aprendente uma abertura afetiva e emocional favoráveis, assim como motivações positivas.

Vale ressaltar que tanto a aprendizagem quanto a aquisição podem ocorrer em uma sala de aula, no entanto, é muito comum pesquisadores e teóricos associarem a aprendizagem com o ensino formal enquanto a aquisição com o ensino informal. Se pensarmos no contexto de ensino de português como língua de acolhimento, o ideal seria ensinar a língua para aquisição, uma vez que esses aprendentes estão imersos no país da língua-alvo e precisam saber 'usar' a língua, porém, não se pode desconsiderar que muitos dos aprendentes, devido à sua cultura de aprender, necessitam e desejam, sobretudo no primeiro contato com a língua-alvo, saber 'sobre' a língua e seu funcionamento.

Dessa maneira, no Módulo Acolhimento tenho buscado desenvolver um ensino de português pelo viés da aquisição e norteado por uma abordagem comunicativa, no entanto, quando necessário e solicitado pelos aprendentes, não hesito em utilizar um ensino de forma mais sistêmica para explicar pontos gramaticais ou mesmo a estrutura e funcionamento da língua.

Outro ponto que destaco sobre a vantagem de tentar propor um ensino para aquisição é que esse, conforme Almeida Filho $(2011,58)$, colabora para “desestrangeirizar” a língua dita estrangeira, isto é, "fazer com que essa língua deixe de ser alheia e possa dar sinais de converterse numa língua que passa a ser do aprendente também".

No contexto do ensino de língua de acolhimento esse "desestrangeirizar" é fundamental para concretizar e desenvolver um dos propósitos da língua de acolhimento em "acolher, alojar, asilar, acomodar e recolher” (BARBOSA e SÃO BERNARDO, 2017, no prelo).

O ensino para aquisição, como colocado, objetiva promover um ensino voltado para o saber usar a língua e assim desenvolver a competência de uso dessa língua. Essa finalidade é de extrema importância para o contexto de ensino de língua de acolhimento, no entanto, tenho percebido durante os cursos ofertados no Módulo Acolhimento que esse saber usar a língua implica-se outros fatores, tais como o conhecimento das culturas da língua, das práticas socioculturais utilizadas nessas culturas e do contato mais próximo com os nativos da línguaalvo, no caso, os brasileiros.

Quando menciono culturas no plural, reconheço que há, em uma língua, inúmeras culturas, embora muitas vezes, por representações construídas, cairmos no clichê e ledo engano de associar uma língua com apenas uma cultura.

Essas observações feitas durante a minha prática docente influenciaram-me a reelaborar os objetivos e as materialidades de ensino para a turma do Acolher 1 no Módulo Acolhimento. 
Notei que alguns aprendentes apresentavam dificuldades na aprendizagem e na aquisição do português, porque, muitas vezes, não tinham nenhum conhecimento das culturas presentes na sociedade brasileira e também porque não tinham contato mais próximo com brasileiros para que pudessem criar redes de amizade e vivenciar trocas culturais.

Além disso, observei que muitos dos aprendentes, principalmente os de níveis de escolaridades mais baixas, não conseguiam responder a demandas ligadas às práticas sociais utilizadas na sociedade brasileira, tais como elaborar um currículum, encontrar e compreender anúncios de emprego, enviar um e-mail, dentre outras práticas sociais.

Levando essas observações em consideração, sugiro que o ensino-aprendizagem da língua de acolhimento busque proporcionar um ensino linguístico-cultural entrelaçado com práticas de letramentos e interculturalidades, para que assim, os aprendentes consigam adquirir a língua-alvo para poderem agir e se movimentar linguisticamente, culturalmente e socialmente nas diversas situações cotidianas da nova sociedade, de maneira que sejam capazes de realizar coisas que os ajudem a suprir as necessidade básicas e a promover a acolhida e inserção desse público na sociedade de acolhida.

Tendo isso em vista, reconheço que a dificuldade encontrada, muitas vezes, é saber como propor, elaborar, conduzir esse tipo de ensino, de maneira que aborde a cultura da língua, letramentos, interculturalidades e acolhimento.

De acordo com a perspectiva de Zanatta (2009), ensinar a cultura da língua a ser estudada não é apenas fazer uma apresentação didática e, às vezes, estereotipada, mas possibilitar uma interculturalidade, ou seja, possibilitar que o aprendente possa refletir e, por vezes, em um processo comparativo conhecer a nova cultura que se apresenta e até mesmo a própria cultura.

Entretanto, Zanatta (2009) destaca que é preciso se atentar aos tipos de atividades comparativas, pois essas, muitas vezes, contribuem para reforçar estereótipos. Segundo a autora, para promover a interculturalidade é fundamental elaborar ou utilizar atividades/processos que extrapolem comparações e promovam efetivamente uma reflexão que atravesse o limite da própria cultura, pois se as atividades/processos ficarem somente direcionados a comparações, esse(a)s, além de não contribuírem em nada com o aprendizado e aquisição da língua, poderão apenas colocar-se como ilustrações de curiosidades culturais, levando, por vezes, a julgamentos e reforçando estereótipos.

Dessa forma, é importante ter o cuidado para que a abordagem cultural não fique apenas em sanar curiosidades, mas que seja conduzida de maneira a permitir um entendimento das 
práticas sociais da cultura da língua-alvo e também da própria cultura do aprendente, despertando nele um senso crítico. Mendes (2010) ressalta que

o conteúdo cultural é veiculado e relativo a um conjunto estanque de informações sobre as peculiaridades do cotidiano e estereótipos do grupo em questão, sem considerar os esquemas disponíveis na própria cultura dos alunos. (MENDES, 2010, p.57).

Essa afirmação nos alerta e nos instrui para não somente apresentar, impor ou despejar conteúdos culturais nas aulas de língua, mas possibilitar a extensão do conteúdo cultural de forma a permitir o acesso aos esquemas disponíveis na cultura dos alunos para que realmente esse ensino se faça significativo, real e intercultural.

Quando Mendes (2010, p.57) se refere a acessar os esquemas disponíveis na cultura dos alunos, considero que o professor de língua não pode se esquecer ou ignorar a bagagem cultural e pessoal que o aprendente traz para a sala de aula, ao contrário, é preciso valorizar e instigar nos aprendentes reflexões de como essa bagagem e história de vida podem ajudá-los a compreender, a respeitar e a interagir com a cultura e a comunidade da língua-alvo.

Se o professor não levar em conta essa bagagem do estudante, o processo de aprendizagem da língua estrangeira pode se tornar, conforme Zanatta (2009, p.159) diz "muito humilhante e, também, entediante, e por esta razão os alunos perdem o interesse pela língua e resistem a participar da aula, comprometendo assim sua capacidade linguístico-discursiva”.

Por isso, é importante entender e refletir sobre como abordar a questão da cultura nas aulas de LE/L2 e sobre como essa abordagem pode propiciar uma interculturalidade e assim um processo menos entediante da aprendizagem e aquisição da língua-alvo. Para Zanatta, a interculturalidade:

auxilia seus alunos a perceber as diferenças étnicas e culturais que permeiam as diferentes culturas, promovendo, desta forma, maior respeito e revitalização entre as culturas, tornando, assim, o aprendizado da língua mais motivador e eficaz. (ZANATTA 2009, p. 159-160).

No contexto de língua de acolhimento em que, normalmente, temos em sala de aula um público-aprendente diverso, heterogêneo, multilíngue, multicultural, multifacetado, com diferentes perfis e níveis de escolaridade, o ensino intercultural se torna imprescindível, tanto para o processo de ensino da língua, quanto para gerir as relações dentro da sala de aula e também fora desta, nas extensões sociais do dia a dia com a comunidade da língua-alvo. 
Se conduzirmos um ensino que produza trocas culturais, todos os sujeitos envolvidos têm a ganhar com esse intercâmbio, os aprendentes em sala de aula e a sociedade que os acolhe, pois para desenvolver a interculturalidade é necessário, conforme afirma Kramsch (2009), exercer continuamente a alteridade.

Esse processo de se colocar no lugar do outro ou mesmo no reconhecimento do outro, seja como igual ou diferente culturalmente, se caracteriza como um processo enriquecedor, pois possibilita o compartilhamento de trocas e experiências culturais e pessoais, novos conhecimentos, novas formas de pensar, de agir, de sentir.

Diante disso, a importância de promover a interculturalidade no ensino-aprendizagem da língua de acolhimento pode ser profícuo em vários aspectos, tanto para propiciar um ensino da língua mais significativo e respeitoso quanto para nutrir a construção de uma sociedade mais democrática e mais respeitosa para com as diversidades.

Em relação ao ensino da língua estar entrelaçado com práticas de letramentos, pondero que essas podem colaborar para promover a inserção social desses indivíduos, uma vez que o letramento à que me refiro está ligado à prática social da língua escrita, o que incluiu os processos sociais da leitura e da escrita (MAGALHÃES, 2012, p. 19).

De acordo com Rios (2010) quando se fala em 'letramento', é preciso antes de tudo distinguir dois sentidos fundamentais que o termo apresenta: o letramento como um campo de estudos e o letramento como um processo ocorrente na vida social.

Conforme Rios (2010), o primeiro está relacionado ao letramento como um tipo de área de conhecimento que vem para redesenhar o quadro tradicional de disciplinas científicas, tendo o entendimento que letramento está vinculado a um tempo de escolarização e o que deve ser estudado é o que o indivíduo sabe fazer de leitura e escrita em decorrência desse tempo que passou na escola.

O segundo sentido, o letramento compreende tudo que um indivíduo tenha feito de leitura e escrita em sua vida, dentro ou fora da escola, isto é, segundo Rios (2010) o letramento:

\footnotetext{
tem início na vida de um indivíduo desde que esteja exposto a textos - sejam estes painéis de rua, placas sinalizadoras ou de propaganda, avisos, gráficos, livros, artigos, formulários, orçamentos, contratos de financiamento... - ou a falas que tendem a reproduzir a linguagem de textos e que são posteriormente reconhecidas quando o indivíduo lê esses textos. (RIOS, 2010, p.78).
}

Pode-se perceber que o segundo sentido apresenta uma visão sobre letramento sob uma perspectiva mais ampla e aplicada a todas as esferas da vida social. Rios (2010) esclarece que muito da confusão que se tem entre 'letramento' e 'alfabetização' é consequência da falta de 
distinção dos sentidos do letramento e, também, de acordo com Mortatti (2004), essa confusão aconteceu e ainda acontece, especificamente no Brasil, em decorrência do próprio surgimento e tradução da palavra letramento. Segundo a autora, o termo surgiu, sob influência do inglês literacy que até a década de 1990, era traduzido por "alfabetização", e, logo em seguida, por "alfabetismo". Como ainda os estudos dessa época, acerca do letramento, estavam incipientes, por um tempo a palavra "letramento" ficou diretamente relacionada a palavra "alfabetismo".

Neste trabalho uma das definições de que me aproprio é a proposta por Rios (2010, p.173) que diz que "letramentos são compreendidos como atos socioculturais concretos que são constituídos por no mínimo umas das seguintes atividades - escrita, leitura e conversa relacionada ao texto escrito".

Tendo em vista a finalidade do ensino proposto na língua de acolhimento, as práticas de letramentos são imprescindíveis a esse contexto, pois podem contribuir para o aprendente adquirir e saber usar a língua-alvo para efetivamente movimentar-se e agir em meios sociais, tais como para ler um anúncio de emprego, um folheto de mercado, para escrever um curriculum, um e-mail, uma carta de motivação ou mesmo um bilhete, para falar diante de uma apresentação pessoal ou numa entrevista de emprego.

Irei me referir a "letramentos" no plural, pois conforme Street $(2012$, p. 82) "não há um letramento autônomo, monolítico, único, cujas consequências para indivíduos e sociedades possam ser inferidas como resultados de suas características intrínsecas”, ao invés disso, há 'letramentos', ou como nos traz Street, há 'práticas de letramento' as quais se referem as atividades, as práticas, as ações e aos processos sociais que envolvem a escrita e a leitura, contextualizadas e utilizadas na sociedade. Dessa maneira, conforme afirma Magalhães (2012, p. 165) "conhecer letramentos é, de certa forma, entender as práticas de uma sociedade e de uma cultura particular".

Nesse sentido o atrelamento de ensino de línguas com práticas de letramento pode colaborar para tornar o ensino mais significativo e motivador, uma vez que o letramento, segundo Grillo (1989 apud Street, 2014, p.19) também pode ser visto "como um tipo de prática comunicativa". E, além disso, o contato com as práticas de letramentos atendem ao objetivo de tornar os aprendentes mais autônomos para movimentar-se na língua-alvo e lidar bem com práticas socioculturais presentes cotidianamente na sociedade brasileira.

E, por fim, o objetivo do ensino-aprendizagem de português como língua de acolhimento no Módulo Acolhimento é conduzir todo esse processo de ensino-aprendizagem entrelaçado com práticas de letramento e interculturalidades, de maneira acolhedora e sensível, 
para perceber e compreender as tensões e conflitos que pode haver nesse contexto de ensino de língua de acolhimento.

A fim de resumir os objetivos propostos para conduzir o ensino-aprendizagem de português para turma do Acolher 1, apresento o quadro a seguir:

Figura 4 - Objetivos do ensino-aprendizagem para a turma do Acolher 1

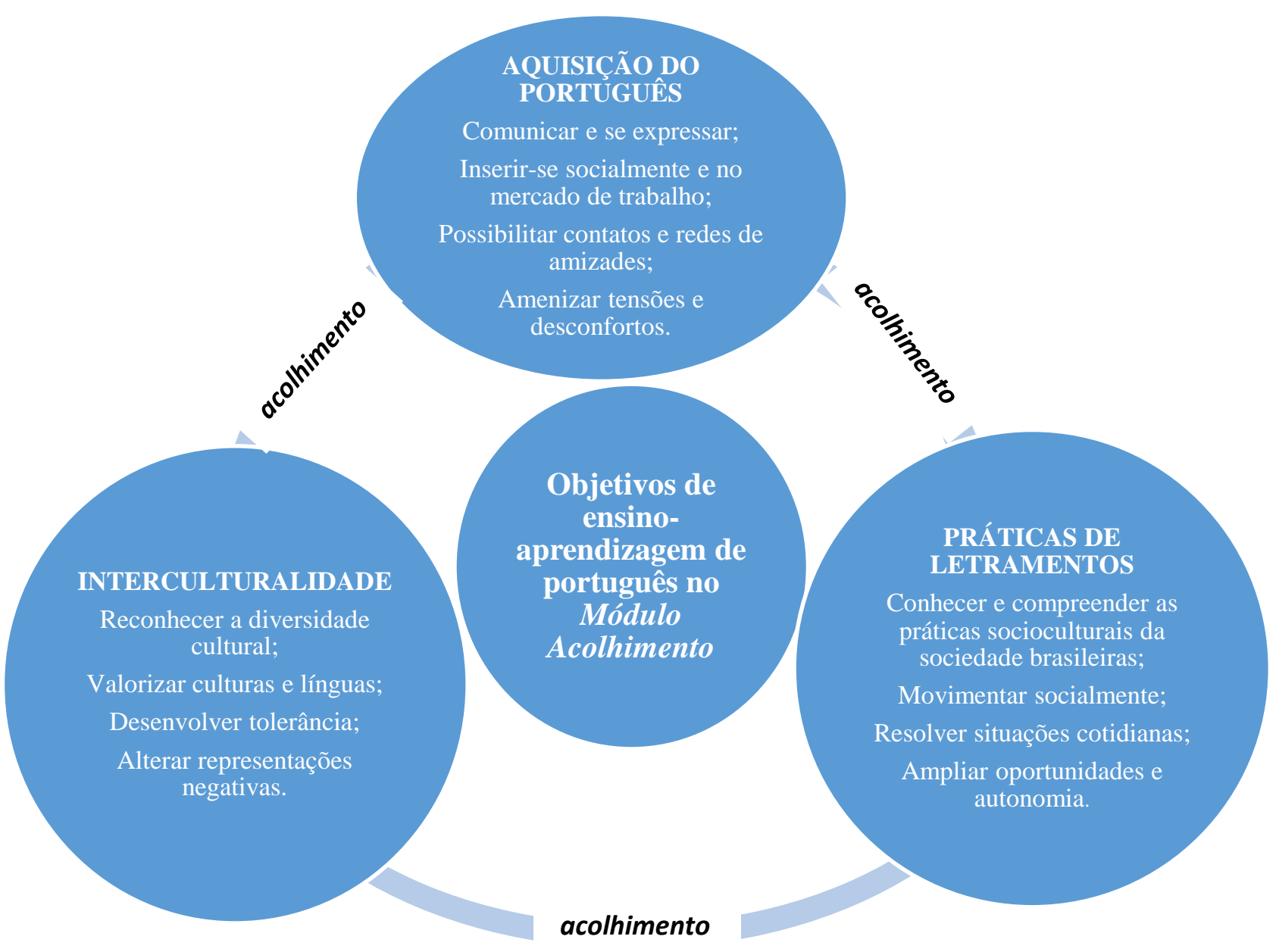

Fonte: Elaborado pela autora

Dessa forma, tendo em vista esses objetivos é que as materialidades de ensino foram reelaboradas e aplicadas na turma do Acolher 1 .

Como mencionado, de acordo com os objetivos, estabeleci categorias para analisar o material didático e as atividades interculturais, as categorias se dividem em quatro: $1^{a}$ aprendizagem e aquisição de português; $2^{a}$ Reconhecendo letramentos; $3^{a}$ Efeitos interculturais e $4^{a}$ Sentimento de acolhimento. 


\subsection{Análise das materialidades do Acolher 1}

\subsubsection{Descrição do material didático do Módulo Acolhimento}

Pelas pesquisas que realizei pela internet e pelo contato que tive, por meio do Encontro Nacional das Redes de Proteção para Migrantes e Refugiados ${ }^{30}$, com algumas instituições que oferecem o ensino de português a refugiados e imigrantes no Brasil, a questão do material didático para utilizar como recurso durante as aulas ainda se apresenta como um entrave, pois os materiais existentes não atendem ao contexto e aos objetivos de ensino da língua para acolhimento.

Os materiais didáticos de PLE, normalmente, são elaborados de maneira que atendam a um ensino generalizado de língua, dessa forma, não levam em conta as especificidades que cada contexto de ensino apresenta, não atendendo às demandas e aos objetivos do ensino da língua em contexto migratório.

Tendo em vista esse cenário, a equipe do Módulo Acolhimento professore(a)s e pesquisadore(a)s têm se engajado, desde 2014, na árdua tarefa de elaborar e reelaborar um material didático que melhor atenda ao conceito de língua de acolhimento, ao contexto de ensino, ao público-aprendente e aos focos de interesses e motivações que envolvem esse ensinoaprendizagem de português como língua de acolhimento. Destaco que toda oferta de curso, o material didático tem passado por modificações e reelaborações.

Considerando os processos da OGEL apresentados na fundamentação teórica, a elaboração ou seleção de um material didático deve ser norteada conforme a abordagem selecionada e com os objetivos propostos no ensino.

Haja vista a finalidade do ensino-aprendizagem da língua de acolhimento, considero que a abordagem comunicativa se apresenta como a mais adequada para conduzir esse ensino e construir as materialidades, pois ela permite e privilegia o ensino para aquisição, o desenvolvimento da competência comunicativa e o ensino significativo para atender aos objetivos e necessidades do(a)s aprendentes.

Dessa maneira, no Módulo Acolhimento, a elaboração do material didático, assim como os procedimentos para experienciar a língua-alvo têm sido norteados por uma abordagem

\footnotetext{
${ }^{30}$ Esse encontro tem sido realizado anualmente em Brasília, DF. O Encontro Nacional das Redes de Proteção tem por finalidade discutir as práticas positivas das formas de atuar, trocar experiências, dialogar e, também, aprofundar a temática da migração e do refúgio, buscando o estreitamento do trabalho em rede em prol dos migrantes e refugiados.
} 
comunicativa, no entanto, reconheço que ainda estamos em um processo de transição de tensões de abordagens (ALMEIDA FILHO, 2013), o que me leva a considerar que estamos sendo norteados por uma abordagem pré-comunicativa.

Destaco que não irei classificá-la como Abordagem Gramatical Comunicativizada (AGC), como proposta por Santos \& Almeida Filho (2011), pois essa abordagem, segundo os autores mencionados, colocam o conhecimento das regras gramaticais e sua prática em primeiro plano, não sendo esse o objetivo do nosso ensino.

A primeira elaboração do MD foi guiada a princípio pelas intuições e experiências que as professoras obtinham durante as aulas. O MD era produzido à medida em que as aulas aconteciam e de acordo com as demandas observadas em sala de aula. Dessa maneira, a elaboração do MD tem se constituído por um processo colaborativo entre professoras e aprendentes.

Após essa primeira elaboração, com orientações da coordenadora do curso, Prof ${ }^{a}$. Lúcia Maria de Assunção Barbosa, e com leitura e pesquisas realizadas a respeito do ensinoaprendizagem da língua de acolhimento, traçamos e organizamos objetivos mais concretos para produzir um MD que buscasse atender efetivamente às necessidades específicas que envolvem esse ensino-aprendizagem, tais como as circunstâncias, o contexto, o público-aprendente e os focos de interesses e motivações desse público.

Embasadas por teorias e pelas experiências e intuições docentes, começamos a elaborar módulos temáticos. Essa ideia de estruturarmos o MD por temas foi proposta pela coordenadora do curso e pela pesquisadora Mirelle Amaral de São Bernardo que discorrem que "a exploração de temas que sejam próximos à realidade em que vivem ou viveram os alunos pode facilitar a aquisição de uma língua estrangeira" (BARBOSA E SÃO BERNARDO,2014, p 271).

A escolha dos temas para os módulos foi realizada, baseando-se nos estudos apresentados por Adami (2009) sobre a formação linguística dos imigrantes. De acordo com esse autor, o ensino-aprendizagem de língua em contex to de imigração deve contemplar quatro vias sociolinguageiras. Essas vias se dividem em: via profissional, via transacional, via interpessoal e via mediática. Tendo em vista essas vias, o MD foi desenvolvido em seis temas: apresentação, trabalho, moradia, saúde, cotidiano e diversidade brasileira.

Baseando-se nos temas propostos, selecionamos conteúdos, textos, imagens, exercícios, atividades, dinâmicas que acreditamos serem úteis para desenvolver o processo de aquisição e aprendizagem da língua-cultura, priorizando o ensino com foco comunicativo e intercultural.

Além de o MD ser temático, após 2015, ele se tornou modular. Isto é, cada turma tem o direito e a liberdade de escolher quais, dentre os módulos do material didático, querem estudar 
durante o curso. Dessa maneira, salvo o primeiro módulo referente ao tema Apresentação que é fixo para todas as turmas do Acolher 1, os demais são escolhidos pela turma.

Essa escolha do módulo é realizada por meio de uma votação feita antes de terminar o módulo Apresentação, por meio de uma questão escrita. Solicitamos aos aprendentes para que marquem qual o tema que gostariam de estudar nas próximas aulas. Para que não haja dificuldades na compreensão da questão, ela é elaborada em três línguas (português, inglês e francês).

Essa autonomia da escolha da sequência dos módulos, além de possibilitar um ensino mais democrático, uma vez que os aprendentes têm o direito de eleger a escolha, também colabora para termos uma pré-noção sobre a necessidade e interesse de cada turma frente à aprendizagem e aquisição do português.

Os três últimos cursos do Acolher 1 que eu estive conduzindo, incluindo a turma objeto de análise deste estudo, selecionaram o módulo Trabalho. Essa escolha confirma o que Grosso (2010) nos aponta sobre as necessidades e as motivações de aprendizagem e de aquisição da língua de acolhimento estarem ligadas a questões de sobrevivência urgente para se conseguir movimentar socialmente no novo país, como para conseguir um emprego.

Essa responsabilidade ofertada aos aprendentes, de escolher o tema que será estudado, foi pensada tanto para atender as necessidades dos aprendentes quanto para tornar o ensinoaprendizagem da língua mais motivador e significativo. Além disso, a turma, ao ter o poder de escolha do conteúdo que deseja e necessita aprender, torna-se protagonista de sua própria aprendizagem.

Em relação ao tempo para a aplicação de cada módulo, esse não é determinado, haja vista que cada turma leva um tempo diferente. No Módulo Acolhimento, os módulos e o ensino são avançados de acordo com o ritmo da turma e das demandas e solicitações que os aprendentes demonstram. Por exemplo, muitas vezes, por solicitação dos aprendentes, é necessário acrescentar e criar em sala de aula, ou mesmo como tarefa de casa, outros tipos de exercícios, de atividades para melhorar a compreensão de determinados conteúdos.

Essas solicitações, embora prolonguem o tempo em cada módulo, colaboram com as aulas, pois resultam em bons insumos que enriquecem o ensino e contribuem para reformularmos os conteúdos do MD.

Além disso, as demandas demonstram que os aprendentes estão interessados nos conteúdos e assim na aprendizagem e aquisição da língua-alvo. Portanto, o objetivo do nosso ensino não é apresentar módulos mecanizadamente, mas propiciar aos aprendentes um ensino- 
aprendizagem significativo e eficaz da língua-alvo, que respeite o ritmo, a diversidade, a heterogeneidade e as diferentes culturas de aprender que normalmente temos nas nossas aulas.

Diante da descrição geral feita de como o material didático tem sido construído e aplicado, prossigo para a análise dos módulos desenvolvidos na turma do Acolher 1 de 1\%2016.

\subsubsection{Análise dos módulos Apresentação e Trabalho}

O módulo Apresentação, como já explicado, é o primeiro a ser visto por todas as turmas, após esse, outros são estudados conforme a escolha dos aprendentes. Nesta turma, o módulo Trabalho foi selecionado por $80 \%$ dos aprendentes. Em consequência da carga horária ter sido reduzida, somente foi possível desenvolver dois módulos.

A reelaboração desses módulos buscou atender aos objetivos propostos na seção 4.1 deste capítulo, de promover aprendizagem e aquisição da língua-alvo, letramentos de práticas sociais, interculturalidades e acolhimento. Com a finalidade de efetivar esses objetivos, realizei modificações e ampliações nos módulos.

Essas mudanças consistiram em reorganizar a sequência de alguns conteúdos a fim de estabelecer mais coerência entre eles, elaborar mais exercícios e atividades que se direcionavam a desenvolver a competência comunicativa, intercultural e práticas de letramentos sobre o uso da língua.

Nos módulos, com o intuito de desenvolver aprendizagens e aquisição da língua, elaborei exercícios estruturais, nocionais, funcionais, atividades pré-comunicativas, tendo geralmente como ponto de partida insumos provenientes de curtos textos relacionados com situações cotidianas. Os exercícios estruturais, nocionais e funcionais estão presentes nos dois módulos, como podemos ver em alguns exemplos: 
Figura 5 - Exercícios estruturais - Módulo Apresentação

\begin{tabular}{|c|c|c|}
\hline Pratique: & & EXERCíIOS \\
\hline Complete com NO, NA, EM: & \multirow{8}{*}{$\begin{array}{l}\text { PREPOSIÇ̄0 } \\
\text { Em } \\
\text { Em+a }=\text { na } \\
\text { Em+0 }=\text { no }\end{array}$} & 1. Complete com os verbos no Gerúndio: \\
\hline 1. Eu traballho ___ Universidade de Brasilia. & & $\begin{array}{l}\text { a) Ele___ (trabalhar) em um restaurante italiano à noite. } \\
\text { b) Ela ___ (procurar) uma casa para alugar. }\end{array}$ \\
\hline 2.Vocés trabalham ___ em um restaurante. & & c) Nós ___ (precisar) de uma informação. \\
\hline 3. Eles trabalham ___ Shopping. & & $\begin{array}{l}\text { d) Elas não ___ (querer) ficar em casa. } \\
\text { e) Você__ (estudar) português no NEPPE? }\end{array}$ \\
\hline 4. Nos trabalhamos___ Construçä civil. & & f) A g gente____ (conhecer) o mercado da Asa Norte. \\
\hline 5. Elas trabalham ___ Ministério da Saúde. & & g) Eue elas ____ (morar) perto da rodoviária do Plano Pilloto. \\
\hline \multirow[t]{2}{*}{ 6. Eduardo e Lucia trabalham____ uma empress. } & & _(dormir) cedo. \\
\hline & & i) Nós não ___ (assistir) o jogo. \\
\hline
\end{tabular}

Fonte: Módulo Trabalho - Tuma Acolher I

A necessidade de trabalhar ou mesmo inserir no MD exercícios puramente gramaticais surgiu das próprias solicitações dos aprendentes, quando durante as aulas, ou mesmo nas extensões dessas, nos plantões, os aprendentes solicitavam exercícios desse caráter, sobretudo no início do curso.

Os aprendentes se apresentavam inquietos e exigiam geralmente explicitações no quadro de conjugações de verbos, descrições sobre a estrutura da língua portuguesa, de usos de preposições e artigos, dentre outros pontos gramaticais.

Mesmo sendo norteada por uma abordagem comunicativa, não hesitava em atender às solicitações e fazer explicitações e sistematizações gramaticais, mesmo porque Almeida Filho (2013) discorre que atender a essas demandas pode acalmar o coração do aprendente e assim baixar o filtro afetivo desse, possibilitando uma melhor aprendizagem e aquisição da língua.

Os aprendentes da turma analisada fizeram, durante as aulas, muitas solicitações de sistematizações gramaticais. Dentro do possível, tentei atender a essas, mas devido ao tempo de aula, pedi para que os aprendentes que demostravam muitas dúvidas e interesses em conteúdos mais gramaticais pudessem frequentar os plantões. Seguem algumas notas de campo que evidenciam essas solicitações e que apresentam as reflexões que tive na época: 
Figura 6 - Notas de campo do Acolher 1

\begin{abstract}
$3^{\text {a }}$ Aula- 31/03
Percebi que a necessidade de sistematizar momentos linguísticos e fonéticos foram importantes para dar mais segurança aos alunos.

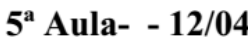

Um dos aprendentes, um haitiano, apresentou dúvidas sobre utilizar os verbos no presente e no passado e pediu se eu poderia escrever na lousa alguns verbos. Comecei a conjugar alguns verbos no presente do indicativo e mostrar a lógica dos verbos regulares. Fui interrompida por um aluno que pediu para que eu conjugasse também no passado. Normalmente, nesse inícios eu tinha a visão que era muita informação apresentar vários tempos verbais, no entanto, percebi que eles precisam e estão ansiosos para movimentar na língua para relatar fatos no presente e no passado, afinal de conta, a vida e os fatos passam em todos os tempos. Fiz a conjugação de alguns verbos tanto no presente quanto no passado e os aprendentes ficaram com os olhos quase imóveis de tanto que prestaram atenção, queriam copiar tudo do quadro.

Essa sistematização foi necessária pois deu um conforto aos estudantes.
\end{abstract}

Fonte: Registro da autora.

Pela nota de campo, pode-se observar que menciono esse "conforto" que a sistematização de pontos gramaticais deu aos aprendentes.

Vale remarcar que essas solicitações dizem muito sobre a cultura de aprender dos aprendentes, que, muitas vezes, acreditam, que para aprenderem uma língua estrangeira, é preciso saberem primeiro a gramática da língua e quando se deparam com um ensino mais voltado para o desenvolvimento da competência comunicativa, partindo de atividades que direcionam ao uso da língua, muitos apresentam resistência. Essa resistência pode atrapalhar e interferir no ensino-aprendizagem da língua-alvo.

Dessa maneira, é necessário que o profissional que esteja à frente desse ensino tenha sensibilidade e conhecimentos sobre o ensino-aprendizagem de línguas para que possa, da melhor maneira, tomar decisões para conduzir esse ensino e possibilitar reflexões com os aprendentes, para dialogar sobre os diferentes modos de ensinar e aprender línguas.

Outro ponto que friso é sobre os plantões, os quais começamos a oferecer a partir de 2015 , tendo em vista que, durante a aula, muitas vezes não conseguíamos acolher todas as demandas apresentadas pelos aprendentes. Destaco que os plantões contribuíram muito para desenvolver o ensino-aprendizagem no Módulo Acolhimento e colaboraram para a fluidez das aulas.

Retomando aos exercícios estruturais, nocionais e funcionais, esses eram realizados como tarefa de casa e eram corrigidos no início de cada aula. Os exercícios por si só não se 
mostraram de fato tão interessantes para aquisição real da língua, mas as correções desses foram bem proveitosas, pois se apresentavam como insumos para discussões de uso real da língua, tal como descrevo em uma nota de campo:

Figura 7 - Notas de campo do Acolher 1

\section{$4^{\mathrm{a}}$ Aula- - 05/04}

Iniciei a aula corrigindo os exercícios sobre fonética e a cada brecha e perguntas feitas pelos alunos aproveitava para trabalhar os sentido dos vocabulários, formulando frases e quais os usos reais daquela frase dentro de uma situação cotidiana. Ao terminar a correção, percebi que os alunos se dedicaram a estudar a atividade sobre fonética e já conseguiam distinguir as diferentes pronuncia dadas a letra $\mathrm{R}$ e $\mathrm{S}$, dando exemplos com palavras que eles conheciam.

Fonte: Registro da autora.

Como relatado na nota, os momentos de correções foram úteis para desenvolver os conteúdos de maneira mais significativa, mostrando exemplos de como são efetivamente usados num âmbito de uma comunicação real. Durante essas ocasiões muitos materiais foram criados de maneira improvisada em sala de aula.

No tocante à prática de letramentos, esses foram realizados a todo momento, quando agimos em sala, quando instruímos ou orientamos os aprendentes sobre como agir diante de uma prática social, tal como preencher uma ficha, enviar um curriculum, solicitar um exame médico, dentre outros atos socioculturais.

Tendo em vista que cada sociedade conduz e usa práticas sociais conforme a línguacultura e o contexto histórico da sociedade, o ensino-aprendizagem da língua se torna um meio eficaz e fértil para promover letramentos das práticas sociais que ocorrem nessa língua, contribuindo para promover uma aprendizagem e aquisição da língua mais significativa e real. Além disso, considero que o letramento de agires sociais possibilita ao aprendente mais autonomia para o uso da língua.

O MD foi um recurso que utilizamos para consolidar mais sistematicamente os letramentos e avaliá-los, para isso recorri aos gêneros textuais como insumos para efetivar práticas de letramentos.

A utilização dos gêneros textuais sempre esteve presente no MD. No módulo Apresentação havia o gênero biografia e no módulo de Trabalho constavam os gêneros: currículum, anúncio e classificado. 
Nessa última reelaboração feita dos módulos analisados, priorizei ainda mais esse trabalho com gêneros textuais. No módulo Apresentação continuei com gênero biografia, ampliando a possibilidade de desenvolvê-lo em diferentes situações, tais como em situações formais e informais, por meio de texto escrito e oral. Além disso, busquei por intermédio desse gênero realizar trocas culturais.

Vale destacar que nesses módulos preocupei-me em não consolidar estereótipos e discriminações. Atentei para construir um material que contemplasse uma pluralidade cultural e racial, assim como diversidade em papéis atribuídos a gêneros, com a finalidade de proporcionar maiores identificações com os aprendentes e, ao mesmo tempo, letramentos sobre a configuração da sociedade brasileira no tocante à diversidade cultural e às questões ligadas a gêneros e reflexões sobre processos interculturais. No quadro a seguir, sintetizo os aspectos que busquei desenvolver no gênero biografia:

Quadro 6: Aspectos do gênero biografia

\section{Gênero textual: Biografia (Escrito e Oral)}

\begin{tabular}{|c|c|c|}
\hline $\begin{array}{l}\text { Aspectos } \\
\text { linguístico- } \\
\text { comunicativo }\end{array}$ & $\begin{array}{l}\text { Aspectos de } \\
\text { letramentos }\end{array}$ & Aspectos de interculturalidade \\
\hline $\begin{array}{l}\text { - } \text { Perguntar e dizer o } \\
\text { nome } \\
\text { - } \text { Estado civil; } \\
\text { - Profissões } \\
\text { - Pronomes pessoais } \\
\text { - } \text { Veronomes de } \\
\text { apresentação no } \\
\text { presente do } \\
\text { indicativo } \\
\text { - Estrutura básica da } \\
\text { língua portuguesa; } \\
\text { - Frases } \\
\text { Interrogativas } \\
\text { negativas e } \\
\text { afirmativas; } \\
\text { Números; }\end{array}$ & $\begin{array}{l}\text { - Como preencher } \\
\text { uma ficha pessoal; } \\
\text { - Quais informações } \\
\text { apresentar em um } \\
\text { primeiro contato; } \\
\text { - Como fazer uma } \\
\text { apresentação oral } \\
\text { ao público } \\
\text { (seminário) }\end{array}$ & $\begin{array}{l}\text { - Maneiras de se cumprimentar } \\
\text { entre as culturas presente em } \\
\text { sala de aula; } \\
\text { - Gestos corporais brasileiros } \\
\text { cotidianos; } \\
\text { - Profissões e história de vida; } \\
\text { - Troca de informações pessoais } \\
\text { - Apresentação de personalidades } \\
\text { brasileiras que "representam" } \\
\text { áreas tais como: esporte, mídia- } \\
\text { novela, música, política, que } \\
\text { devem incitar um conhecimento } \\
\text { e uma troca cultural, na medida } \\
\text { que eles apresentam outras } \\
\text { personalidades do país de } \\
\text { origem. }\end{array}$ \\
\hline
\end{tabular}


No módulo Apresentação inseri biografias curtas sobre personalidades brasileiras, tais como Dayane dos Santos, que foi uma ginasta brasileira, que veio de origens humildes, de cor negra e que conseguiu conquistar e construir uma carreira de sucesso e brilhantismo por sua habilidade de ginástica e perseverança.

Apresentei Dilma Roussef, que foi a Presidenta do Brasil, de origem imigrante, de cor branca e que construiu uma carreira como mulher política passando por diversos desafios tanto por ideias quanto pelo fato de pertencer ao gênero feminino.

Também foram inseridos Chico Buarque e Marisa monte, cantores brasileiros e reconhecidos internacionalmente pelas composições musicais e, no caso do artista Chico Buarque, pela literatura. Lázaro Ramos também foi apresentado como ator brasileiro e apresentador, reconhecido por participar de vários filmes brasileiros e novelas. E, por fim, na tarefa avaliativa trabalhei com a personalidade de Edson Arantes do Nascimento, conhecida mundialmente como Pelé, Rei do futebol.

Empenhei-me em desenvolver o trabalho com as personalidades por um viés intercultural e não apenas de apresentação. Não tive muito sucesso com todas as personalidades, mas, em algumas, a interculturalidade pôde acontecer. A nota de campo a seguir mostra um desses momentos:

Figura 8 - Notas de campo do Acolher 1

\section{AULA- 19/04}

Aproveitei a figura da presidenta para perguntar aos alunos sobre os presidentes/tas dos países deles. Muitos estudantes, sobretudo, os haitianos, falaram sobre a situação do país de origem. Notei que alguns aprendentes eram bem engajados politicamente e tentaram me explicar o que acontecia no Haiti.O aluno de Gana também falou um pouco e a aluna da Zâmbia tentou falar, mas não conseguiu falar em português e continuou toda a fala em inglês.

Foi um momento muito enriquecedor, pois ouvi sobre a história do Haiti, Gana e Zambia. Esse momento me possibilitou conhecimentos e sentimentos que não estão em livros.

Alguns apresentes reconheceram o artista Lazaro Ramos em propagandas, isso mostra que já estão começando a ter mais familiaridade com a atmosfera brasileira.

Fonte: Registro da autora.

$\mathrm{Na}$ medida em que eu apresentava as personalidades brasileiras, eu solicitava aos aprendentes que compartilhassem sobre as personalidades que eles admiravam do país de origem deles ou mesmo qualquer outra personalidade. Alguns aprendentes interagiam, principalmente os haitianos que eram a maioria dos estudantes da turma. 
A personalidade mais reconhecida foi a apresentada na tarefa avaliativa, o Rei Pelé. Nessa tarefa, os estudantes deveriam escrever uma biografia sobre o Pelé com as informações oferecidas e em seguida apresentar uma personalidade do país deles. Além da apresentação escrita, eles deveriam fazer uma apresentação oral para todos os colegas da sala. Segue abaixo os textos de dois aprendentes da turma referente a essa tarefa:

Figura 9 - Módulo Trabalho - textos dos aprendentes- Biografia
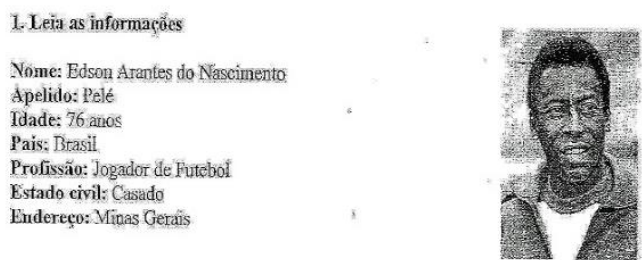

Elahore um texto com as informaç̄es sohre PELE

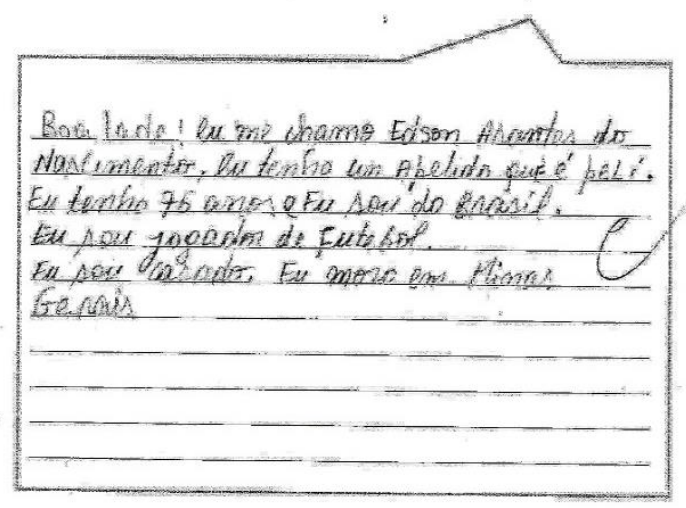

2. Escollha uma personalidade famosa de sea país $e$ apresente sobre ela:

Nome: Anderson thichat

Apelido: $\operatorname{sen} 58 \pi$

Idade: 37 onos

Pais: hoití

Profissäo: Contor

Estado Civil: Coscodo

Elabore un texío com as informaçóes dessa Personalidade e apresente aos collegas:

Mar nome é Anderson Michele eu ten ho um opelido que é nonson.

eu tenho 37 anos e eu bou do fouts.

us bou contor. Sor cono-do.? 

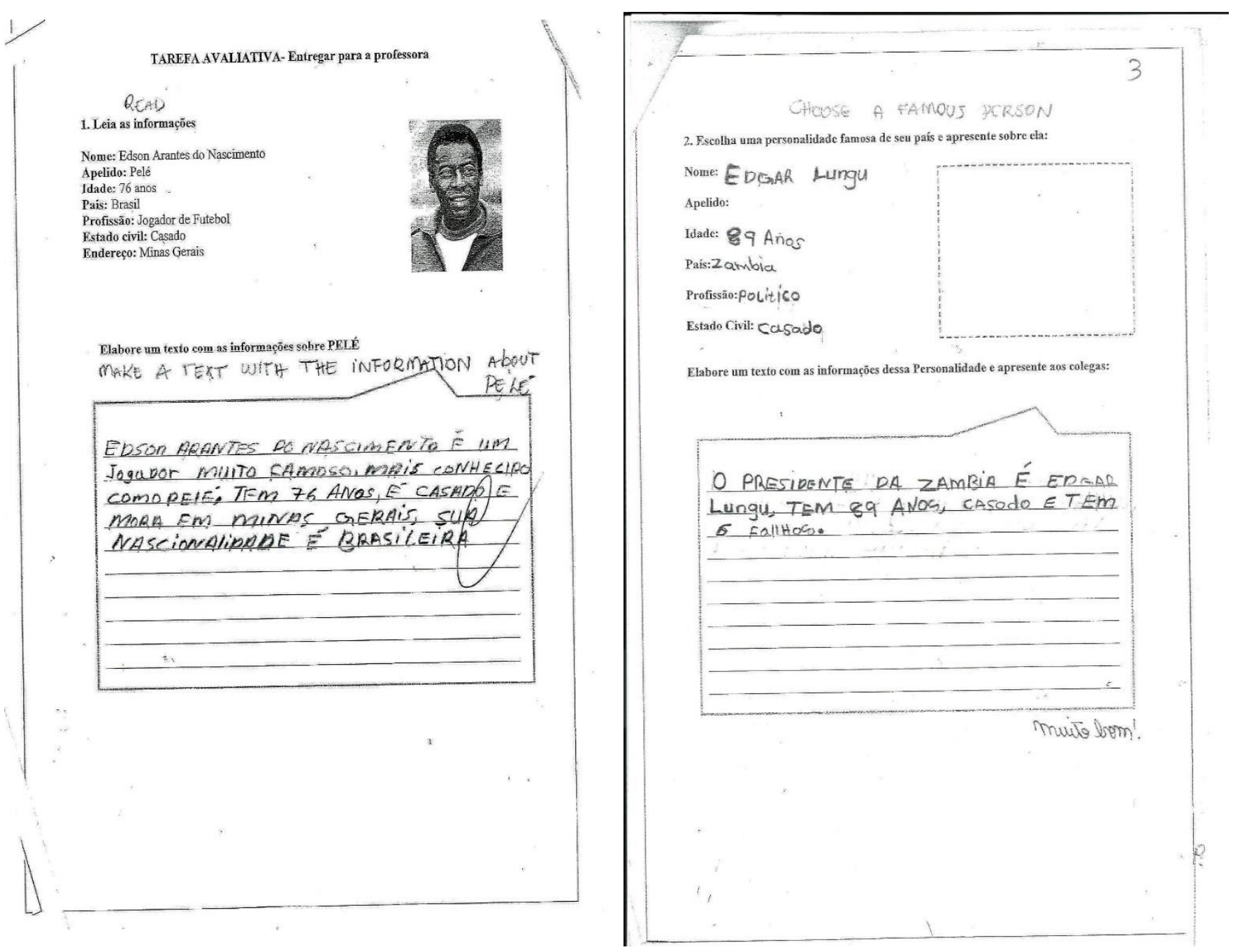

Fonte: textos produzidos em sala.

Essa tarefa se apresentou produtiva tanto para desenvolver a aquisição da língua, quanto letramentos do gênero biografia e promover interculturalidades. Houve um momento interessante durante essa atividade que relato a seguir.

Durante a apresentação oral que os aprendentes fizeram sobre as personalidades que eles escolheram escrever, um estudante de Gana iniciou a apresentação falando sobre o Presidente de Gana; esse estudante estava aparentemente nervoso para a apresentação. Um outro estudante, de outra nacionalidade, tendo a percepção que o colega de sala estava ansioso, levantou-se e o ajudou na apresentação. Foi um ato solidário e todos os demais aprendentes ficaram ainda mais atentos para as apresentações de maneira que eles se ajudavam. 
Tenho notado que essa ajuda entre aprendentes contribui muito para o desenvolvimento da aquisição da língua e também para ocasionar momentos de trocas culturais, de respeito, de identificações e acolhimento.

Nessa turma, pude reconhecer diversos momentos de acolhimento entre eles, os quais me motivaram a trabalhar ainda mais com dinâmica em pares. Essas dinâmicas resultaram em ações positivas para o ensino e para o ritmo da aula, pois proporcionaram o compartilhamento de aprendizagens, de trocas culturais, de identificações, de ações acolhedoras e solidárias, além disso, contribuíram para formar redes de amizades dentro da sala de aula, o que contribui para tornar esse ambiente mais acolhedor e divertido.

Referente ao módulo Trabalho, os gêneros desenvolvidos foram: anúncios de emprego; e-mail; curriculum; portfólio; cartazes de publicidades, entrevista oral, poema e fábula. Neste estudo, analisarei somente os quatro primeiros gêneros mencionados, pois eles resultaram materiais (textos) para análise, os demais estão no material didático, no entanto, não foram desenvolvidos, em consequência da falta de tempo nas aulas. Tentei priorizar os gêneros que os aprendentes mais usariam no dia-a-dia.

Destaco que nesse módulo Trabalho as práticas de letramento sobre ações cotidianas e práticas sociais, especialmente em atividades escrita, leitura e oral puderam ser melhor aprofundadas, pois os aprendentes já conseguiam compreender um pouco mais da língua portuguesa.

Os gêneros foram selecionados, tendo em vista o tema do módulo e a necessidade dos aprendentes de saberem como se movimentarem diante desses gêneros textuais imprescindíveis para uma melhor inserção laboral.

Em cada gênero busquei desenvolver aspectos linguístico-comunicativos; aspectos de letramentos e aspectos de interculturalidade. Os quadros a seguir buscam sintetizar os aspectos que foram desenvolvidos em cada um desses gêneros: 
Quadro 7 - Aspectos do gênero anúncio e classificado

\begin{tabular}{|c|c|c|}
\hline \multicolumn{3}{|c|}{ Gênero textual: ANÚNCIO E CLASSIFICADO DE JORNAL } \\
\hline $\begin{array}{l}\text { Aspectos } \\
\text { linguístico- } \\
\text { comunicativo }\end{array}$ & $\begin{array}{l}\text { Aspectos de } \\
\text { letramentos }\end{array}$ & $\begin{array}{c}\text { Aspectos de } \\
\text { interculturalidade }\end{array}$ \\
\hline $\begin{array}{l}\text { Verbos: procurar, } \\
\text { precisar, contratar } \\
\text { - Vocabulários e } \\
\text { siglas: } \\
\text { s/c/experiência; } \\
\text { - Adjetivos: } \\
\text { proativo, } \\
\text { dinâmico, } \\
\text { pontual; } \\
\text { Horas e dias da } \\
\text { semana. }\end{array}$ & $\begin{array}{l}\text { - Identificar } \\
\text { informações: } \\
\text { cargo/vaga, locais } \\
\text { de trabalho, } \\
\text { requisitos } \\
\text { (c/exp.), contato } \\
\text { (e-mail, telefone); } \\
\text { - Locais onde } \\
\text { procurar } \\
\text { anúncios: jornal, } \\
\text { vitrines de locais } \\
\text { ou nas portas, } \\
\text { classificados } \\
\text { específicos, sites } \\
\text { de emprego; } \\
\text { Como funciona o } \\
\text { sistema de } \\
\text { educação } \\
\text { brasileira e } \\
\text { acesso: } \\
\text { Leis trabalhistas } \\
\text { brasileiras } \\
\text { (direitos e } \\
\text { deveres: salário, } \\
\text { benefícios); } \\
\text { Maneiras e } \\
\text { hábitos em locais } \\
\text { de trabalho e } \\
\text { estudo; } \\
\text { Como proceder } \\
\text { diante de uma } \\
\text { entrevista de } \\
\text { emprego. }\end{array}$ & $\begin{array}{l}\text { - Formação e } \\
\text { experiências } \\
\text { profissionais dos } \\
\text { alunos no país de } \\
\text { origem e atualmente; } \\
\text { - Sonhos e ambições } \\
\text { - Calendário } \\
\text { brasileiro. }\end{array}$ \\
\hline
\end{tabular}

Fonte: Elaborado pela autora

Iniciei com o gênero anúncio e classificados de jornal, pois, por meio dele pude trabalhar diversos assuntos de acordo com as informações expressas nesse gênero, como, por exemplo, formação e experiências de profissionais, locais de trabalho, benefícios e deveres do 
trabalhador, profissões e suas funções, dentre outras que podem ser observadas no quadro apresentado.

Esse gênero foi propulsor para o desenvolvimento dos demais gêneros. O segundo gênero trabalhado foi o e-mail:

Quadro 8 - Aspectos do gênero e-mail

\begin{tabular}{|c|c|c|}
\hline \multicolumn{3}{|c|}{ Gênero textual: E-MAIL } \\
\hline $\begin{array}{l}\text { Aspectos } \\
\text { linguístico- } \\
\text { comunicativo }\end{array}$ & $\begin{array}{l}\text { Aspectos de } \\
\text { letramentos }\end{array}$ & $\begin{array}{c}\text { Aspectos de } \\
\text { interculturalidade }\end{array}$ \\
\hline $\begin{array}{l}\text { Vocativos formais e } \\
\text { informais; } \\
\text { - Linguagem formal e } \\
\text { informal; } \\
\text { - Despedidas. }\end{array}$ & $\begin{array}{l}\text { Função social desse } \\
\text { gênero, o espaço e a } \\
\text { utilização dele na } \\
\text { sociedade brasileira; } \\
\text { - Identificar } \\
\text { caraterísticas desse } \\
\text { gênero e como } \\
\text { elaborar, respeitando a } \\
\text { estrutura go gêneros; } \\
\text { - Quais informações } \\
\text { devem conter em um e- } \\
\text { mail; } \\
\text { - Pontos de acesso para } \\
\text { internet pública; } \\
\text { O uso da internet no } \\
\text { Brasil. }\end{array}$ & $\begin{array}{l}\text { - Maneiras e forma mais } \\
\text { utilizadas para } \\
\text { comunicação no Brasil } \\
\text { e no país dos alunos; } \\
\text { - A relação de contato } \\
\text { com meios digitais e } \\
\text { tecnológicos. }\end{array}$ \\
\hline
\end{tabular}

Fonte: Elaborado pela autora

Esse gênero se apresentou como uma novidade para alguns estudantes que nunca tiveram contato com esse tipo de texto, tanto que antes de desenvolvê-lo, ajudei alguns aprendentes a abrirem uma conta de e-mail. Esse momento foi importante para perceber como um ato aparentemente simples para alguns, ter um e-mail, para outros não era tão simples. Uma das aprendentes que ajudei ficou tão feliz em ter um e-mail que, durante a sala, ela queria passar o endereço de e-mail para todos os colegas. 
Esses dois gêneros foram exercitados durante as aulas, no entanto, para avaliá-los mais concretamente, preparei uma atividade que consistia em identificar informações sobre um anúncio de emprego e em seguida escrever um e-mail mostrando interesse na vaga do anúncio. Segue abaixo a tarefa de dois aprendentes:

Tarefa avaliativa-Módulo trabalho

1. Ligue o sentido de cada palavra:
1. Salário
2. Beneficios
(3) Dinheiro que recebe ao final do ano
3. Décimo terceiro
4. Carteira de trabalho
5. Férias
6. Hora extra
(5) Descanso.
(4) Documento de trabalho formal .
(1) Dinheiro que recebe an final do mês.
(2) Vale transporte, vale alimentação.
(6) Trabalha mais que 8 horas por dia.

2. Leia o anúncio de trabalho e preencha a ficha com as informaçóes fornecidas neste:

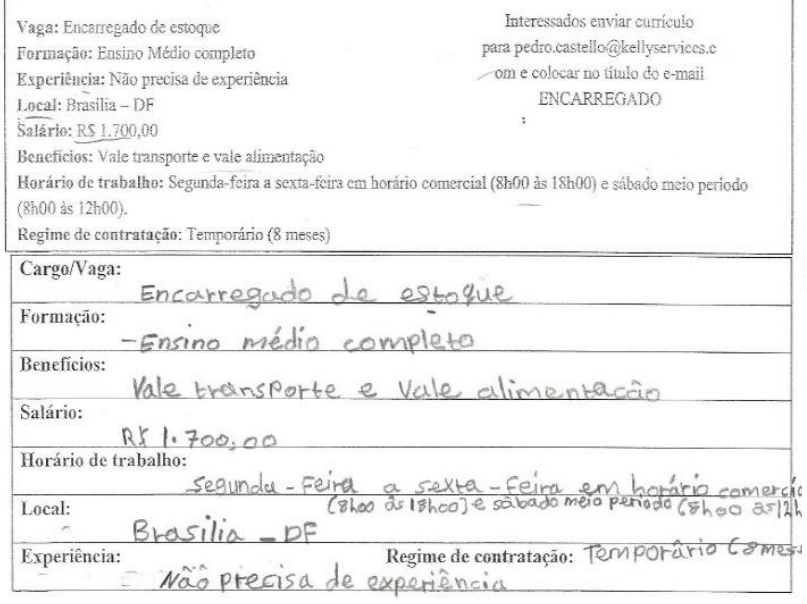

Geressados eliviar cumicuto para pedoc.castello@ikellyservices.c ENCARREGADO

Figura 10 - Módulo Trabalho - textos dos aprendentes - Anúncio e E-mail

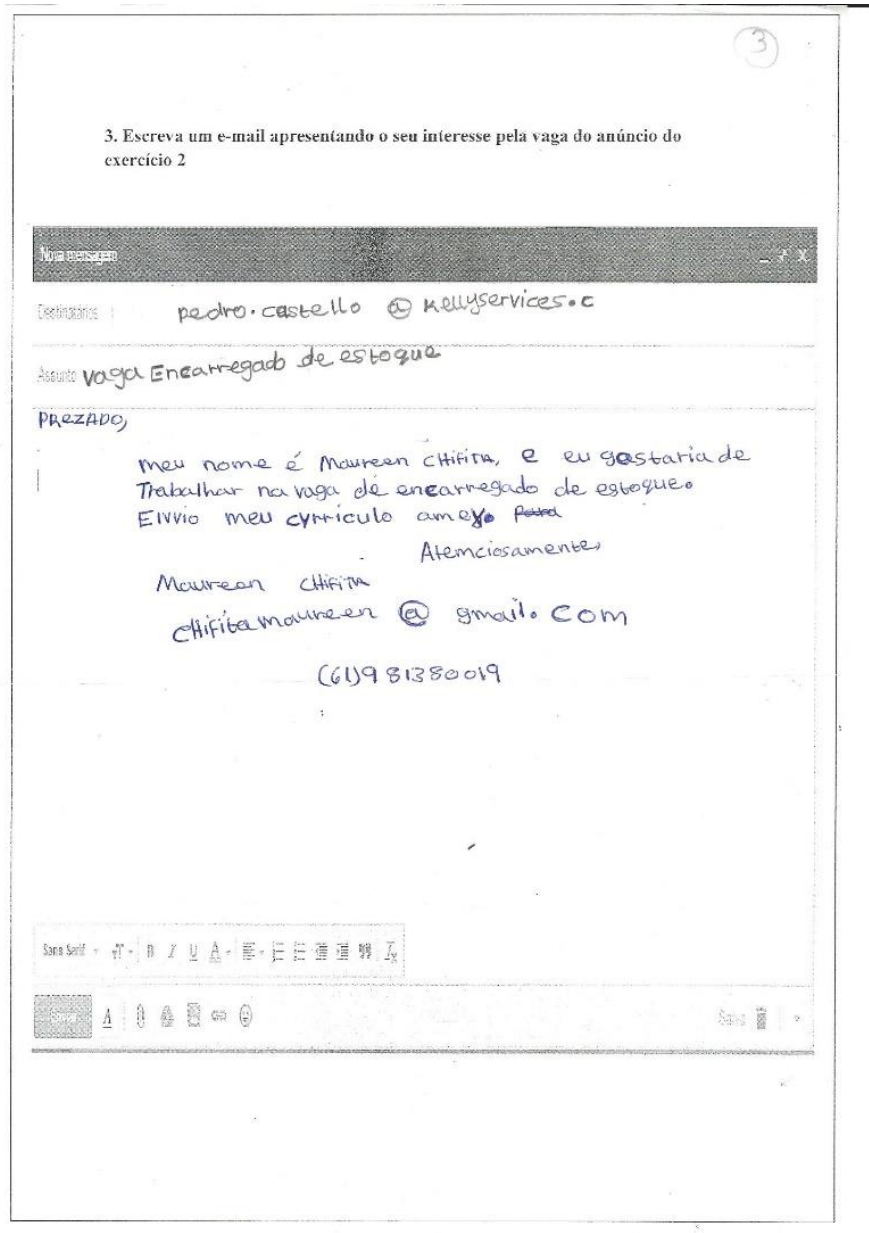




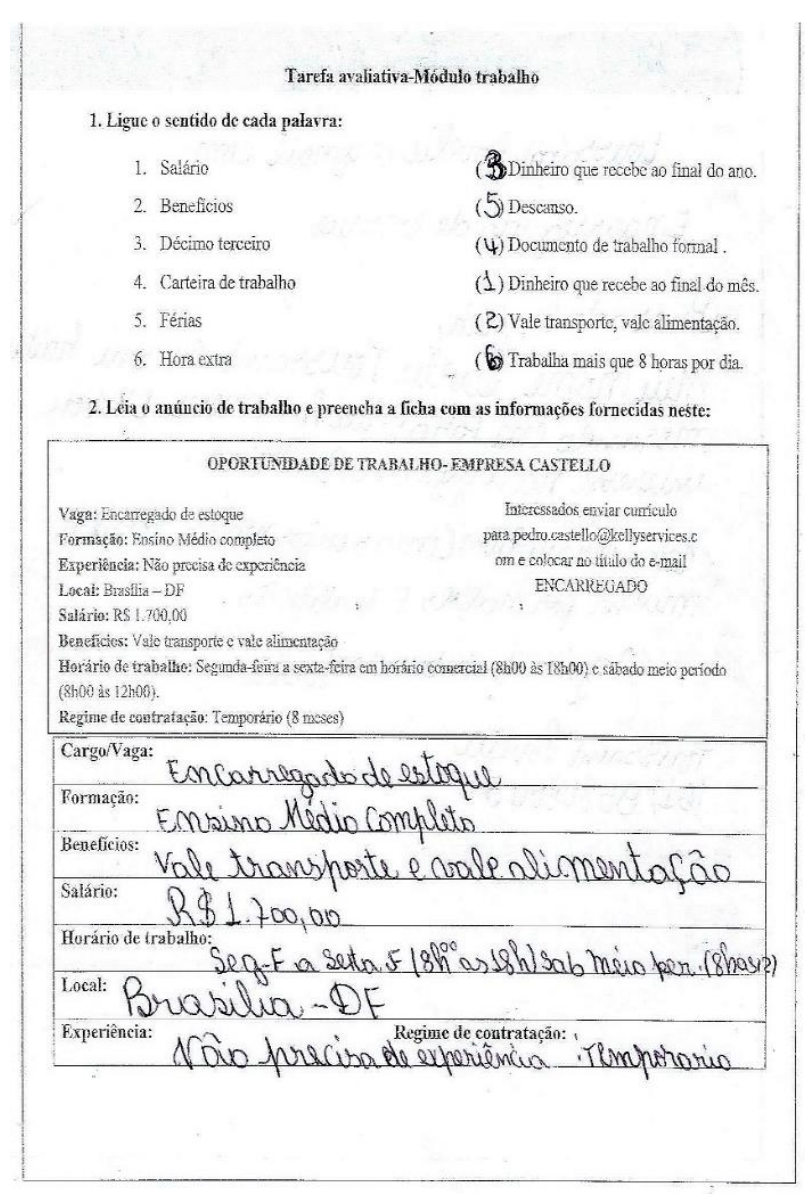

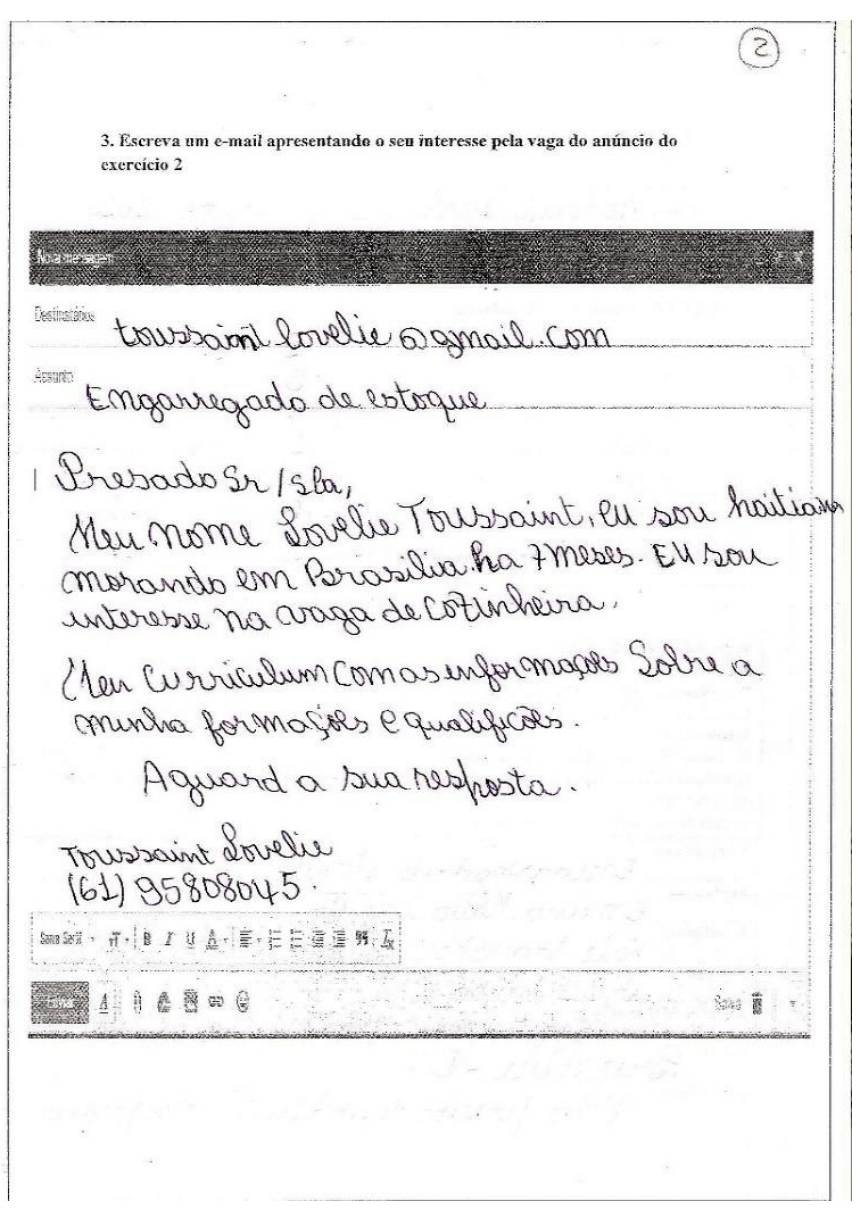

Fonte: Textos produzidos em sala.

Considero que o trabalho com gêneros contribuiu para um ensino-aprendizagem mais significativo e eficaz, uma vez que os gêneros textuais, de acordo com Marcushi (2010), são "maleáveis", isto é, são criados e utilizados de acordo com a necessidade de comunicação do indivíduo.

Outra autora que corrobora a eficácia do uso de gêneros textuais para ensino de língua é Tossati (2009, p.02) que afirma que "o trabalho com GTs em aulas de língua estrangeira fazse coerente com a proposta de estimular e encorajar o aluno na participação das atividades, além de ser um facilitador do processo de inserção do aprendiz na língua-alvo”.

Tenho a dizer que as atividades com gêneros textuais têm se mostrado interessantes e eficazes para atender as especificidades e os objetivos do ensino e dos aprendentes, pois têm permitido promover uma aprendizagem que auxilie o aprendente a adquirir português nos seus diversos aspectos, tais como: instrumento de comunicação, como meio de inserção nas práticas socioculturais ligadas a domínios da vida cotidiana. Além disso, o ensino com gêneros textuais 
tem possibilitado de maneira mais sistemática desenvolver competências de escrita, de leitura e de oralidade, de maneiras mais significativas.

Nesse módulo trabalho desenvolvemos também o gênero curriculum e portfólio. $\mathrm{O}$ curriculum tem sido de extrema necessidade para auxiliar os aprendentes a conseguirem um emprego, haja vista a utilidade desse gênero nas práticas sociais.

O gênero portfólio foi inserido nessa última reelaboração como um gênero mais informal, tanto que as perguntas propostas são mais pessoais e até mesmo subjetivas. Os quadros a seguir buscam sintetizar os aspectos que foram desenvolvidos em cada um desses gêneros:

Quadro 9 - Aspectos do gênero Curriculum

\begin{tabular}{|c|c|c|}
\hline \multicolumn{3}{|c|}{ Gênero textual: CURRÍCULUM } \\
\hline $\begin{array}{l}\text { Aspectos } \\
\text { linguístico- } \\
\text { comunicativo }\end{array}$ & $\begin{array}{l}\text { Aspectos de } \\
\text { letramentos }\end{array}$ & $\begin{array}{c}\text { Aspectos de } \\
\text { interculturalidade }\end{array}$ \\
\hline $\begin{array}{l}\text { - Identificar comandos; } \\
\text { - Adjetivos; } \\
\text { - Números }\end{array}$ & $\begin{array}{l}\text { Reconhecer formação } \\
\text { ou escolaridade dentro } \\
\text { do contexto brasileiro; } \\
\text { - Saber identificar } \\
\text { habilidades pessoais; } \\
\text { - Saber elaborar um } \\
\text { curriculum. }\end{array}$ & $\begin{array}{l}\text { Trocas de experiências } \\
\text { de trabalho e formação } \\
\text { no país de origem; } \\
\text { - Habilidades pessoais; } \\
\text { - Compartilhar de } \\
\text { Idiomas e língua falam } \\
\text { no país de origem } \\
\text { - Aspectos históricos } \\
\text { relacionados a língua, } \\
\text { - Profissões mais } \\
\text { comuns nos países. }\end{array}$ \\
\hline
\end{tabular}

Fonte: Elaborado pela autora

A produção desse gênero apresentou algumas dificuldades, especificamente quando os aprendentes recuperavam na memória as experiências profissionais que haviam tido nos países de origem deles, eles tinham dificuldades em falar sobre, tanto dificuldades em se expressarem na língua portuguesa quanto na recuperação das memórias. Como havia 16 estudantes na turma, ficou difícil para eu poder atender, escutar pacientemente as experiências de cada aprendente, foi então que levei esse gênero para as atividades interculturais que serão descritas e analisadas neste estudo. Apresento a produção de dois aprendentes relacionada ao gênero curriculum realizada em sala de aula. 
Figura 11 - Módulo Trabalho - Textos dos aprendentes - Curriculum Vitae

Curriculum vitae

Telefone: 161$) 95808045$

E-mai: toussant lovelie $@$ gmail. com

Endereç: Paranoá cony I, Quadra 10

Dados Pessuais

Data de nascimento: $02 / 12 / 87$

Nacionalidade: Houttana

Estado chili: soltura

Carteira de trabalho: (U) sim () ) nă

Carteira: de motorista válida no Brasil: ( ) sim ( $\nvdash_{\text {não }}$

Escolaridade

(1) Ensino Fundamenta

( ) Ensino Média

(v) Superior em fred a gagual

Realizou algum curso técnico? ( () Sim ( ) Não

curso: Inforomatica

Idioma

Língua materna:

Português: ( $Y$ básico ( ) intermediário ( ) avançado

Inglês: ( ) básico ( ) intormediário ( ) avançado

Francês: ( ) básico ( ) intermediário ( $V$ ) avançado

Espanhol: ( ) básico () intermediário () avançado

Experiência de Trabalho

(ordem decrescente)

Funçä́o/atividade: Aux de cozinha

Periodo de trabalto: ? Meses

Local: Tempero Capital

(ordem decrescente) forf fan Jan Nor

Empregador: Jar aro/atividade: Proferbor do de Crianca

Periodo de trabalho: 4 aners

Local: Laferonay Acade mie de la for

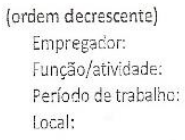

Conhecimento de informática

MWord (ViExcel () Internet

Outras habilidàdes pessoais

Obs:

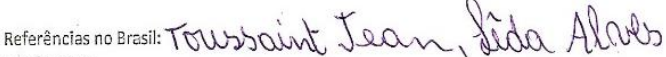
Local e Data:

Assinatur: Iowssaint forelie 


\section{Curriculum Vitae}

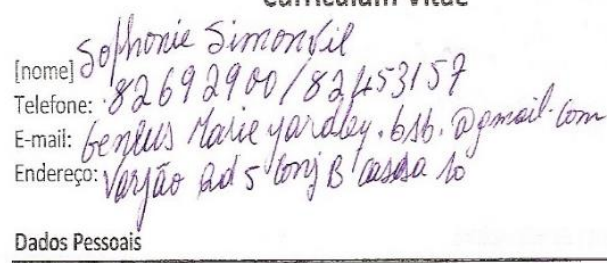

(d) Superior em Acieneses exkou magem nấo diftômen

Realizou algum curso técnico? ( $\alpha) \operatorname{sim}($ ) Não

Curso: Linqua portugues

Local: NEppe/UnB

Idiomas

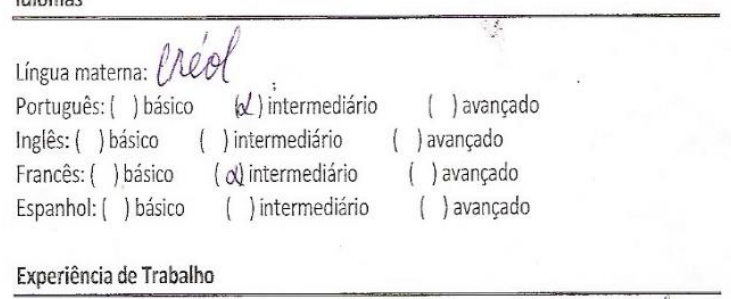

cordem decrescente) sital claine hewrewse de Dessaline. do Hait Empregador: hos pita chäatividade: Como exfermeina período de trabalho: um ( 1 ) anos Local: Hoiti

(ordem decrescente) it al: Centre de santé portail de Légeane Empregador: hospitar : enfermelua Função/atividade: Como enpen. Local: Heiti

Fonte: textos produzidos em sala.

Como mencionado, essa elaboração do curriculum foi realizada duas vezes, uma em sala de aula e outra na atividade intercultural Despertar Profissional. Os textos apresentados nesta dissertação foram realizados em sala de aula e escritos à mão pelos aprendentes que 
contaram com uma breve ajuda de minha parte. $\mathrm{Na}$ atividade Despertar Profissional, a realização desse gênero foi feita com o auxílio dos brasileiros e de maneira digitalizada. Todos os aprendentes receberam três cópias digitalizadas do curriculum que produziram na atividade.

No que concerne ao gênero portfólio, os aspectos desenvolvidos foram:

Quadro 10 - Aspectos do gênero Portfólio

\begin{tabular}{|c|c|c|}
\hline \multicolumn{3}{|c|}{ Gênero textual: PORTFÓLIO } \\
\hline $\begin{array}{l}\text { Aspectos } \\
\text { linguístico- } \\
\text { comunicativo }\end{array}$ & $\begin{array}{l}\text { Aspectos de } \\
\text { letramentos }\end{array}$ & $\begin{array}{c}\text { Aspectos de } \\
\text { interculturalidade }\end{array}$ \\
\hline $\begin{array}{l}\text { - } \text { Formular frases, } \\
\text { - Identificar perguntas; } \\
\text { - } \text { Vocabulários de } \\
\text { adjetivos, }\end{array}$ & $\begin{array}{l}\text { - Como elaborar uma } \\
\text { apresentação: quais } \\
\text { informações } \\
\text { realmente são } \\
\text { importantes } \\
\text { compartilhar e } \\
\text { enfatizar; } \\
\text { - Reconhecer } \\
\text { habilidades pessoais e } \\
\text { profissionais que } \\
\text { serviam para uma } \\
\text { possibilidade de } \\
\text { trabalho nessa } \\
\text { trajetória de vida no } \\
\text { Brasil; } \\
\text { Quais profissões no } \\
\text { Brasil são mais } \\
\text { acessíveis e tem mais } \\
\text { demanda procura. }\end{array}$ & $\begin{array}{l}\text { - Histórias e trajetória } \\
\text { de vida; } \\
\text { - Sonhos, habilidades } \\
\text { dos alunos; } \\
\text { - Motivos de vinda } \\
\text { para o Brasil: social, } \\
\text { pessoal, econômica. }\end{array}$ \\
\hline
\end{tabular}

Fonte: Elaborado pela autora

O portfólio se apresentou como um gênero novo, tanto para os aprendentes quanto para mim. Quando pensei em inseri-lo foi visando possibilitar o contato com um gênero que não fosse tão formal e que pudesse ser utilizado para um futuro projeto de inserção dos imigrantes e refugiados no mercado de trabalho.

Esse projeto consistia em fazer um grande portfólio apresentando os profissionais que tínhamos no curso Módulo Acolhimento, deixando disponíveis, talvez online ou mesmo por meio de impressos, para empresas interessadas. O projeto, infelizmente, ainda está no papel.

No entanto, a experiência com o portfólio foi realizada. Houve dificuldades na 
elaboração desse gênero, especificamente na parte em que eles precisavam escrever sobre "habilidade" e "um sentimento". Apresento a seguir textos dos aprendentes.

Figura 12 - Módulo Trabalho - textos dos aprendentes- Anúncio e E-mail

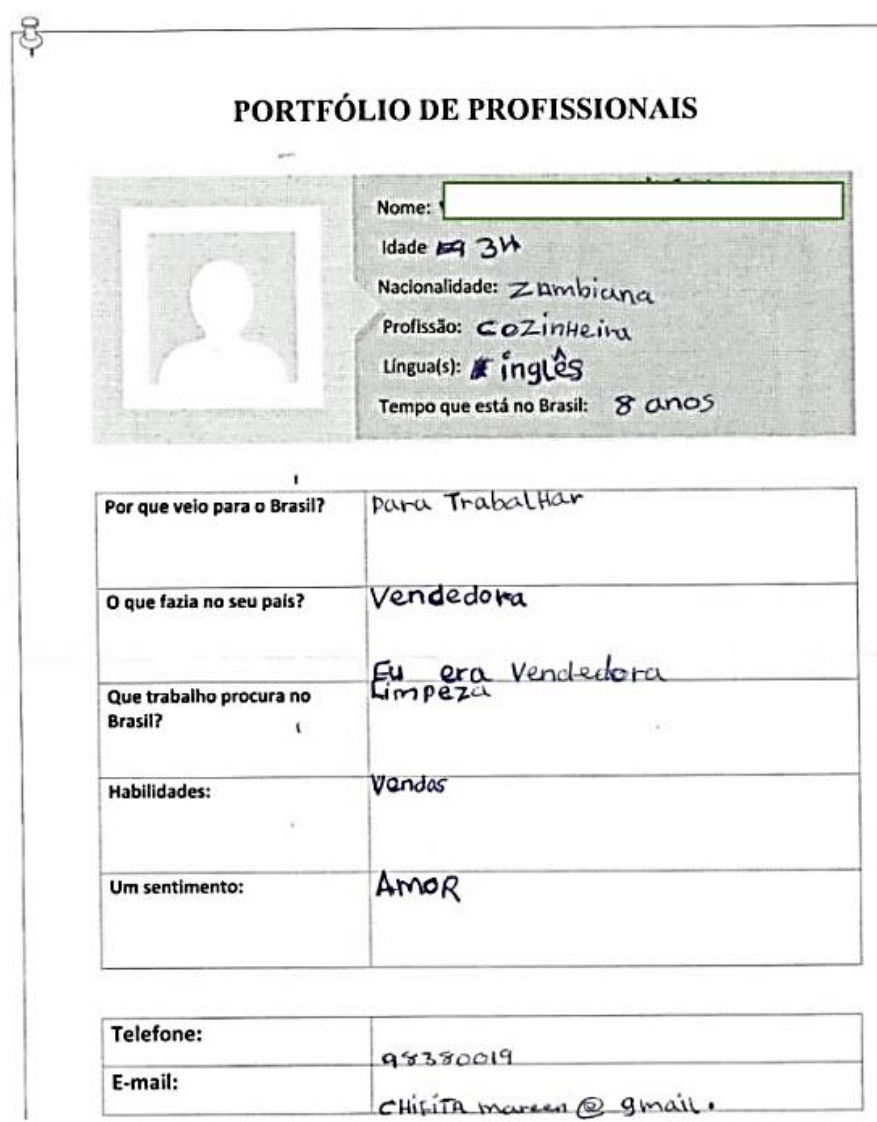

\section{PORTFÓLIO DE PROFISSIONAIS}
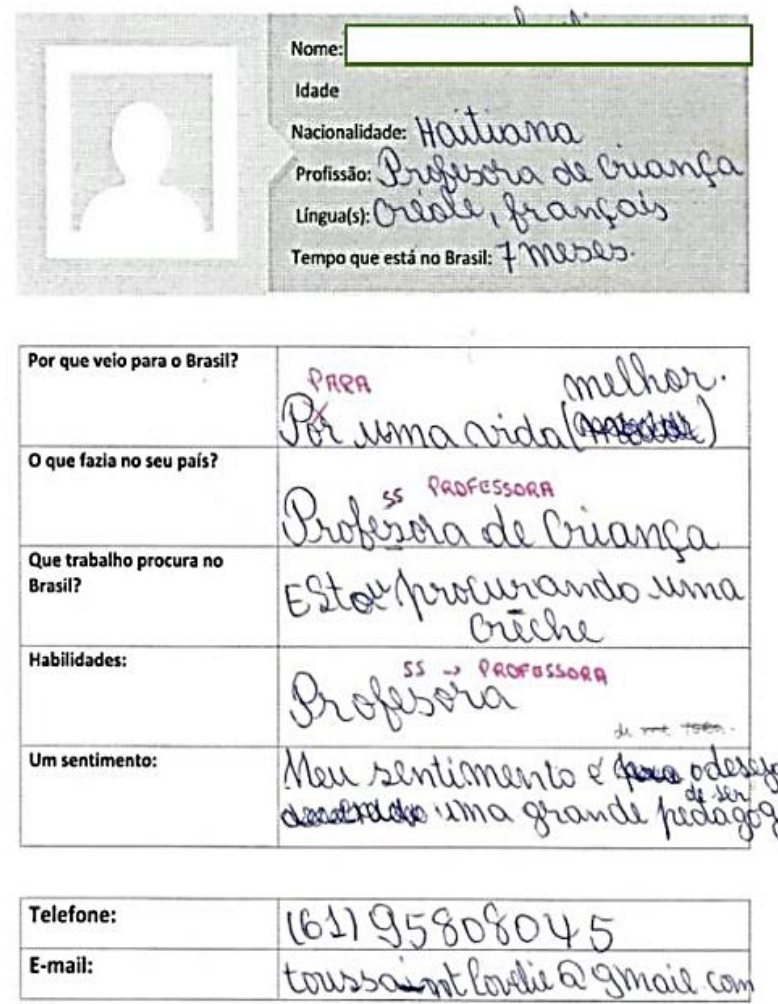

Fonte: textos produzidos em sala.

Esses dois últimos gêneros foram praticados em sala de aula e também na atividade intercultural Despertar do Profissional.

A utilização dos gêneros textuais nos módulos do material didático do Acolher 1 foi eficaz, na medida que conseguiu com alguns sucessos atender aos objetivos do ensino proposto para essa turma: propiciar um ensino-aprendizagem entrelaçado com letramentos de práticas socioculturais e a mediação de trocas culturais. Além disso, possibilitou desenvolver competência de uso do português nas competências de escrita, leitura e oral.

Considero que os módulos analisados foram produtivos para o nosso ensino, no entanto, reconheço que alguns pontos, sobretudo nos aspectos da interculturalidade, devem ser melhor 
desenvolvidos ou mesmo modificados, para que não fiquem apenas como apresentação, mas que consigam extrapolar esse sentindo, como aconteceu em alguns momentos.

Antes de passar para a análise das atividades interculturais, acredito ser relevante frisar que, no Módulo Acolhimento, o ensino-aprendizagem da língua é conduzido na língua-alvo, no caso, na língua portuguesa. No entanto, quando preciso, sobretudo no nível iniciante, Acolher 1, há momentos que o professor precisa recorrer a uma língua franca para explicar algum conteúdo e passar informações importantes e que não foram bem compreendidas.

Tendo em vista essa recorrência a uma língua franca, é desejável que o docente que esteja à frente desse ensino, principalmente nas turmas de nível iniciante, tenha conhecimentos e aquisição de uma ou até mesmo de duas línguas estrangeiras.

Na turma analisada, não tive tantos problemas em estabelecer comunicação em outras línguas (no caso no francês ou no Inglês), pois a maioria falava o francês ou o Inglês. No entanto, em outras turmas do Acolher 1 em que lecionei, tive dificuldades de comunicação com alguns aprendentes que tinham como língua materna a língua Árabe. Alguns desses aprendentes não tinham proficiência na língua inglesa, eles sabiam outras línguas como Urdo e Pastho, porém eu não tinha/tenho conhecimento na língua Árabe ou na língua Urdo ou na língua Pastho. Dessa forma, a maneira que encontrei para me comunicar foi por meio do auxílio de outros aprendentes de língua materna Árabe e que sabiam o Inglês. Esses aprendentes me ajudavam a estabelecer comunicação em determinados momentos, seja na sala de aula para explicar algum conteúdo ou nos atendimentos fora de sala.

Dessa maneira, nessa reelaboração dos módulos do MD tentei construir atividades e inserir gêneros a fim de propor um ensino que se atentasse para a aprendizagem e aquisição da competência de uso da língua-alvo, juntamente com o letramento das práticas sociais e com o conhecimento e compreensão das culturas da nova língua, para que assim o(a)s aprendentes, de acordo com Almeida Filho (2011, p. 52), possam “circular socialmente nessa língua-alvo pretendida e para nela fazer coisas ou obter efeitos", possibilitando a esses a autonomia tanto para o uso da língua como para o conhecimento e inserção nas práticas socioculturais presentes no dia a dia da nova sociedade. 


\subsection{Análise das Atividades interculturais}

\subsubsection{Descrição das Atividades interculturais}

$\mathrm{Na}$ tentativa de concretizar os objetivos propostos neste estudo para o ensinoaprendizagem de português para o Acolher 1, reelaborei os módulos apresentados e analisados na seção 4.1.1 No entanto, por conhecimentos teóricos (Almeida Filho 2011, Vilaça 2009, dentre outros) e também por experiência docente, sabe-se que o MD constitui-se como um recurso, tendo por função básica auxiliar o processo de ensino-aprendizagem, contribuindo, de acordo com Vilaça $(2009$, p.07) “de formas variadas para que a aprendizagem seja bemsucedida e, se possível, rápida, prazerosa e significativa".

Além do material didático, segundo a OGEL, há outras materialidades que envolvem o ensino de línguas, tais como procedimentos para experienciar a língua-alvo e avaliações.

Nessa seção me proponho a analisar um dos procedimentos para experienciar o português que desenvolvemos no Módulo Acolhimento. Esses consistiram na realização de duas atividades nomeadas Interculturais - Chá\&Prosa e Despertar Profissional.

Vale destacar que essas atividades constituíram-se como uma extensão dos módulos desenvolvidos na turma do Acolher 1 , no entanto, elas contaram com a participação de todas as turmas (acolher 1, acolher 2 e acolher 3) do curso Módulo Acolhimento e também com refugiados e imigrantes que foram convidados para participar das ações, mesmo esses não estando inscritos no curso, além disso, convidamos brasileiros para participarem.

As atividades interculturais também tiveram por finalidade atender aos objetivos propostos neste estudo de possibilitar momentos para praticar português, para desenvolver letramentos sobre práticas sociais e para promover interações e trocas culturais entre os aprendentes e os brasileiros convidados a participarem das atividades.

Visando atender a todos os estudantes do curso da melhor forma possível e dentro dos recursos financeiros e humanos que tínhamos, as atividades interculturais foram organizadas com antecedência. Ressalto que para a realização dessas atividades contei com o auxílio de toda a equipe do curso, com os funcionários do IMDH e com voluntários brasileiros que se interessaram em nos ajudar, especialmente do grupo de jovens e adultos Demonstre Amor Amando $^{31}$.

\footnotetext{
${ }^{31}$ Organização de jovens e adultos sem fins lucrativos de Brasília que conheci por indicações de amigos e que esteve presente nas duas atividades, nos auxiliando com lanche ofertado ao final das atividades e com a disponibilidade para a participação.
} 
Esse grupo de jovens esteve presente nas duas atividades, nos oferecendo o lanche e registrando em fotos toda a ação, além disso, a maior parte dos brasileiros presentes nessas atividades eram participantes desse grupo.

Para cada atividade elaborei um planejamento, descrevendo os objetivos e os procedimentos das ações (enviei por e-mail esse planejamento aos participantes brasileiros que nos confirmaram presença para que eles pudessem compreender mais detalhadamente as ações).

Apresento a seguir os planejamentos:

Figura 13 - Planejamentos das Atividades Interculturais

\section{Planejamento da Atividade "CHÁ\&PROSA"}

\begin{tabular}{|c|l|}
\hline DATA & \multicolumn{1}{|c|}{ OBJETIVOS } \\
\hline $\begin{array}{c}\text { 25/04/2016 } \\
\text { (terça-feira) }\end{array}$ & $\begin{array}{l}\text { 19) Promover contato de brasileiros com os aprendentes; } \\
\text { 20) Praticar o português; } \\
\text { 30) Trocar histórias e experiências de vida e culturas (valorizar a } \\
\text { diferença e reconhecer semelhanças entre os indivíduos e entre as } \\
\text { culturas); } \\
\text { Lo) Possibilitar letramentos de práticas sociais assim como } \\
\text { conhecimentos e aprendizagens diversas. } \\
\text { 5o) Ampliar a rede de amizade e momentos acolhedores; } \\
\text { 6o) Permitir um momento de descontração e divertimento. }\end{array}$ \\
\hline
\end{tabular}

* Observações:

- A intenção é que cada brasileiro possa atender um estudante.

* Dinâmica da atividade:

- Os/as participantes estrangeiros/as serão instruídos/as a passar por quatro salas (marcadas por temas e cores).

- Em cada sala é proposto um tema para nortear a conversa, os temas são: o Brasil (amarelo); habilidades, trabalho, estudo (verde); país de origem (branco); lazer e diversão (azul)

- A ordem do rodízio das salas será escolhida pelo participante estrangeiro, no entanto, ele terá que passar por todas as salas.

- Os participantes brasileiros ficarão fixos nas salas que escolherem.

- O tempo de permanência dos participantes estrangeiros em cada sala será de 10 minutos. Todos serão avisados do término desse tempo por meio de um sino.

- Na última rodada, após o sino tocar, todos os participantes estrangeiros e brasileiros receberão um questionário para avaliar a atividade (10 minutos).

\section{Término:}

Todos serão convidados para o CHÁ, onde desfrutaremos de um lanche, faremos sorteio de livros e ouviremos uma canção que será tocada pelos voluntários do grupo Demonstre Amor Amando. 


\section{Planejamento da Atividade "Despertar profissional”}

\begin{tabular}{|c|l|}
\hline DATA & \multicolumn{1}{c|}{ OBJETIVOS } \\
\hline $\begin{array}{c}\text { 31/05 } \\
\text { (terça-feira) }\end{array}$ & $\begin{array}{l}\text { 19) Despertar habilidades profissionais que os } \\
\text { alunos já possuem e que podem ser direcionadas } \\
\text { para uma recolocação profissional; } \\
\text { 2o) Direcionar os alunos que têm formação } \\
\text { acadêmica para possíveis oportunidade de trabalho } \\
\text { em suas respectivas áreas; }\end{array}$ \\
Local: NEPPE & $\begin{array}{l}\text { 39) Elaborar/ Reelaborar currículos dos alunos; } \\
\text { 49) Fazer um portfólio dos profissionais que } \\
\text { participarão da ação. }\end{array}$ \\
\hline
\end{tabular}

* Observações:

- A intenção é que cada brasileiro possa atender um estrangeiro.

* Dinâmica da atividade:

(19h às 19h40) Palestras:

10 (20 minutos): O despertar de habilidades profissionais

(Estamos procurando algum profissional, de preferência, da área da psicologia.

Alguém conhece?)

20 (20 minutos) Breves noções de direitos trabalhistas (Diego -ACNUR)

\section{(19h40 às 20h40) Elaboração dos currículos e do portfólio}

Elaborar o currículo dos alunos e o portfólio (deve conter uma breve biográfica, o objetivo profissional do aluno e para quais serviços ele está disponível).

\section{Término:}

Todos serão convidados para uma sala grande onde desfrutaremos de um lanche.

Fonte: Elaborados pela autora.

Além do planejamento fiz crachás para as ações para que todos pudessem ser identificados pelo nome e país, organizei uma equipe para recepcionar os participantes e para registrar os nomes, assim como para explicar sobre a atividade e como iria se desenvolver. Durante o desenvolver das atividades, passei em cada sala e solicitei a todos os participantes 
para assinarem, por gentileza e por vontade, o Termo de Consentimento para autorização de fotos e utilização das respostas dos questionários aplicados ao final das atividades, tendo por objetivo coletar dados para este estudo.

Para a atividade Chá\&Prosa, a equipe do Módulo Acolhimento elaborou cartazes com informações dos países dos aprendentes inscritos no curso, com o intuito de ambientalizar o local com conhecimentos e cores sobre os países dos aprendentes. Já para a ação Despertar Profissional, como o tema era profissão, foram elaborados cartazes com as profissões que havia nas turmas do Acolher 1, 2 e 3.

Essas decorações, embora simples, ofereceram ao local um clima mais descontraído, acolhedor e de valorização das culturas e profissões dos aprendentes. Isso foi notável, pois, os participantes das atividades paravam diante dos cartazes e se identificavam:

Figura 14 - Registro Confraternização Chá\&Prosa

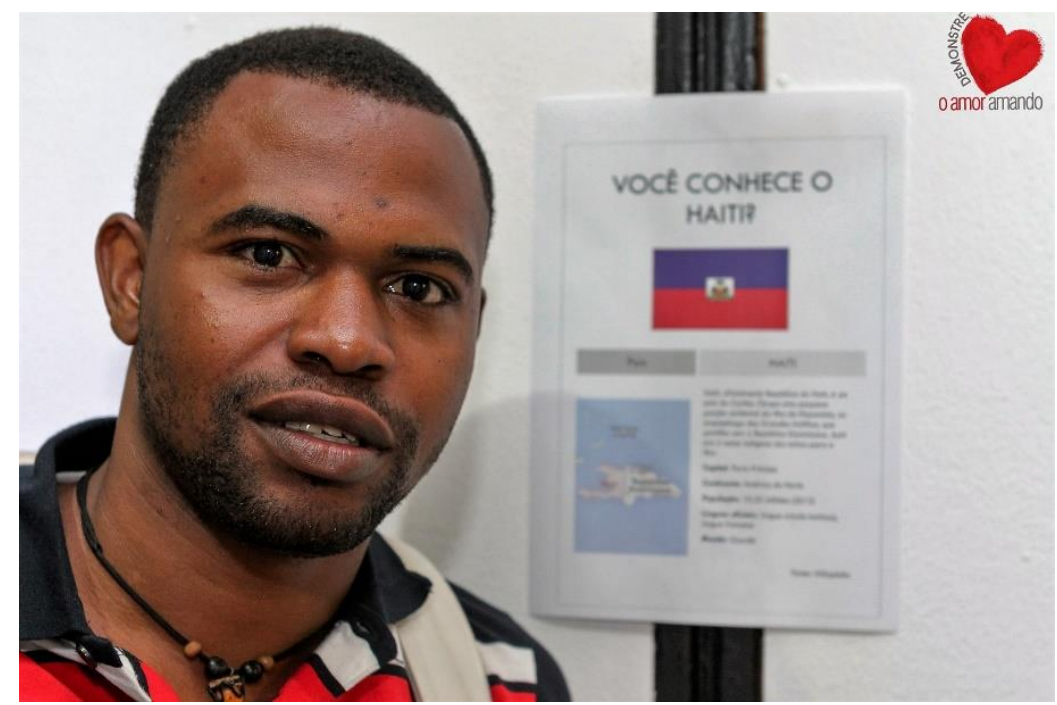

Fonte: Demonstre Amor Amando

Como já informado, as atividades interculturais foram pensadas como extensão dos módulos do material didático do Acolher 1 com objetivo de ampliar os assuntos estudados, permitindo aos aprendentes a oportunidade de vivenciar e praticar as aprendizagens que foram mediadas em sala de aula.

As atividades interculturais foram realizadas ao final de cada módulo, sendo Chá\&Prosa - ao final do módulo Apresentação e o Despertar Profissional - ao término do módulo Trabalho. 


\subsubsection{Análise Chá\&Prosa}

A atividade Chá\&Prosa foi realizada dia 25 de Abril de 2016, das 19h às 20h40, nas dependências do NEPPE. A ação foi divulgada por e-mail e na mídia social do Facebook. Contamos com um total de 27 pessoas que assinaram a lista de presença, mais a equipe de professores e voluntários do Módulo Acolhimento que na época somava em 6 pessoas, dessa maneira, tivemos 33 participantes. De acordo com a lista de presença, tivemos a presença de 9 nacionalidades diferentes, como podemos ver no gráfico a seguir:

Gráfico 3 - Nacionalidades presentes no Chá\&Prosa

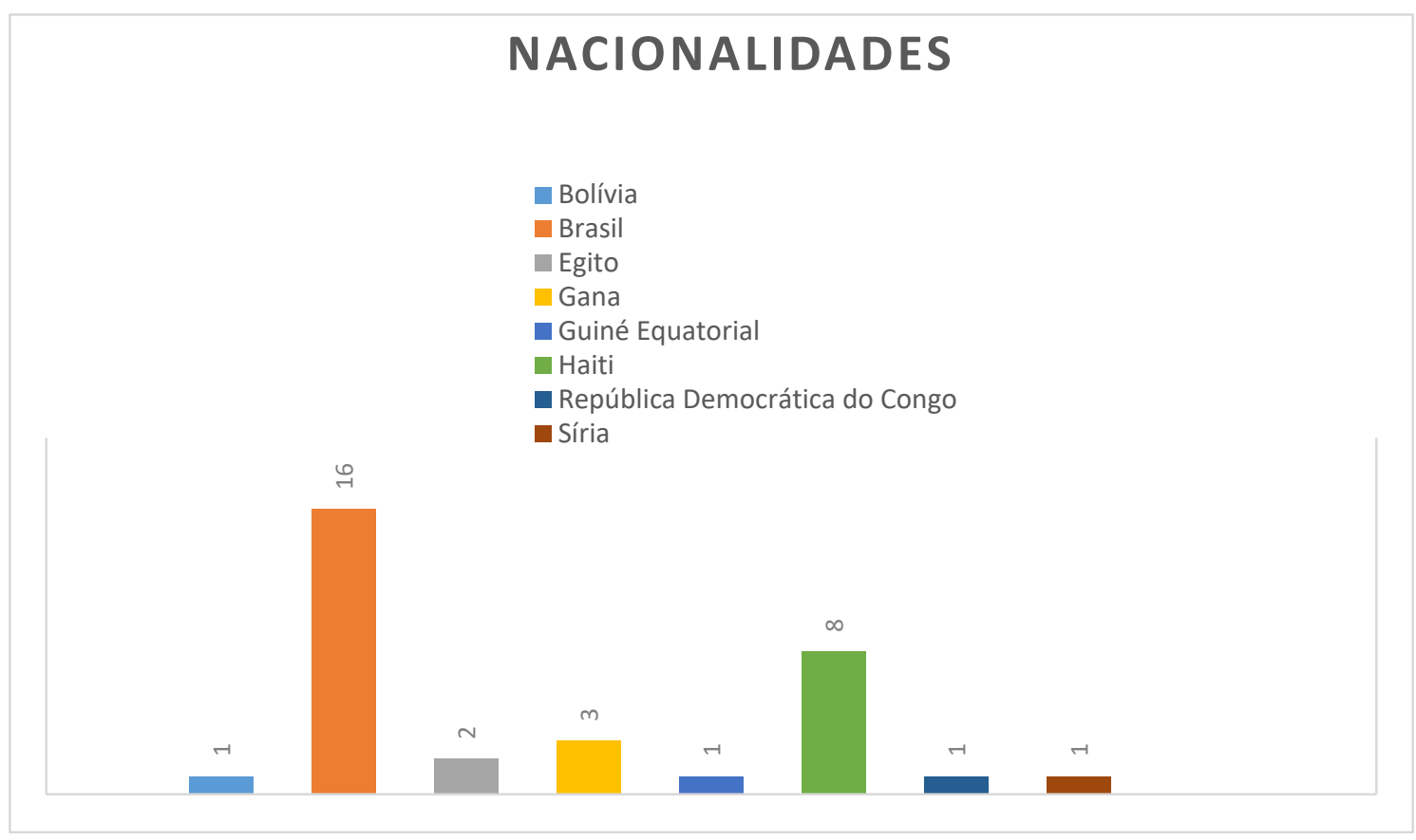

Fonte: Da análise de dados empreendida pela autora.

Essa atividade recebeu o nome Chá\&Prosa, pois um dos objetivos da atividade era de propiciar esse momento de "prosa" entre os estudantes do curso e os brasileiros juntamente com uma confraternização com "chá" e quitutes brasileiros.

Esse momento de "prosa" foi organizado por meio de uma dinâmica que elaborei, tendo em vista os assuntos que trabalhei com a turma do Acolher 1 no módulo Apresentação. No entanto, como a atividade foi aberta a todos do curso, elaborei uma dinâmica que pudesse envolver de maneira ampla todos os participantes, independente de terem visto o módulo. 
A dinâmica se desenvolveu da seguinte maneira: os participantes estrangeiros foram instruídos a passar por quatro salas (marcadas por temas e cores). Em cada sala foi proposto um tema para nortear a conversa, os temas eram: Sobre o Brasil (amarelo); Sobre habilidades, trabalho, estudo (verde); Sobre o país de origem (branco) e Sobre gostos, lazer e diversão (azul).

A ordem do rodízio das salas era escolhida pelos aprendentes, no entanto, todos deveriam passar por todas as salas. Os participantes brasileiros ficaram fixos nas salas que haviam escolhido no início da dinâmica, não podiam se movimentar, pois senão poderiam ocorrer tumultos e também para deixar a escolha para os estudantes.

O tempo de permanência em cada sala era de 10 minutos. Todos eram avisados do término desse tempo, por meio de um sino que soava no corredor que ligava as salas. Na quarta, última rodada, antes do sino tocar, todos os participantes (aprendentes e brasileiros) receberam um questionário para avaliar a atividade, sendo atribuído mais um tempo para que pudessem responder ao questionário. Após responderem ao questionário, todos foram convidados para uma sala maior, onde servimos um chá e desfrutamos de um lanche.

Nesse momento da confraternização, uma apresentação musical foi feita pelo grupo de jovens e adultos Demonstre Amor Amando. Todos ouviram a canção atentamente e logo após o grupo ter se apresentado, um dos nossos aprendentes haitiano pediu a permissão para cantar uma música na língua crioulo (créole).

Esse momento foi de uma riqueza intercultural, pois a canção entoada era uma música gospel que muitos dos participantes presentes sabiam em português, assim a música foi cantada em crioulo pelos haitianos e em português pelos brasileiros.

Esse pertencimento despertado por uma música em comum, na minha percepção e no que pude observar pelos rostos dos participantes, pelos registros feitos nesse momento da confraternização, possibilitou uma atmosfera acolhedora entre todos e de identificações, pois independentemente das nacionalidades, culturas, naquele momento todos estavam ali dividindo uma música, sorrisos, compartilhando histórias, línguas, risadas e criando novos contatos. A seguir apresento alguns dos registros feitos que refletem um pouco da dimensão desse momento da interação entre os participantes: 
Figura 15 - Registro Confraternização Chá\&Prosa

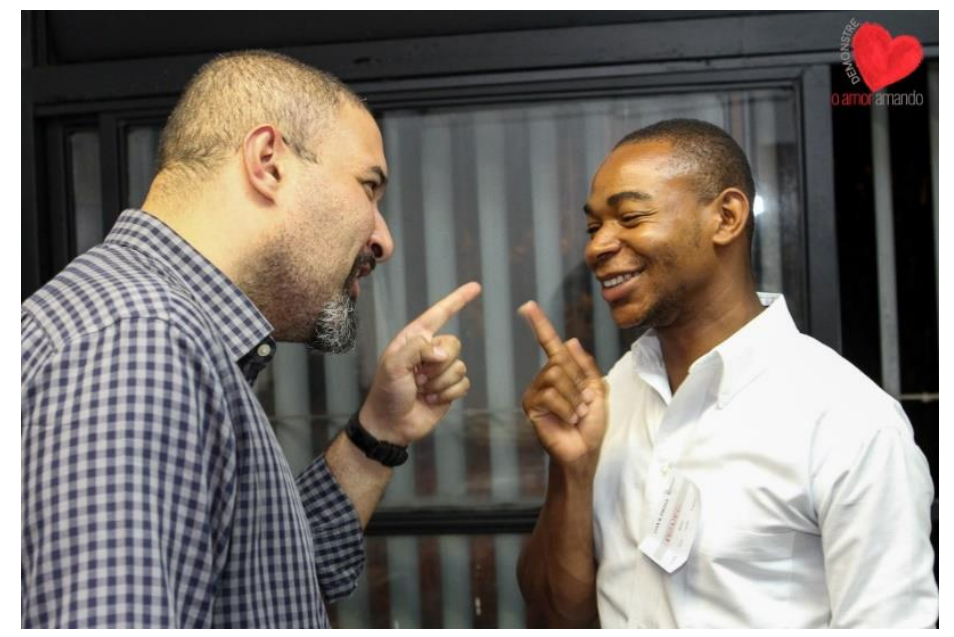

Fonte: Demonstre Amor Amando.

Figura 16 - Registro Confraternização Chá\&Prosa

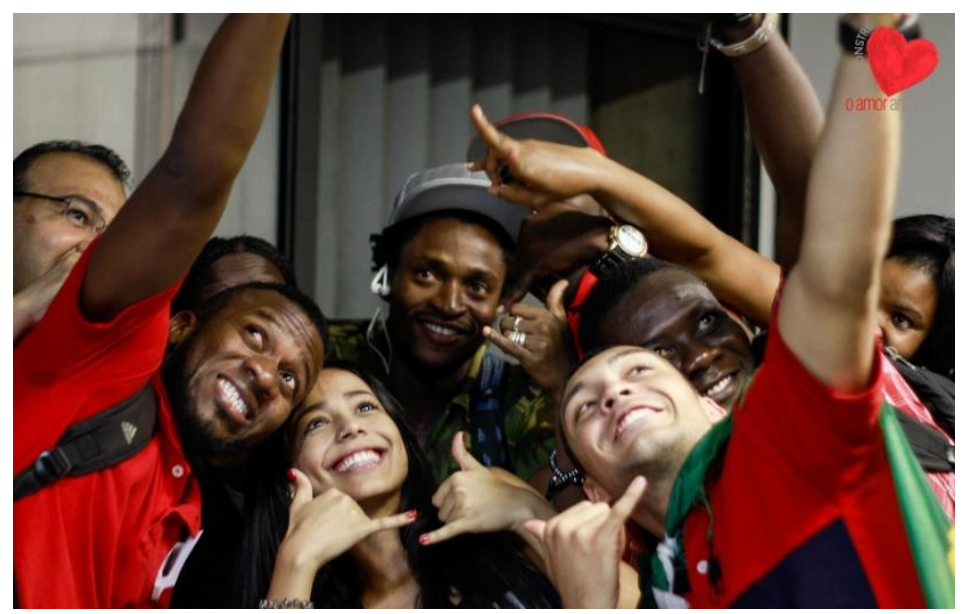

Fonte: Demonstre Amor Amando.

Figura 17 - Registro Confraternização Chá\&Prosa

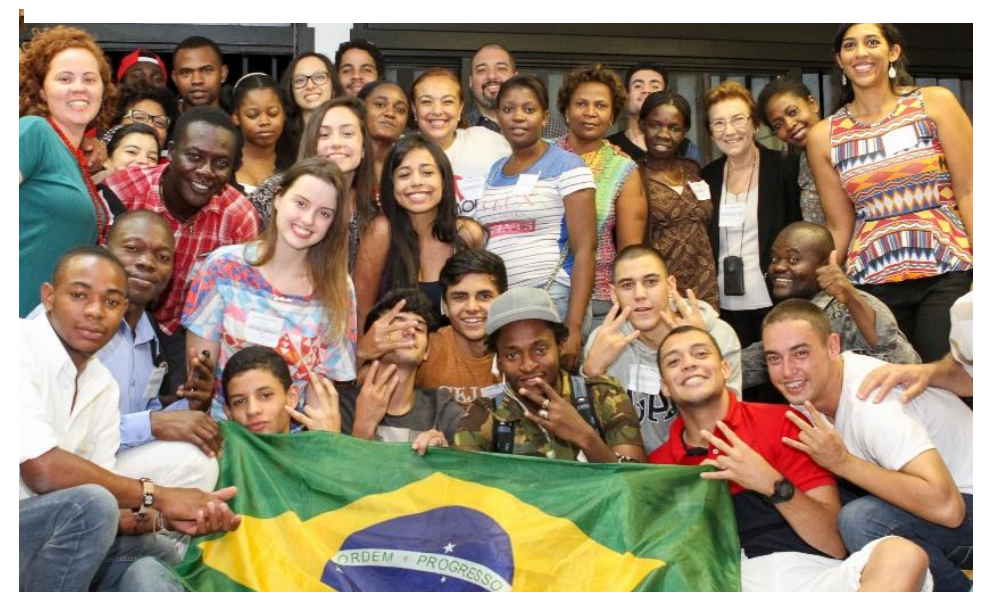

Fonte: Demonstre Amor Amando. 
Enquanto os registros das fotos possibilitaram observar de forma mais visual o contato e a proximidade entre os participantes, as respostas dos questionários aplicados ao final da atividade permitiram investigar e analisar, de maneira mais aprofundada, as percepções dos participantes não brasileiros sobre o processo de aprendizagem e aquisição de português, sobre os letramentos mediados durante as atividades, sobre as reflexões e efeitos de interculturalidade e sobre o sentimento de acolhida e interação com os outros.

O questionário, como já informado, foi aplicado ao final da atividade a todos os participantes, entretanto, nem todos responderam ao questionário, pois alguns tiveram que sair mais cedo da atividade.

No Chá\&Prosa tivemos um total de 18 estrangeiros e 15 brasileiros que responderam ao questionário. Ressalto que neste estudo analiso as respostas somente dos participantes estrangeiros, com a finalidade de investigar como essa atividade permitiu desenvolver o aprendizagem e aquisição da língua, letramentos e interculturalidades.

Como já mencionado, os questionários foram elaborados em três línguas: português, francês e inglês a fim de que todos os participantes pudessem ter uma melhor compreensão sobre as questões. O objetivo futuramente é ampliar ainda mais essas traduções para outras línguas.

O questionário consistiu em 3 questões de múltipla escolha e 1 aberta. As questões de múltipla escolha tinham o propósito de verificar de forma mais direta a opinião sobre o que acharam da atividade, quais foram as dificuldades e qual o tema/assunto que mais gostaram de falar ou ouvir. A questão aberta foi elaborada com o intuito de investigar o que os participantes acharam e aprenderam com a atividade.

Para esse estudo, foi a questão aberta que me trouxe dados para análise, no entanto, também apresento os resultados das questões de múltipla escolha, para ter uma visão e compreensão da avaliação feita pelos aprendentes dessa atividade.

Apresento a seguir os resultados das respostas referentes às questões de múltipla escolha: 
Quadro 11- Respostas das questões de múltipla escolha - Chá\&Prosa

\begin{tabular}{|l|l|}
\hline Participantes & $\begin{array}{l}\text { 1. Marque o você achou da } \\
\text { atividade } C H A ́ \text { \& PROSA } \\
\text { realizada hoje? }\end{array}$ \\
\hline 2 & muito ruim \\
\hline 0 & Ruim \\
\hline 0 & Razoável \\
\hline 1 & boa \\
\hline 15 & muito boa \\
\hline
\end{tabular}

\begin{tabular}{|l|l|}
\hline Participantes & $\begin{array}{l}\text { 2. Quais foram as maiores } \\
\text { dificuldades? (Você pode } \\
\text { assinalar quantos quiser) }\end{array}$ \\
\hline 10 & não tive dificuldades \\
\hline 4 & falar e entender em português \\
\hline 4 & interagir com as pessoas \\
\hline 5 & falar sobre os temas \\
\hline
\end{tabular}

\begin{tabular}{|l|l|}
\hline Participantes & $\begin{array}{l}\text { 3. Qual o tema você mais gostou } \\
\text { de falar? }\end{array}$ \\
\hline 7 & sobre o país de origem \\
\hline 11 & $\begin{array}{l}\text { sobre habilidades, trabalho e } \\
\text { estudos }\end{array}$ \\
\hline 4 & sobre lazer e diversão \\
\hline 6 & sobre o Brasil \\
\hline
\end{tabular}

Fonte: Da análise de dados empreendida pela autora

Por meio dos resultados da primeira pergunta, pode-se sugerir que a atividade agradou a maior parte dos aprendentes, sendo considerada muito boa por 15 participantes, no entanto, 2 participantes consideraram a atividade muito ruim. Sobre esses dados não tenho como discorrer, pois foram questões fechadas, dessa maneira, não houve explicações mais pontuais sobre o motivo de não terem gostado da atividade. De acordo com o resultado, 10 participantes não tiveram nenhuma dificuldade e 9 apresentaram dificuldades. Os dados sugerem que a maior parte dos participantes está conseguindo se movimentar na língua.

Considero esse reconhecimento das dificuldades importante, pois possibilita ao aprendente perceber em que ponto ele precisa melhorar e também nos indica onde podemos focar/desenvolver mais o ensino-aprendizagem a fim de diminuir as dificuldades e possibilitar uma melhor aprendizagem e aquisição da língua-alvo. 
A terceira questão nos permitiu verificar qual o assunto os aprendentes têm mais interesse em falar e ouvir e, pelo resultado, observamos que falar sobre habilidades, trabalho e estudo foi o tema mais escolhido.

Esse resultado nos permite compreender e sugerir que o assunto referente a trabalho é tido como o principal, uma vez que, para muitos dos aprendentes que estavam participando da dinâmica, essa ainda é a necessidade emergente: a de conseguir um trabalho e também a de querer e almejar a continuar os estudos. Essa opção deixa ainda mais evidente a necessidade de as pessoas de buscarem melhores condições de vida ou mesmo a premente necessidade de sobrevivência.

Além disso, notei durante as atividades, e também em sala de aula, que falar sobre a profissão, sobre as habilidades que os aprendentes possuem, colabora para recuperar a autoestima dessas pessoas que, muitas vezes, percebo que se encontra baixa.

Essa baixa autoestima dos aprendentes está relacionada a vários fatores, tais como não terem mais o status social e profissional como tinham no país de origem, por não conseguirem se comunicar e expressar em consequência da barreira linguística, por sofrerem, muitas vezes, discriminação e racismo, por serem refugiados ou mesmo pela cor da pele. Percebo que esses fatores influenciam diretamente no ensino-aprendizagem de uma língua e na integração desses indivíduos na sociedade de acolhimento.

Dessa forma, oportunizar esse momento para que essas pessoas possam compartilhar de experiências profissionais, de habilidades que têm e de sonhos de estudos e formação possibilita resgatar a identidade profissional desses indivíduos e reconstruir sonhos profissionais nessa nova trajetória de vida em outro país.

As questões de múltipla escolha possibilitaram verificar, de forma mais sistemática, a opinião desses aprendentes sobre a atividade e os assuntos que gostaram de falar. A questão aberta foi a que me gerou dados para investigar e analisar como essa atividade buscou atender aos objetivos propostos para o Acolher 1 de ensino-aprendizagem de português. A questão se estruturou da seguinte maneira: "escreva o que você achou e aprendeu com a atividade de hoje".

Durante a leitura das respostas da questão aberta, fui identificando evidências ligadas à aprendizagem e aquisição do português; letramentos, efeitos e reflexões interculturais, sentimento de acolhimento e percepção sobre a atividade.

De acordo com as evidências, elaborei quadros categorizando as respostas, sendo: $1^{\text {a }}$ Categoria: Aprendizagem e aquisição do português; $2^{\mathrm{a}}$ Categoria: Reconhecimento de letramento e aprendizagens; $3^{\mathrm{a}}$ Categoria: Efeitos e reflexões interculturais; $4^{\mathrm{a}}$ Categoria: Sentimento de acolhimento e $5^{\text {a }}$ Categoria: Percepção da atividade. Destaco que mantive as 
respostas dos aprendentes na língua em que eles se expressaram a fim de manter a fidelidade e densidade das respostas.

Em relação à $1^{\text {a }}$ Categoria, apresento o quadro a seguir:

Quadro 12 - $1^{\text {a }}$ Categoria: Aprendizagem e aquisição de português

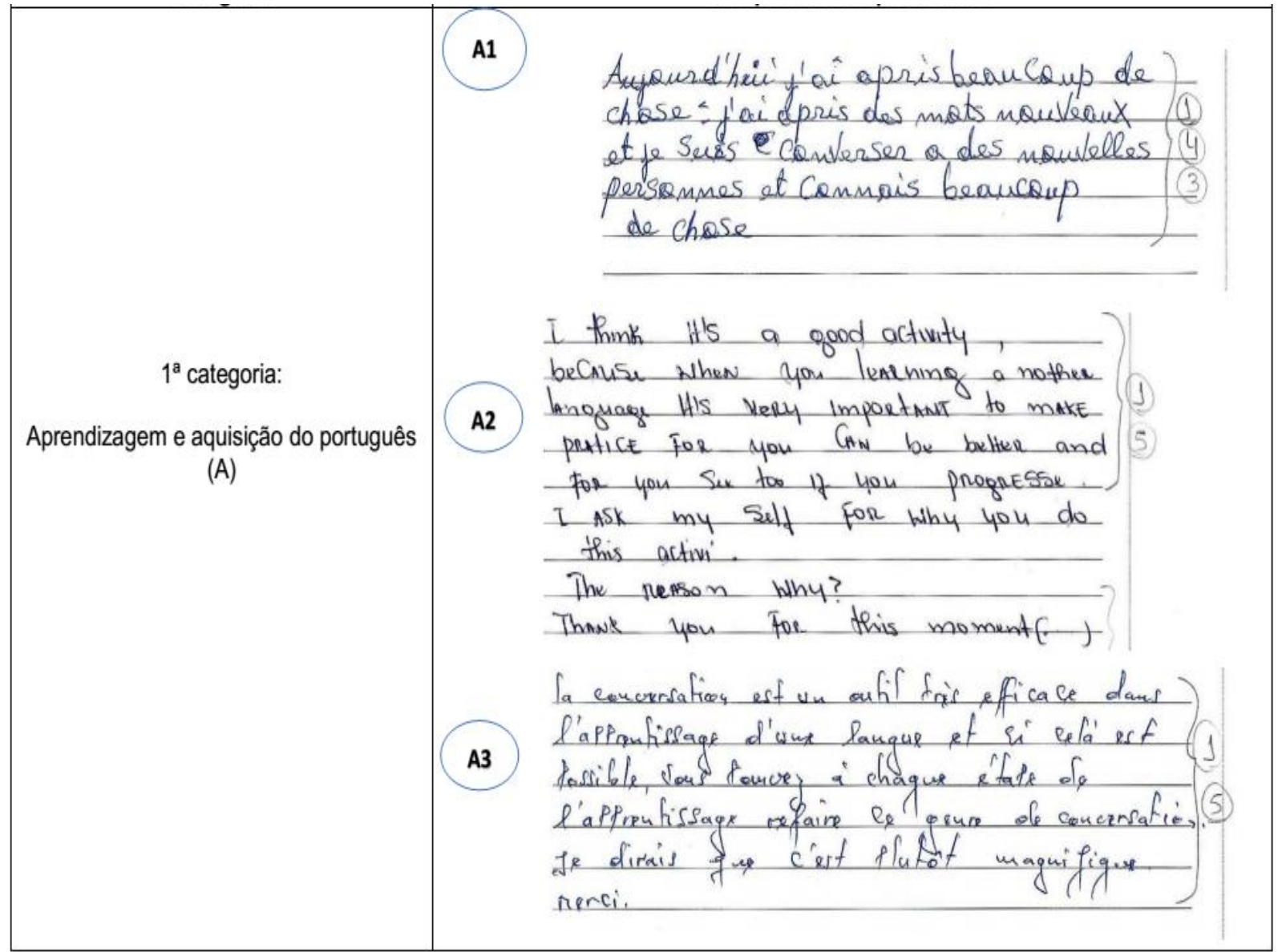

Fonte: Da análise de dados empreendida pela autora.

Nessa categoria foi que identifiquei mais respostas, no total foram 6 respostas que expressaram com nitidez sobre o fato da atividade ter contribuído para a aprendizagem e aquisição da língua-alvo, no entanto, para compor o quadro selecionei três respostas.

Como se pode observar, as três respostas confirmam que a atividade foi importante para praticar a língua-alvo (A2) “When you learning a mother language it's very important to make pratice”, para aprender novas palavras (A1) " $j$ 'ai apris de mots nouveaux" e para avançar na aprendizagem da língua (A3) "la conversation est un outif três efficace dans l'apprentissage d'une langue". 
Essas percepções e reconhecimento, dos próprios aprendentes de que momentos para praticar a língua estudada são necessários, evidencia que esses aprendentes já têm um conhecimento e estratégias para aprendizagem de aquisição de uma nova língua. Isso contribui para o nosso ensino, uma vez que tendo essa consciência eles procurem meios para poder praticar a língua.

Porém, pelas minhas observações em sala de aula, por meio de conversas informais com os aprendentes, percebo que não são todos que têm esse conhecimento e/ou mesmo a oportunidade de praticar a língua. Dessa forma, essa atividade contribui para oportunizar esse momento de experienciar o português e ratificar para alguns que, efetivamente, a prática da língua-alvo é de extrema importância para aquisição dessa.

A $2^{\mathrm{a}}$ Categoria não esteve muito presente nas respostas analisadas, apresento no quadro a seguir as duas respostas identificadas a respeito de letramentos:

Quadro $13-2^{\text {a }}$ Categoria: Reconhecimento de letramento e aprendizagens

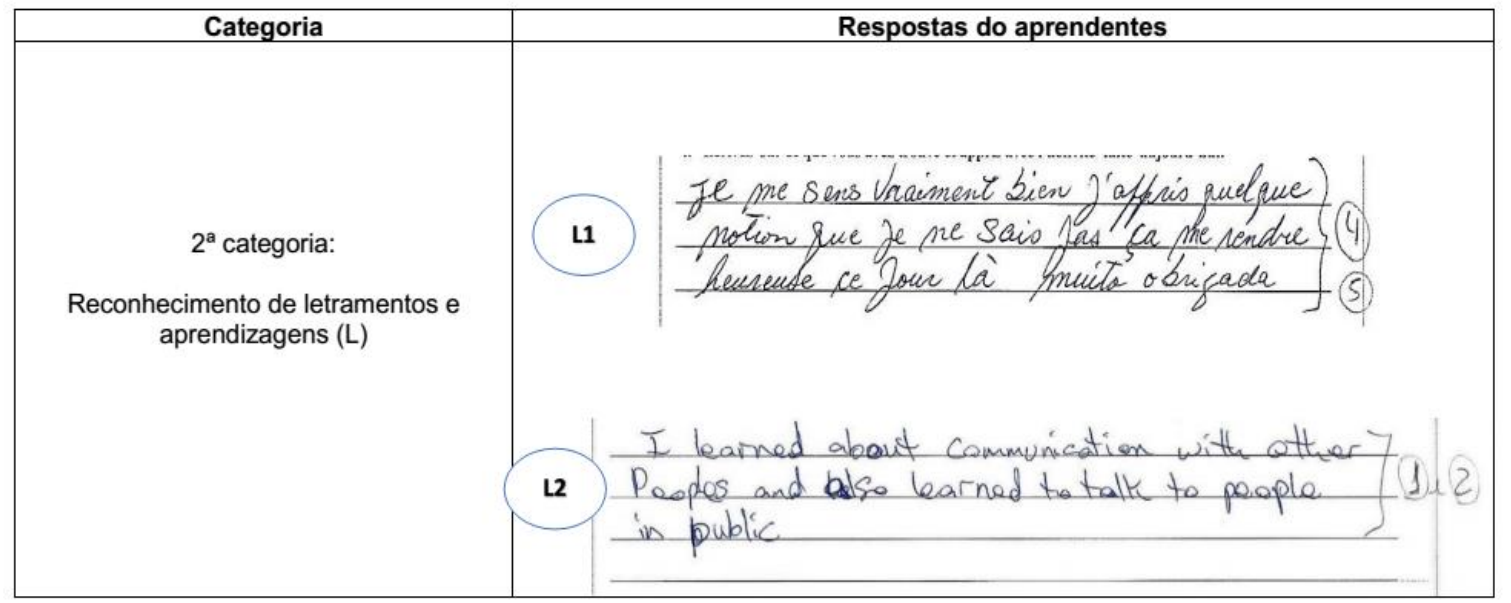

Fonte: Da análise de dados empreendida pela autora.

A resposta L1 traz uma percepção mais generalizada - "j'appris quelque notion que je ne sais pas ça me rendre heureuse ce jour là" - não aponta exatamente algum tipo de letramento, mas apenas uma aprendizagem de algo que o aprendente sabia mas que, no entanto, não foi explicitado. A resposta L2 marca letramentos tais como se comunicar com outras pessoas e conversar em público: "I learned about comunication with other peoples and also learned to talk to people in public". Diante dos dados, percebo que essa categoria não foi bem desenvolvida nessa atividade, e isso se deveu ao próprio objetivo da atividade, que consistia em 
possibilitar momentos mais focados para experienciar a língua portuguesa por meio de conversação com brasileiros. Evidentemente que esses momentos também poderiam propiciar letramentos, no entanto, não foram perceptíveis aos aprendentes.

Em relação à $3^{a}$ Categoria, observei evidências em 3 respostas:

Quadro 14 - $3^{\text {a }}$ Categoria: Efeitos e reflexões interculturais

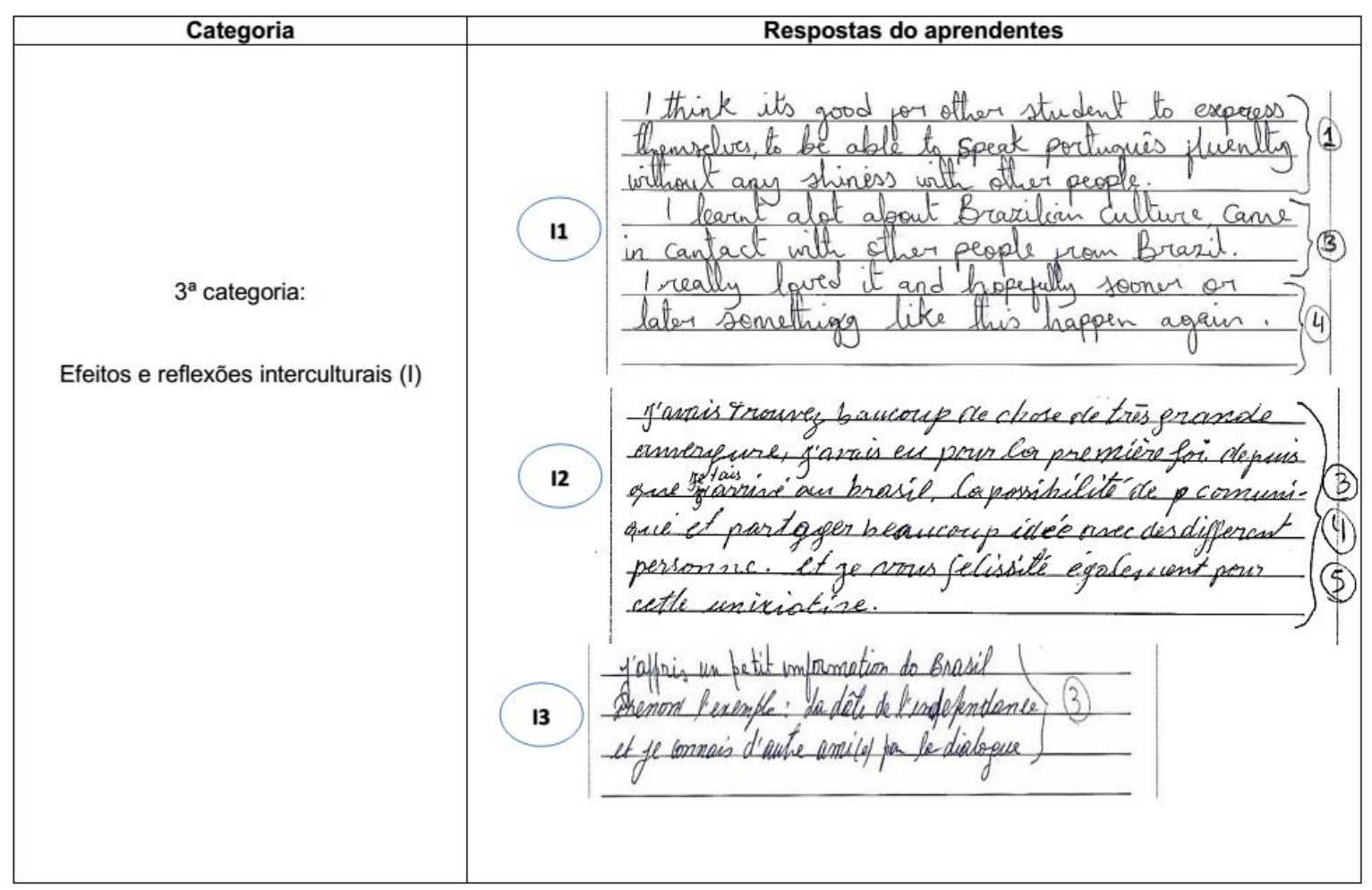

Fonte: Da análise de dados empreendida pela autora.

As respostas I1 e I2 expressam a satisfação dos aprendentes em terem aprendido informações sobre o Brasil e a cultura brasileira, tais com a data de independência do Brasil (I3) "j'appris un petit information du Brasil, l'exemple: la date de independance" e por terem tido o contato com pessoas do Brasil (I1) "I learnt a lot about Brazilian culture came in contact with other people from Brazil".

A resposta 2 apresenta um breve relato de um aprendente que se mostra feliz pela oportunidade de ter tido, pela primeira vez, desde que chegou no Brasil, a oportunidade de comunicar e dividir muitas ideias diferentes com as pessoas: " $j$ 'avais eu pour la premíere foi depuis que j'ai arrivé au brasil la possibilite de comunique et partager beaucoup ideé avec 
differente personne". Esse sentido de dividir ideias, expressa na resposta I2, confirma momentos interculturais, isto é, esse estudante pôde, por meio de uma conversa, promover trocas culturais, transitar entre culturas (a sua e a do outro) percebendo diferenças e semelhanças.

Ao que concerne à $4^{a}$ Categoria: Sentimento de acolhimento, foram identificadas 5 respostas:

Quadro 15-4 Categoria: Sentimento de acolhimento

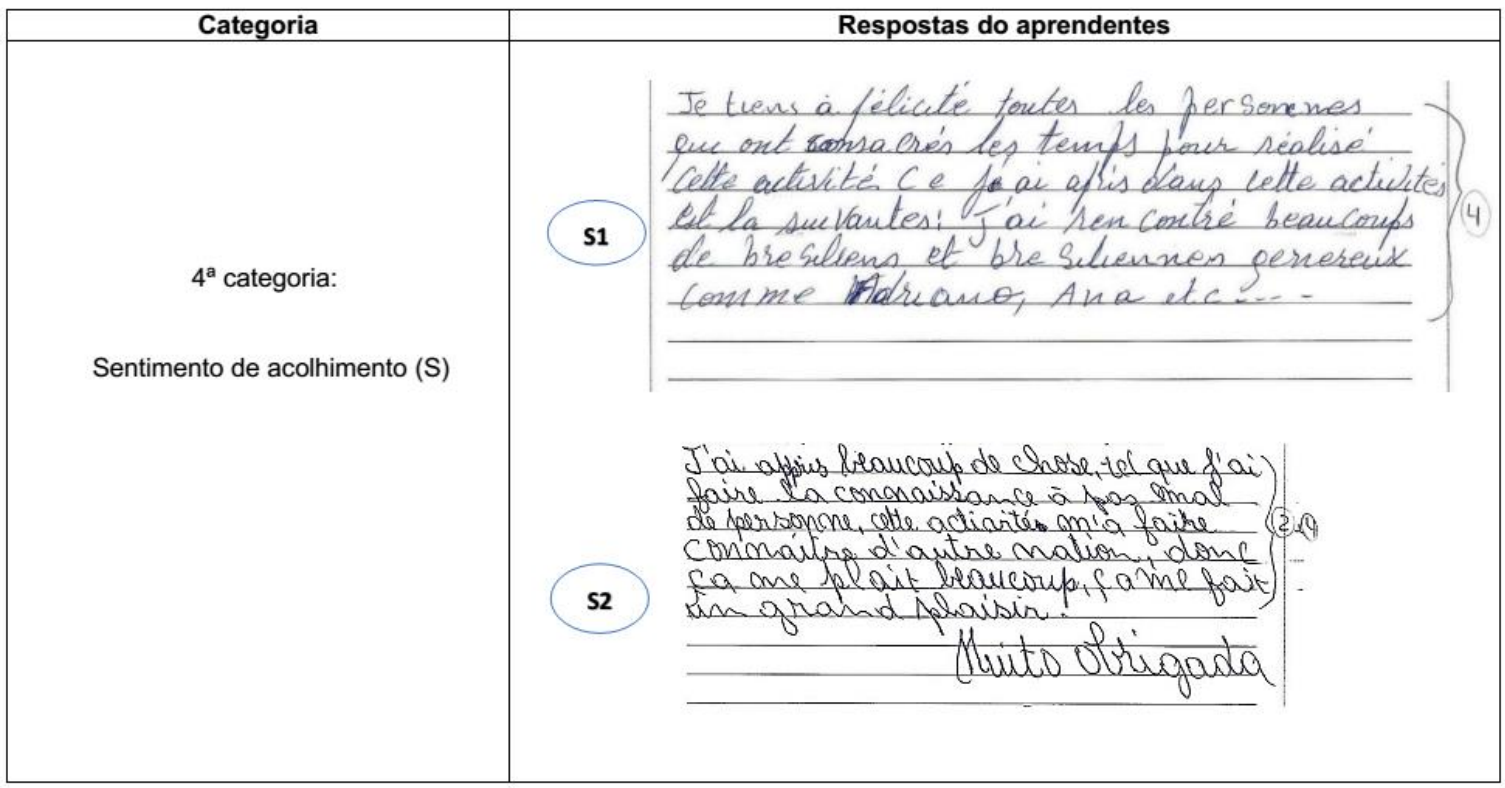

Fonte: Da análise de dados empreendida pela autora.

A primeira resposta S1 retrata esse sentimento de acolhimento em forma de agradecimento "Je tiens a felicite toutes les personnes que ont consacrés les temps pour realise cette activité" (S1) e também pelo adjetivo "genereux" atribuído aos brasileiros citados na resposta.

Na resposta S2, o sentimento de acolhimento não fica tão evidente, mas faço uma leitura sobre o fato da atividade ter proporcionado, para esse aprendente, o conhecimento de outras nações o que resultou, conforme ele se expressa "ça me fait um grand plaisir", segundo analiso nessa sua fala, em um sentimento de acolhimento, pois esse aprendente pôde compartilhar acolhidas com outras nacionalidades, o que permitiu que ele afirmasse: “j'ai appris beaucoup de chose" (S1). 
Diante da análise dos dados gerados pelas respostas dos aprendentes, observei que essa atividade atendeu, de alguma maneira, aos objetivos do ensino propostos no Acolher 1, no entanto, com níveis diferenciados.

A Categoria que mais pôde ser identificada nos dados foi a $1^{\text {a }}$ Categoria, o que vem ao encontro de um dos objetivos propostos na atividade: praticar português. A finalidade de desenvolver letramentos e interculturalidades precisa ser mais bem repensado, pois avalio, pelas minhas observações, que mesmo que eles tenham sido alcançados, não ficaram, contudo, tão evidentes aos aprendentes.

Para concluir a análise dessa atividade, apresento uma $5^{\text {a }}$ Categoria que evidencia a opinião/percepção dos aprendentes sobre a atividade Chá\& Prosa:

Quadro 16 - 5a Categoria: Percepções da atividade

\begin{tabular}{|c|c|}
\hline Categoria & Respostas do aprendentes \\
\hline Percepções da atividade (P) & 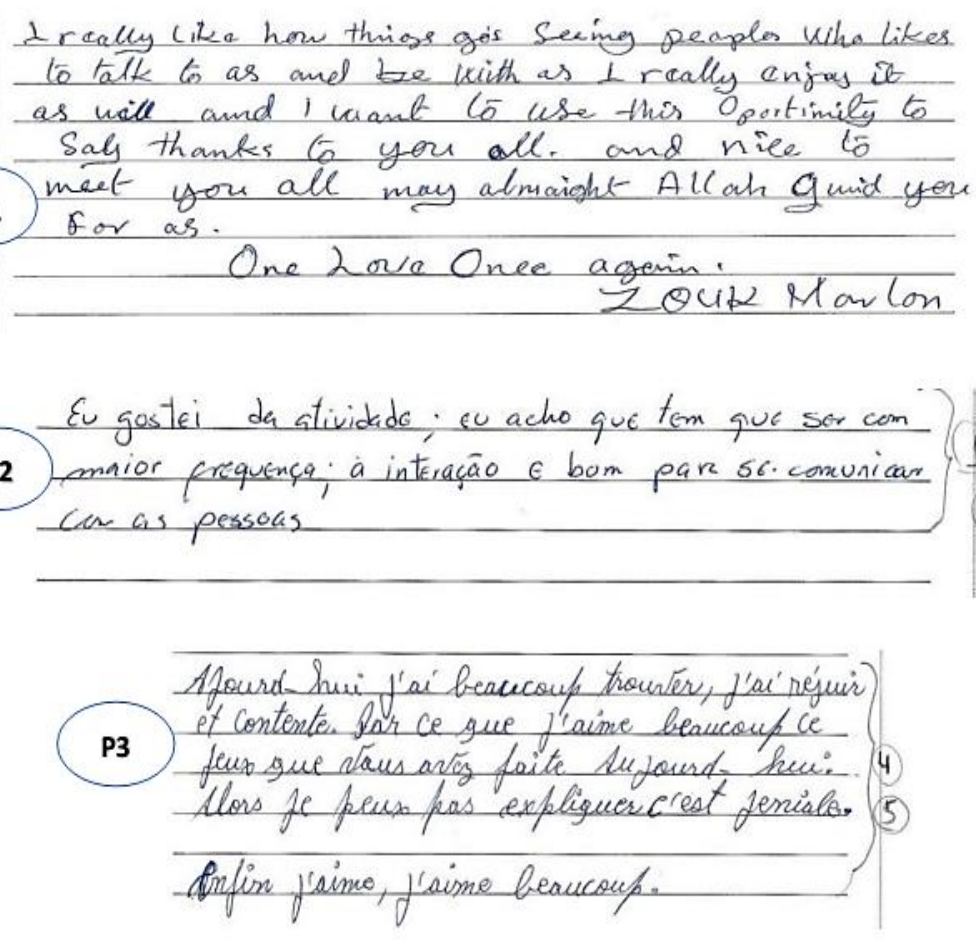 \\
\hline
\end{tabular}

Fonte: Da análise de dados empreendida pela autora.

A avaliação dos aprendentes sobre a atividade mostrou-se positiva, a maioria das respostas apresenta um agradecimento por terem vivido o momento, conhecido brasileiros, aprendido novos conhecimentos e compartilhado desse momento de Chá e prosa. 
As três respostas selecionadas expressam bem a satisfação e o agradecimento desses aprendentes por termos realizado a atividade: P1 "say thanks to you all and nice to meet you all”; P2 "Eu gostei da atividade, eu acho que tem que ser com maior frequença”; P3 “Alors je peux pas expliquer c'est geniale”. Além disso, pelos dados - P2 “j'aime beaucoup ce jeux que vous avez faite aujourd 'hui"'- concluiu-se que também tivemos sucesso no jogo proposto entre salas e temas, pois ele dinamizou o nosso encontro e colaborou para que todos pudessem se conhecer de maneira mais organizada e divertida.

Passo para análise da atividade intercultural do Despertar Profissional.

\subsubsection{Análise Despertar Profissional}

A atividade Despertar Profissional foi realizada dia 31 de maio de 2016, das $19 \mathrm{~h}$ às 20h40, nas dependências do NEPPE. A ação, da mesma forma que a anterior, foi divulgada por e-mail e na mídia social do Facebook. Convidamos as pessoas que haviam participado da atividade Chá\&Prosa, assim como outros brasileiros. Contamos com um total de 54 pessoas que assinaram a lista de presença, sendo 30 participantes estrangeiros e 24 participantes brasileiros. De acordo com a lista de presença, tivemos a presença de 10 nacionalidades diferentes, como pode ser observado no gráfico a seguir:

Gráfico 4 - Nacionalidades presentes no Despertar Profissional

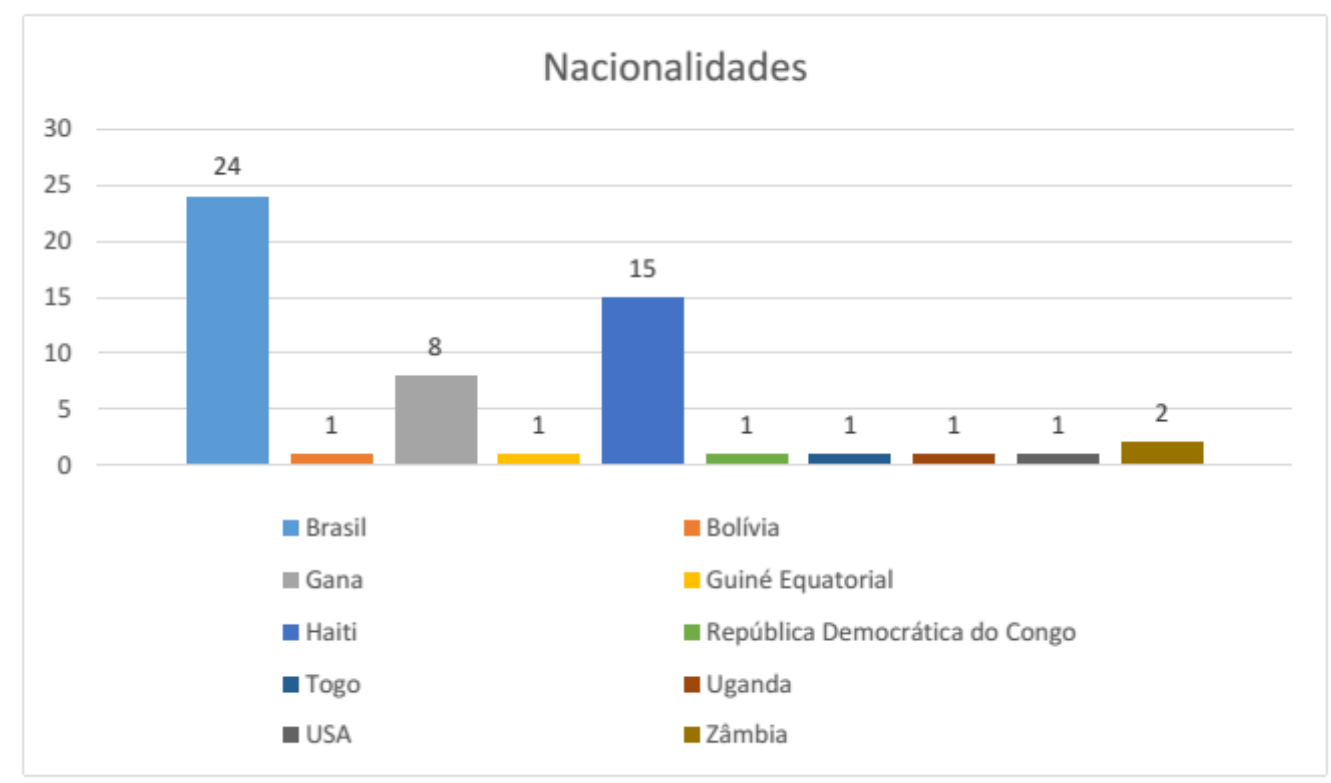

Fonte: Da análise de dados empreendida pela autora. 
Essa atividade recebeu o nome de Despertar Profissional, pois a ação teve por objetivos específicos: apresentar algumas noções sobre direitos e deveres trabalhistas na sociedade brasileira, incitar/despertar os estudantes estrangeiros a pensarem e refletirem sobre as habilidades profissionais que eles possuíam e que poderiam ser direcionadas para uma recolocação profissional no Brasil; elaborar ou mesmo reelaborar o curriculum e um portfólio profissional apresentando essas habilidades profissionais, a fim de direcionar/orientar os aprendentes que tinham formação acadêmica para possíveis oportunidades de trabalho em suas respectivas áreas. Os aprendentes que não tinham formação acadêmica, tentamos investigar suas habilidades e experiências profissionais para orientá-los para trabalhos que não exigissem formação acadêmica ou mesmo auxiliá-los com indicação de lugares, universidades, centros educacionais em que pudessem dar continuidade aos estudos.

Além desses objetivos específicos, retomo que os objetivos que conduziram todas as atividades realizadas no Módulo Acolhimento foram os de apresentar aos aprendentes a importância de terem momentos para praticar português, para estabelecer contatos e trocas culturais com brasileiros, para desenvolver letramentos de práticas sociais e para propiciar momentos de acolhimento e diversão.

Essa atividade foi realizada logo após a conclusão do módulo Trabalho, desenvolvida na turma do Acolher 1. Esse módulo pretendeu apresentar vocabulários pertencentes à área de trabalho e profissões, conhecimentos sobre as leis trabalhistas, letramentos sobre práticas sociais relacionadas ao cotidiano do trabalho, como ler e procurar um anúncio e classificado de emprego, enviar um e-mail, elaborar um curriculum e portfólio profissional e se preparar para uma entrevista de emprego.

Esses conhecimentos foram desenvolvidos e experienciados durante as aulas do Acolher 1 e retomados durante a atividade Despertar Profissional. Dessa forma, os aprendentes dessa turma já estavam um pouco mais preparados para a dinâmica da atividade, pois já haviam tido contato com os assuntos e com os gêneros textuais apresentados.

No entanto, tendo em vista que a atividade foi elaborada para atender a todos os aprendentes do curso Módulo Acolhimento, tentamos elaborá-la e organizá-la de modo que não desfavorecesse ninguém, assim retomamos a ação de elaboração de curriculum e portfólio.

O Despertar Profissional iniciou-se com uma palestra sobre os direitos trabalhista ministrada pelo convidado Diego Nardi, que é assistente de proteção do ACNUR. Destaco que a palestra teve tradução simultânea em francês, por Paula Coury, e em inglês, por Julia Rovery, funcionária e voluntária do IMDH, respectivamente. O objetivo dessa palestra foi de mediar informações de direitos e deveres no âmbito do trabalho. 
A palestra que estava com tempo determinado para acontecer em 20 minutos, se estendeu para 50 minutos, pois muitas dúvidas e questões foram colocadas pelos aprendentes. A sala onde ocorreu a palestra ficou pequena para a quantidade de participantes, como se pode conferir pelo registro:

Figura 18 - Palestra sobre direitos trabalhistas

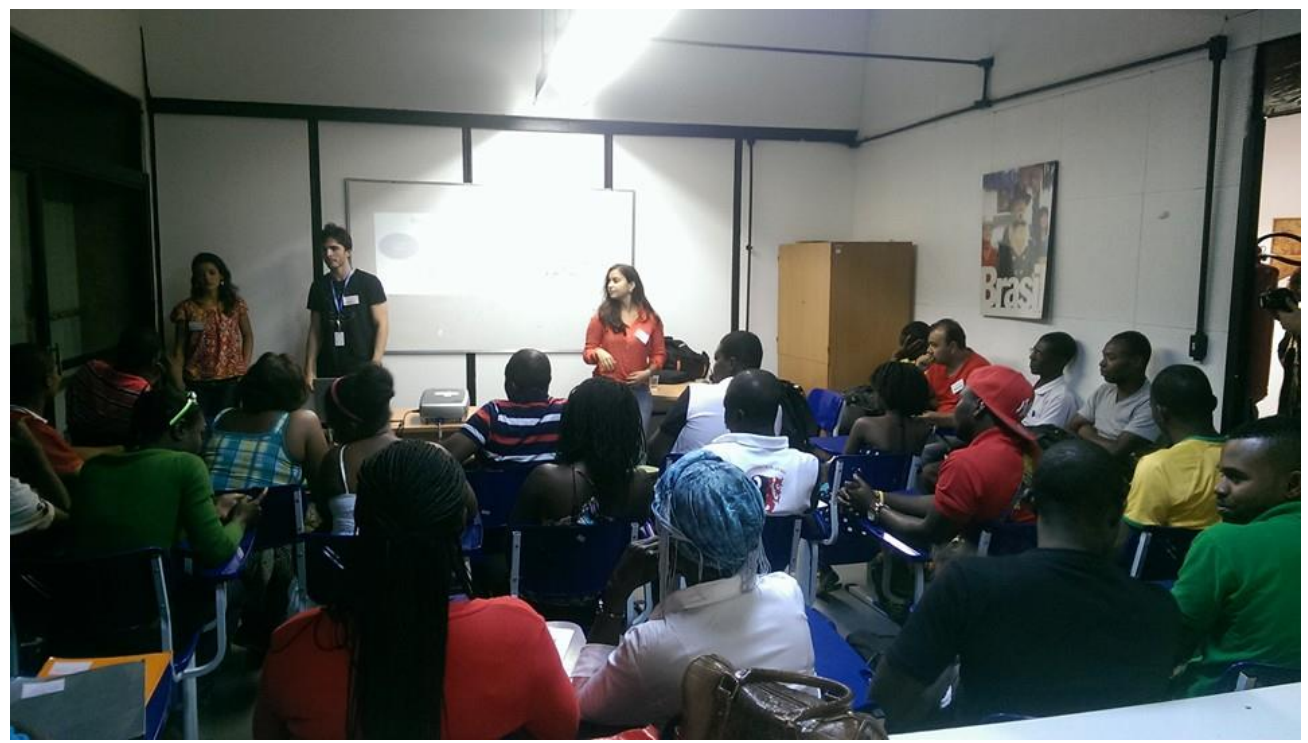

Fonte: Registro da autora.

Após sanar algumas dúvidas, pedimos para que fosse encerrada a palestra para prosseguirmos nossa programação e ação. $\mathrm{O}$ assistente se predispôs a continuar a palestra ou mesmo oferecer um atendimento futuramente para os participantes que se interessassem em tirar outras dúvidas.

Essa palestra e as dúvidas que surgiram, mostraram-me a premente necessidade de oferecer a essas pessoas mais informações, conhecimentos e letramentos sobre leis, sobre práticas socioculturais que permeiam diversas áreas, tais como a do trabalho, da saúde, da educação, da cultura, dentre outras.

Esses conhecimentos e informações, além de colaborarem para que haja uma melhor inserção na sociedade brasileira, também colaboram para um empoderamento desses indivíduos, uma vez que, obtendo conhecimentos sobre direitos e deveres, letramentos de como funcionam as leis e sobre onde eles podem recorrer, contribui para que eles possam se proteger de enganações e atitudes de má fé de outrem. Além disso, ter esses conhecimentos auxilia na inserção desses indivíduos na sociedade brasileira. 
Após a palestra, foi servido um lanche para todos os participantes e, em seguida, direcionamos os aprendentes para as salas, onde se encontravam brasileiros para auxiliar na elaboração do portfólio e do curriculum. Cada brasileiro atendeu um ou dois aprendentes.

Os participantes brasileiros foram instruídos, pela equipe de recepção que estava na porta de entrada da atividade, como iriam proceder com a elaboração de curriculum e do portfólio.

Nessas instruções foi destacado que o objetivo era ajudar a produzir esses gêneros textuais, investigando e despertando no aprendente uma reflexão sobre as habilidades que eles tinham e que poderiam aproveitar para conseguirem um trabalho no Brasil.

Essa ação demorou uns 50 minutos e foi perceptível, pelas observações que realizei ao percorrer as salas, que todos os participantes estavam engajados e concentrados na elaboração dos gêneros. A seguir, apresento os registros que retratam um pouco desses momentos:

Figura 19 - Registro Elaboração curriculum e Portfólio - Desperta Profissional
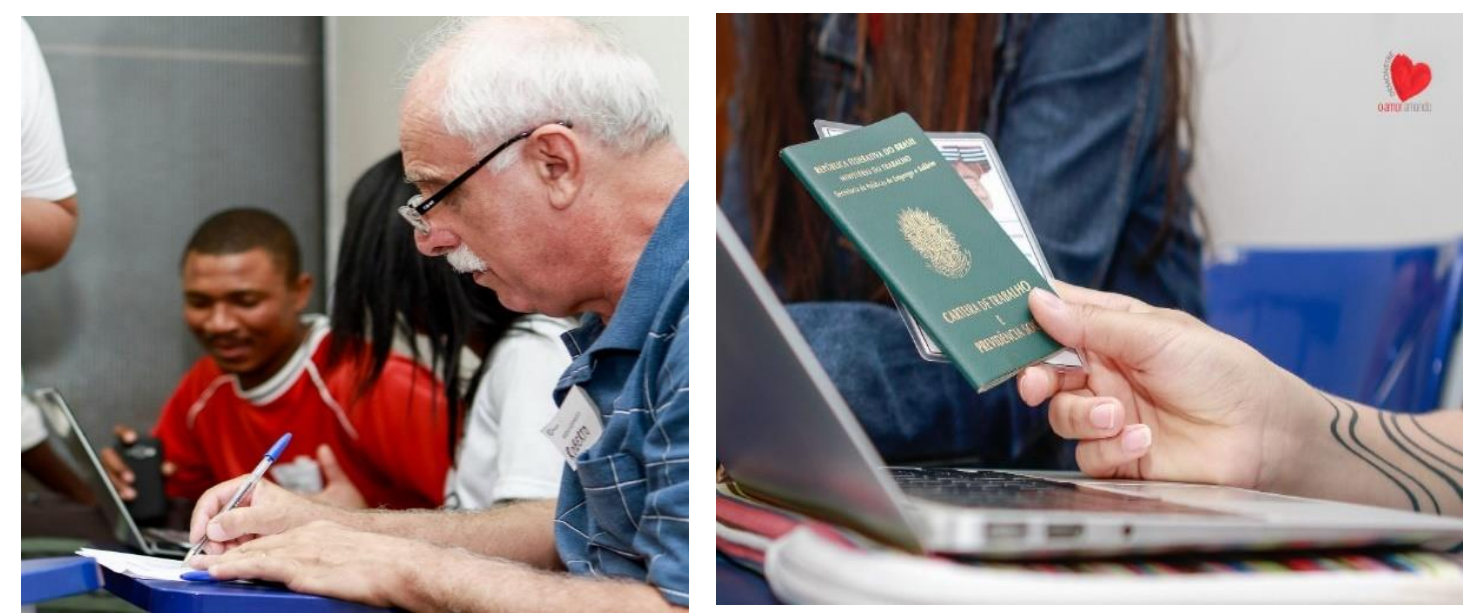

Fonte: Demonstre Amor Amando.

Figura 20 - Registro Elaboração do curriculum e

Portfólio - Despertar Profissional

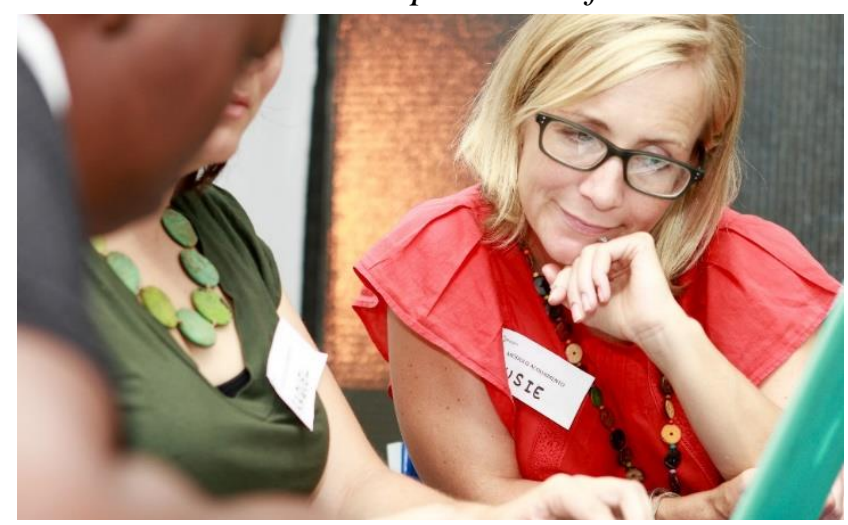

Fonte: Demonstre Amor Amando. 
Essa atividade, tanto pelas minhas observações quanto pelas respostas dos participantes, resultou positivamente em diversos conhecimentos, letramentos e momentos interculturais.

Da mesma forma que foi feito na atividade Chá\&Prosa, ao final da atividade Despertar Profissional, solicitamos a todos que respondessem ao questionário. As questões elaboradas para esse questionário consistiram nas mesmas da atividade anterior, sendo 3 questões de múltipla escolha e uma questão aberta. O questionário foi traduzido em três línguas: português, francês e inglês e os aprendentes tiveram a liberdade de escrever na língua materna deles.

As questões de múltipla escolha tinham o propósito de verificar, de forma mais direta, a opinião sobre o que os aprendentes acharam da atividade, quais foram as dificuldades e qual o tema/assunto que mais gostaram de falar ou ouvir. A questão aberta teve por intuito investigar o que os participantes aprenderam com a atividade e foi a que gerou dados para esse estudo.

Apresento a seguir os resultados das respostas de 20 participantes estrangeiros, referentes às questões de múltipla escolha:

Quadro 17 - Respostas das questões de múltipla escolha - Despertar Profissional

\begin{tabular}{|l|l|}
\hline Participantes & $\begin{array}{l}\text { 1. Marque o você achou da } \\
\text { atividade DESPERTAR } \\
\text { PROFISSIONAL realizada } \\
\text { hoje? }\end{array}$ \\
\hline 0 & muito ruim \\
\hline 0 & ruim \\
\hline 2 & razoável \\
\hline 3 & boa \\
\hline 15 & muito boa \\
\hline
\end{tabular}

\begin{tabular}{|l|l|}
\hline Participantes & $\begin{array}{l}\text { 3. O que você mais gostou da } \\
\text { atividade? (Você pode assinalar } \\
\text { quantos quiser) }\end{array}$ \\
\hline 20 & $\begin{array}{l}\text { saber sobre as leis trabalhistas } \\
\text { brasileira }\end{array}$ \\
\hline 9 & conhecer brasileiros \\
\hline 4 & elaborar o currículo e o portfólio \\
\hline
\end{tabular}

\begin{tabular}{|l|l|}
\hline Participantes & $\begin{array}{l}\text { 2. Quais foram as maiores } \\
\text { dificuldades? (Você pode } \\
\text { assinalar quantos quiser) }\end{array}$ \\
\hline 9 & não tive dificuldades \\
\hline 6 & falar e entender em português \\
\hline 4 & interagir com as pessoas \\
\hline 3 & falar sobre os temas \\
\hline
\end{tabular}

Fonte: Da análise de dados empreendida pela autora. 
Os resultados sugerem que a atividade foi muito bem recebida, sendo considerada muito boa por 15 participantes. As dificuldades foram apontadas por 13 aprendentes, sendo a mais evidenciada falar e entender em português, o que ressalta a necessidade de se desenvolver mais momentos que possibilitem que os aprendentes possam experienciar o português.

O tema que se apresentou mais interessante foi referente às leis trabalhistas. Acredito que esse conhecimento das leis se apresenta importante para os aprendentes, pois, de certa forma, gera um sentimento de proteção e oferece mais autonomia para que possam movimentarse na sociedade brasileira assegurados por leis.

Esse interesse pelo assunto das leis trabalhistas também foi o mais evidenciado nas respostas abertas dessa atividade. Identifiquei na $2^{\text {a }}$ Categoria referente ao Reconhecimento de letramentos e aprendizagens, 9 respostas.

Nessa atividade, ao analisar as respostas dos aprendentes, não consegui identificar dados que correspondessem à $1^{\text {a }}$ Categoria, isto é, estão ausentes nas respostas, no entanto, isso não significa que não ocorreu a aprendizagem e aquisição da língua, até porque a atividade propiciou momentos para a prática do português na oralidade e nas atividades de elaboração do curriculum e do portfólio. Suponho que não houve comentários ligados a essa categoria, porque o que efetivamente mais marcou os aprendentes durante essa atividade foi o conhecimento das leis e a elaboração dos gêneros textuais.

No quadro a seguir apresento as duas primeiras Categorias de análise, juntei as duas em um mesmo quadro para dinamizar o espaço, tendo em vista, que não houve evidências a respeito da $1^{\text {a }}$ Categoria. 
Quadro $18-1^{\mathrm{a}}$ e $2^{\mathrm{a}}$ Categoria

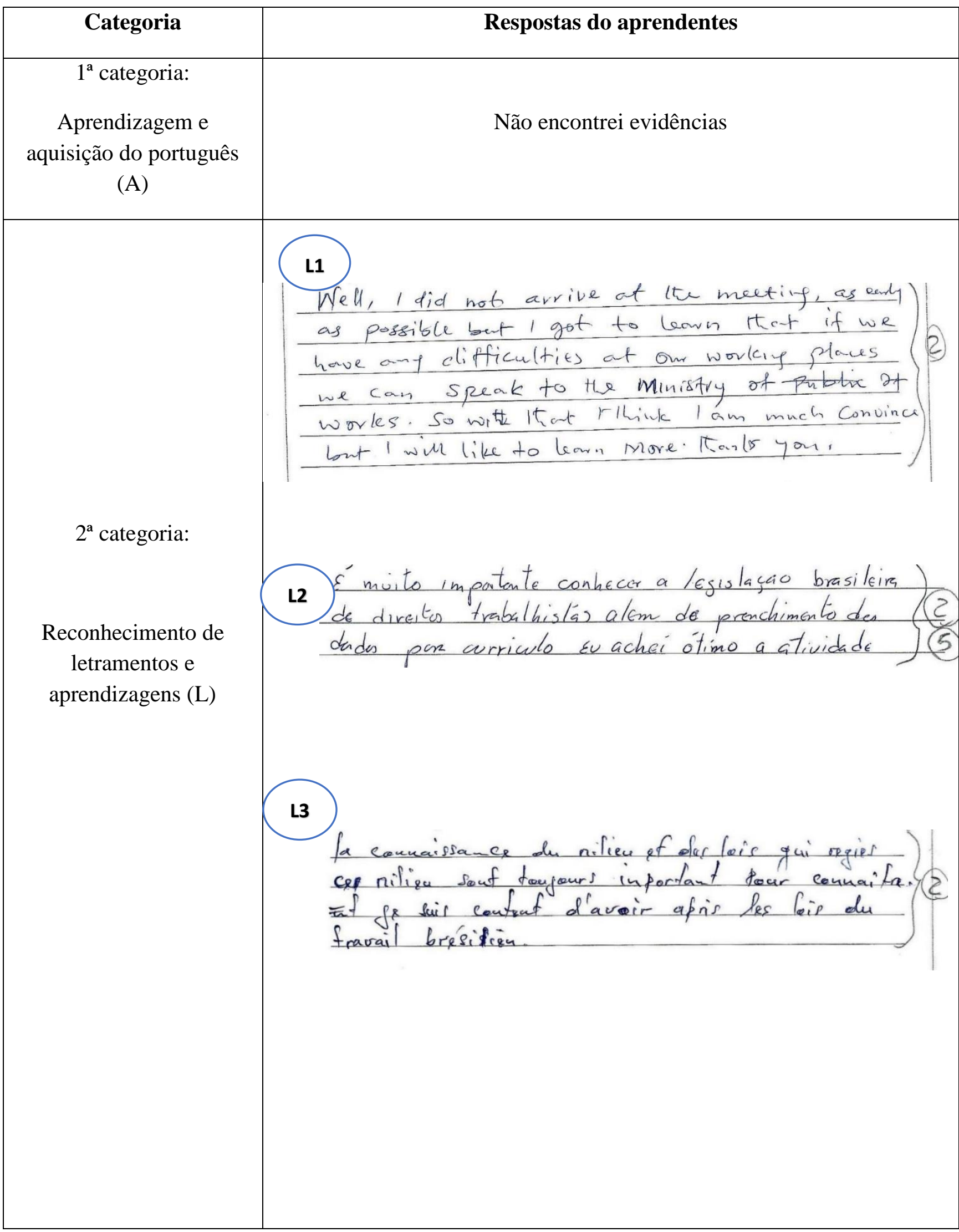




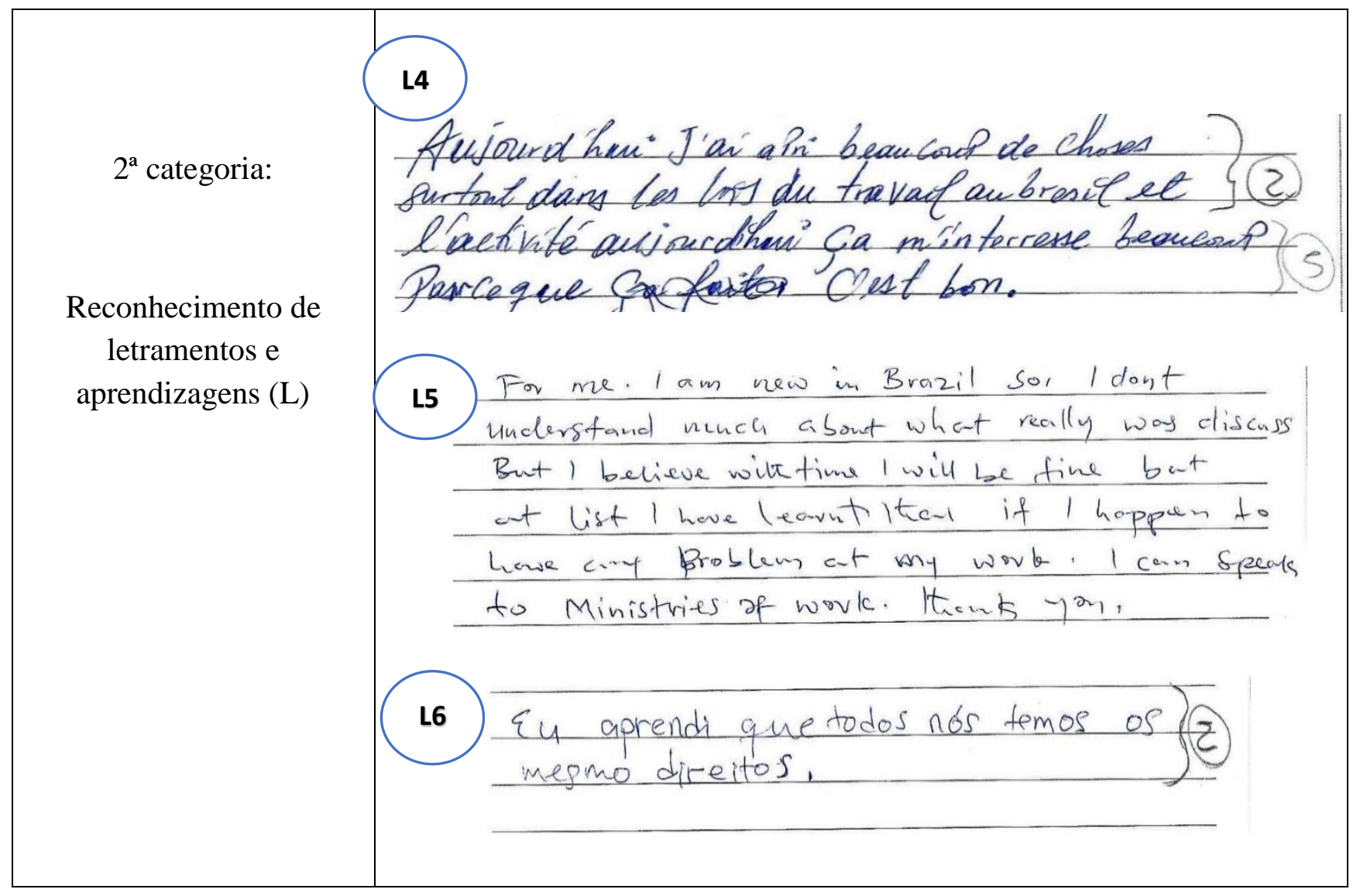

Fonte: Da análise de dados empreendida pela autora.

Assim como discorri, a maioria dos dados gerados pelas respostas dos aprendentes está relacionada à $2^{\mathrm{a}}$ Categoria. Pelas respostas, L2 "É muito importante conhecer a legislação brasileira de direitos trabalhista além do preenchimento de dados para curriculo" e L3 "la connaissance du milieu et des lois que regies ces milieu sont toujours important”, os aprendentes destacam a importância de conhecer as leis trabalhistas brasileiras e a elaboração dos gêneros textuais.

As respostas L1, L4, L5 e L6 expressam explicitamente as aprendizagens que houve y durante a atividade. Nas respostas L1 "if we have any difficulties at work places we can speak to the Ministry of public of work" e L5 "I have learnt that if I happen to have any problem at my work. I can speak to Ministries of work", são frisadas as aprendizagens e letramentos, uma vez que os aprendentes compreenderam que, se houver algum problema em relação a trabalho, deve-se recorrer ao Ministério do trabalho.

Essa informação pode aparentemente parecer simples, no entanto, para os nossos aprendentes ela se torna preciosa, pois eles tiveram o conhecimento que eles têm o direito de reclamar e denunciar, caso não estejam sendo bem tratados no emprego ou mesmo percebam 
que os seus direitos não estão sendo exercidos, tais com a carteira de trabalho não ser assinada, ou se não estiverem tendo o pagamento correto pelas horas-extras ou não estiverem tendo o direito a horas de descanso ou não estiverem recebendo corretamente os benefícios do contrato de trabalho. Essas questões foram apresentadas pelos aprendentes durante a palestra apresentada.

Acredito que esse momento da palestra ficou bem marcado para os participantes, tanto que o programado era para que fosse de 20 minutos e acabou por se estender para 50 minutos, sendo preciso interromper. As dúvidas apresentadas demonstram que é preciso e fundamental trabalharmos mais com a apresentação de leis, com o letramento de práticas sociais referentes às questões de direitos e deveres: como fazer um requerimento ou mesmo uma reclamação ou denúncia ao Ministério Público.

No que concerne à $3^{\text {a }}$ Categoria, também não consegui identificar dados que correspondessem. E no tocante à $4^{\mathrm{a}}$ Categoria houve 3 respostas que expressam sentimento de acolhimento. Apresento a seguir o quadro com as Categorias $3^{\mathrm{a}}$ e $4^{\mathrm{a}}$ :

Quadro $19-3^{\mathrm{a}}$ e $4^{\mathrm{a}}$ Categoria

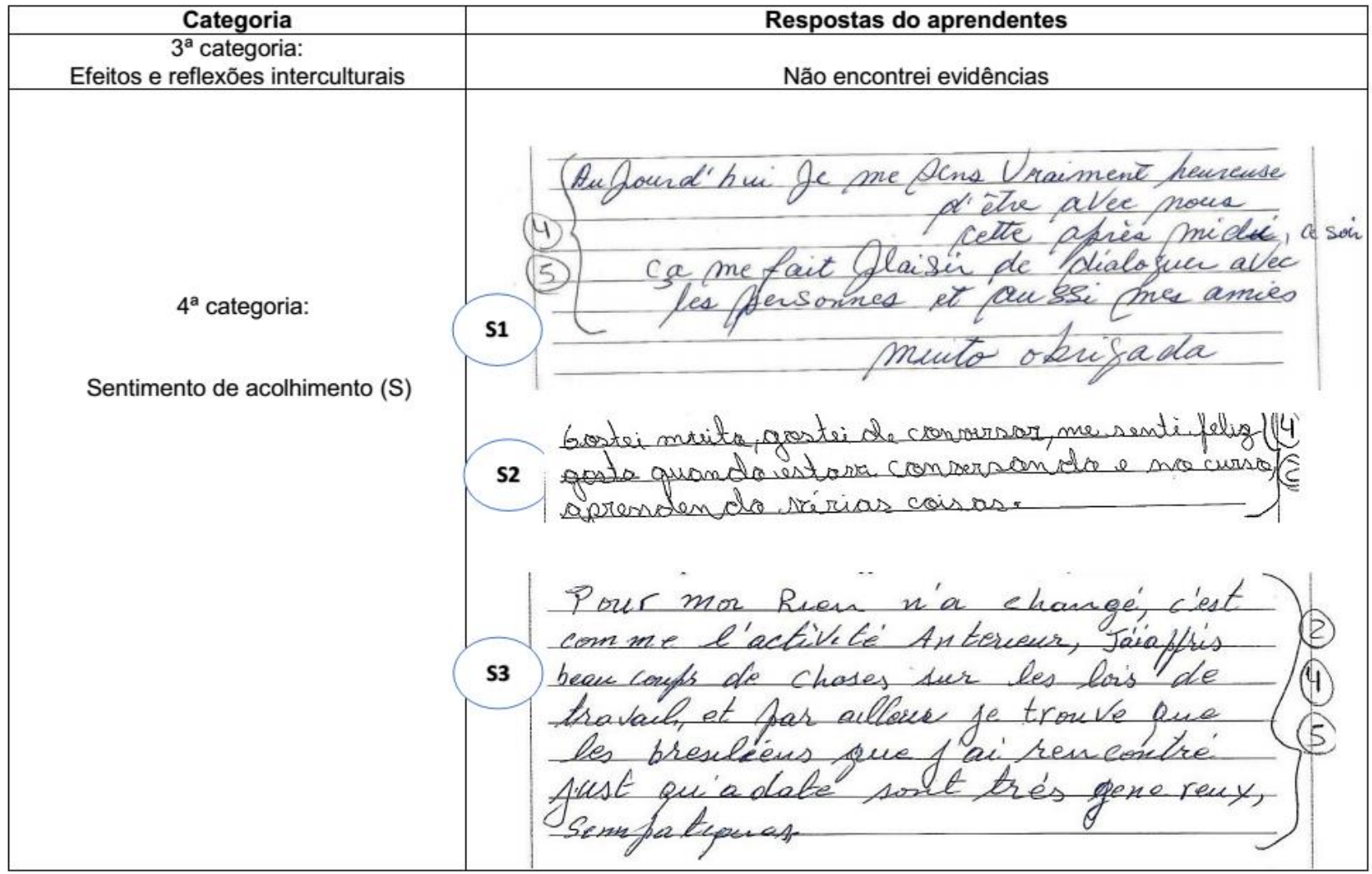

Fonte: Da análise de dados empreendida pela autora. 
Reflexões interculturais não foram registradas nas respostas analisadas, mas observei que houve trocas culturais entre aprendentes e brasileiros no momento de elaboração do curriculum e do portfólio, quando os aprendentes relatavam aos brasileiros suas histórias de vida, suas experiências profissionais, os motivos pelos quais deixaram os seus países e vieram para o Brasil. Acredito que a troca cultural tenha ficado mais evidente para os brasileiros, pois, eles conheceram uma nova cultura por meio das narrativas orais dos aprendentes.

Referente ao sentimento de acolhimento, três respostas expressam o quanto gostaram de conversar durante a atividade e, como marcam as respostas $\mathrm{S} 1$ e $\mathrm{S} 2$, respectivamente "Je me sens vraiment heureuse d'être avec nous" e "me senti feliz", demonstra que esse sentimento de felicidade é em decorrência de terem se sentido bem e possivelmente acolhidos.

Nas respostas dos aprendentes, foram identificadas avaliações positivas sobre a atividade. No quadro logo após apresento duas respostas referentes a percepções sobre a atividade.

Quadro 20 - $5^{\text {a }}$ Categoria

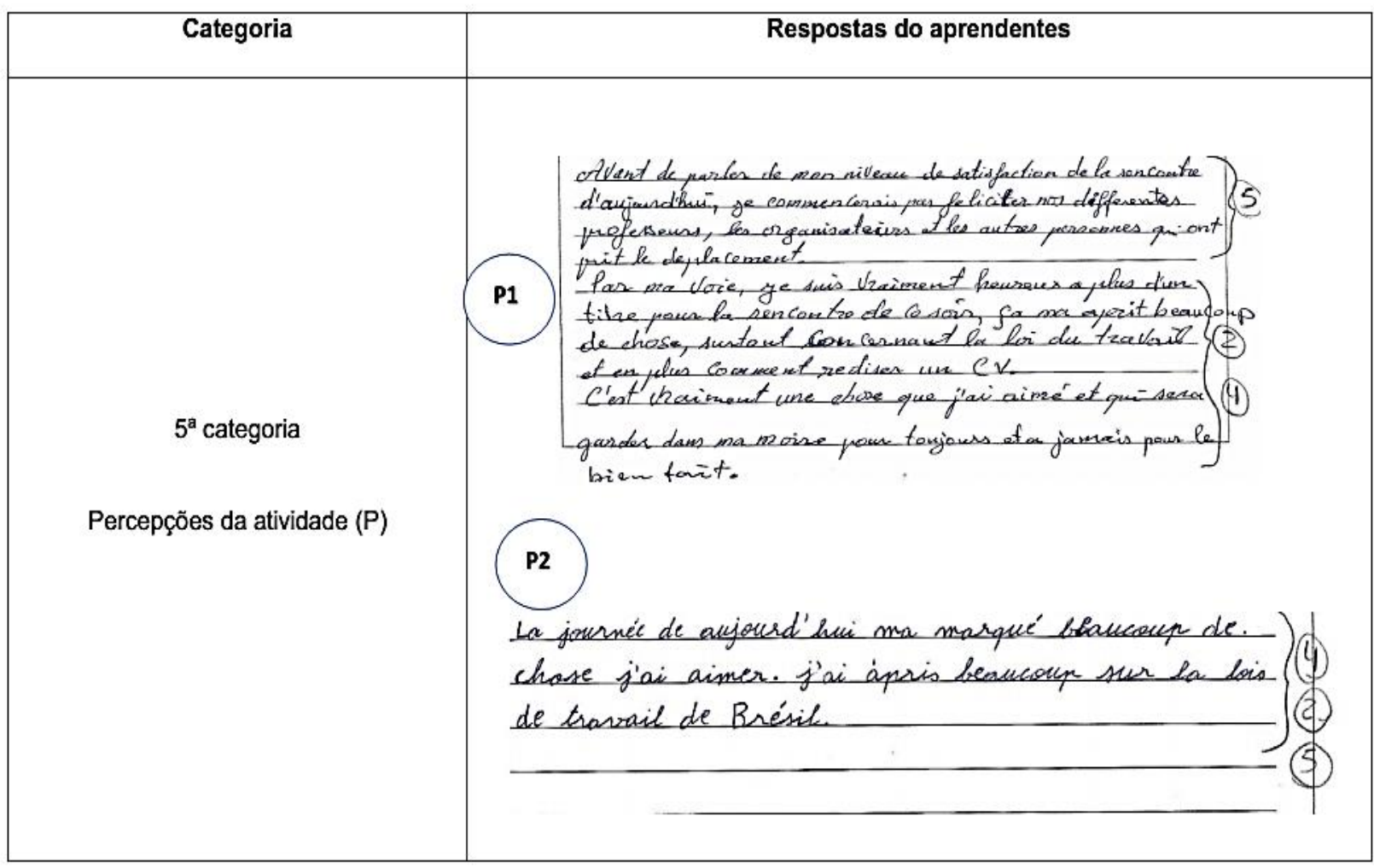

Fonte: Da análise de dados empreendida pela autora.

As respostas sugerem que a atividade foi agradável, como ressaltado pela resposta P2: “La journée de aujourd'hui ma marque beaucoup de chose, j'ai amer". A resposta P1 também 
diz sobre o nível de satisfação que a noite lhe trouxe: "avant de parler de mon niveau de satisfation de la reencontre d'aujourd'hui, je commencerais pour feliciter nos diferentes professeurs, les organizateurs et le autres personnes que on fait le deplacement”.

Essas evidências sobre a percepção das atividades interculturais confirmam o quão valiosas foram e tão bem recebidas pelos participantes estrangeiros. Considero que as duas atividades relatadas e analisadas neste estudo não foram úteis e importantes somente para os participantes estrangeiros, mas suponho que para todos aqueles que participaram, para nós professores, para os voluntários, para os brasileiros, pois, todos foram participantes de processo de aprendizagens, de letramentos e de momentos riquíssimos de trocas culturais.

Pela minha perspectiva, as atividades interculturais contribuíram muito para dinamizar o nosso ensino, pois elas possibilitaram momentos divertidos para praticar português e para ampliar redes de amizades com brasileiros e de conhecimentos culturais, sociais da sociedade brasileira.

Dessa forma, avalio que as atividades interculturais conseguiram concretizar os objetivos propostos de ensino e, para além disso, possibilitaram aos aprendentes o acesso aos bens simbólicos da língua, da educação e da amizade. Esse intercâmbio proposto pelas atividades entre os aprendentes e brasileiros resultou riquíssimo para ambos, pois todos puderam compartilhar histórias e risadas, tendo a possibilidade de trabalhar com a alteridade e assim, desenvolver a tolerância e o respeito. 


\section{CAPÍTULO V: CONSIDERAÇÕES FINAIS}

Neste capítulo retomo o objetivo e as perguntas de pesquisa e, diante deles, faço uma análise e reflexão sobre como essa pesquisa relatada nesta dissertação conseguiu concretizálos. Em seguida, discorro sobre as contribuições e limitações deste estudo e apresento, baseando-me nessa pesquisa, perspectivas de estudos em outros contextos.

\subsection{Retomando o objetivo e perguntas de pesquisa}

A pesquisa teve por finalidade definir objetivos do ensino-aprendizagem de português como língua de acolhimento e, de acordo com esses, reelaborar materialidades de ensino, especificamente o material didático e os procedimentos para experienciar o português.

Esse objetivo foi alcançado por meio de duas perguntas de pesquisa. A primeira pergunta: 1. Quais são os objetivos do ensino-aprendizagem de português para a turma do Acolher 1 no Módulo Acolhimento? consistiu em dissertar sobre os objetivos definidos para o ensino-aprendizagem de português na turma analisada. A segunda pergunta: 2. Como o material didático e os procedimentos para experienciar a língua buscaram atender aos objetivos propostos para o ensino-aprendizagem do português? resultou na análise feita dos módulos Apresentação e Trabalho e das atividades interculturais - Chá\&Prosa e Despertar Profissional.

\subsection{Contribuições do estudo}

O material didático reelaborado para turma do Acolher 1, especificamente os módulos Apresentação e Trabalho, se apresentou como um recurso e suporte necessário para auxiliar na aprendizagem e na aquisição da língua portuguesa, no desenvolvimento de letramentos de práticas socioculturais e na mediação de trocas culturais.

Referente a aprendizagem da língua, avalio que os módulos contribuíram para explicitar de maneira mais sistematizada as estruturas gramaticais e o funcionamento da língua portuguesa. A aquisição da língua foi mais evidenciada nas produções de textos escritos e orais realizadas pelo(a)s aprendentes em sala de aula, tais como a elaboração de uma biografia, de um currículo, de um e-mail e de um portfólio.

O letramento de práticas socioculturais esteve entrelaçado com essas produções escritas e orais de gêneros textuais. Por meio dos gêneros desenvolvidos, pude mediar conhecimentos 
de como estruturá-lo na língua portuguesa e para qual finalidade e maneira de utilizá-los na sociedade brasileira.

Ao que concerne as trocas culturais, observei que essas foram realizadas durante as aulas e também por meio da elaboração dos gêneros textuais, especificamente na produção do gênero biografia em que o(a)s aprendentes escreveram e apresentaram oralmente uma personalidade do país de origem deles. No entanto, reconheço que esse aspecto de interculturalidade deve ser melhor desenvolvido ou mesmo modificado, para que não fique apenas como apresentação, mas que consiga extrapolar esse sentindo.

Vale destacar que a elaboração do MD seguiu as quatro etapas propostas por Leffa (2003) sobre a elaboração do material didático para o ensino de línguas. Primeiro, de acordo com a etapa análise, realizei uma investigação das necessidades dos aprendentes por meio da experiência como docente que tive em turmas anteriores e por meio dos questionários sobre Perfil aplicados no primeiro dia de aula da turma analisada. Em segundo, conforme a etapa desenvolvimento, defini objetivos de ensino-aprendizagem de português a partir da análise das necessidades dos aprendentes e (re)elaborei conteúdos pertinentes para atingir os objetivos propostos pelo ensino. Em terceiro, conforme a etapa implementação, apliquei o MD na turma, Acolher 1, analisada neste estudo. E em quarto, em consoante com a etapa avaliação, realizei a análise apresentada nesta dissertação.

Dessa maneira, considero que o material didático auxiliou na aprendizagem e na aquisição de português e no desenvolvimento de letramentos, no entanto, somente o MD, não foi suficiente para promover efetivamente momentos interculturais e sentimento de acolhida. Outras ações e procedimentos para experienciar a língua-alvo se tornaram imprescindíveis, tais como as atividades interculturais.

As atividades interculturais foram um dos procedimentos desenvolvidos durante o ensino que contribuíram positivamente para consolidar os objetivos do ensino-aprendizagem de português propostos para a turma do Acolherl, sobretudo, os de possibilitar o desenvolvimento da competência comunicativa, da competência intercultural e propiciar o sentimento de acolhida.

Por meio das duas atividades realizadas, Chá\&Prosa e Despertar Profissional, os participantes estrangeiros, especificamente os que estavam inscritos no Módulo Acolhimento, puderam aplicar na prática o que aprenderam em sala de aula, no entanto, de maneira mais informal e espontânea, o que contribuiu para esses desenvolverem a competência comunicativa. As atividades também colaboraram para os participantes estrangeiros terem contato mais próximo com brasileiros, criando redes de amizade e vivenciando trocas culturais. 
As atividades interculturais também contribuíram para promover um acolhimento aos migrantes e refugiados, e isso pôde ser observado pela análise das respostas apresentadas nesta dissertação e também pelas observações que fiz em sala de aula após as atividades. Observei que alguns aprendentes estavam mais animados nas aulas e ansiosos para que acontecessem outras atividades com brasileiros.

Além de promover esse acolhimento, considero que as atividades interculturais foram importantes para tornar visível o público migrante e refugiado para algumas pessoas da comunidade de Brasília, e essa visibilidade se torna necessária e importante, uma vez que pode contribuir para descontruir estereótipos, diminuir preconceitos e exercitar momentos de alteridade e solidariedade.

Pela minha perspectiva, as atividades interculturais contribuíram muito para dinamizar o nosso ensino, pois elas possibilitaram momentos divertidos para praticar português, para ampliar redes de amizades com brasileiros e para mediar conhecimentos culturais, sociais da sociedade brasileira.

Considero que os resultados alcançados nesta pesquisa mostram que as materialidades analisadas buscaram efetivamente concretizar os objetivos do ensino, no entanto, em níveis diferenciados. O material didático auxiliou mais na aprendizagem e aquisição do português e no desenvolvimento de letramentos, enquanto as atividades interculturais propiciaram interculturalidades e sentimento de acolhida.

Dessa maneira, tendo em vista que a área de ensino de português como língua de acolhimento ainda se apresenta relativamente nova no Brasil, não tendo, portanto, muitos modelos disponíveis ou divulgados do ensino-aprendizagem nesse contexto, espero que esse estudo possa contribuir para essa área de ensino-aprendizagem de PLAc e com a área de ensino de línguas estrangeiras, uma vez que, neste estudo, foram discorridos e analisados processos e materialidades de ensino de línguas para contextos específicos.

\subsection{Limitações do estudo}

Considero que a principal limitação deste estudo foi o pouco tempo que tive para a escrita, pois, diante de tantas experiências vividas no âmbito do ensino-aprendizagem aqui relatadas, e com tantos dados gerados pelos instrumentos de coleta de dados, o tempo disponibilizado para a escrita se apresentou curto, porém, compreendo que isso faz parte do processo de um mestrado. 
Outra limitação que identifico é o episódio que tivemos com o DFTRANS que, como consequência, implicou redução da carga horária do curso do Acolher 1, e assim tivemos menos tempo para desenvolver outros módulos e realizar outras atividades interculturais que haviam sido planejadas.

\section{$5.4 \quad$ Perspectivas de estudos}

Como mencionado, no Brasil, de maneira ainda incipiente, a especialidade de Português como Língua de Acolhimento (PLAc) tem se desenvolvido e necessitado de olhares mais cuidados dos profissionais da área de ensino-aprendizagem de línguas.

Neste estudo, dediquei-me a discorrer e analisar os objetivos de ensino e a reelaboração das materialidades do material didático e de procedimentos para experienciar a língua. No entanto, há outros processos que precisam ser investigados, tais como os processos de aprendizagem e aquisição da língua, tendo em vista as culturas de aprender; como a aquisição de português pelos imigrantes e refugiados tem resultado em integração e inserção na sociedade brasileira; assim como, de que maneira a aquisição da língua tem colaborado como mecanismo de defesa e ressignificação de identidades.

Outra investigação que considero fundamental nesse âmbito de ensino é referente aos processos de aprendizagem e aquisição do português por crianças e mulheres imigrantes e refugiadas. É preciso investigar como tem sido desenvolvido esse ensino e de que maneira ele tem contribuído para promover a aquisição da língua-cultura e para o acolhimento dessas crianças e mulheres. Dessa forma, desejo que a pesquisa relatada nesta dissertação possa estimular outras pesquisas no âmbito do ensino-aprendizagem de português como língua de acolhimento, ou ainda de outras áreas de pesquisa. 


\section{REFERÊNCIAS}

ABRAHÃO, M. H. V. Metodologia na investigação das crenças. In: BARCELOS, A. M. F. e ABRAHÃO, M. H. V. (orgs.). Crenças e ensino de línguas. Campinas: Pontes, 2006, p. 219230

ADAMI, Hervé. La formation linguistique des migrants. CLE International, 2009.

ALBUQUERQUE, Jeniffer; GABRIEL, Maria; ANUNCIAÇÃO, Renata Franck Mendonça de. O papel do entorno no acolhimento e na integração de populações migrantes para o exercício pleno da cidadania. In: GEDIEL, José Antônio Peres; GODOY, Gabriel Gualano de (Orgs.). Refúgio e hospitalidade. Curitiba: Kairós Edições, 2016, p.359-380.

ALMEIDA, Paulo Sérgio de. Conselho Nacional de Imigração (CNIg): Políticas de Imigração e Proteção ao Trabalhador Migrante ou Refugiado. In: Cadernos de Debates Refúgio, Migrações e Cidadania, v.4, n. 4 (2009). Brasília: Instituto Migrações e Direitos Humanos. $\begin{array}{llllll}\text { v.1, n. } & 1 & \text { (2006) } & \text { [Anual]. }\end{array}$ $<$ http://www.acnur.org/t3/fileadmin/Documentos/portugues/Publicacoes/2009/cadernos/Cader no_de_Debates_4.pdf?view=1>. Acesso em: 10 jan. 2017.

Governo prorroga visto humanitário para haitianos. Repórter NBR. Portal Brasil, com informações do Ministério do Trabalho 19h. 15 set. 2016. Disponível em: $<$ http://www.brasil.gov.br/cidadania-e-justica/2016/09/governo-prorroga-visto-humanitariopara-haitianos>. Acesso em: 14 jan. 2017.

ALMEIDA FILHO, J. C. P. A Abordagem orientadora da ação do professor. In: ALMEIDA FILHO, J. C.P (Org.). Parâmetros atuais para o ensino de Português Língua Estrangeira. Campinas: Pontes, 2007, p.13-28.

Dimensões Comunicativas no Ensino de Línguas. Edição comemorativa, corrigida e ampliada. Campinas: Pontes Editores, 2013.

. A Operação Global de Ensino de Línguas e o Modelo OGEL. In: ALMEIDA FILHO, J. C.P (Org.). Quatro Estações no Ensino de Línguas. Campinas: Pontes, 2012, p.9-28.

Ensinar uma nova língua para aquisição. In: ALMEIDA FILHO, J. C.P (Org.). Fundamentos de abordagem e Formação no Ensino de PLE e de outras Línguas. Campinas: Pontes, 2011, p.51-63. 
Almeida Filho (UnB): métodos mais apropriados são os de cada professor. Jornal do

Professor. 09 abr. 2010.2 Disponível em: <http://portaldoprofessor.mec.gov.br/conteudoJornal.html?idConteudo=1068>. Acesso em: 28 dez. 2016.

Escolha e produção de material didático para um ensino comunicativo de línguas. In: CONTEXTURAS: ensino crítico de língua Inglesa. São Paulo: APLIESP, 1994, v.2.

O ensino de português para estrangeiros nas Universidades brasileiras. In: ALMEIDA FILHO, J. C. P; LOMBELLO, L. C. (Orgs.). Identidade e Caminhos no Ensino de Português para Estrangeiros. Campinas, UNICAMP: Pontes Editores, 1992, p.11-16.

O planejamento de um curso de língua: a harmonia do material-insumo com os processos de aprender, ensinar e refletir sobre a ação. Mímeo, Universidade Estadual de Campinas, São Paulo, 1996.

Sobre competências de ensinar e de aprender línguas. In: ALMEIDA FILHO, J. C. P. (Org.). Competências de Aprendizes e Professores de Línguas. Campinas: Pontes Editores, 2014, p.11-34.

. Entrevista (2010). Disponível em < http://www.sala.org.br> Acesso em: 20. dez.2016

; MOUTINHO, Ricardo. Sentido de ensinar PLE no mundo. In: ALMEIDA FILHO, J. C.P (Org.). Fundamentos de abordagem e Formação no Ensino de PLE e de outras Línguas. Campinas: Pontes, 2011, p.39-50.

; SCHMITZ, J.R. Glossário de Linguística Aplicada. Português Inglês/ Inglês Português. Campinas: Pontes Editores, 1998.

ALTO COMISSARIADO DAS NAÇÕES UNIDAS PARA REFUGIADOS - ACNUR. Disponível em: <http://www.acnur.org/portugues/o-acnur/>. Acesso em: 10 jan. 2017.

_. Dados sobre refúgio no Brasil. Disponível em: < http://www.acnur.org/portugues/recursos/estatisticas/dados-sobre-refugio-no-brasil/ > . Acesso em: 10 jan. 2017.

; UNITED NATIONS HIGH COMMISSIONER FOR REFUGEES (UNHCR). Global trends: forced displacement in 2015. Switzerland: UNCHR, 2016 [Relatório]. Disponível em: <https://s3.amazonaws.com/unhcrsharedmedia/2016/2016-06-20-globaltrends/2016-06-14Global-Trends-2015.pdf>. Acesso em: 14 jun. 2016. 
AMADO, R. S. O ensino de português como língua de acolhimento para refugiados. In: Revista da Sociedade Internacional Português Língua Estrangeira - SIPLE. Brasília, 2013, ed.7, ano 4 , n.2. Disponível em: $<$ http://www.siple.org.br/index.php?option=com_content\&view=article\&id=309:o-ensino-deportugues-como-lingua-de-acolhimento-para-refugiados\&catid=70:edicao-7\&Itemid=113>. Aceso em: 09 out. 2016.

ANÇÃ, Maria Helena. Português-língua de acolhimento: entre contornos e aproximações. In: Congresso Internacional sobre História e Situação da Educação em África e Timor. Lisboa: FCSH/Universidade Nova, 2003, p.1-6

ANDRÉ, M. E. D. (1995). Etnografia da prática escolar. 6. ed. Campinas, SP: apirus, 2001.

BARBOSA, Lúcia Maria de Assunção; RUANO, Bruna Pupatto. Acolhimento, sentidos e práticas de ensino de português para migrantes e refugiados, na universidade de brasília e na universidade federal do paraná. In: GEDIEL, José Antônio Peres; GODOY, Gabriel Gualano de (Orgs.). Refúgio e hospitalidade. Curitiba: Kairós Edições, 2016, p.321-336.

; SÃO BERNARDO, M. A. Português para refugiados: especificidades para acolhimento e inserção. In: SIMÕES, D. M. P; FIGUEIREDO, F. J. Q. (Orgs.). Metodologias em/de linguística aplicada para ensino e aprendizagem de línguas. Campinas: Pontes Editores, 2014, p.269-278.

BOGDAN, R. C; BIKLEN, S. K. Qualitative research for education: an introduction to theory and methods. Needham Heights, MA: [s.n.], 1998.

Investigação Qualitativa em Educação. Colecção Ciências da Educação. Porto: Porto Editora, 1994.

BRASIL. Lei n. 9.474, de 22 de julho de 1997. Define mecanismos para a implementação do Estatuto dos Refugiados de 1951, e determina outras providências. . Portal da Legislação: Leis Ordinárias. 1997. Disponível em: < http://www.planalto.gov.br/ccivil_03/Leis/L9474.htm>. Acesso em: 10 jan. 2017.

CHARLEAUX, João Paulo. Os refugiados que o Brasil acolhe: um balanço de 2010 a 2015 . In: Jornal Nexo. 102 mai. 2016. Disponível em: < https://www.nexojornal.com.br/expresso/2016/05/10/Os-refugiados-que-o-Brasil-acolhe-umbalan\%C3\%A7o-de-2010-a-2015>. Acesso em: 10 jan. 2017. 
Qual a diferença entre visto humanitário e refúgio. In: Jornal Nexo. 20 jun. 2016 (atualizado 21/Jun 08h25). Disponível em: <https://www.nexojornal.com.br/expresso/2016/06/20/Qual-a-diferen\%C3\%A7a-entre-vistohumanit\%C3\%A1rio-e-ref\%C3\%BAgio>. Acesso em: 10 jan. 2017.

CABETE, M. A. C. S. S. O processo de ensino-aprendizagem do português enquanto língua de acolhimento. Dissertação (Mestrado em Língua e Cultura Portuguesa). Universidade de Lisboa, Lisboa, 2010.2 Disponível em: <http://repositorio.ul.pt/bitstream/10451/4090/1/ulf1081236_tm.pdf >. Acesso em: 18 de janeiro de 2015.

CELLARD, André. A análise documental. In: (Vários autores). A pesquisa qualitativa: enfoques epistemológicos e metodológicos. Petrópolis: Vozes, 2010, p.295-315.

CENOZ, J. The acquisition of additional languages. ELIA. Spain, 2008, v. 8, p. 219-224.

CHIZZOTTI, A. Pesquisa qualitativa em ciências humanas e sociais. Petrópolis: Vozes, 2006, p.33-60.

CORREIA, Maria da Conceição Batista. A observação participante enquanto técnica de investigação. In: Pensar Enfermagem. vol. 13, n. 2, $2^{\circ}$ Semestre de 2009. Disponível em: < http://pensarenfermagem.esel.pt/files/2009_13_2_30-36.pdf>. Acesso em: 16 out. 2014.

COSTA, M. J. I; D’ANDREA, A. G. N. O; SANTANA, I. As quatro paredes de uma sala de aula: experiência como professores de PFOL. In: FURTUSO, Viviane Bagio. Formação de professores de Português para Falantes de Outras Línguas: reflexões e contribuições. Londrina: EDUEL, 2009, vol.1, p.79-89.

DENZIN, N. K; LINCOLN, Y. S. Introdução: a disciplina e a prática da pesquisa qualitativa. In: DENZIN, N. K; LINCOLN, Y. S. O planejamento da pesquisa qualitativa: teorias e abordagens. Porto Alegre: Artmed, 2006, p.15-41.

DÖRNYEI, Z. Questionnaires in second language research: Construction, administration, and processing. Mahwah, New Jersey: Lawrence Erlbaum, 2003.

FREEBODY, P. Qualitative Research in Education: interaction and practice. London: Sage, 2003.

FREIRE, Paulo. Pedagogia da autonomia: saberes necessários à prática educativa. São Paulo: Paz e terra, 1996. 
FLICK, U. Uma introdução à pesquisa qualitativa. Trad. Sandra Netz. 2. ed. - Porto Alegre: Bookman, 2004.

GROSSO, Maria José. As competências do Utilizador elementar no contexto de acolhimento. $2007 . \quad$ Disponível em: <http://www.dge.mec.pt/sites/default/files/Basico/Documentos/portugues_falantes_outras_lin guas1.pdf >. Acesso em: 09 nov. 2016.

Língua de Acolhimento, Língua de Integração. In: Horizontes de Linguística Aplicada, 2010, v. 9, n.2, p.61-77. Disponível em: <http://periodicos.unb.br/index.php/horizontesla/article/download/5665/4694>. Acesso em: 01 nov. 2015.

INSTITUTO MIGRAÇÕES E DIREITOS HUMANOS - IMDH. Disponível em: <http://www.migrante.org.br/migrante/>. Acesso em: 10 jan. 2017

KRAMSCH, Claire. O componente cultural na linguística aplicada.Trad. Lucia Maria de Assunção Barbosa. Contexturas, ensino de línguas inglesa, 15-2009, p. 115-134.

LAVILLE, C; DIONNE, J. A. A construção do saber: Manual de metodologia da pesquisa em ciências humanas. Porto Alegre: Armed/Belo Horizonte: Editora da UFMG, 1999.

LEFFA, V. J. Como produzir materiais para o ensino de línguas. In: LEFFA, Vilson. J. (Org). Produção de materiais de ensino: teoria e prática. Pelotas: EDUCAT, 2003, p.15-41. Disponível em: <http://www.leffa.pro.br/textos/trabalhos/prod_mat.pdf>. Acesso em: 14 mar. 2016.

Aspectos políticos da formação do professor de línguas estrangeiras. In: LEFFA, Vilson J. (Org.). O professor de línguas estrangeiras; construindo a profissão. Pelotas, 2001, v. 1, p. 333-355.

Metodologia do ensino de línguas. In: BOHN, H. I; VANDRESEN, P. Tópicos em linguística aplicada: O ensino de línguas estrangeiras. Florianópolis: Ed. da UFSC, 1988. p.211-236. <http://www.leffa.pro.br/textos/trabalhos/Metodologia_ensino_linguas.pdf>. Acesso em: 04 dez. 2016.

LUDKE, M; ANDRÉ, M. E. D. A. A pesquisa em educação: abordagens qualitativas. São Paulo: EPU, 1986. 
MAGALHÃES, I. Letramento, intertextualidade e prática social crítica. In: MAGALHÃES, I. (Org.) Discurso e práticas de letramento. Campinas, SP: Mercado de Letras, 2012, p.17-68.

MARCONI, M. A. e LAKATOS, E. M. Fundamentos de metodologia científica. 5a ed. São Paulo: Atlas, 2003.

MARCUSCHI, Luiz Antônio; XAVIER, Antonio Carlos. Hipertexto e gêneros digitais: novas formas de construção de sentido. 3ed. São Paulo: Cortez, 2010.

MAIA, S. F; MENDES, B. M. M. A formação e a prática pedagógica do professor de língua inglesa no ensino superior: desafios da sociedade contemporânea. In: Atos de pesquisa em Educação - PPGE/ME FURB, ISSN 1809- 0354 v. 4, nº 2, p. 193-205, maio/ago, 2009.

MENDES, Edleise. Por que ensinar língua como cultura? In: SANTOS, Percilia; ALVAREZ, Maria Luisa Ortiz (Orgs.). Língua e Cultura no contexto de português língua estrangeira. Campinas: Pontes Editores, 2010, p.56 -77.

MERRIAM, Sharan B. Case study research in education: a qualitative approach. San Francisco: Jossey-Bay Publishers, 1988.

Qualitative research and case study applications in education. San Francisco: Jossey-Bay Publishers, 1998.

MORTATTI, M. R. L. EDUCAÇÃO E LETRAMENTO. São Paulo: UNESP, 2004.

MOURA FILHO, A. C. L. Pelo inglês afora: carreira profissional e autonomia na aprendizagem de inglês como língua estrangeira. 286f. 2005. Tese - (Doutorado em Estudos Linguísticos) - Faculdade de Letras, Universidade Federal de Minas Gerais, Belo Horizonte, 2005.

NÚCLEO DE ENSINO E PESQUISA EM PORTUGUÊS PARA ESTRANGEIROS NEPPE. Disponível em: <http://www.neppe.unb.br/br/>. Acesso em: 10 jan. 2017.

OBSERVATÓRIO DE MIGRAÇÕES INTERNACIONAIS - OBMigra. Disponível em: <http://portal.mte.gov.br/obmigra/home.htm>. Acesso em: 10 jan. 2017.

OLIVEIRA, A. M. Processamento da linguagem num contexto migratório e de integração. In: GROSSO, M. Educação em Português e Migrações. Lisboa: Lidel, 2010, p. 30-47. 
PATROCÍNIO, Elizabeth M. F. do. Método no Ensino de Português Língua Estrangeira. In: Parâmetros Atuais no Ensino de Português Língua Estrangeira. ALMEIDA FILHO, J.C.P. (Org.), Campinas: Pontes, 1997, p. 59-73.

RAJAGOPALAN. Kanavillil. Por uma linguística crítica: linguagem, identidade e questão ética. São Paulo: Parábola, 2003.

RIOS, G. Letramento, discurso e gramática funcional. In: Cadernos de Linguagem e Sociedade. Brasília, 2010, v.11, n.2, p.167-183.

- Considerações sobre letramento, escolarização e avaliação educacional. In: RESENDE, V; PEREIRA, F. (Orgs.). Práticas socioculturais e discurso: Debates Transdisciplinares. Covilhã: LabCom Books, 2010, p.77-108.

SANTOS, M; ALMEIDA FILHO, J. C. P. Análise de Abordagem de Ensino de Língua no Limite. In: Revista SIPLE. Brasília, 2011, ano 2, n.2. On-line versão. Disponível em: $\quad<$ http://www.siple.org.br/index.php?option=com_content\&view=article\&id=215:6analise-de-abordagem-de-ensino-de-lingua-no-limite \&catid=62:edicao-3\&Itemid=107> .

Acesso em: 20 set. 2016.

SÃO BERNARDO, Mirelle Amaral. Português como Língua de Acolhimento: um estudo com imigrantes e pessoas em situação de refúgio no Brasil. 2016. 206 f. Tese (Doutorado) Universidade Federal de São Carlos, São Carlos, 2016. Disponível em: $<$ https://repositorio.ufscar.br/bitstream/handle/ufscar/8126/TeseMASB.pdf?sequence=1\&isAl lowed=y>. Acesso em: 07 fev. 2017.

SCARAMUCCI, M. V. R. Avaliação de Rendimento no Ensino-Aprendizagem de Português Língua Estrangeira. In: ALMEIDA FILHO, J. C.P (Org.). Parâmetros atuais para o ensino de Português Língua Estrangeira. Campinas: Pontes, 1997, p.75-88.

O professor avaliador: sobre a importância da avaliação na formação do professor de língua estrangeira. In: ROTTAVA, L; SANTOS, S.R. (Orgs.) Ensino-aprendizagem de Línguas: Língua Estrangeira. Coleção Linguagens, Ijuí: Editora da UNIJUI, 2006, p. 49-64.

SOCIEDADE DE LINGUÍSTICA APLICADA, CULTURA DIGITAL E EDUCAÇÃO SALA. Disponível em: <http://glossario.sala.org.br>. Acesso em: 14 jan. 2017. 
SOUTO, M.V. L; ALÉM, A. O. F. G; BRITO, A. M. de S; BERNARDO, C. Conceitos de língua estrangeira, língua segunda, língua adicional, língua de herança, língua franca e língua transnacional. In: Revista Philologus. Anais da IX JNLFLP. Rio de Janeiro: CiFEFiL, ano 20, n. 60, Supl. 1: $\quad$ set.-dez, 2014. Disponível em: <http://www.filologia.org.br/revista/60supl/070.pdf>. Acesso em: $01 \mathrm{dez} .2016$.

STAKE, Robert E. Case studies. In: Denzin, N.K\&Lincoln, Y.S (eds.).Handbook of qualitative reseach. London: Sage, 1994. p. 236-247.

STREET, B. Eventos de letramento e práticas de letramento: teoria e prática nos novos estudos do letramento. In: MAGALHÃES, I. (Orgs.). Discurso e práticas de letramento. Campinas: Mercado de Letras, 2012, p.69-92.

STREET, B. V. Letramentos sociais: abordagens críticas do letramento no desenvolvimento, na etnografia e na educação. Trad.: Marcos Bagno. São Paulo: Parábola Editorial, 2014.

TARDIF, Maurice. Saberes docentes e formação profissional. Petrópolis: Vozes, 2002.

TOSSATI, N. M. Gêneros textuais em livros didáticos para ensino de português para estrangeiros: ocorrência e funcionalidade. Anais do SILEL. Uberlândia: EDUFU, 2009 vol. 1. Disponível em: <https://oportuguesdobrasil.files.wordpress.com/2015/02/livros-plegeneros-tosatti.pdf>. Acesso em: 09 jan. 2016.

VIANA, Nelson. Planejamento de Cursos de línguas - Pressuposto e Percurso. In: ALMEIDA FILHO, J.C.P. (Org.). Parâmetros Atuais no Ensino de Português Língua Estrangeira. Campinas: Pontes, 1997, p.29-48.

VILAÇA, M. L. C. O material didático no ensino de língua estrangeira: definições, modalidades e papéis. Disponível em: $<$ http://publicacoes.unigranrio.edu.br/index.php/reihm/article/viewFile/653/538>. Acesso em: 11 nov. 2016.

WIKIPEDIA: the free encyclopedia [Internet]. St. Petersburg (FL): Wikimedia Foundation, Inc. 2001 - [citado em 26 nov. 2016]. Região Administrativa (Distrito Federal). Disponível em: $\quad$ https://pt.wikipedia.org/wiki/Regi\%C3\%A3o_Administrativa_(Distrito_Federal)>. Acesso em: 26 nov. 2016.

YIN, Robert K. Estudo de caso: planejamento e métodos. Trad. Daniel Grassi. 2ed. Porto Alegre: Bookman, 2001. Disponível em: $<$ https://saudeglobaldotorg1.files.wordpress.com/2014/02/yinmetodologia_da_pesquisa_estudo_de_caso_yin.pdf >. Acesso em: 29 nov. 2016. 
ZAMBERLAM, Jurandir; CORSO, Giovanni; CIMADON, João Marcos; BOCCHI, Lauro. Os novos rostos da imigração no Brasil - Haitianos no Rio Grande do Sul. Porto Alegre. Solidus, 2014, p.11.

ZANATTA, Rosangela. Abordagens de ensino de cultura na aula de Português (brasileiro) para Falantes de Outras Línguas. In: FURTUSO, Viviane Bagio (Org.). Formação de professores de português para falantes de outras línguas: reflexões e contribuições. Londrina: EDUEL, 2009, p.159-181. 
APÊNDICE A - Módulo Apresentação

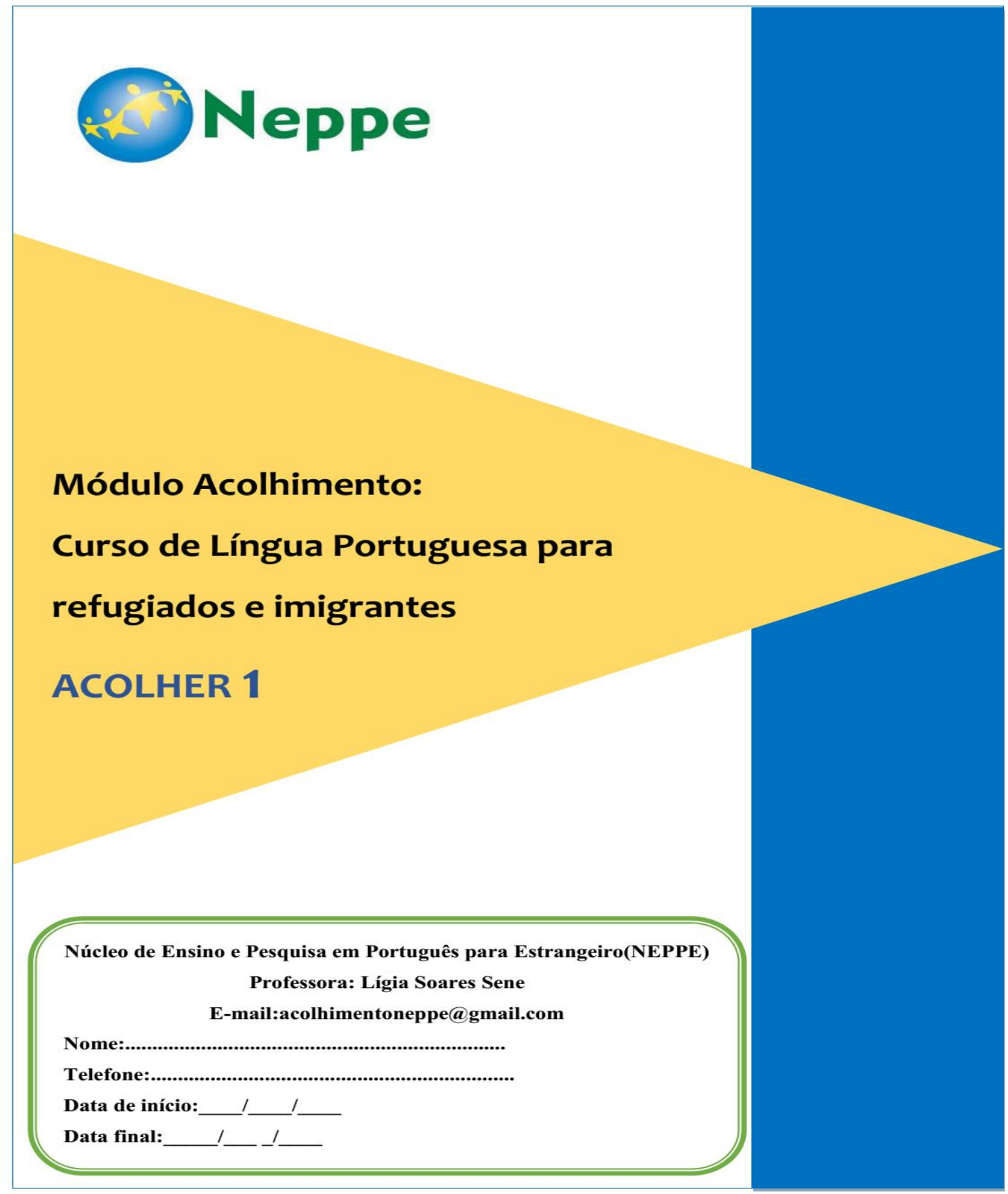




\section{APRESENTAÇÃo}

Este material didático foi produzido pelas professoras e pesquisadoras Ingrid Sinimbu Cruz e Lígia Soares Sene, com a colaboração de Mirelle Amaral e Natália Rangel. Ele é destinado ao Módulo Acolhimento: Curso de Língua Portuguesa para refugiados e imigrantes, ofertado pelo Núcleo de Ensino e Pesquisa em Português para Estrangeiros (NEPPE), da Universidade de Brasília (UnB), em parceria com o Instituto de Migrações e de Direitos Humanos (IMDH) e com o Alto Comissariado das Nações Unidas para Refugiados (ACNUR). Este curso pertence ao projeto de pesquisa PROACOLHER: Português para Estrangeiros: língua-cultura e acolhimento em contexto de migrações internacionais e refúgio, coordenado pela Professora Doutora Lúcia Maria Assunção Barbosa e tem por objetivo possibilitar gratuitamente o ensino-aprendizagem da Língua Portuguesa como Língua de acolhimento. Dessa forma, este material foi elaborado visando atender as demandas e as especificidades que esse ensino-aprendizagem apresenta. $\mathrm{O}$ material está em constante aperfeiçoamento, pois a cada realização do Módulo Acolhimento, buscamos adaptá-lo às especificidades de cada grupo.

\section{A LÍNGUA PORTUGUESA NO MUNDO}

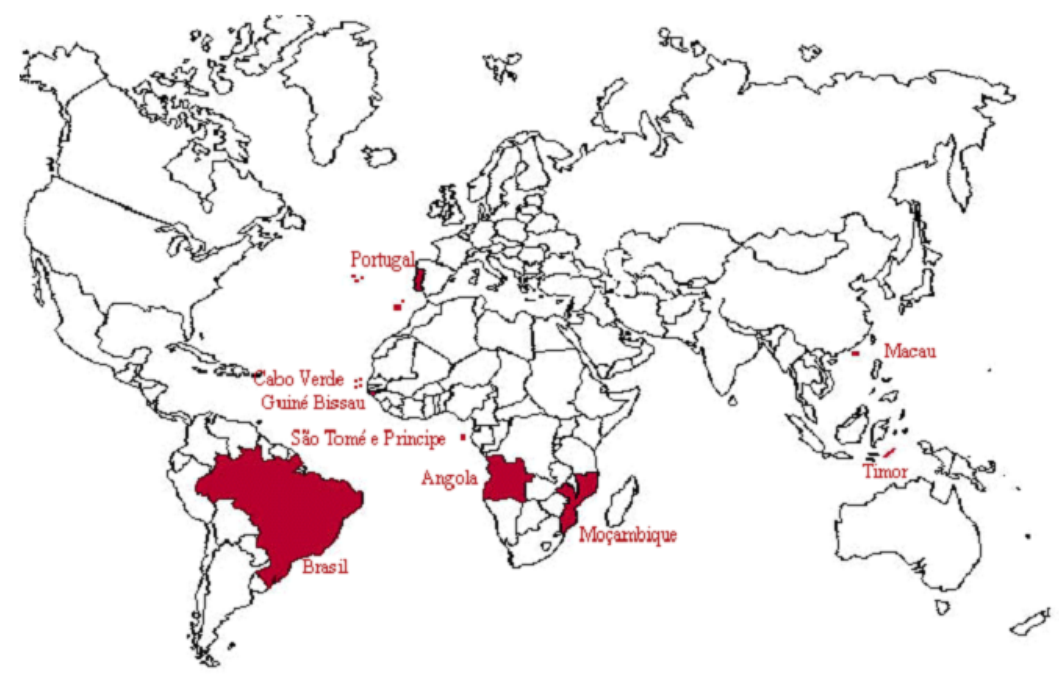

Disponível em: http://html.rincondelvago.com/estudo-historico-e-filologico-do-portugues.html

A língua portuguesa tem aproximadamente 280 milhões de falantes no mundo. Está presente nos 5 continentes. É a língua oficial em 10 países, que são: Brasil, Portugal, Moçambique, Angola, São Tomé e Príncipe, Guiné-Bissau, Guiné-Equatorial, Cabo Verde, Timor Leste e Macau. O português é a $5^{\text {a }}$ língua mais falada no mundo. 
O BRASIL - Os estados e as cidades brasileiras

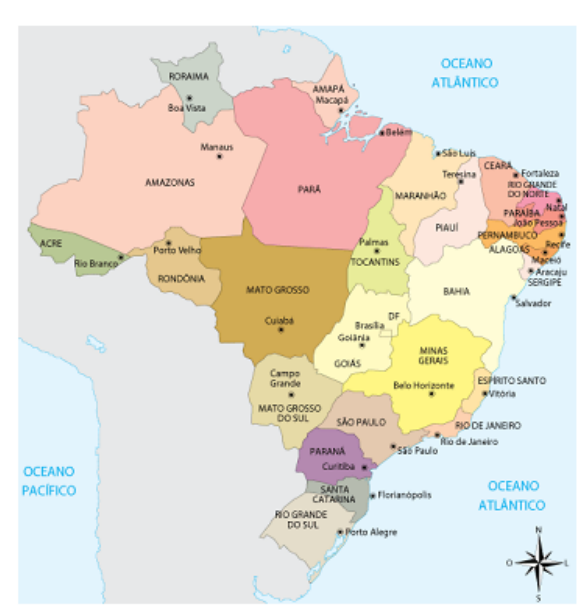

O Brasil é um país situado na América do Sul, possui cerca de 202.768.562 de habitantes (estimativa do IBGE, 2014). Ele é composto por 26 estados e um Distrito Federal, onde se encontra a capital do país, Brasília. A língua oficial do país é a Língua Portuguesa.

\section{Disponível em:}

http://revistaescola.abril.com.br/geografia/fundamentos/comofunciona-processo-criacao-novos-estados-476160.shtml

\section{O Distrito Federal e as suas regiões administrativas}

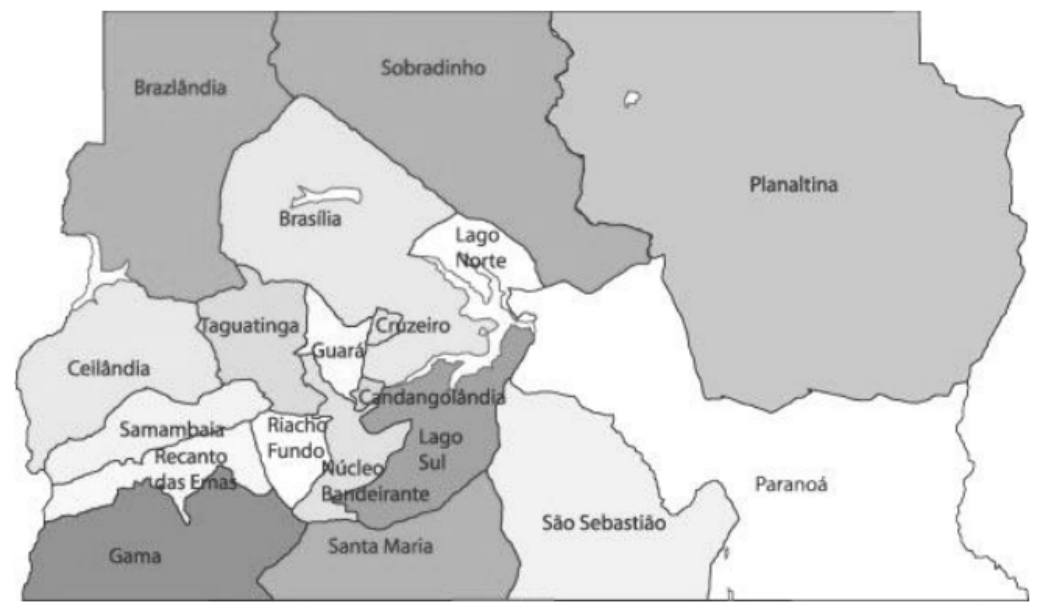

Disponivel em: http://www.brasil-turismo.com/distrito-federal/mapa-regioes.htm 
BRASÍLIA - PLANO PILOTO

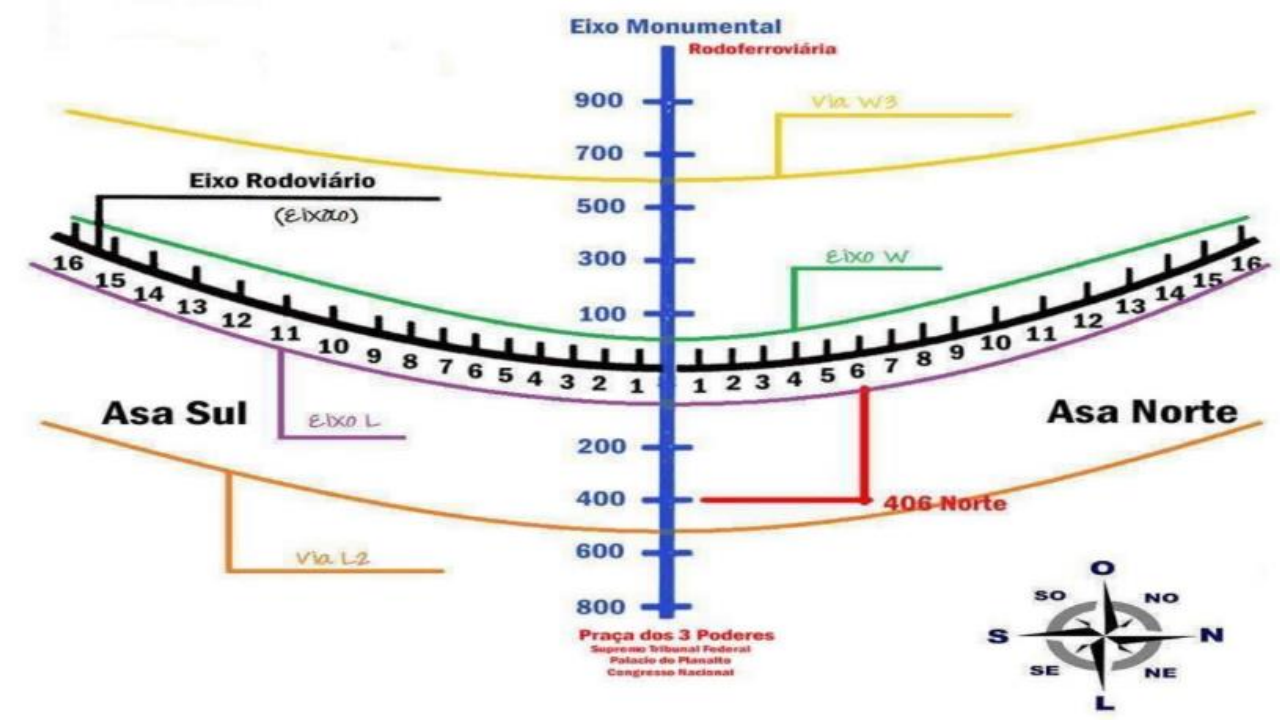

Disponivel em

https://www.facebook.com/SeturDF/photos/a.173597179362087.54077.168823163172822/956947007693763/?type=3\&theater

UNIVERSIDADE DE BRASÍLIA

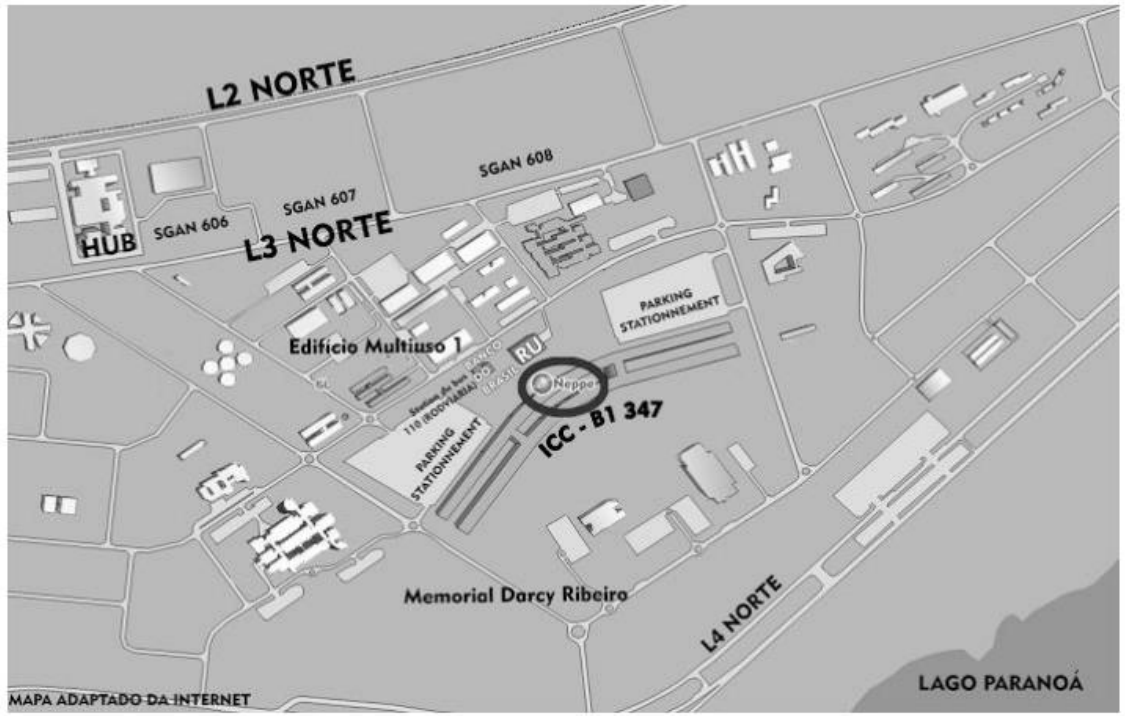




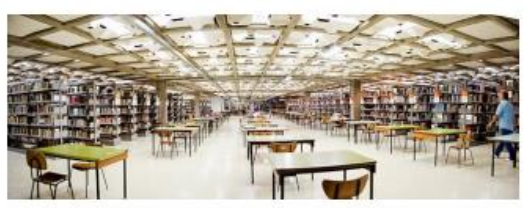

Biblioteca Central (BCE)

Horário de funcionamento:

Segunda a sexta: $07 \mathrm{~h}$ às $23 \mathrm{~h} 45$

Sábados, domingos e feriados: $08 \mathrm{~h}$ às $17 \mathrm{~h} 45$

Todos têm direito a acesso a biblioteca.

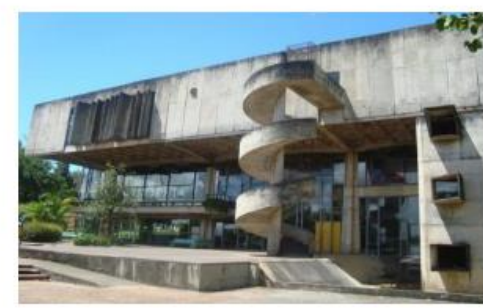

Restaurante Universitário

Horário de funcionamento:

Segunda a Sábado:

Café da manhã: $07 \mathrm{~h}$ às $9 \mathrm{~h}$ (valor: 7,50 )

Almoço: $11 \mathrm{~h}$ às $14 \mathrm{~h} 30$ (valor: 12,50 )

Jantar: $17 \mathrm{~h}$ às $19 \mathrm{~h} 30$ (valor: 12,50 )

\section{SAUDAÇÕES BRASILEIRAS}
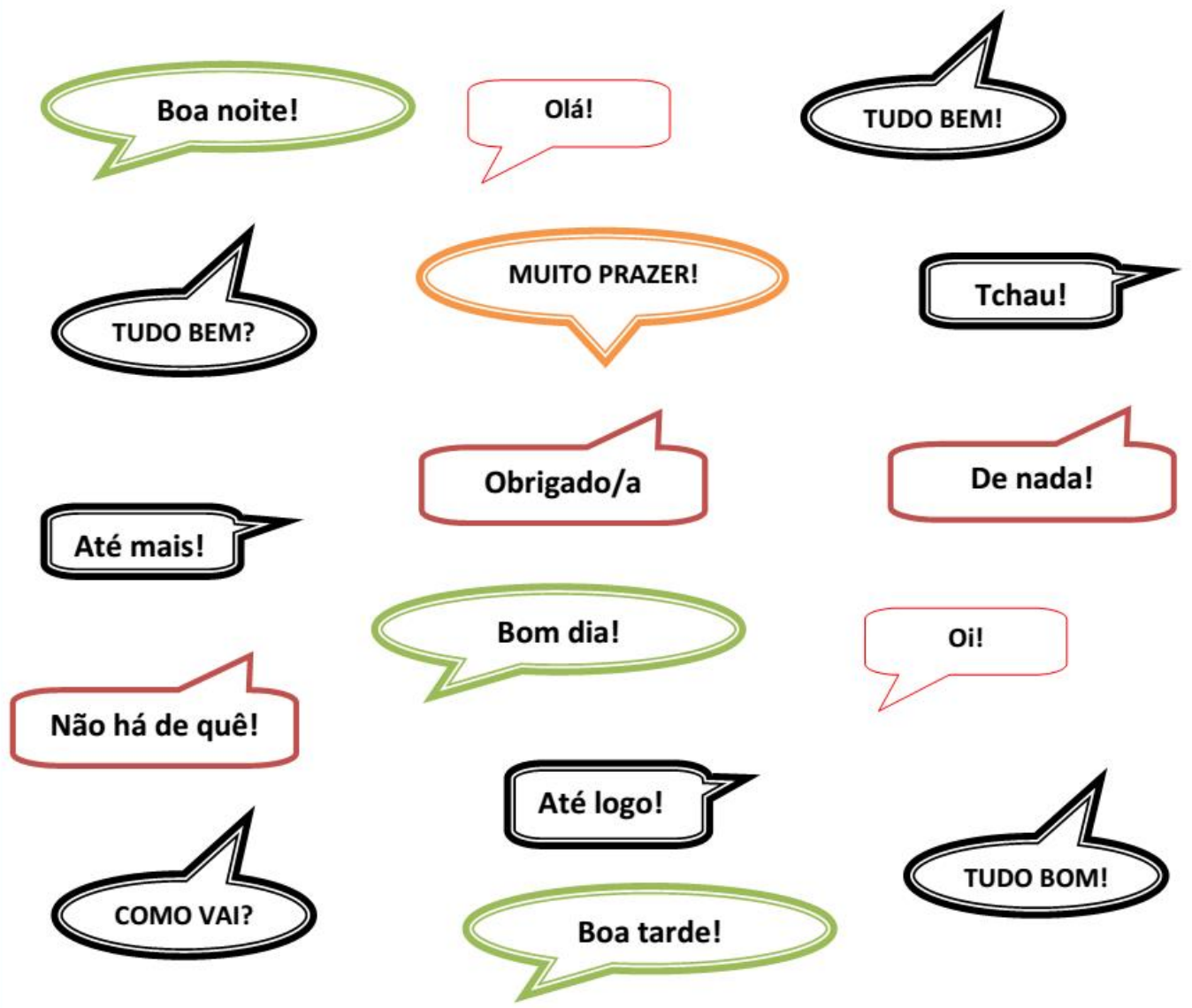
O DIA

Oh

$12 \mathrm{~h}$

$18 \mathrm{~h}$

24h

BOM DIA!

BOA TARDE!

BOA NOITE!

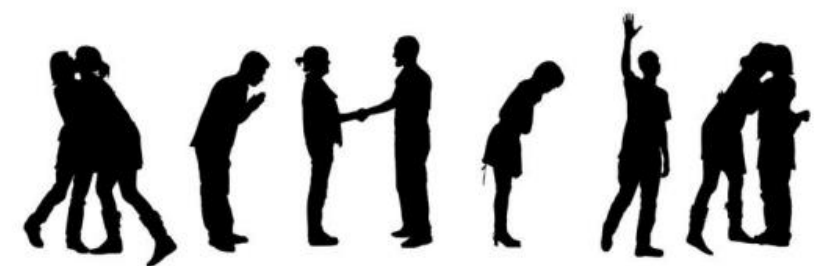

Disponivel em: http://mademoisellevovage.com.br/blog/wp-content/uploads/2011/09/diferentes cumprimentos.jpg

CUMPRIMENTOS BRASILEIROS

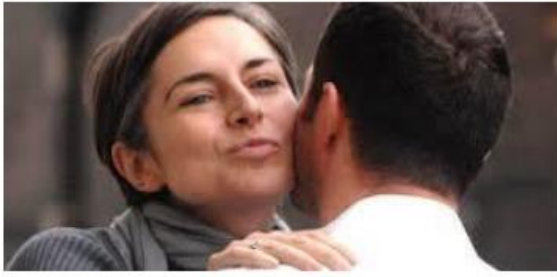

Beijo no rosto

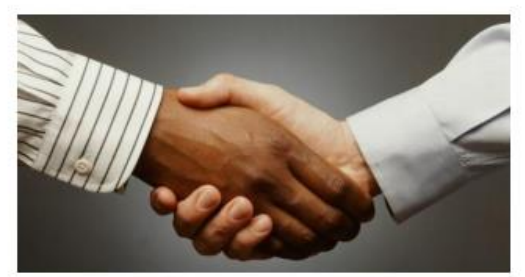

Aperto de mão

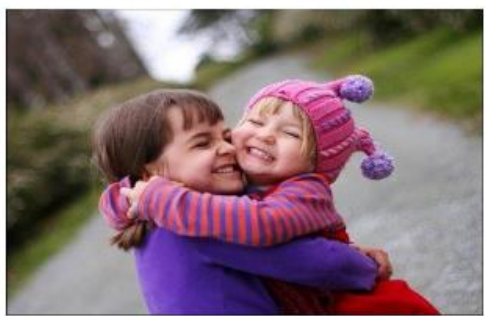

Abraço 


\section{EXPRESSÕES ÚTEIS}

\section{SAUDAÇÃO FORMAL}

- Bom dia

- Boa tarde

- Boa noite

- Prazer em conhecer.

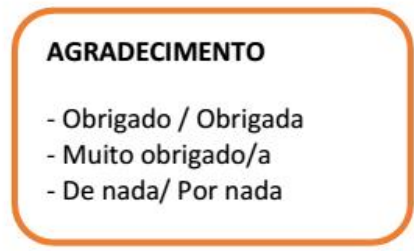

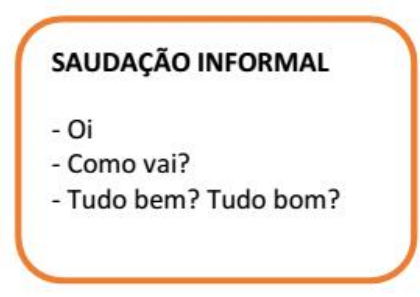
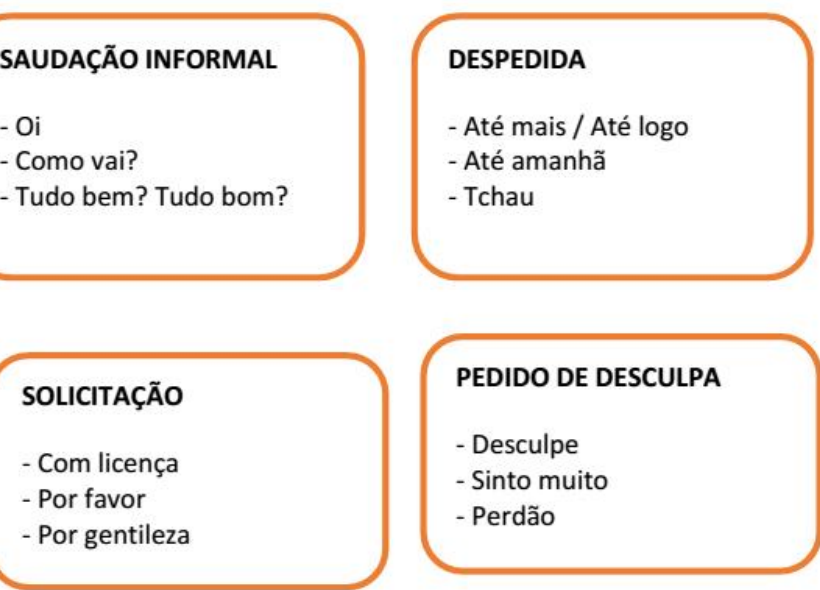

PEDIDO DE DESCULPA

- Desculpe

- Sinto muito

- Perdão

EM SALA DE AULA
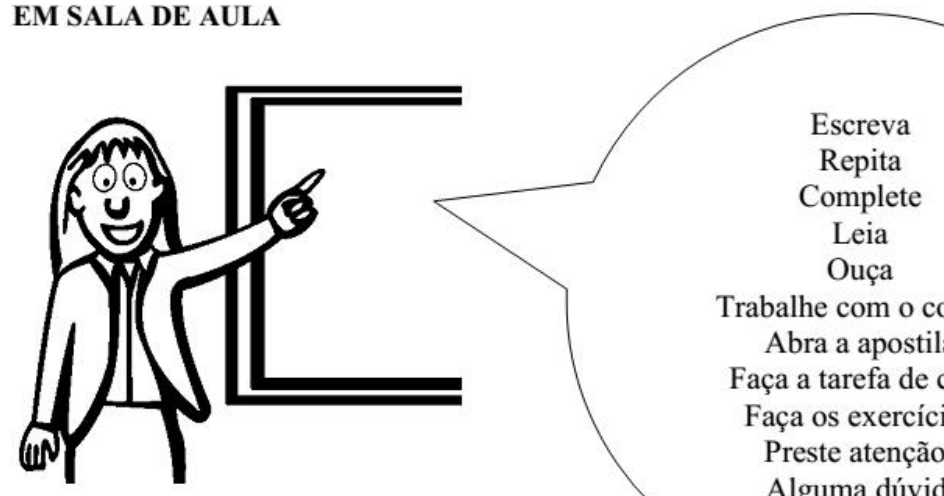

Trabalhe com o colega Abra a apostila

Faça a tarefa de casa

Faça os exercícios

Preste atenção!

Alguma dúvida?

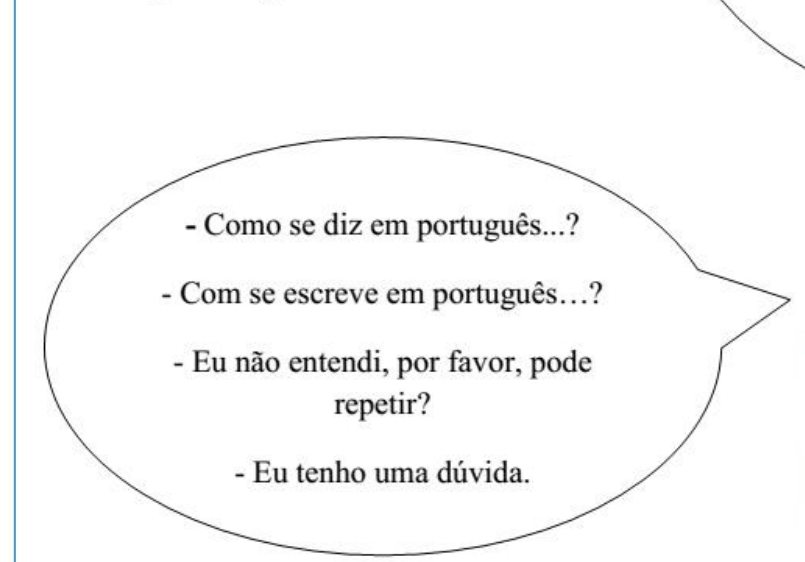

Alcoma dưvida?

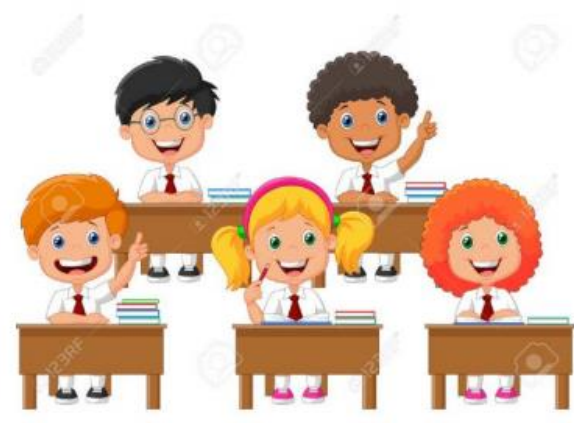

Disponivel em : http://thumbs.dreamstime.com/z/desenhos-animados-dos-alunos-na-sala-de-aula-na-li\% $\%$ C3\%A7\%C3\%A30-50839842.jpg 


\section{PRATICANDO}

1. Relacione as imagens com as frases:

(1) Com licença, posso entrar?

(2) Por favor, posso ir ao banheiro?

(3) Eu tenho uma dúvida?

(4) Por favor, posso ir beber água?

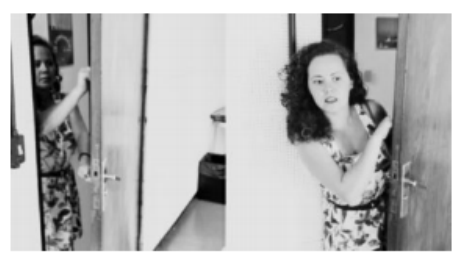

Frase

Frase
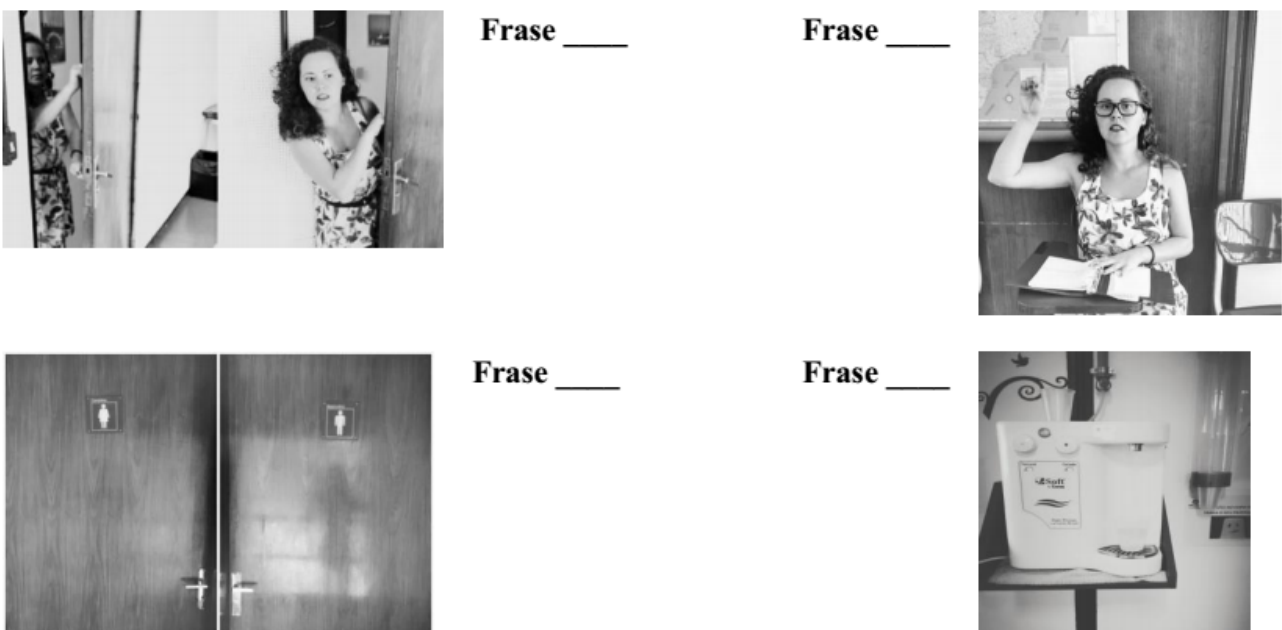

Frase

Frase

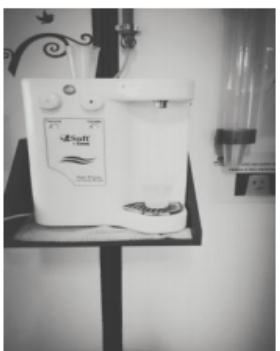

2. Complete o quadro com as expressões usadas para cada situação:

\begin{tabular}{|l|l|l|l|l|l|}
\hline $\begin{array}{c}\text { SAUDAÇÃO } \\
\text { FORMAL }\end{array}$ & $\begin{array}{c}\text { SAUDAÇÃO } \\
\text { INFORMAL }\end{array}$ & DESPEDIDA & AGRADECIMENTO & SOLICITAÇÃO & $\begin{array}{c}\text { PEDIDO DE } \\
\text { DESCULPA }\end{array}$ \\
\hline & & & & & \\
\hline & & & & & \\
\hline & & & & & \\
\hline & & & & & \\
\hline
\end{tabular}


ALFABETO DA LÍNGUA PORTUGUESA

\begin{tabular}{|c|c|c|c|c|c|c|}
\hline $\begin{array}{c}\mathbf{A} \\
\text { (a) }\end{array}$ & $\begin{array}{c}\text { B } \\
\text { (bê) }\end{array}$ & $\begin{array}{c}\mathrm{C} \\
\text { (cê) }\end{array}$ & $\begin{array}{c}\text { D } \\
\text { (dê) }\end{array}$ & $\begin{array}{c}\mathbf{E} \\
\text { (ê/é) }\end{array}$ & $\begin{array}{c}F \\
\text { (éfe) }\end{array}$ & $\underset{\text { (gê) }}{G}$ \\
\hline $\begin{array}{c}\text { H } \\
\text { (agá) }\end{array}$ & $\begin{array}{l}\mathbf{I} \\
\text { (i) }\end{array}$ & $\begin{array}{c}\mathbf{J} \\
\text { (jóta) }\end{array}$ & $\underset{\text { (ká) }}{\mathbf{K}}$ & $\begin{array}{c}\mathbf{L} \\
\text { (éle) }\end{array}$ & $\begin{array}{c}\mathbf{M} \\
(\mathrm{eme})\end{array}$ & $\begin{array}{c}\mathbf{N} \\
\text { (ene) }\end{array}$ \\
\hline $\begin{array}{c}\mathbf{O} \\
(\hat{\mathbf{o}} / \mathbf{0})\end{array}$ & $\underset{\text { (pê) }}{\mathbf{P}}$ & $\begin{array}{c}\mathbf{Q} \\
\text { (quê) }\end{array}$ & $\begin{array}{c}\mathbf{R} \\
\text { (érre) }\end{array}$ & $\begin{array}{c}\mathbf{S} \\
\text { (ésse) }\end{array}$ & $\begin{array}{c}\mathbf{T} \\
\text { (tê) }\end{array}$ & $\begin{array}{c}\mathbf{U} \\
(\mathrm{u})\end{array}$ \\
\hline$\underset{\text { (vê) }}{V}$ & $\begin{array}{c}\mathbf{W} \\
\text { (dáblio) }\end{array}$ & $\underset{\text { (xis) }}{\mathbf{X}}$ & $\begin{array}{c}\mathbf{Y} \\
\text { (ipsilon) }\end{array}$ & $\underset{\text { (zê) }}{\mathbf{Z}}$ & & \\
\hline
\end{tabular}

Vogais

\begin{tabular}{|c|c|c|c|c|}
\hline $\begin{array}{c}A \\
(\mathbf{a})\end{array}$ & $\begin{array}{c}\mathbf{E} \\
\text { (ê/é) }\end{array}$ & $\begin{array}{c}\mathbf{I} \\
\text { (i) }\end{array}$ & $\begin{array}{c}\mathbf{O} \\
(\hat{\mathbf{o}} / \mathbf{o})\end{array}$ & $\begin{array}{c}\mathbf{U} \\
\text { (u) }\end{array}$ \\
\hline
\end{tabular}

\section{Dígrafos:}

Ch: chave, chuva, chorar, chá.

Lh : folha, joelho, olho, acolher.

Nh: manhã, tenho, sonho, dinheiro.

Rr: carro, arroz, barriga, churrasco.

Ss: compromisso, interesse, profissão, esse.

Gu: água, guerra, Guará, guichê.

Acentos:
- agudo - ÁGUA, CAFÉ
til - PÃO, NÃO
^ circunflexo - ÔNIBUS, MÊS
v grave - Às VEZES, À NOITE 
152

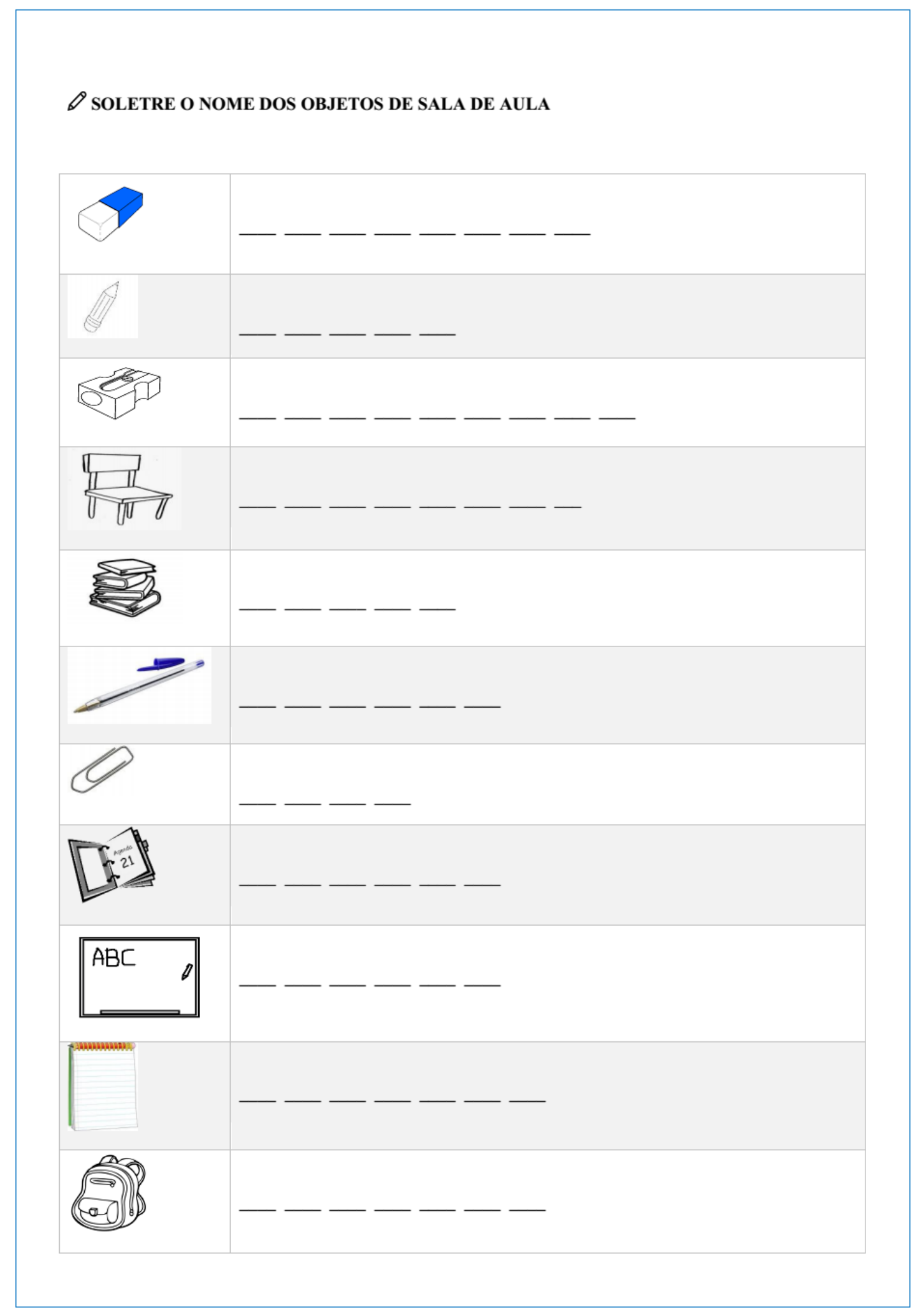




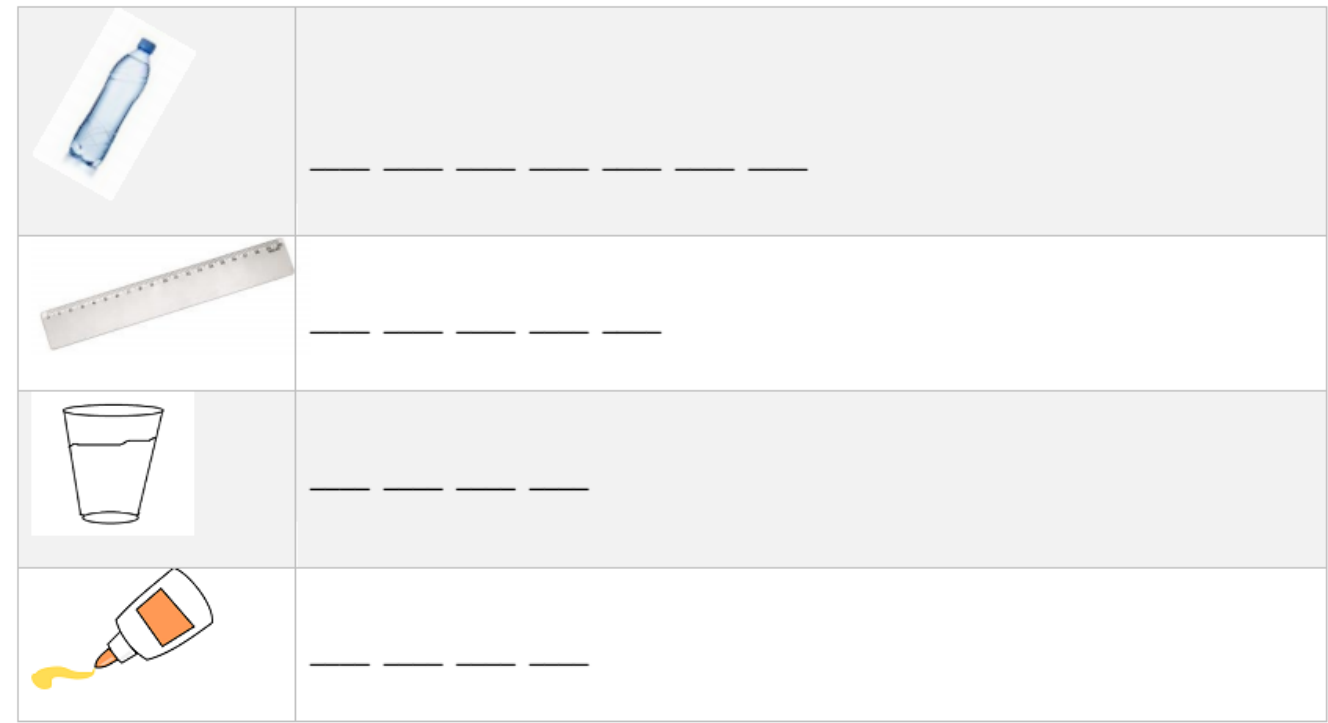

\section{দ»)) MÚSICA}

\section{Abecedário da Xuxa}

Xuxa

A de amor

B de baixinho

C de coração

D de docinho

E de escola

$F$ de feijão

$\mathrm{G}$ de gente

$\mathrm{H}$ de humano

I de igualdade

J, juventude

$\mathrm{L}$, liberdade

$\mathrm{M}$, molecagem

$\mathrm{N}$, natureza

$\mathrm{O}$, obrigado

$\mathrm{P}$, proteção

$\mathrm{Q}$ de quero-quero

$\mathrm{R}$ de riacho

\section{S, saudade}

T de terra

$\mathrm{U}$ de universo

$\mathrm{V}$ de vitória

$\mathrm{X}$, o que que é?

É Xuxa!

E Z é zum-zum-zum-zum-zum

Vamos cantar

Vamos brincar

Alegria pra valer

O abecedário da Xuxa

Vamos aprender

Vamos cantar

Vamos brincar

Alegria pra valer

$\mathrm{O}$ abecedário da Xuxa

Vamos aprender 
Leia o diálogo abaixo:

\section{EXERCÍCIOS}

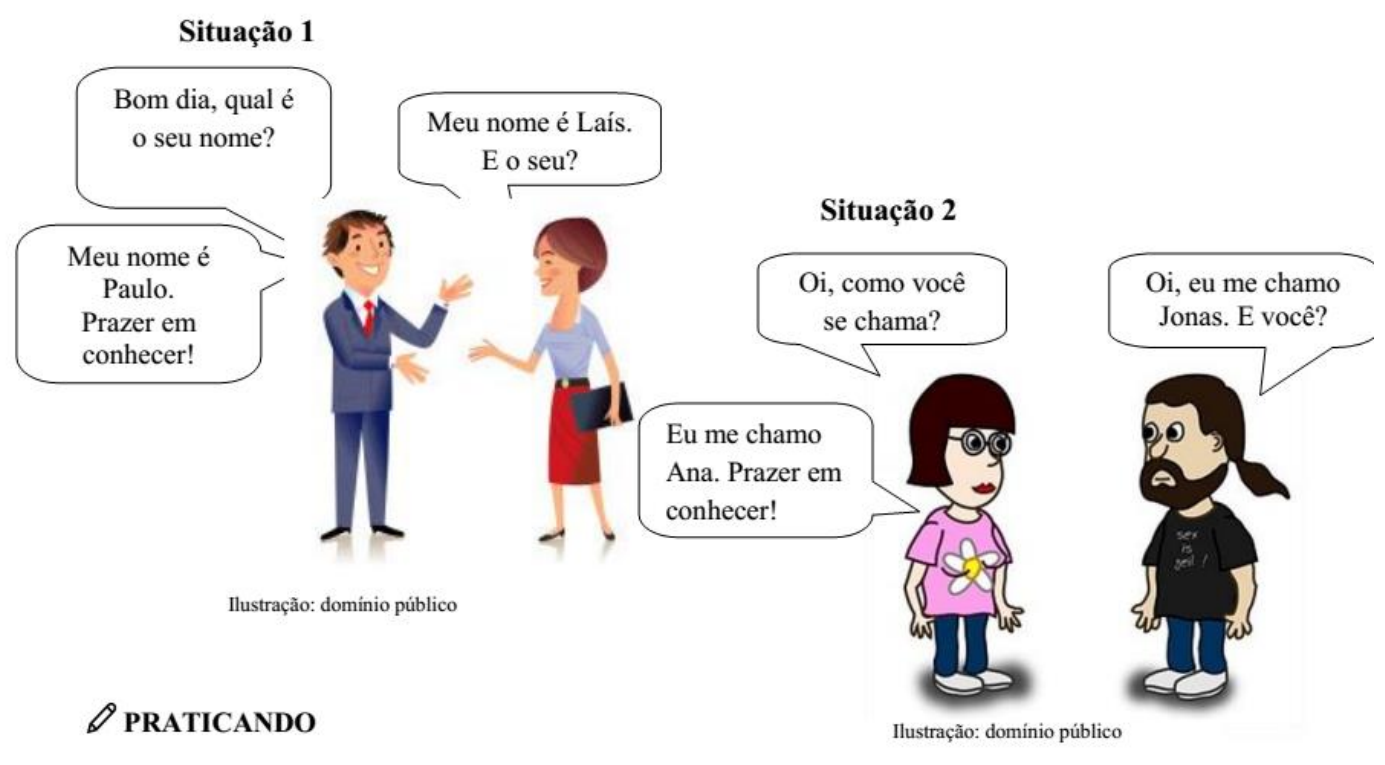

1. Complete os espações com as palavras adequadas:

\section{A. Qual é o seu nome?}

Aluno 1: Oi, tudo bem?

Aluno 2: Oi,

QUAL?

Aluno 1: Qual é o seu nome?

Aluno 2: E o seu?

Aluno 1: Meu nome é Muito

Aluno 2: O prazer é meu!

Aluno 1: Tenha um bom dia!

Aluno 2: Obrigad ( )

Aluno 1:

\section{B. Como você se chama?}

Aluno 1: Boa

Aluno 2: Boa noite.

Aluno 1: Eu me chamo E você?

\section{COMO?} Aluno 2:

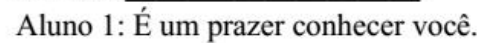

Aluno 2:

Aluno 1: Tchau

Aluno 2: 
Leia o diálogo abaixo:

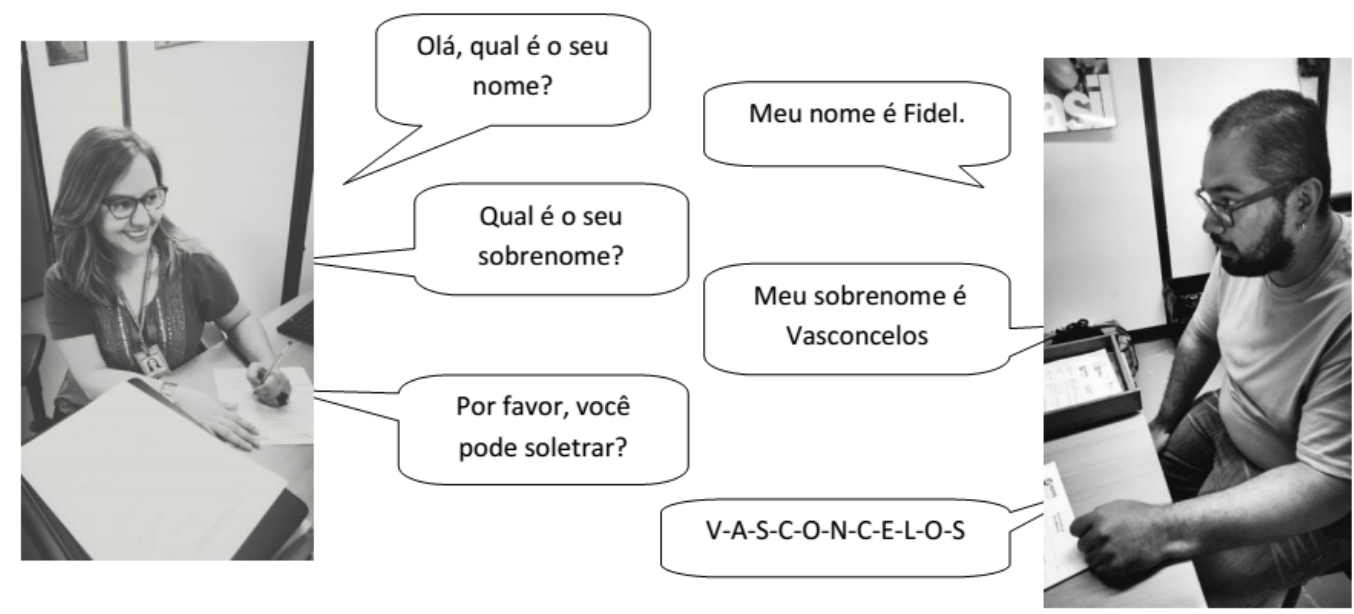

2. Agora, preencha as fichas com as informações de um colega:
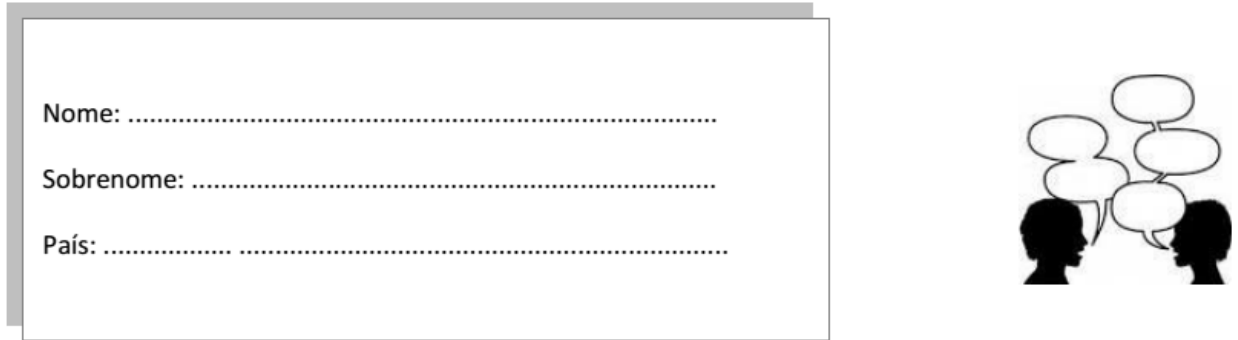

Nome:

Sobrenome:

País: 
3. Pesquise e escreva em português nomes de objetos que se iniciem com as letras do alfabeto:

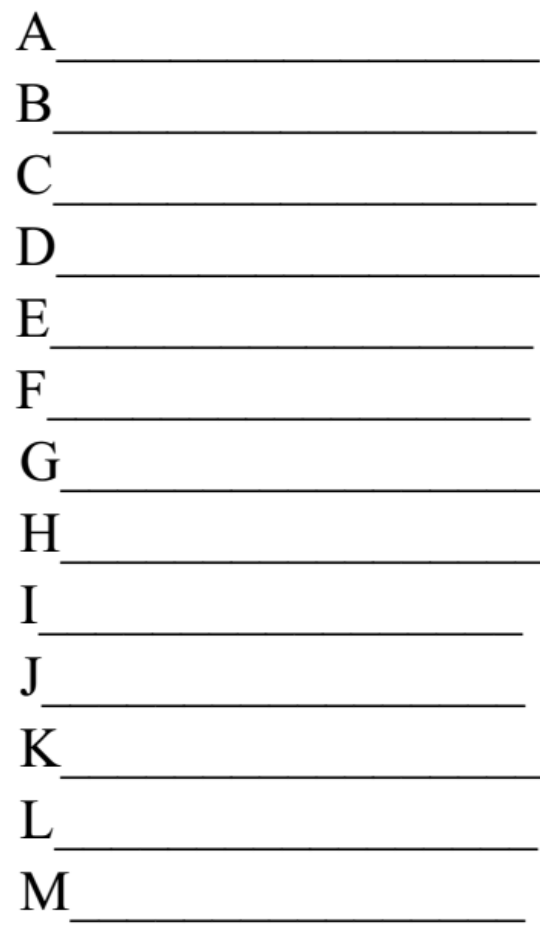

$\mathrm{N}$

$\mathrm{O}$

$\mathrm{P}$

Q

$\mathrm{R}$

$\mathrm{S}$

$\mathrm{T}$

$\mathrm{U}$

$\mathrm{V}$

W

X

Y

Z 


\begin{tabular}{|c|l|}
\hline MÓDULO & Neste módulo você aprenderá: \\
PRAZER EM CONHECER! & Apresentar-se \\
& Falar sobre você \\
& Fazer perguntas \\
& Falar sobre outra pessoa \\
Conhecer personalidades brasileiras
\end{tabular}

PRAZER EM CONHECER!

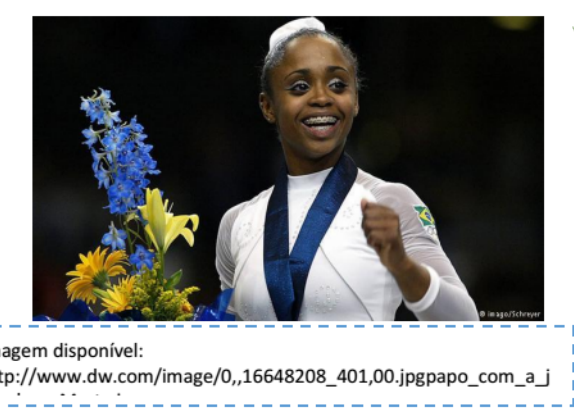

Olá, tudo bem? Meu nome é Daiane Garcia dos Santos. Eu sou brasileira e eu tenho 33 anos. Eu sou ex-ginasta brasileira. Sou solteira e moro em Porto Alegre. Muito prazer!

\section{CONHECENDO DAIANE:}

1. Qual é o seu nome?

2. De onde você é?

3. Qualé sua nacionalidade?

4. Quantos anos você tem?

5. Qual é a sua profissão?

6. Qual é o seu estado civil?

7. Onde você mora?

Para fazer perguntas:

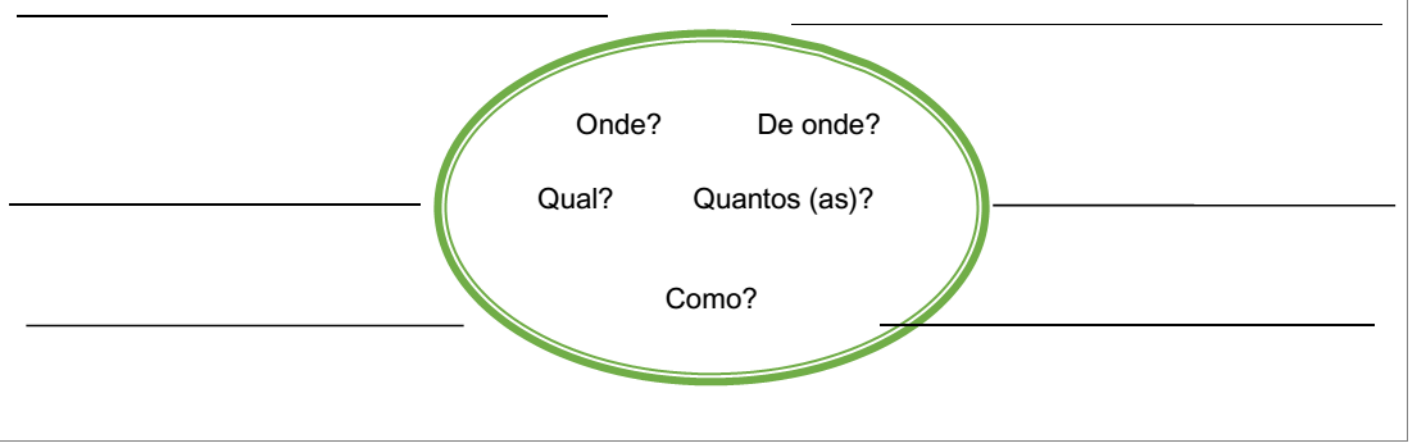


Conhecendo a língua:

\begin{tabular}{|l|c|c|}
\hline \multicolumn{3}{|c|}{ Estrutura básica da língua portuguesa } \\
\hline Sujeito & Verbo & Complemento \\
\hline Maria & é & solteira \\
\hline Ele & tem & 21 anos \\
\hline Os alunos & moram em & Brasília \\
\hline
\end{tabular}

Observe:

\begin{tabular}{|l|l|l|}
\hline \multicolumn{3}{|c|}{ Maneiras de se fazer uma pergunta } \\
\hline * Onde & você & mora? \\
\hline Você & mora & onde? \\
\hline
\end{tabular}

\section{EXERCÍCIOS}

1. Colocar as palavras na ordem adequada:

a. moramos nós Taguatinga em

b. Julia filhos 2 tem

c. do eu Paquistão sou/

d. seu o qual é nome?

e. anos têm vocês quantos?

2. Complete com as perguntas:

\begin{tabular}{|c|c|c|}
\hline 1. ONDE & ) & você gosta de fazer? \\
\hline 2. QUAL & $(\mathrm{r})$ & você se chama? \\
\hline 3. COMO & $(\quad)$ & anos você tem? \\
\hline 4. QUANTOS & $(\quad)$ & você mora? \\
\hline 5. QUAL & () & você é? \\
\hline 6. DE ONDE & $(1)$ & anos você tem? \\
\hline 7. O QUE & ) & é a sua nacionalidade? \\
\hline
\end{tabular}




\section{EXERCÍCIOS}

1. Complete com os verbos SER, TER, MORAR em sua conjugação adequada:
a) Meu nome_ João. Eu__ Iraquiano. Eu____ em Taguatinga. Eu casado. $\mathrm{Eu}$ 3 filhas. Eu engenheiro.

b) Seu nome

Ela português.

c) Eles Norte.Eles Eles brasileiros. Eles solteiros. Eles pedreiros.
Ana.Ela solteira. Ela Haitiana. Ela

3 irmãos. Ela no Varjão. estudande de

\section{Responda as perguntas abaixo:}

1. Qual é o seu nome? /

Como você se chama?

2. De onde você é?

3. Quantos anos você tem?

4. Qual é o seu estado civil?

3. Escreva sobre você:

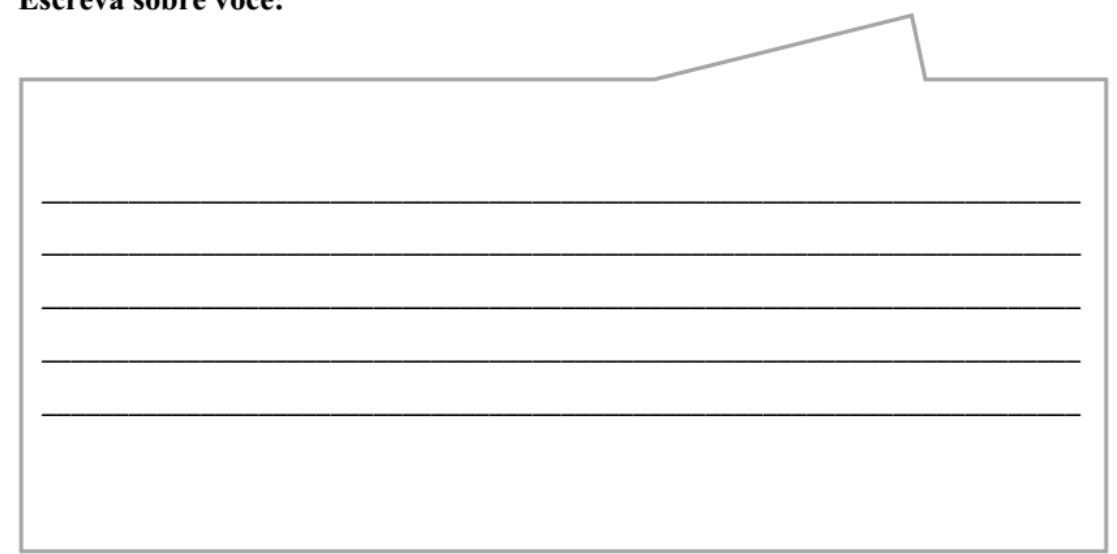




\section{MUITO PRAZER!}

Bom dia! Eu me chamo Chico Buarque. Eu sou do Brasil, eu sou brasileiro e eu tenho 72 anos. Eu sou cantor e escritor. Eu sou divorciado, tenho 3 filhas. Eu moro no Rio de Janeiro. Muito prazer!

CONHECENDO CHICO BUARQUE:

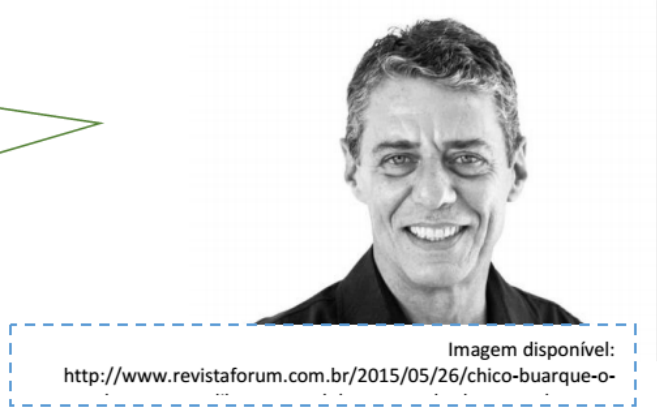

1. Qual é o seu nome?

2. De onde você é?

3. Qualé sua nacionalidade?

4. Quantos anos você tem?

5. Qual é a sua profissão?

6. Qual é o seu estado civil?

7. Onde você mora?

Qual é o seu estado civil?

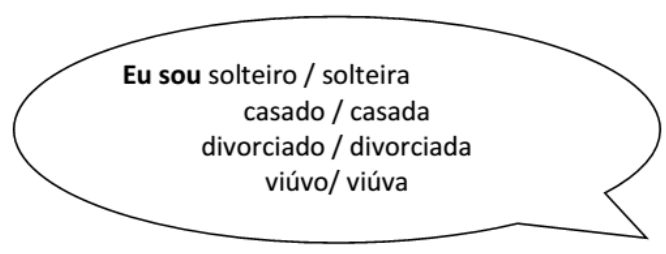




\section{Eu não sou da sua rua}

Eu não da sua rua,

Não sou o seu vizinho.

$\mathrm{Eu}$ muito longe, sozinho. aqui de passagem.

Eu não sou da sua rua,

Eu não a sua língua,

Minha vida diferente da sua.

Estou aqui de passagem.

Esse mundo não meu

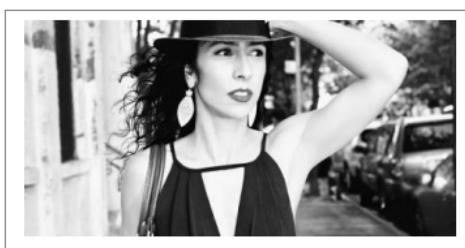

Olá, eu sou Marisa Monte. Eu sou brasileira.

Eu sou cantora. Sejam bem-vindas e bem vindos ao Brasil!

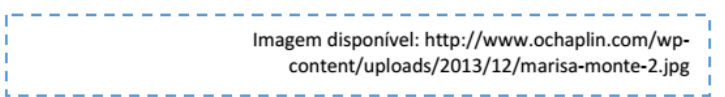

Esse mundo não é seu

Escreva uma frase com os vocabulários:

Rua:

Longe:

Sozinho

Mundo:

Passagem:

Conhecendo a língua:

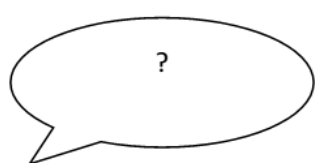

- INTERROGAÇÃO<< ? >>

- Você é brasileiro?

- Você fala inglês?

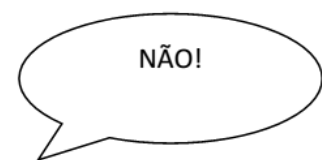

- NEGAÇÃO <<não +..........>

- Eu não sou brasileiro.

- Eu não falo inglês.

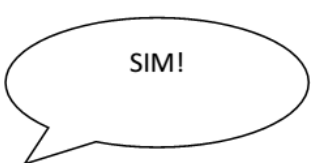

\section{- AFIRMAÇão}

- Eu sou estrangeiro.

- Eu falo francês.

\section{Passe as frases para a negativa:}

a) Eu gosto de chocolate.

b) Você vai ao teatro?

c) Eu estou bem. 
DE ONDE VOCÊ É?

- Oi, tudo bom?

$\diamond \quad$ Tudo bom!

- Você não é brasileiro, não é?

$\diamond \quad$ Não, não sou.

- De onde você é?

$\checkmark$ Eu sou do Haiti, sou haitiano. E você, de onde é?

Eu sou do Brasil (país)

Eu sou brasileiro (nacionalidade)

- Eu sou da Colômbia, mas moro no Brasil há mais de 1 ano.

Veja:

\section{PAÍS}

De onde você é? Eu sou de Gana.

Eu sou do Congo.

Eu sou da Bolívia.

\section{NACIONALIDADE}

Qual é a sua nacionalidade? Eu sou ganense.

Eu sou congolense.

Eu sou boliviano/a. 
QUAL É A SUA NACIONALIDADE?

\begin{tabular}{|c|c|c|}
\hline \multirow{4}{*}{$0 \rightarrow A$} & PAÍS & NACIONALIDADE \\
\hline & O Brasil & Ele é brasileiro / Ela é brasileira \\
\hline & A Síria & Ele é sírio / Ela é síria \\
\hline & O Egito & Ele é egípcio / Ela é egípcia \\
\hline
\end{tabular}

\begin{tabular}{|l|l|l|}
\hline \multirow{3}{*}{ ANO $\rightarrow$ ANA } & \multicolumn{1}{|c|}{ PAÍS } & NACIONALIDADE \\
\hline & A Colômbia & Ele é colombiano / Ela é colombiana \\
\cline { 1 - 3 } & O Haiti & Ele é haitiano / Ela é haitiana \\
\cline { 2 - 3 } & A Angola & Ele é angolano / Ela é angolana
\end{tabular}

\begin{tabular}{|c|c|c|}
\hline \multirow{4}{*}{ ÊS $\rightarrow$ ESA } & PAÍS & NACIONALIDADE \\
\hline & O Paquistão & Ele é paquistanês / Ela é paquistanesa \\
\hline & O Congo & Ele é congolês / Ela é congolesa \\
\hline & O Sudão & Ele é sudanês / Ela é sudanesa \\
\hline
\end{tabular}

\begin{tabular}{|l|l|l|}
\hline \multirow{2}{*}{ ENSE $\rightarrow$ ENSE } & \multicolumn{1}{|c|}{ PAÍS } & NACIONALIDADE \\
\cline { 1 - 2 } & Gana & Ele é ganense / Ela é ganense \\
\cline { 1 - 2 } & Canadá & Ele é canadense / Ela é canadense \\
\hline * A Alemanha - Ele é alemão / Ela é alemã.
\end{tabular}

A Espanha - Ele é espanhol / Ela é espanhola.

CONTINENTES

1ำÁsia 4은 Antártida (Antártica)

20 América 5 Europa

3ㅇ.frica 60 Oceania 


\section{EXERCÍCIOS}

1. Preencha o quadro com o país, a nacionalidade e a língua:

\begin{tabular}{|c|c|c|}
\hline Exemplo: & Sobre você... & Sobre seu/sua colega... \\
\hline Eu sou do Brasil & 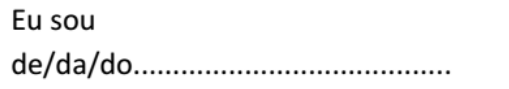 & $\begin{array}{l}\text { Ele/Ela é } \\
\text { de/da/do................................... }\end{array}$ \\
\hline Eu sou brasileira & 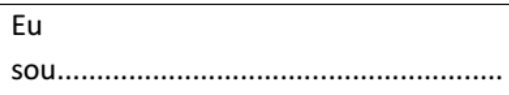 & $\begin{array}{l}\text { Ele/Ela } \\
\text { é................................................ }\end{array}$ \\
\hline Eu falo português & 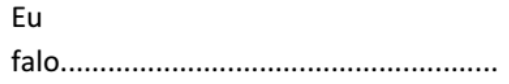 & 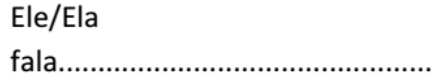 \\
\hline
\end{tabular}

\section{Complete com as nacionalidades de acordo com o país:}

- Com licença, vocês são (Brasil)?

- Não, nós não somos. Eu sou (Síria)

- E seus amigos?

- Ele é (Paquistão), ele é (Gana) e elas são (Haiti).

3. Forme frases com as palavras abaixo:

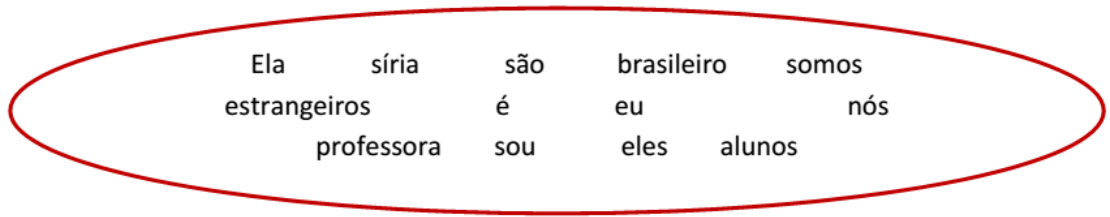

2.

3.

4. 
4. Relacione as perguntas com as respostas certas:

\begin{tabular}{|l|l|}
\hline 1. Qual é o seu nome? & $($ ) Eles são da República Democrática do Congo \\
\hline 2. De onde eles são? & $($ ) Eu sou enfermeiro \\
\hline 3. Quantos anos ela tem? & $($ ) Eles têm um filho e uma filha \\
\hline 4. Onde você mora? & $($ ) Nós moramos em Santa Maria \\
\hline 5. Qual é seu estado civil? & $($ ) Meu nome é Jean Filipe \\
\hline 6. Quantos filhos eles têm? & $($ ) Eu estou noiva há 2 anos \\
\hline 7. Onde vocês moram? & $($ ) Eu moro no Varjão \\
\hline 8. Qual é a sua profissão? & $($ ) Ela tem 24 anos \\
\hline
\end{tabular}

5. Quais são as cores da bandeira do Brasil?

\begin{tabular}{l|} 
CORES \\
Verde \\
Turquesa \\
Azul \\
Roxa \\
Violeta \\
Rosa \\
Vermelha \\
Laranja \\
Amarela \\
Bege \\
Branca \\
Prata \\
Cinza \\
Preta \\
Marrom
\end{tabular}

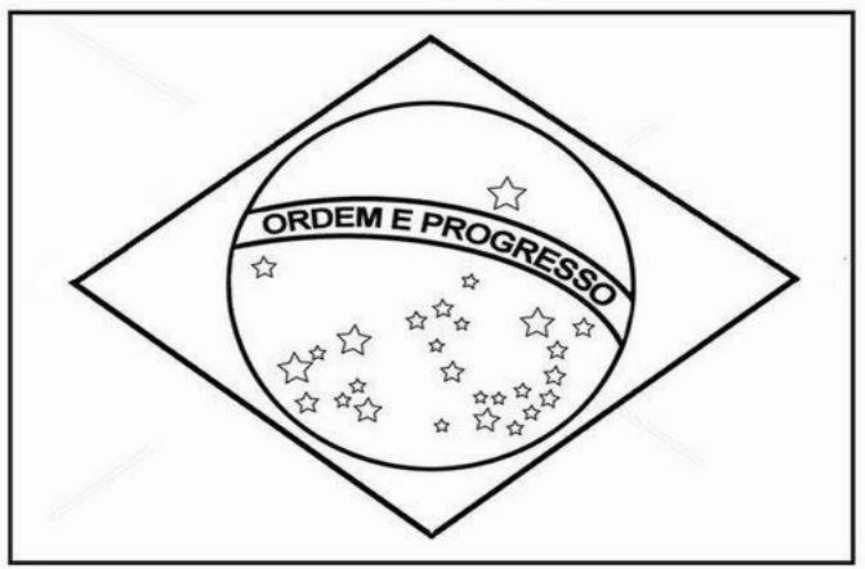

6. Quais são as cores da bandeira do seu país?

7. Desenhe a bandeira do seu país: 


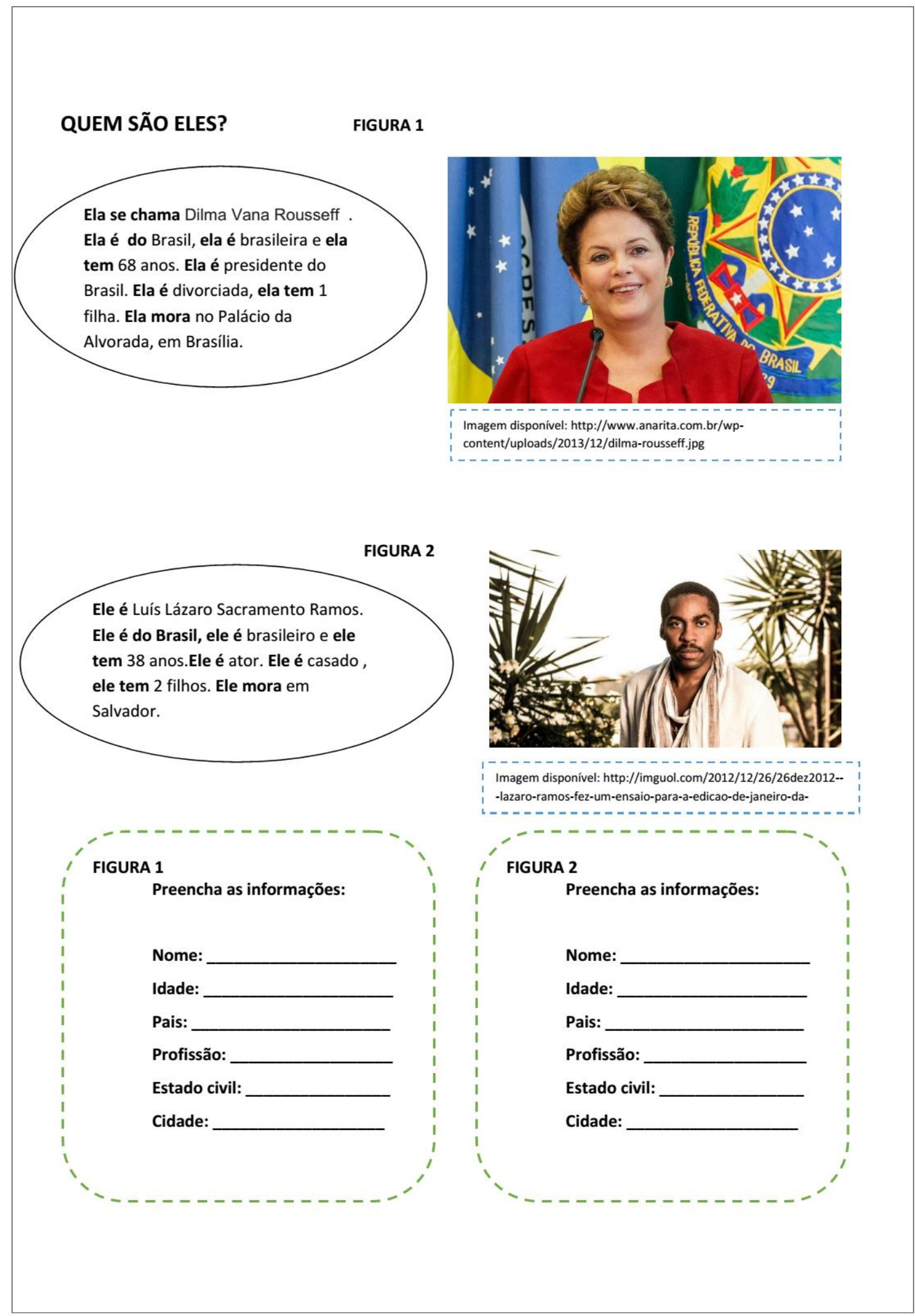




\section{Qual é a sua profissão?}

- Qual é a sua profissão?

- Eu sou estudante. E você o que faz?

- Eu sou cozinheiro.

\section{Outras profissões}

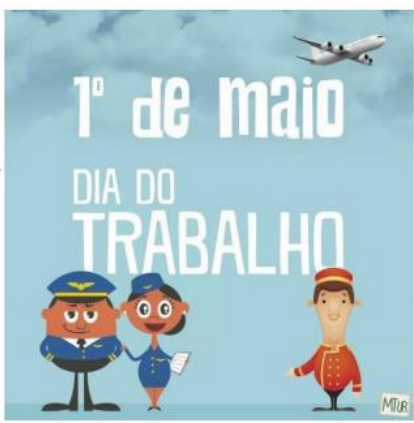

No Brasil, o Dia do Trabalho é comemorado no dia 10 de

maio, e é feriado nacional.

\begin{tabular}{|c|c|}
\hline Masculino & Feminino \\
\hline O professor & A professora \\
\hline O secretário & A secretária \\
\hline O estudante & A estudante \\
\hline O jornalista & A jornalista \\
\hline
\end{tabular}

Artigos definidos e indefinidos

\begin{tabular}{l|l|l} 
& Singular & Plural \\
\hline \multirow{2}{*}{ Masculino } & O, um & \\
\cline { 2 - 3 } & & Os, uns \\
\hline Feminino & A, uma & As, umas \\
\hline
\end{tabular}




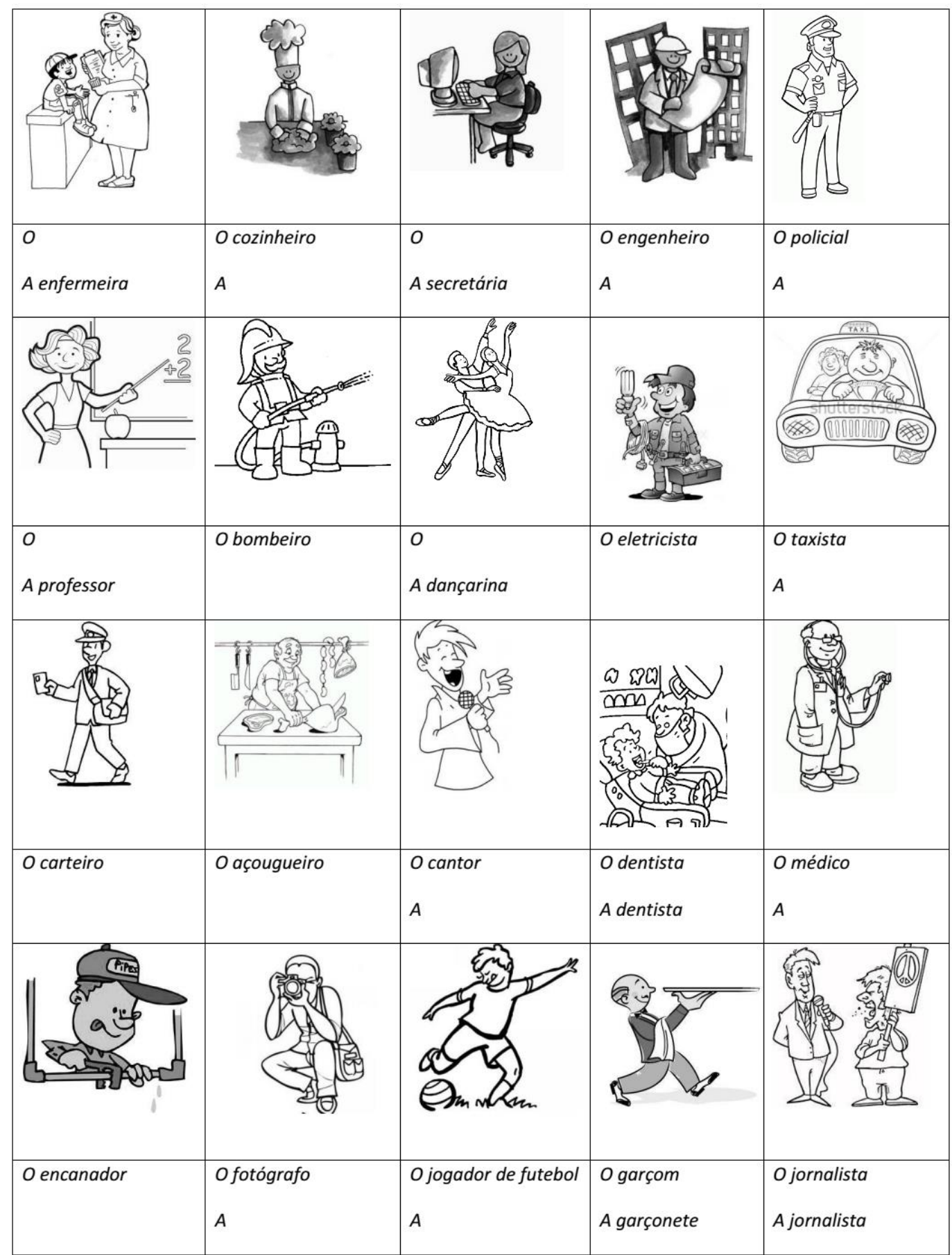




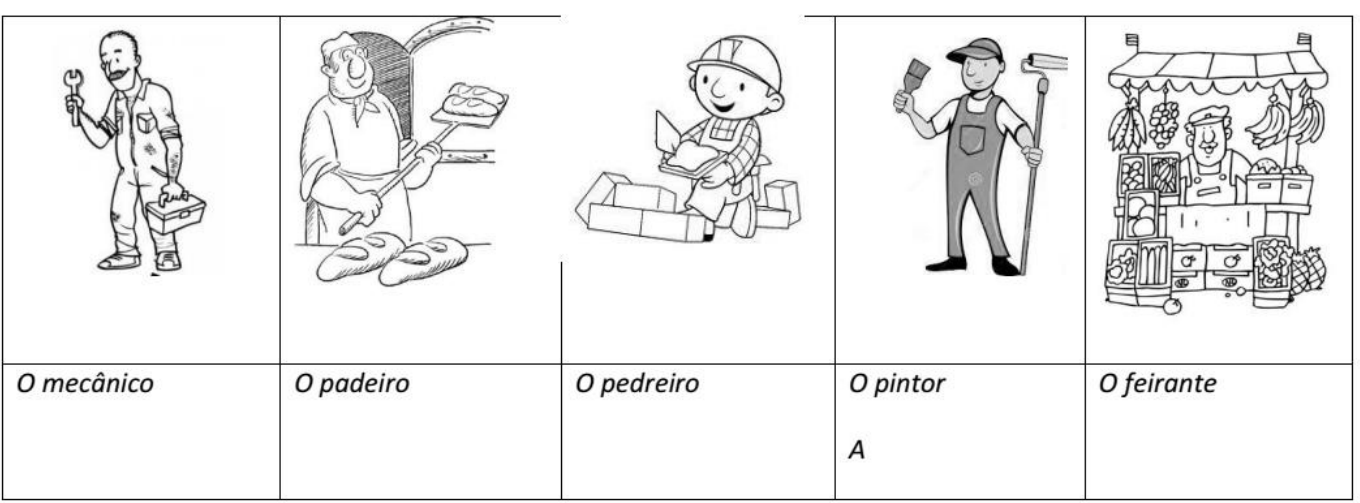

Ligue as profissões com suas respectivas funções:
1. jardineiro
( ) conserta carros e motos
2. vendedora
(1) cuida das plantas
3. mecânico
( ) defende direitos
4. enfermeiro
( ) serve as mesas
5. advogada
( ) corta cabelo
6. auxiliar de cozinha
( ) limpa
7. cabeleireira
( ) ajuda na cozinha
8. motorista de ônibus
( ) cuida das pessoas
9. faxineira
( ) dirige o ônibus
10. Garçom
( ) vende produtos

\section{Reponda:}

1. Qual é a sua profissão? O que você faz?

2. Quais são as profissões mais comuns no seu país
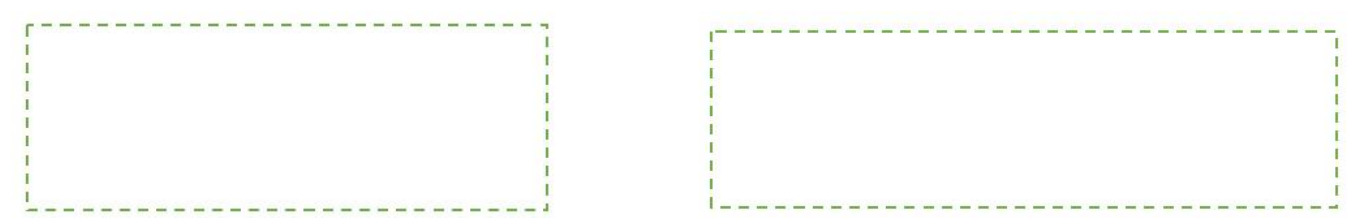


\section{EXERCÍCIOS}

1. Faça as perguntas do quadro para um colega:

5. Qual é o seu nome?/

Como você se chama?

6. De onde você é?

7. Quantos anos você tem?

8. Qual é o seu estado civil?

9. O que você faz?

2. Escreva sobre seu colega:

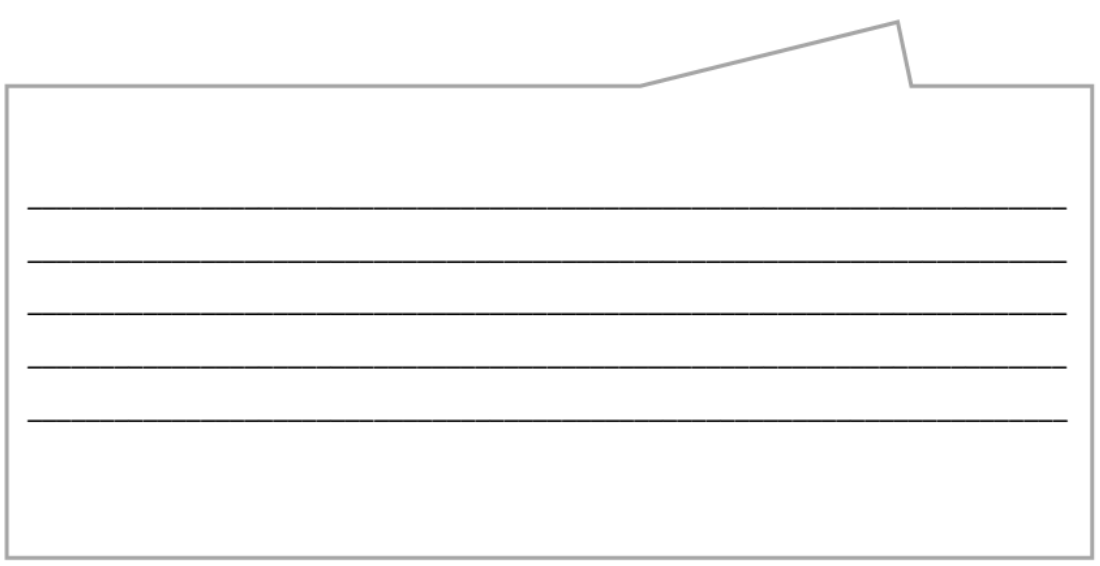




\section{TAREFA AVALIATIVA- Entregar para a professora}

\section{Leia as informações}

Nome: Edson Arantes do Nascimento

Apelido: Pelé

Idade: 76 anos

Pais: Brasil

Profissão: Jogador de Futebol

Estado civil: Casado

Endereço: Minas Gerais

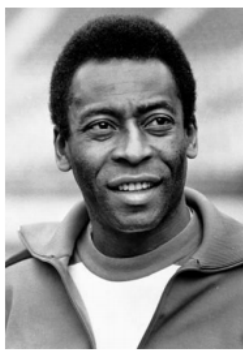

Elabore um texto com as informações sobre PELÉ

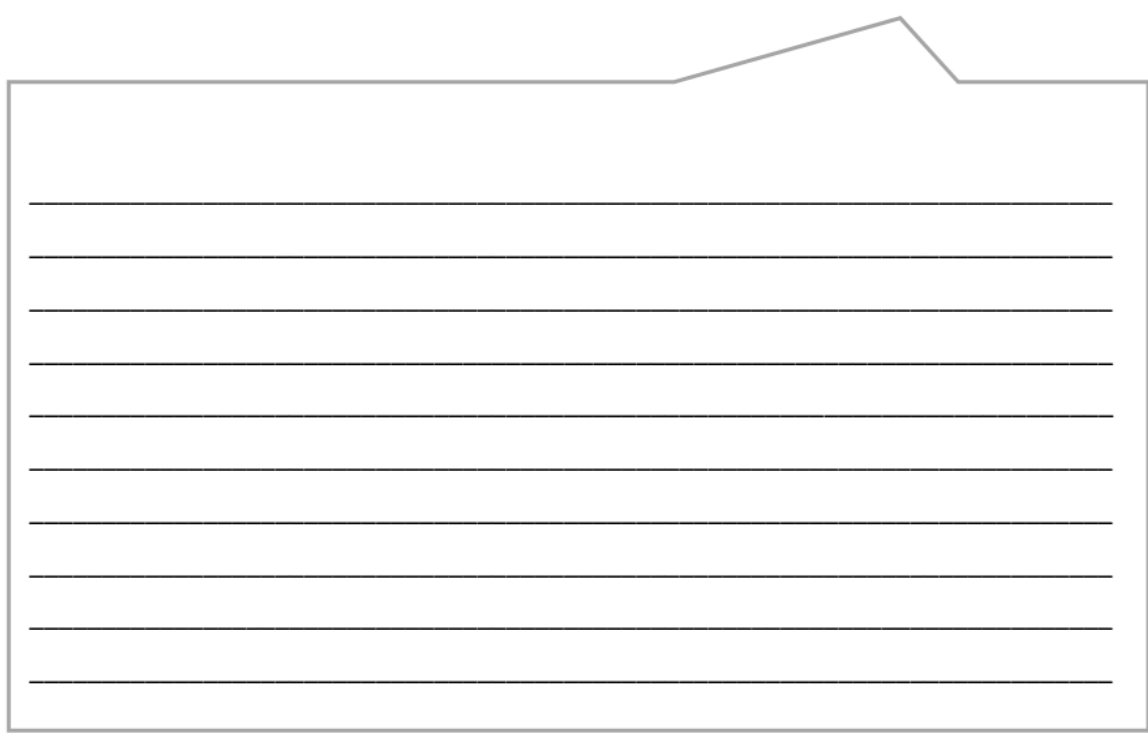


2. Escolha uma personalidade famosa de seu país e apresente sobre ela:

Nome:

Apelido:

Idade:

País:

Profissão:

Estado Civil:

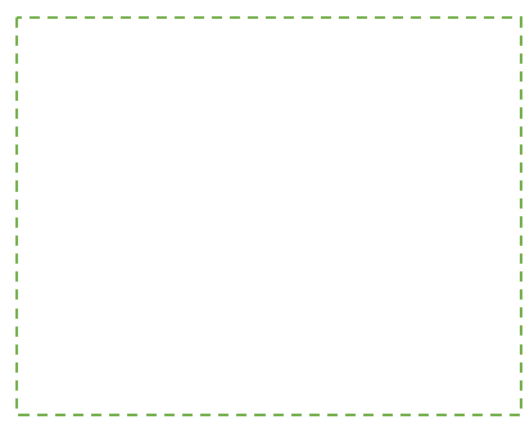

Elabore um texto com as informações dessa Personalidade e apresente aos colegas:

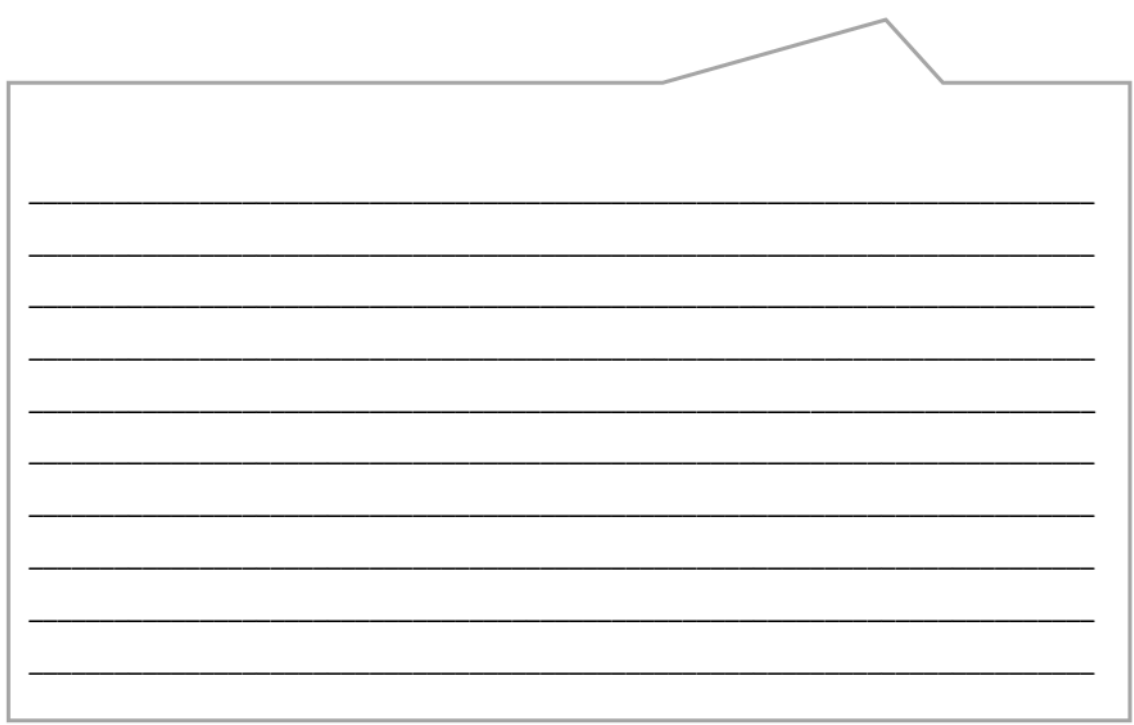




\section{APÊNDICE B - Módulo Trabalho}

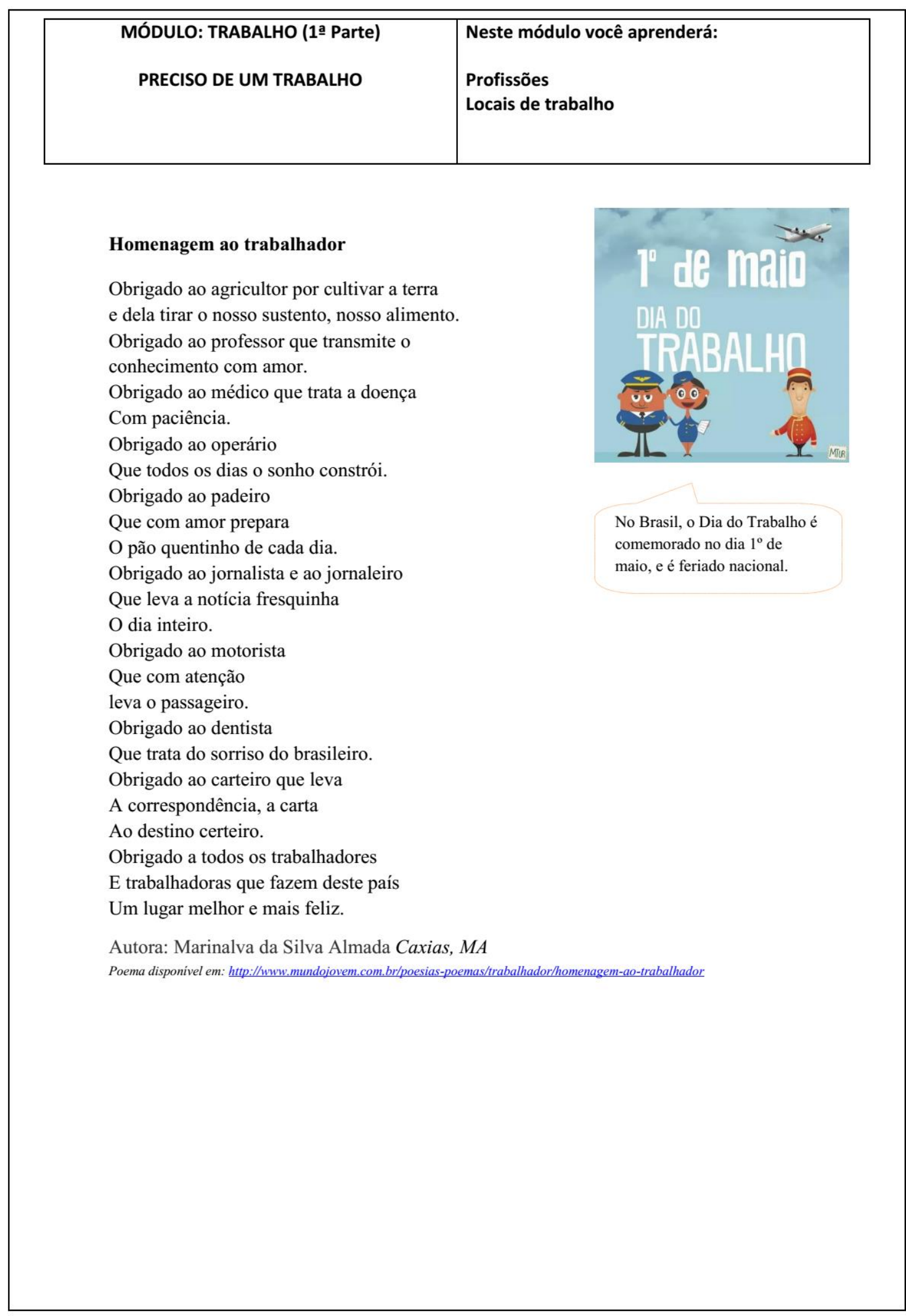




\section{TRABALHADORES}

Encontre as profissões do poema

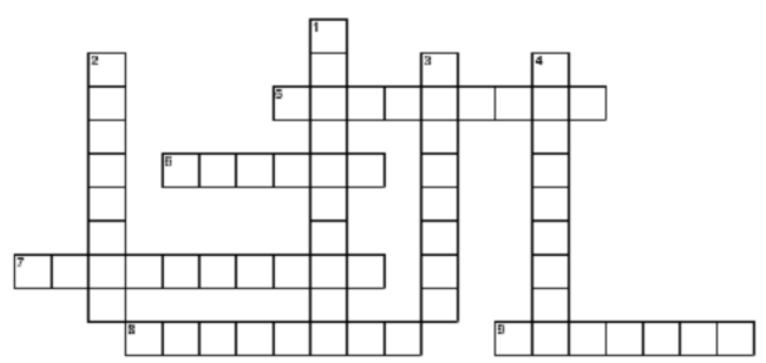

Horizontal

5. transmite o conhecimento

6. trata a doença

7. leva a noticia

8. constrói sonho

9. prepara o pão

Vertical

1. cultiva a terra

2. leva a correspondência

3. trata do sorriso

4. leva o passageiro

LOCAIS DE TRABALHO
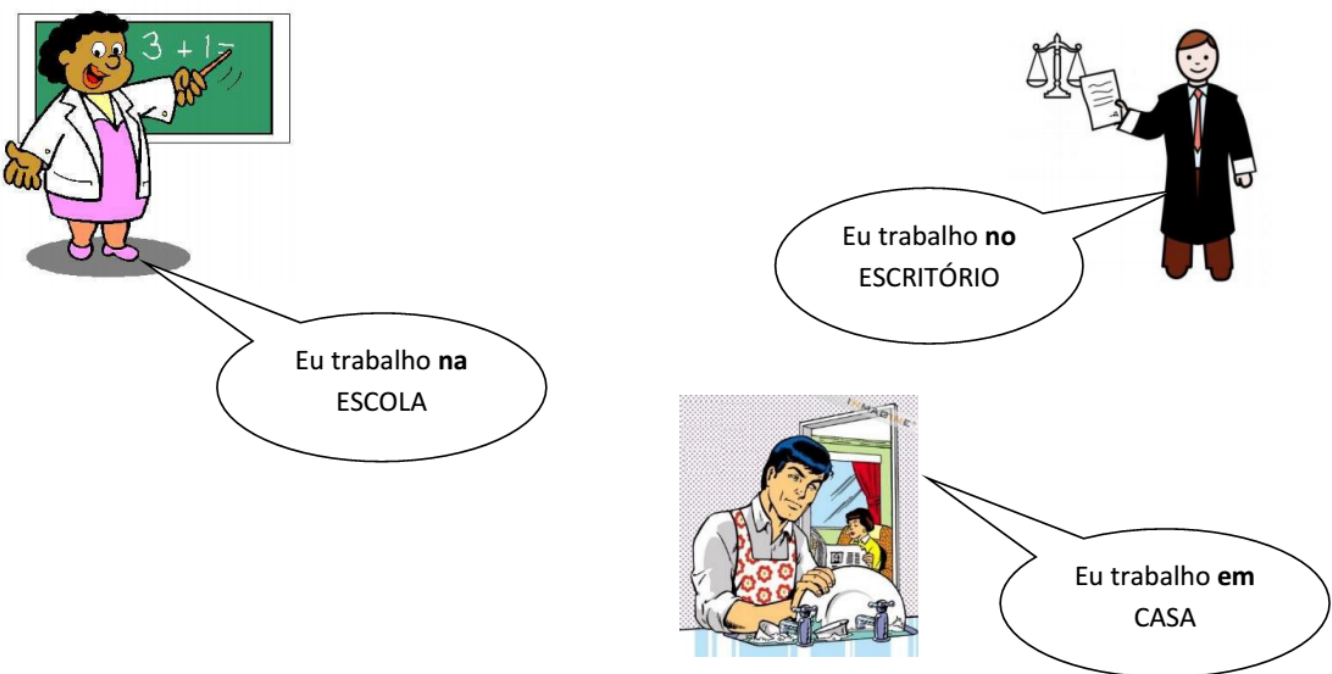
Veja:

$\diamond$ Qual é a sua profissão?

$\diamond$ Eu sou Chef de cozinha e trabalho no restaurante na Asa Sul.

○ O que você faz?

○ Eu sou garçom e trabalho no bar.

- Onde ela trabalha?

- Ela trabalha na farmácia.

Você é médico?

Não, eu sou enfermeiro e trabalho em um Hospital.

*O que o seu marido faz?

* Ele é engenheiro e trabalha em uma construção.

\section{Pratique:}

Complete com NO, NA, EM:

1. Eu trabalho Universidade de Brasília

2.Vocês trabalham em um restaurante.

3. Eles trabalham Shopping.

4. Nós trabalhamos Construção civil.

5. Elas trabalham Ministério da Saúde.

6. Eduardo e Lucia trabalham uma empresa.

\section{TEMPO PRESENTE}

\section{Verbo TRABALHAR}

Eu trabalho

Você

Ele/Ela trabalha

A gente

Nós

trabalhamos

Vocês

Eles/Elas trabalham

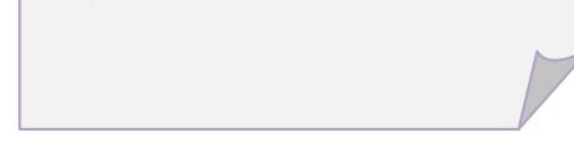

PREPOSIÇÃO

Em

$\mathrm{Em}+\mathrm{a}=\mathrm{na}$

$\mathrm{Em}+\mathrm{O}=\mathrm{no}$ 


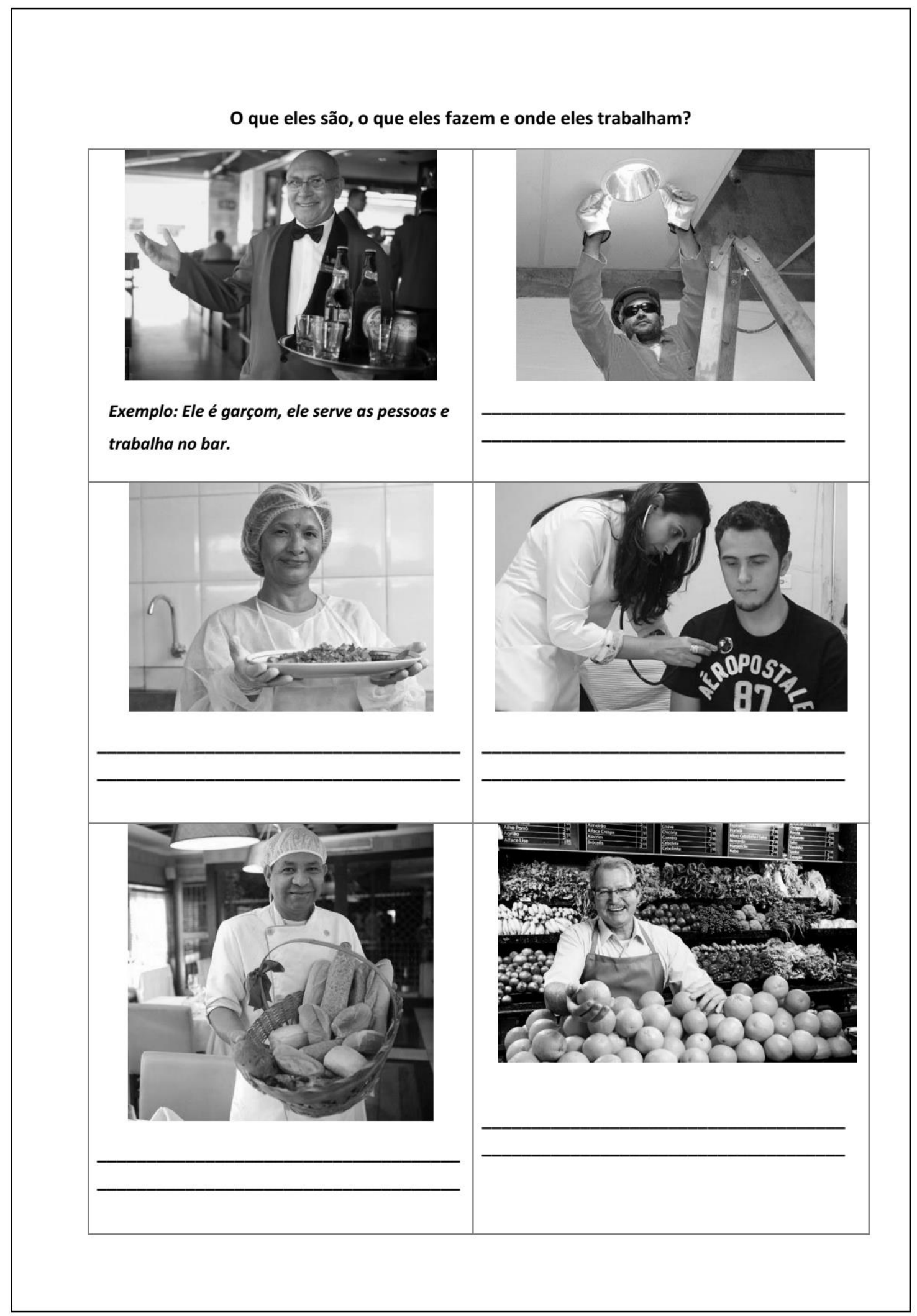




\begin{tabular}{|c|l|}
\hline MÓDULO: TRABALHO (2ª parte) & Neste módulo você aprenderá a: \\
ESTOU PROCURANDO UM EMPREGO & $\begin{array}{l}\text { Procurar um emprego; } \\
\text { Enviar um e-mail } \\
\text { Características psicológicas }\end{array}$ \\
\hline
\end{tabular}

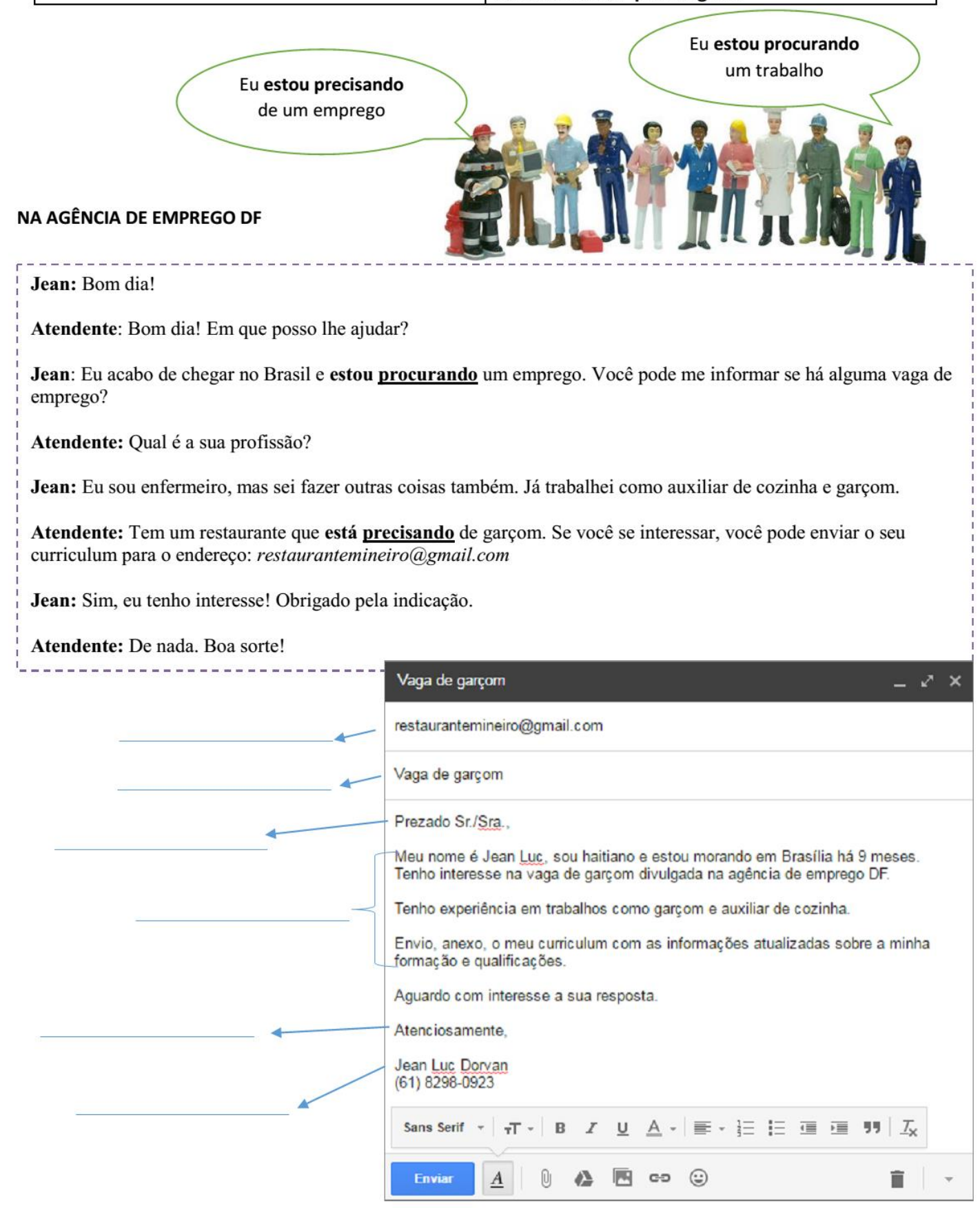




\section{O que você está procurando?}

Eu estou procurando um emprego.

Eu estou precisando de um trabalho.

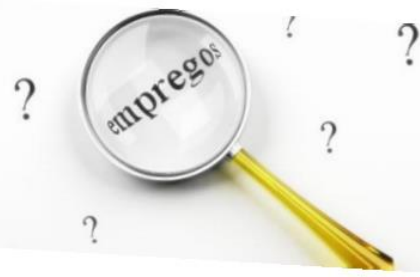

VERBO NO GERÚNDIO: serve para falar de uma ação que está em curso, está ocorrendo naquele momento presente.

Verbos $-\mathbf{A R}=$ - ando Ex.: andando (andar), falando (falar), tomando (tomar), olhando (olhar)

Verbos -ER = - endo Ex.: comendo (comer), bebendo (beber), sendo (ser), tendo (ter)

Verbos -IR = - indo Ex.: sentindo (sentir), indo (ir), dormindo (dormir), dividindo (dividir)

Exemplos: $1^{\circ} \mathrm{Com}$ verbo auxiliar: Eu estou terminando o exercício.

$2^{\circ}$ Sem verbo auxiliar: Terminando o exercício, eu vou descansar.

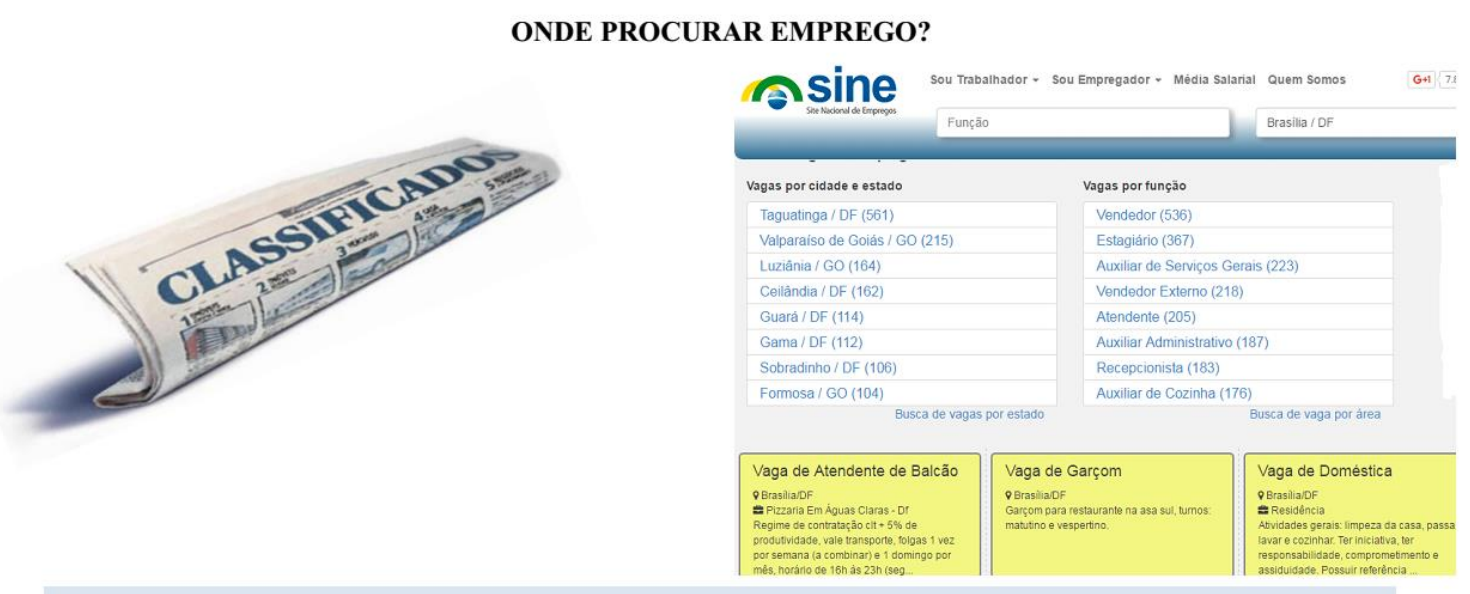

EMPREGO EM BRASÍLIA - Onde procurar?

$\checkmark$ CLASSIFICADOS DE JORNAL

$\checkmark$ LOCAIS COMO: bar, restaurante, lojas, padaria, fábrica, empresa, escola, etc.

$\checkmark$ AGÊNCIA DO TRABALHADOR (Setor Comercial Sul, Quadra 6, Lotes 10/11 - Brasília)

$\checkmark$ INTERNET - SITES:

- $\quad$ Sine: www.sine.com.br

- $\quad$ Agência virtual do trabalhador: www.agenciavirtual.df.gov.br

- $\quad$ Empregos em Brasília: www.empregosembrasilia.com.br

- $\quad$ Blog do emprego DF: www.empregodf.com.br

- $\quad$ Emprego pra ontem: www.empregopraontem.com.br 

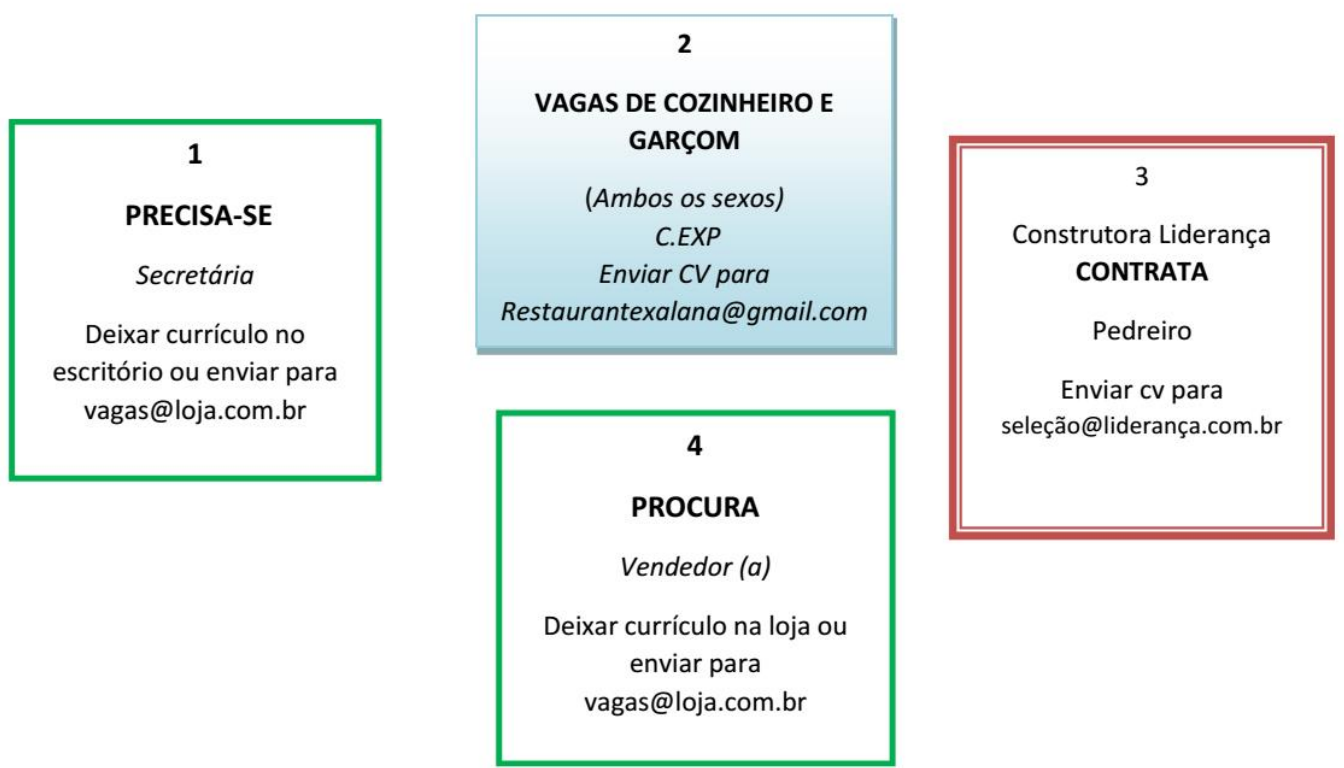

CONFORME AS CARACTERISTICAS EXPRESSAS NOS BALÕES, ENCONTRE A MELHOR VAGA DE EMPREGO:

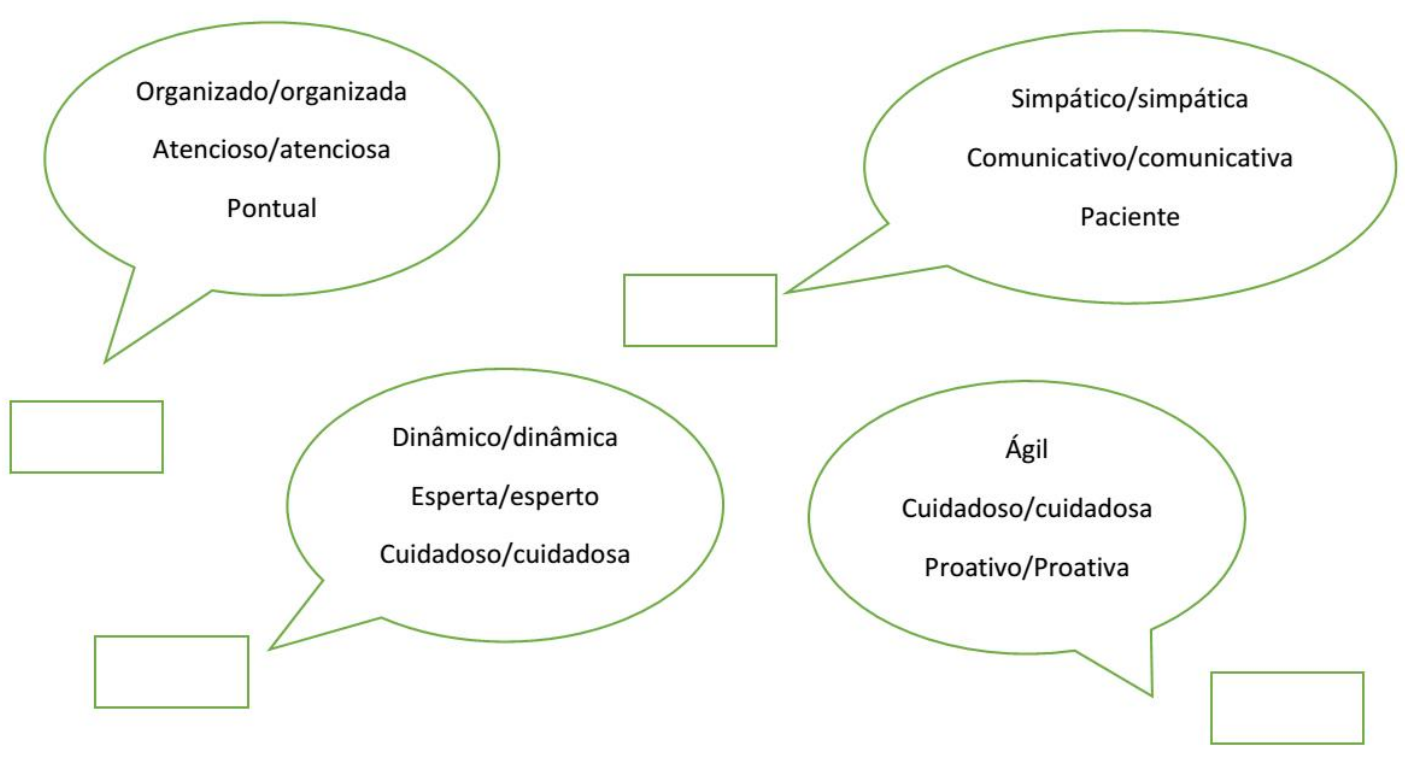




\section{EXERCÍCIOS}

\section{Complete com os verbos no Gerúndio:}

a) Ele (trabalhar) em um restaurante italiano à noite.

b) Ela (procurar) uma casa para alugar.

c) Nós (precisar) de uma informação.

d) Elas não (querer) ficar em casa.

e) Você (estudar) português no NEPPE?

f) A gente (conhecer) o mercado da Asa Norte.

g) Eu e elas (morar) perto da rodoviária do Plano Piloto.

h) As crianças (dormir) cedo.

i) Nós não (assistir) o jogo.

\section{Crie pequenos textos com os dados dos personagens abaixo:}

Exemplo: Carlos Perez, cubano, 42 anos, médico, posto de saúde, atencioso, paciente.

Carlos Perez é cubando, tem 42 anos e trabalha no Posto de Saúde. Ele é atencioso e paciente.

Maria Clara Santos, brasileira, dentista, centro de odontologia, cuidadosa, organizada.

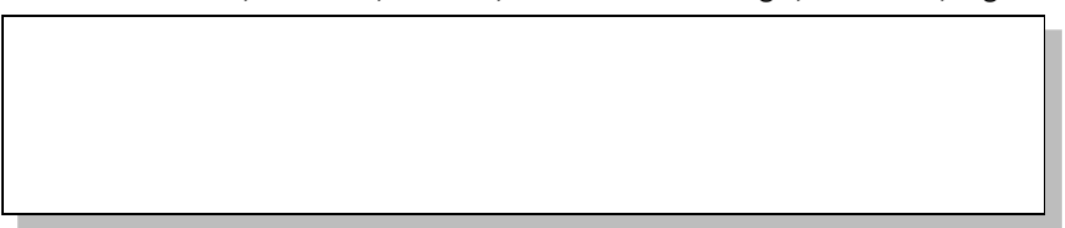

José Lima, colombiano, casado, engenheiro, esperto, pontual.

\section{ESCREVA SOBRE VOCÊ:}


3. Complete com O, A, OS, AS:

\begin{tabular}{llll} 
restaurante & jornal & consultórios & construções \\
\cline { 2 - 3 } estrada & salão de beleza & açougue & parada de ônibus \\
lojas & mercado & táxi & hospitais \\
escola & problema & casas & shopping
\end{tabular}

4. Ligue as profissões com suas respectivas funções:
1. Dentista
( ) entrega correspondências
2. padeiro
( 1 ) trata dos dentes
3. carteiro
( ) leva as pessoas nos lugares
4. empresária
( ) faz pães
5. taxista
( ) administra uma empresa
6. chef de cozinha
( ) limpa
7. bombeiro
( ) cozinha
8. feirante
( ) ensina
9. diarista
( ) socorre as pessoas
10. professora
( ) vende verduras e frutas

5. Do que você precisa?

\begin{tabular}{lll}
\hline Informação & $\begin{array}{l}\text { trabalho falar português } \\
\text { descansar }\end{array}$ \\
\hline
\end{tabular}

Exemplo: Ele está perdido na rua.

Ele precisa de uma informação

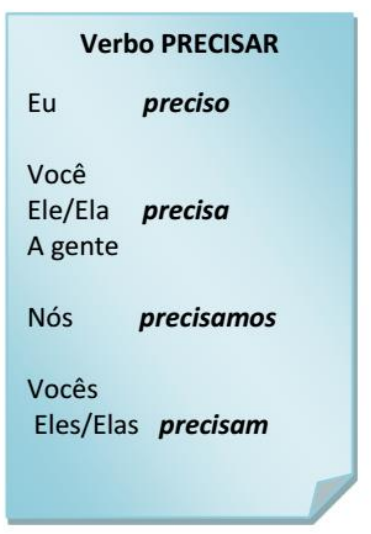

1. Eu estou desempregado.

2. Nós somos estrangeiros no Brasil.

3. A gente está cansado. 


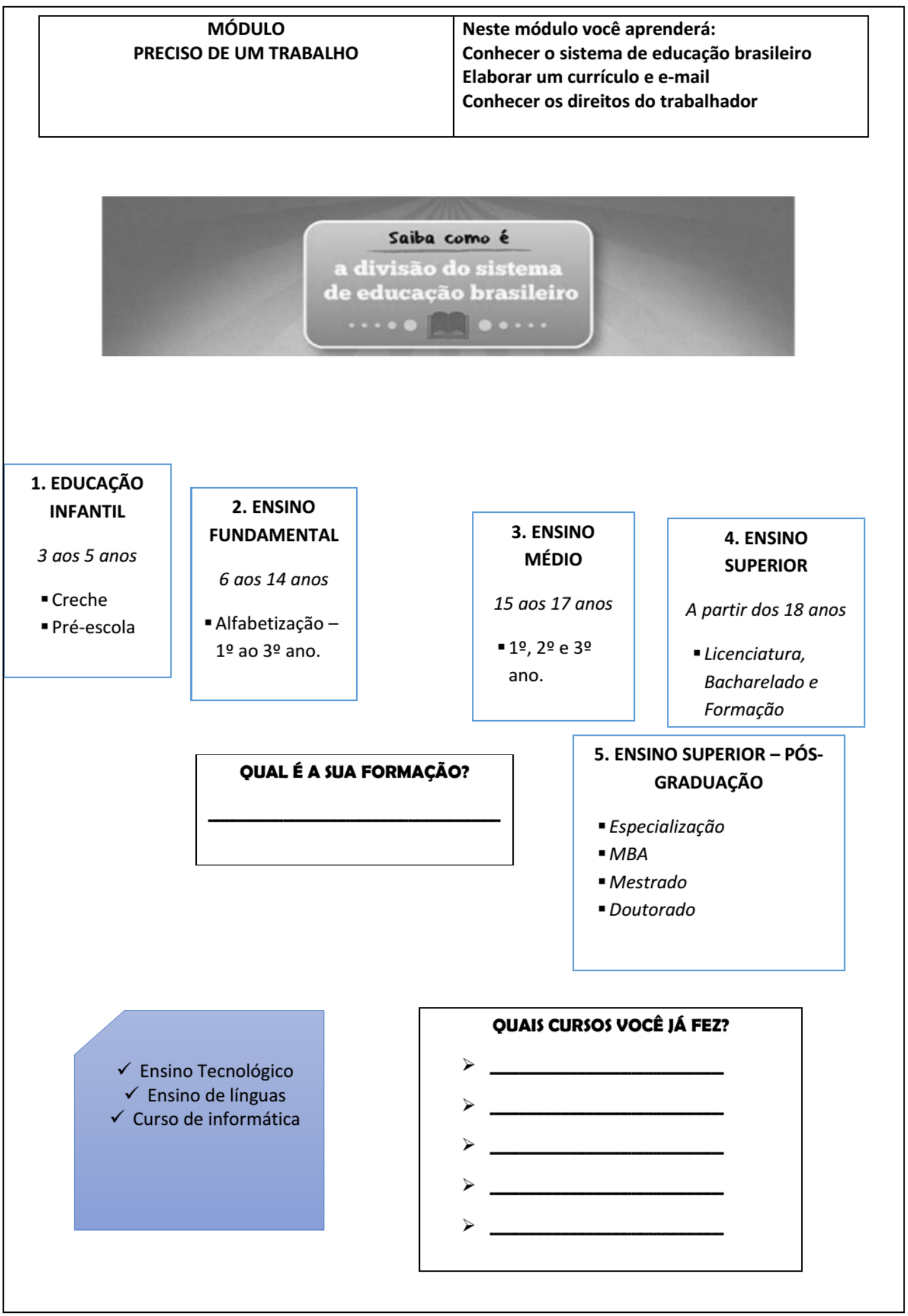




\section{Onde estudar em Brasília?}

(Ensino superior e tecnológico público)

- Universidade de Brasília - UnB - www.unb.br

- Instituto Federal de Brasília - IFB - www.ifb.edu.br

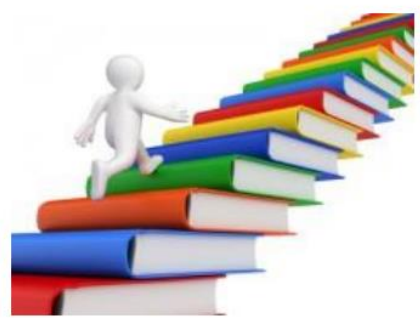

(Brasília, Ceilândia, Estrutural, Gama, Planaltina, Riacho Fundo, Samambaia, São

Sebastião, Taguatinga, Taguatinga Centro)

- SENAI (Serviço Nacional de Aprendizagem Industrial) www.portaldaindustria.com.br/senai/

(Brasília, Taguatinga e Gama)

\section{Cursos de qualificação profissional disponíveis:}

\begin{tabular}{lll} 
Municipio & \multicolumn{1}{c}{ Instituiçäo/Órgão } & \\
BRASILIA & CGTB/DF & VENDEDOR PRACISTA \\
BRASILIA & CGTB/DF & PROMOTOR DE VENDAS \\
BRASILIA & IMDC - MG & EMPREGADO DOMESTICO NOS SERVIÇOS GERAIS \\
BRASILIA & DF - SETRAB & ARTESANATO EM ARGILA \\
BRASILIA & DF - SETRAB & CONFECCAO DE PECAS(DECORATIVO E UTILITARIO) \\
BRASILIA & DF - SETRAB & PINTURA EM TELA E TECIDO \\
BRASILIA & FENAMOTO & MOTOFRETISTA \\
BRASILIA & ICEP & CAMAREIRO \\
BRASILIA & ICEP & PORTEIRO/MENSAGEIRO \\
BRASILIA & ICEP & GARÇOM \\
BRASILIA & ICEP & BARMAN \\
BRASILIA & DF - SETRAE & JARDINEIRO \\
BRASILIA & DF - SETRAB & EMPREGADODOMESTICO DIARISTA \\
BRASILIA & DF - SETRAB & MOTORISTA DE ONIBUS \\
BRASILIA & DF - SETRAB & COZINHEIRO \\
BRASILIA & DF - SETRAB & BABA \\
BRASILIA & DF - SETRAB & BORDADO A MAO \\
BRASILIA & DF - SETRAB & CONFECCAO DE PECAS(CHINELOS E BIJUTERIAS) \\
BRASILIA & IMDC - MG & CUIDADOR DE IDOSOS \\
BRASILIA & DF - SETRAB & COBRADOR DE TRANSPORTE COLETIVO \\
BRASILIA & DF - SETRAB & EMISSOR DE PASSAGENS \\
BRASILIA & DF - SETRAB & LIMPADOR DE PISCINAS \\
BRASILIA & DF - SETRAB & CUIDADOR DE IDOSOS \\
BRASILIA & DF - SETRAB & MANUTENÇAO DE EDIFICAÇOES \\
BRASILIA & DF - SETRAB & COMERCIANTE VAREJISTA \\
BRASILIA & DF - SETRAB & ORGANIZADOR DE EVENTOS \\
BRASILIA & DF - SETRAB & AGENTE DE VIAGEM \\
BRASILIA & IMDC - MG & COZINHADOR \\
BRASILIA & DF - SETRAB & GUIA DE TURISMO \\
& &
\end{tabular}

Caso se interesse por algum curso, acesse o site:

http://gc.maisemprego.mte.gov.br/gcweb/pages/consultaCurso/consultarCurso.xhtml 


\section{ANTÔNIO NASCIMENTO}

\section{DADOS PESSOAIS}

Data de nascimento: 01 de novembro de 1980 Nacionalidade: Brasileiro

Telefone: (61) 82040937

E-mail: nicolauferben@gmail.com

\section{FORMAÇÃO OU ESCOLARIDADE}

- Ensino Médio completo

- Curso de Gastronomia incompleto

\section{IDIOMAS}

Francês (língua materna)

Espanhol intermediário

Inglês básico

Português*

*Em aprendizagem no NEPPE/UnB.

\section{EXPERIÊNCIAS DE TRABALHO}

Empregador: Restaurante Comida da Vovó Função/atividade: Auxiliar de cozinha

Período de trabalho: 2008- 2015

Local: São Paulo

Empregador: Casa dos parafusos

Função/atividade: Vendedor

Período de trabalho: 2005- 2008

Local: São Paulo

\section{CONHECIMENTO DE INFORMÁTICA}

(X) Word (X)Excel (X) Internet ( ) Apenas iniciação Outros aplicativos: demais ferramentas Microsoft Office

\section{HABILIDADES PESSOAIS}

Flexibilidade, capacidade de lideranças, pontualidade e confiabilidade.

Obs: Avalio exercer cargos variados e com total disponibilidade de tempo.

Referências no Brasil: Jualiana Souza- 32435678 e NEPPE- 3107-5833

Local e Data:

Assinatura:

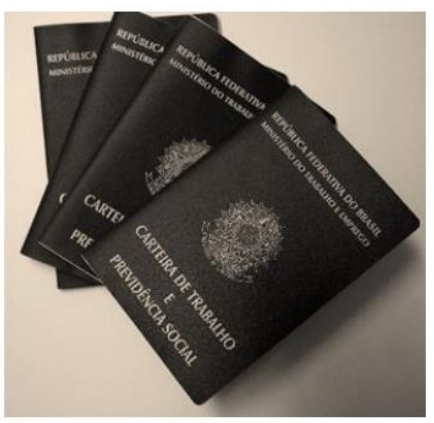

\section{DADOS PESSOAIS}

Data de nascimento:

Nacionalidade:

Telefone:

E-mail:

\section{FORMAÇÃO OU ESCOLARIDADE}

\section{IDIOMAS}

\section{EXPERIÊNCIAS DE TRABALHO}

Empregador:

Função/atividade:

Período de trabalho:

Local:

\section{CONHECIMENTO DE INFORMÁTICA}

( ) Word ( )Excel ( ) Internet ( ) Apenas iniciação Outros aplicativos: demais ferramentas Microsoft Office

\section{HABILIDADES PESSOAIS}

Obs:

Referências no Brasil: Local e Data:

Assinatura: 

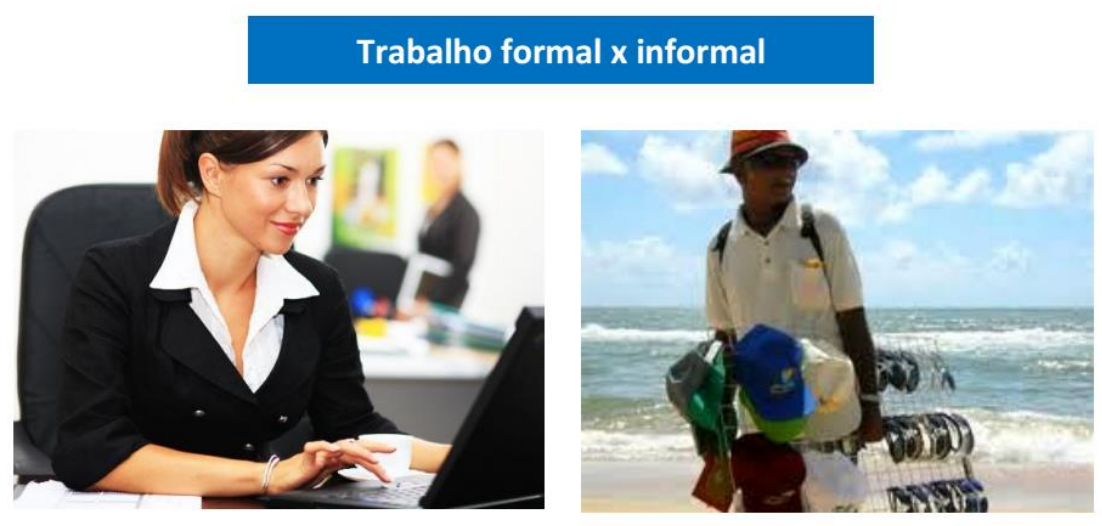

Trabalho formal

Trabalho Informal:

$\checkmark$ Carteira profissional assinada

$\checkmark$ Salário

$\checkmark$ Benefícios

$\checkmark$ Aposentadoria

$\checkmark$ Décimo Terceiro salário

$\checkmark$ Hora extra remunerada

$\checkmark$ Licença maternidade e paternidade

$\checkmark$ Férias

$\checkmark$ Seguro-desemprego

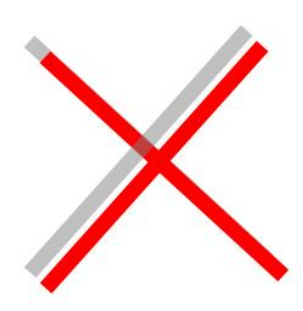

\begin{tabular}{|c|c|}
\hline CARTEIRA DE TRABALHO & Documento obrigatório que registra a vida profissional dos brasileiros. \\
\hline SALÁRIO & O salário mínimo no Brasil é de $\mathrm{R} \$ 880,00$ \\
\hline BENEFÍCIOS & $\begin{array}{l}\text { A combinar com a empresa, por exemplo: } \\
\text { - Vale transporte, vale alimentação, convênio médico e odontológico. }\end{array}$ \\
\hline APOSENTADORIA & $\begin{array}{l}\text { Urbano: Homem: } 65 \text { anos / Mulher: } 60 \text { anos } \\
\text { Rural: Homem: } 60 \text { anos / Mulher: } 55 \text { anos }\end{array}$ \\
\hline 13 SALÁRIO & Salário extra ao trabalhador no final de cada ano. \\
\hline HORA EXTRA & $\begin{array}{l}\text { Duração normal do trabalho: } 8 \text { horas diária / } 44 \text { horas semanais. } \\
\text { Maior que essa duração, deverá receber horas extras: } 50 \% \text { superior à da } \\
\text { hora normal. }\end{array}$ \\
\hline FÉRIAS & $\begin{array}{l}\text { Férias é o período de descanso anual. Após } 12 \text { meses de trabalho tem } \\
\text { direito a férias. }\end{array}$ \\
\hline SEGURO DESEMPREGO & $\begin{array}{l}\text { O trabalhador com carteira assinada que trabalhou, no mínimo, } 12 \text { meses e } \\
\text { perdeu o emprego sem justa causa, terá direito ao seguro desemprego. }\end{array}$ \\
\hline
\end{tabular}




\section{É importante saber:}
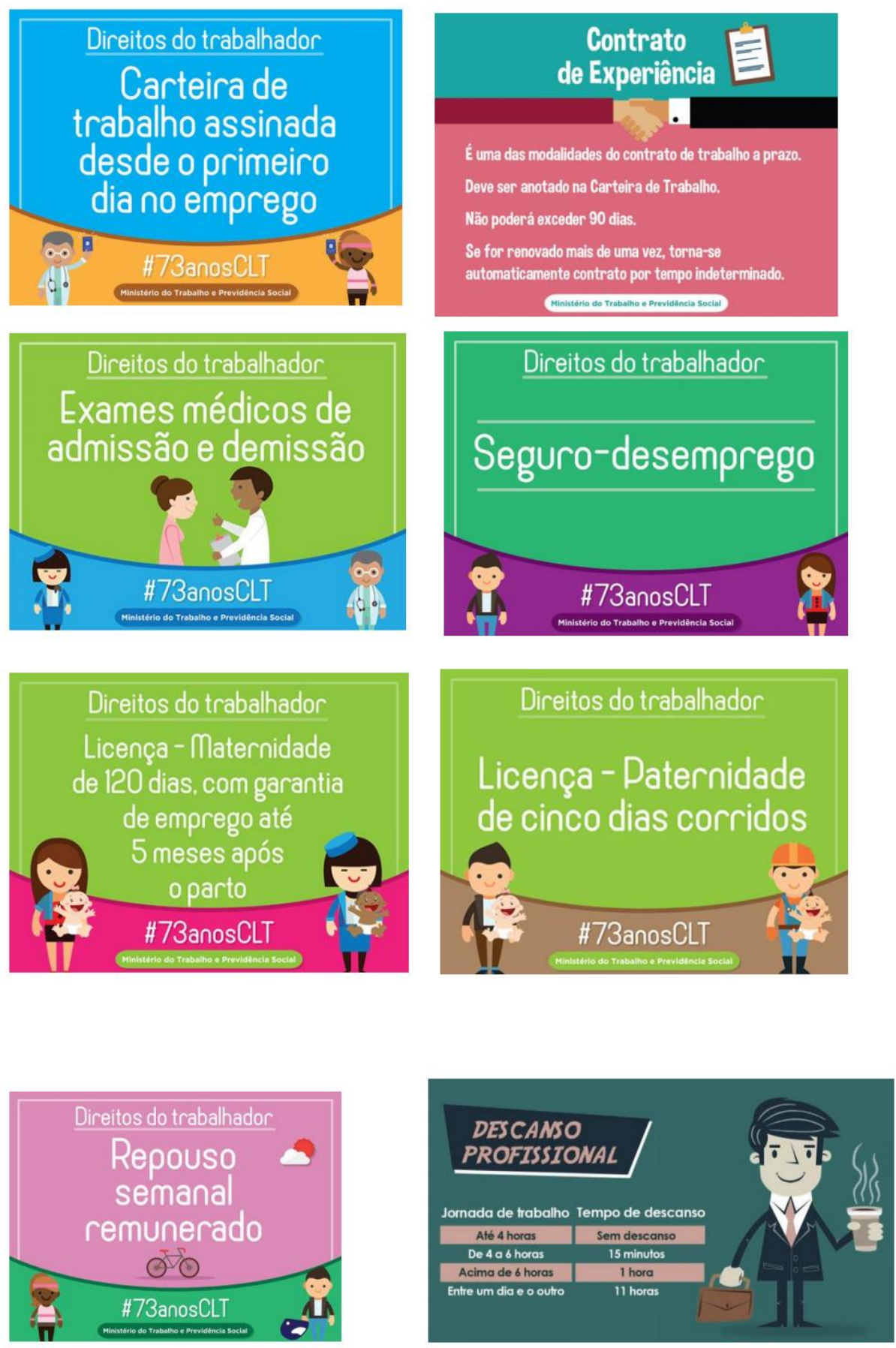
FGTS e Seguro-Desemprego são benefícios diferentes. $O$ Seguro-Desemprego promove a assistência financeira para o desempregado demitido sem justa causa. Já o FGTS é o Fundo de Garantia do Tempo de Serviço e, com ele, o trabalhador tem a oportunidade de formar um patrimônio que pode ser sacado em momentos especiais, como a compra da casa própria ou da aposentadoria e em situações de dificuldades, como a demissão sem justa causa, doenças graves, desastres naturais, entre outros. (Fonte: Ministério do Trabalho e Emprego)

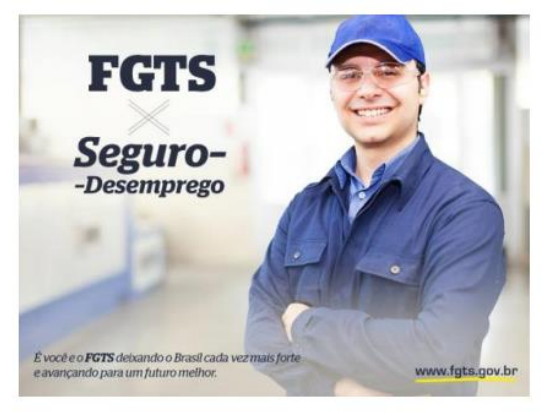

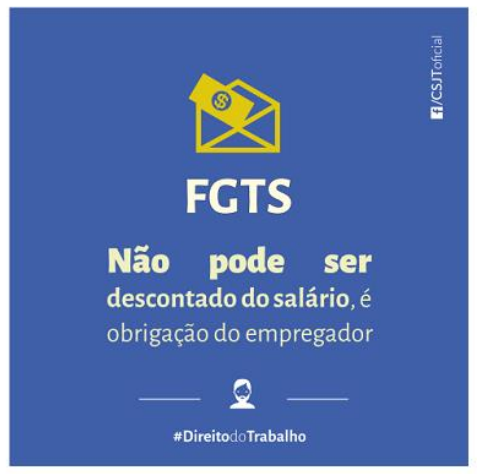
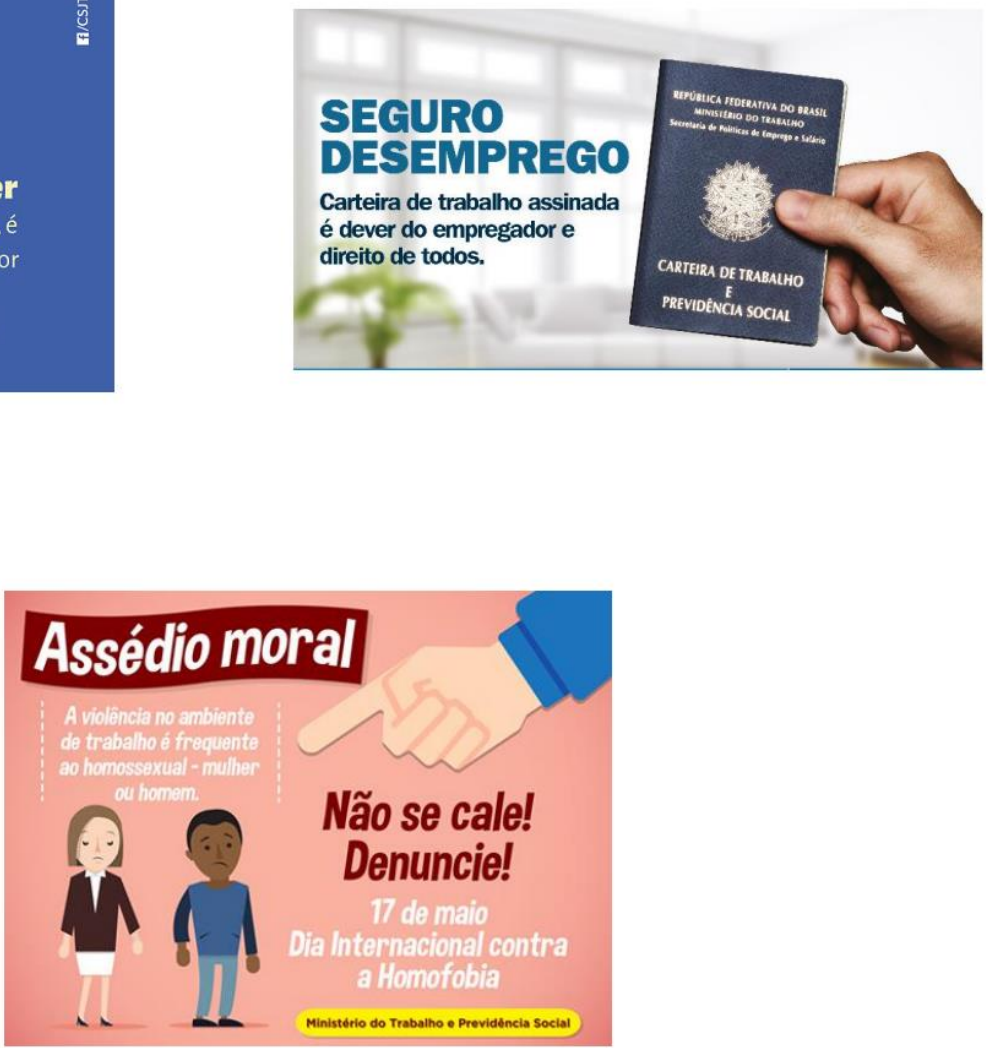


\section{EXERCÍCIO 1}

Veja as oportunidades de trabalho. Complete os quadros com as informações corretas:

\section{Anúncio}

\begin{tabular}{|c|c|c|}
\hline :Z: & \multirow[t]{2}{*}{$\begin{array}{l}\text { Atendente de loja } \\
\text { Confidencial / Brasilia / DF - 1 vaga } \\
\text { Publicada em 17/09/2014 }\end{array}$} & \\
\hline Dados da vaga & & \multirow{2}{*}{$\begin{array}{l}\text { Salário: } \\
\text { A combinar } \\
\text { =ill Veja média salarial }\end{array}$} \\
\hline Descriçäo: & $\begin{array}{l}\text { Irá dar suporte ao garçom no atendimento ao cliente. Conhecimento } \\
\text { em informática. }\end{array}$ & \\
\hline Qualificação: & Proativo e dinàmico. Desejável experiència na função de atendente. & \multirow{3}{*}{$\begin{array}{l}\text { Forma de contratação: } \\
\text { A Combinar } \\
\text { Beneficios: } \\
\text { A Combinar }\end{array}$} \\
\hline Formação: & Ensino Médio completo. & \\
\hline Local de trabalho: & Brasilia / DF - 1 vaga & \\
\hline
\end{tabular}

\section{Cargo:}

Formação:

Salário:

Benefícios:

Local de trabalho: 


\section{Anúncio}

REPOSITOR - SHOPPING CENTER CONJ. NACIONAL BRASÍLIA

RI HAPPY Brinquedos - Brasilia, DF

Reposição de mercadorias.

Manhã ou Tarde, necessário disponibilidade para trabalhar aos fins de semana e feriados

Salario + vale transporte

Tipo de contrato: Temporário

Indeed - há 7 dias - salvar vaga - bloquear

") Candidate-se Agora

Por favor, leia as instruções sobre como se inscrever a vaga antes de se candidatar.

Candidate-se

\begin{tabular}{|l|}
\hline Cargo: \\
\hline Formação: \\
\hline Salário: \\
\hline Benefícios: \\
\hline Local de trabalho: \\
\hline
\end{tabular}




\section{Anúncio}

\section{Recepcionista}

Confidencial | Taguatinga / DF - 1 vaga Publicada em 21/08/2014

\section{Dados da vaga \\ Descrição: Irá atender, transferir ligações, atender moto -boys, anotar recados e demais atividades na função. \\ Qualificação: Desejável conhecimento intermediário do pacote office, bons conhecimentos em informática, vivência na área comercial e com atendimentos. \\ Formação: Ensino médio incompleto. \\ Local de trabalho: Taguatinga / DF - 1 vaga}

Salário:

A combinar

aill Veja média salarial

Forma de contratação: A Combinar

Beneficios:

Vale Refeição

Assistência Médica

Assistência Odontológica

Cargo:

Formação:

Salário:

Benefícios:

Local de trabalho: 
EXERCÍCIO 2

\section{A cigarra e a formiga}

Num dia soalheiro de Verão, a Cigarra cantava feliz. Enquanto isso, uma Formiga passou por perto. Vinha afadigada, carregando penosamente um grão de milho que arrastava para o formigueiro.

- Por que não ficas aqui a conversar um pouco comigo, em vez de te afadigares tanto? - perguntou-lhe a Cigarra.

- Preciso de arrecadar comida para o Inverno - respondeu-lhe a Formiga. Aconselho-te a fazeres o mesmo.

- Por que me hei de preocupar com o Inverno? Comida não nos falta... respondeu a Cigarra, olhando em redor.

A Formiga não respondeu, continuou o seu trabalho e foi-se embora.

Quando o Inverno chegou, a Cigarra não tinha nada para comer. No entanto, viu que as Formigas tinham muita comida porque a tinham guardado no Verão. Distribuiam-na diariamente entre si e não tinham fome como ela. A Cigarra compreendeu que tinha feito mal...

Moral da história:

Não penses só em divertir-te. Trabalha e pensa no futuro.

Fabulas de La fontaine

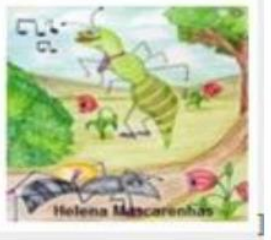

\section{INTERPRETANDO A FÁBULA:}

\section{Escreva algumas características dos personagens abaixo:}

Cigarra:

Formiga:

2. Qual é a moral da fábula?

\section{O que você faria se estivesse no lugar da cigarra?}




\section{2a TAREFA AVALIATIVA-Módulo trabalho}

\section{(Entregar para a professora)}

\section{Ligue o sentido de cada palavra:}
1. Salário
( ) Dinheiro que recebe ao final do ano.
2. Benefícios
( ) Descanso
3. Décimo terceiro
( ) Documento de trabalho formal .
4. Carteira de trabalho
( ) Dinheiro que recebe ao final do mês.
5. Férias
( ) Vale transporte, vale alimentação.
6. Hora extra
( ) Trabalha mais que 8 horas por dia.

\section{Preencha as informações:}

\section{Vaga: Encarregado de estoque}

\section{OPORTUNIDADE DE TRABALHO}

Local: Brasília - DF

Salário: $\mathrm{R} \$ 1.700,00$

Benefícios: Vale transporte e vale alimentação

Horário de trabalho: Segunda-feira a sexta-feira em horário comercial ( $8 \mathrm{~h} 00$ às $18 \mathrm{~h} 00)$ e sábado meio período ( $8 \mathrm{~h} 00$ às $12 \mathrm{~h} 00)$.

Formação: Ensino Médio

Experiência: Não precisa de experiência

Interessados enviar currículo para pedro.castello@kellyservices.com e colocar no título do e-mail ENCARREGADO

\section{Cargo:}

\section{Formação:}

Salário:

Benefícios:

Local de trabalho:

\section{Horário de trabalho:}

Experiência:

\section{Escreva um e-mail apresentando o seu interesse pela vaga do anúncio do exercício 2}


Destinatánios

Assunto

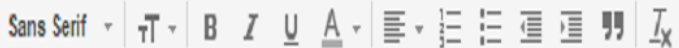

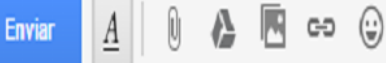




\title{
APÊNDICE C - Termos de consentimentos
}

\author{
Programa de Pós-Graduação em Linguística Aplicada \\ Universidade de Brasília
}

Termo de consentimento

Eu, abaixo assinado e identificado concordo em participar da pesquisa de mestrado do Programa de Pós-Graduação em Linguística Aplicada (PGLA) da Universidade de Brasília, desenvolvida pela pesquisadora Lígia Soares Sene durante o período de 21 de março a 05 de julho de 2016.

Eu entendo e estou de acordo com:

- A captação e publicação da minha imagem e demais dados biográficos revelados durante as atividades Interculturais- Chá \&Prosa e Despertar Profissional - promovidas durante o curso Português para estrangeiros Módulo Acolhimento, ofertado pelo Núcleo de Ensino e Pesquisa em Português para Estrangeiros (NEPPE);

- Autorizo também a utilização dos documentos, tais como curriculum, portfólio profissional, questionários, atividades escritas elaborados durante o curso para fins de análise e publicação;

- Declaro que a presente autorização é feita a TíTULO GRATUITO

A presente autorização é firmada, sem qualquer restrição de prazo, a título gratuito.

Brasília, 28 de Junho de 2016

\begin{tabular}{|l|}
\hline NOME DO ALUNO \\
\hline CPF: \\
\hline ASSINATURA: \\
\hline
\end{tabular}


Módulo Acolhimento - Português para Refugiados e Imigrantes Termo de consentimento

\section{Brasília, 25 de abril de 2016}

Eu, abaixo assinado e identificado, autorizo a captação e publicação em website e em mídia veiculante, assim como para utilização em pesquisa do Programa de Pós-Graduação de Linguística Aplicada da Universidade de Brasília e divulgação do Projeto Demonstre o Amor Amando, a utilização de minha imagem e demais dados biográficos revelados na Atividade Intercultural CHÁ \& PROSA.

A presente autorização é firmada, sem qualquer restrição de prazo, a título gratuito.

\begin{tabular}{|l|l|l|l|}
\hline & NOME & PAIS & E-MAIL \\
\hline 1 & & & \\
\hline 2 & & & \\
\hline 3 & & & \\
\hline 4 & & & \\
\hline 5 & & & \\
\hline 6 & & & \\
\hline 7 & & & \\
\hline 8 & & & \\
\hline 10 & & & \\
\hline
\end{tabular}

Módulo Acolhimento - Português para Refugiados e Imigrantes Termo de consentimento

Brasilia, 31 de maio de 2016

Eu, abaixo assinado e identificado, autorizo a captação e publicação minha imagem e demais dados biográficos revelados na Atividade Intercultural Despertar Profissional em website e em mídia veiculante, assim como para utilização em pesquisa do Programa de Pós-Graduação de Linguística Aplicada da Despertar Profissional em website e em mídia veiculante, assim como para utiliza
Universidade de Brasilia e divulgação do Projeto Demonstre o Amor Amando.

Autorizo também a apresentação e a publicação do portfólio profissional elaborado nesta mesma atividade para empresas, instituições e interessados em estabelecer contatos profissionais.

A presente autorização é firmada, sem qualquer restrição de prazo, a título gratuito.

\begin{tabular}{|l|l|l|l|}
\hline & NOME & PAís & RNE/CPF \\
\hline 1 & & & \\
\hline 2 & & & \\
\hline 3 & & & \\
\hline 4 & & & \\
\hline 5 & & & \\
\hline 6 & & & \\
\hline 7 & & & \\
\hline 8 & & & \\
\hline
\end{tabular}




\section{APÊNDICE D - Questionário- Perfil da turma do Acolher 1}

\section{Ficha Pessoal \\ Données Personnelles \\ Personal information form}

1. Nome/ Non/ Name:

2. Sexo: ( ) masculino / homme/male ( ) feminino / femme / female

3. Nacionalidade/ Nacionalité/ Nationality:

4. Data de nascimento/ Date de naissance/ Birth date:

5. Estado civil/ État civil / Marital Status:

( ) solteiro/ célibataire/single ( ) casado/marié(e)/married ( ) viúvo/veuf / widowed

6. Endereço/ adresse/ address:

7. Telefone/ téléphone/ phone number: ( )

8. E-mail:

9. Com quem você mora? / Vouz habitéz avec qui? / Who do you live with?

( ) sozinho / seul / alone ( ) amigos / collègues / friends ( ) família / famille / Family

10. Você está trabalhando no Brasil? / Avez-vouz un emploi au Brésil? / Do you have a job in Brazil?
( ) $\operatorname{sim} /$ oui / yes
( ) não / non / no

11. Qual é a sua disponibilidade durante a semana? / Quelle est votre disponibilité pendant la semaine? / What is your disponibility during the week?

( ) manhã / matin / morning ( ) tarde / après-midi / afternoon ( ) noite / soir / night 


\section{QUESTIONÁRIO}

Este questionário tem por objetivo coletar dados para o Núcleo de Ensino e Pesquisa em Português para Estrangeiros (NEPPE) e para pesquisa do Programa de Pós-Graduação em Linguística Aplicada (PGLA) da Universidade de Brasilia.

1. Qual é a sua língua materna?
( ) Inglês
( ) Francês
( ) Árabe
( )Farsi
( ) Urdu
( ) Criolo francês
( ) Pastho
( ) Espanhol

Outra:

2. Qual é o seu nível de escolaridade?

( ) Ensino Fundamental

( ) Ensino Médio

( ) Ensino Superior

( ) Pós-graduação

3. Qual era a sua profissão no seu país?

4. Que outras línguas você fala?
( ) Inglês
( ) Francês
( ) Árabe
( )Farsi
( ) Urdu
( ) Criolo francês
( ) Pastho
( ) Espanhol

Outra:

5) Você estudou formalmente uma língua (na escola ou curso de línguas)?

( ) $\operatorname{sim}$

( ) não

Se sim, por quanto tempo?

( ) 1 a 6 meses

( ) 7 meses a 1 ano

( ) mais que um ano

7) Há quanto tempo você está no Brasil?

( ) Recém-chegado

( ) 1 a 6 meses

( ) 7 meses a 1 ano

( ) Mais de 1 ano

8) Por quais razões você mudou para o Brasil?
( ) Refúgio
( ) para ter uma melhor vida
( ) razões profissionais
( ) viver com a minha família
( ) conhecer um novo país e uma nova cultura Outros:


9) Você já estudou português?

( ) Não

( ) $\operatorname{Sim}$

Onde?

9) Em Brasília há outros cursos de língua portuguesa. Marque os motivos que o levaram a escolher o curso de língua portuguesa do NEPPE:

( ) é mais perto de onde moro

( ) tem certificado de conclusão

( ) é na Universidade

( ) tem boa estrutura

( ) tem material em português

( ) tem mais horas de aula

Outros:

10) Qual é a seu objetivo após fazer este curso? 


\section{APENDICE E - Questionários Atividades Interculturais}

\section{Neppe}

\section{QUESTIONÁRIO- PORTUGUÊS}

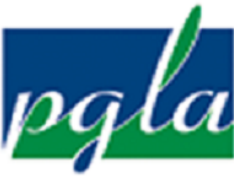

Este questionário tem por objetivo coletar dados para o Núcleo de Ensino e Pesquisa em Português para Estrangeiros (NEPPE) e para pesquisa do Programa de Pós-Graduação em Linguística Aplicada (PGLA) da Universidade de Brasília.

1. Marque o você achou da atividade $C H A ́ A$ \& PROSA realizada hoje?
( ) muito ruim
( ) ruim
( ) razoável
( ) boa
( ) muito boa

2. Qual o tema você mais gostou de ouvir?
( ) sobre o seu país
( ) sobre habilidades, trabalho e estudos
( ) lazer e diversão
( ) sobre o Brasil

3. Escreva o que você achou e aprendeu com a atividade de hoje: 


\section{APÊNDICE F - Notas de Campo}

\section{QUESTIONÁRIO- PORTUGUÊS}

Este questionário tem por objetivo coletar dados para o Núcleo de Ensino e Pesquisa em Português para Estrangeiros (NEPPE) e para pesquisa do Programa de Pós-Graduação em Linguística Aplicada (PGLA) da Universidade de Brasília.

1. Marque o você achou da atividade Despertar profissional realizada hoje?

( ) muito ruim

( ) ruim

( ) razoável

( ) boa

( ) muito boa

\section{Qual foi a maior dificuldade? (Você pode assinalar quantos quiser)}

( ) não tive dificuldades

( ) falar e entender em português

( ) interagir com as pessoas

( ) falar sobre os temas

\section{O que você mais gostou da atividade?}

( ) saber sobre as leis trabalhistas brasileira

( ) conhecer brasileiros

( ) elaborar o currículo e o portfólio

1. Escreva o que você achou e aprendeu com a atividade de hoje: 
Notas de campo- Acolher 1- 2016

1 a AULA- 21103

Muitos alunos dentro da sala, com diferentes nacionalidade e língua maternas, assim como níveis de dificuldades diferenciados. Como foi o primeiro dia, me apresentei e ensinei por meio de simulações: saudações, solicitações, cumprimentos, comandos de sala de aula e expressões úteis para manter o primeiro contato. Foi uma aula cansativa, pois muitos alunos estavam ansiosos para fazer perguntas e outros demonstravam não estarem entendo, sobretudo, os alunos de língua materna Árabe.

Uma aula com muitos alunos se torna para o professor um desafio pesado, pois a demanda de dúvidas e de falta de entendimento se torna maior, ainda mais por haver muitas nacionalidade juntas, com línguas maternas diferentes.

\section{$2^{a}$ AULA- 22/03}

Havia mais pessoas presentes que a primeira. No entanto, por ter percebido o ritmo da primeira aula, já fui mais preparada para saber como gerir toda a sala.

A primeira coisa que mudei foi o espaço da sala, antes sentávamos em círculo, por acreditar que esse espaço de círculo propõe um convívio mais interessante e democrático, mas tendo em vista a quantidade de alunos presentes, estruturei a sala de modo que eles não ficassem tão juntos e que me possibilitasse passagem para atender os estudantes que se sentaram ao fundo da sala. Deu certo a organização da sala, pude melhor atender os aprendentes.

Nesse dia houve um fato que se repetiu, um aluno sírio, não compreendendo muito a aula, se exaltou e perguntou se a aula não seria em inglês, pois eles queriam que fosse em inglês. Eu com uma postura profissional e cautelosa, disse para ele e para toda a sala que todas as aulas no NEPPE seriam em português e expliquei que assim eles poderiam aprender mais, pois iriam ter mais contato com o português (para explicar isso utilizeime do português, do francês e do inglês para tentar atender a todos na explicação).

A aula continuou, apresentei o alfabeto e depois uma música da Xuxa, que embora ser repudiada por alguns brasileiros, tenho percebido que na sala de aula para estrangeiros, essa música é sempre bem recebida. Os alunos, sobretudo, os haitianos gostaram tanto que começaram a cantar ao final da aula. Durante a apresentação do alfabeto, percebi que os alunos de origem de língua materna árabe, tinham muitas dificuldades na pronúncia das letras.

\section{Reflexão:}

Como a estrutura da sala pode influenciar

Devo ser mais serena para atender um aluno exaltado, mas ao mesmo tempo firme na condução da minha resposta?

Estar atenta as dificuldades dos alunos em consequência da influência da língua materna, pesquisa e estar em continua aprendizagem sobre outras línguas. 
$3^{\text {a }}$ AULA- 31/03

Foram menos alunos, revisei o alfabeto e levei uma atividade de fonética, que não está inserida no material didático, mas percebi a necessidade de levar essa atividade, pois alguns alunos, sobretudo os de origem de língua materna Árabe, apresentaram muitas dúvidas com a fonética do português. Foi uma tarefa extensa de fonética, mas teve bons resultados, pois os alunos começaram a distinguir e reconhecer os sons das sílabas juntas e a forma palavras.

\section{REFLEXÃO:}

Percebi que a necessidade de sistematizar momentos linguísticos e fonéticos foram importantes para dar mais segurança aos alunos.

Nessa aula, o aluno que havia se exaltado pedindo que as aulas fossem em inglês, chegou no Neppe e logo me cumprimentou. Eu dei uma atenção e um sorriso amigável para ele e acredito que isso mudou a situação, não só pelo belo sorriso, mas pela atenção dada, além disso, pedi que ele se sentasse mais a frente para que pudesse enxergar melhor e assim eu poder atende-lo, quando necessário.

Muitas vezes, alunos chegam com baixa autoestima, com uma cultura de aprender muito diferente e isso acaba por interferir nas atitudes e na própria aprendizagem. Cabe ao professor a sensibilidade para reconhecer essas situações e tentar de alguma ameniza-las e reverter esse processo. Eu tenho tentado dar atenção, olhares cuidadosos sobre os alunos para mostrar que estamos todos abertos a novas aprendizagens e que possamos juntos construir os novos saberes.

\section{$4^{\text {a AULA- 05/04 }}$}

Iniciei a aula corrigindo os exercícios sobre fonética e a cada brecha e perguntas feitas pelos alunos aproveitava para trabalhar os sentido dos vocabulários, formulando frases $\mathrm{e}$ quais os usos reais daquela frase dentro de uma situação cotidiana. Ao terminar a correção, percebi que os alunos se dedicaram a estudar a atividade sobre fonética e já conseguiam distinguir as diferentes pronuncia dadas a letra $\mathrm{R} \mathrm{e} \mathrm{S}$, dando exemplos com palavras que eles conheciam.

Teve um momento que pude trabalhar mais especificamente uma interculturalidade, perguntei qual o cantor, a cantora que eles mais gostavam do país de origem, e pedi que soletrassem o nomes dos artistas para que eu pudesse escrever os nomes na lousa. Além de mostrar interesse pela cultura dos estudantes e compartilhar gostos musicais e puder praticar com eles as letras do alfabeto do português, quando pedi para que soletrassem as palavras. Essa atividade me proporcionou conhecer novos artistas e também avaliar as dificuldades dos alunos em relação as letras do alfabeto que haviam aprendido.

Após a correção, pedi para as duas voluntárias que me acompanharam para simular uma situação de encontro.

Em seguida da apresentação, pedi para que os alunos identificassem as perguntas feitas e as respostas. Logo identificaram e fui escrevendo na lousa. Assim, pude trabalhar com eles o pronomes interrogativos. Logo após realizei uma dinâmica em que distribui papéis com pronomes interrogativos e pedi que eles formulassem perguntas para os colegas. Nessa dinâmica escolhi um a um para que levantasse, escolhesse um colega e fizesse uma pergunta. 
Essa atividade teve um bom resultado, pois os alunos praticaram perguntas cotidianas e puderam se interagir entre eles. Teve uma aluna que pedia para conversar com ela, fazer mais perguntas. Isso mostra o quanto eles estão desejos por conversar na língua-alvo.

REFLEXÃO: Aproveitar os insumos dados pelos alunos, trabalhando sempre em um viés de interculturalidade, aproveitar a bagagem cultural e de vivências que os estudantes trazem consigo.

\section{5 aULA - 12/04}

Nesta aula tivemos a presença dos/das estudantes do curso de design, foram 3 três pessoas. Eles ficaram espalhados pela sala e começaram interagir com os aprendentes.

$\mathrm{Na}$ aula retomei os pronomes interrogativos, de maneira que pedi para que eles pudessem elaborar perguntas para os nossos convidados. Todos fizeram alguma pergunta para os estudantes do design. Isso levou um bom tempo da aula, eu deixei fluir, pois todos estrangeiros e brasileiros estavam empolgados e interessados em conhecer um ao outro. Esse contato entre os aprendentes e brasileiros sempre se apresenta muito rico e é perceptível o sentimento de alegria que os aprendentes ficam ao conseguir comunicar com os brasileiros.

Após esse bate papo com os brasileiros. Um dos aprendentes, um haitiano, apresentou dúvidas sobre utilizar os verbos no presente e no passado e pediu se eu poderia escrever na lousa alguns verbos. Comecei a conjugar alguns verbos no presente do indicativo e mostrar a lógica dos verbos regulares. Fui interrompida por um aluno que pediu para que eu conjugasse também no passado. Normalmente, nesse inícios eu tinha a visão que era muita informação apresentar vários tempos verbais, no entanto, percebi que eles precisam e estão ansiosos para movimentar na língua para relatar fatos no presente e no passado, afinal de conta, a vida e os fatos passam em todos os tempos. Fiz a conjugação de alguns verbos tanto no presente quanto no passado e os aprendentes ficaram com os olhos quase imóveis de tanto que prestaram atenção, queriam copiar tudo do quadro.

Essa sistematização foi necessária pois deu um conforto aos estudantes.

Pedi que eles fizessem como tarefa de casa a conjugação dos verbos que eles acham importante para conversar com alguém.

\section{$6^{\text {a AULA- 19/04 }}$}

Recolhi a tarefa sobre os verbos, vários estudantes fizeram. Iniciei a atividade do módulo Apresentação sobre personalidades brasileiras. Perguntei quem eles conheciam de pessoas famosas e alguns não souberam dizer o nome, mas um estudante perguntou sobre a Dilma e o que acontecia no Brasil. Lembrando que este momento os noticiários e jornais falavam sobre a questão de propor impeachment para a Presidenta. Tentei explicar o que estava acontecendo e alguns fizeram algumas perguntas se eu gostava da presidenta. Não tive como não posicionar, dei um pouco da minha opinião. Percebo que nos professores somos uma referência para os estudantes, dessa forma, temos que saber como nos pronunciar para não determinar categoricamente opiniões, mas propor reflexões sobre os assuntos. Aproveite a figura da presidenta para perguntar aos alunos sobre os presidentes/tas dos países deles. Muitos estudantes, sobretudo, os haitianos, falaram sobre 
a situação do pais de origem. Notei que alguns aprendentes eram bem engajados politicamente e tentaram me explicar o que acontecia no Haiti.

Foi um momento muito enriquecedor, pois ouvi sobre a história do Haiti por um haitiano o que me possibilitou outros conhecimentos e sentimentos que não estão em livros.

Alguns apresentes reconheceram o artista Lazaro Ramos em propagandas, isso mostra que já estão começando a ter mais familiaridade com a atmosfera brasileira.

Escolheram o próximo Módulo Trabalho

\section{Dia da tarefa avaliativa - Módulo Apresentação:}

Iniciei a aula com a correção do exercícios sobre o Pelé. Os alunos tinham que fazer um texto com as informações dadas na atividade.

A maioria conseguiu produzir o texto. Além de produzir um texto, os alunos deveriam apresentar uma personalidade do país deles. Um aluno de gana iniciou a apresentação, falando sobre o Presidente de gana, esse aluno estava aparentemente nervoso para apresentar. Um outro aluno, de outra nacionalidade, tendo a percepção que o colega de sala está ansioso, se levantou e o ajudou na apresentação. Foi um até solidário e todos os demais alunos ficaram ainda mais atentos na apresentação.

Reflexão: Nessa aula percebi que os próprios aprendentes têm a consciência da dificuldade de aprender uma nova língua, reconhecendo que todos precisam de ajuda para se expressarem nessa nova língua.

Nessa mesma aula, pedi para que os alunos trabalhassem em duplas, para praticar o que eles haviam aprendido. Eles deviam sentar junto um/a colega e fazer perguntas pessoais. Reflexão: trabalhar em duplas resultou como uma dinâmica boa e produtiva e divertida, pois eles se ajudaram, além disso, permitiu promover interações e trocas culturais.

Ainda durante essa aula apresentei as profissões e ressaltei que eles deviam sempre dizer o que eles faziam no país de origem.

Reflexão: Percebi que muitos aprendentes não falavam da profissão no país de origem, não sei se porque não sabiam dizer em português ou porque não consideravam necessário por não mais estarem exercendo no novo país. Nessa aula fiz questão de ressaltar a todos e todas que é muito importante eles falem sobre as profissões que exerciam e sobre as habilidade que tinham. Destaquei que eles tinham que valorizar tudo o que eles tinham feito para que assim já fizeram.

Na sala este dia haviam:

3 professores

3 enfermeiras

1 secretária 
1a ATIVIDADE INTERCULTURAL- CHÁ \& PROSA - 25/04/2016

\author{
Notas das atividades interculturais \\ Chá\&Prosa \\ 25/04/2016
}

Tudo ocorreu dentro do planejado. Os participantes se mostraram interessados e empolgados em participar. A dinâmica foi aos poucos ganhando movimento, e o tempo estipulado para cada ciclo apresentou-se certo. Os participantes demonstraram querer ficar mais em cada ciclo.

As trocas culturais foram visíveis, pelas conversas observados durante a atividade e também pela canção tocada por jovens brasileiros ao final da atividade. Era uma canção que os aprendentes haitianos também conheciam, assim tanto brasileiros quanto haitianos cantaram a música, cada um na sua língua materna.

O sorriso estava estampado no rosto de todos e todas. Muitos trocaram contatos, ou seja, o objetivo de ampliar redes de contato foi alcançado.

\title{
Notas das atividades interculturais
}

\section{Despertar Profissional}

$31 / 05$ às $19 h$

A atividade começou com os alunos em uma grande sala, onde aconteceu uma palestra sobre as leis trabalhistas brasileira. Para ministrar essa palestra convidamos o representante do ACNUR Diego. A palestra foi proferida na língua portuguesa com tradução simultânea no inglês e francês realizada por duas voluntárias. Tivemos um número de 54 participantes, sendo 30 alunos imigrantes e refugiados. A palestra que estava com tempo determinado para acontecer em 20 minutos, se estendeu para 50 minutos, pois muitas dúvidas e questões foram colocadas pelos alunos.

As dúvidas foram:

Após a palestra fizemos um breve lanche e direcionamos os alunos para salas, onde já haviam os brasileiros a espera dos alunos para elaborarem o portfólio e o curriculum. Cada brasileiro atendeu um ou dois alunos.

Nesse momento percebemos o letramento tanto dos alunos quanto dos brasileiros, pois para muitos brasileiros o gênero portfolio foi algo novo. Isso foi percebido por meio das

questões que os brasileiros colocavam, alguns pediam ajuda em alguns tópicos, sobretudo, os dois últimos tópicos: "habilidade" e "um sentimento" Habilidade: tentar despertar, identificar no aluno 